\title{
Generation and Use of Thermal Energy in the U.S. Industrial Sector and Opportunities to Reduce its Carbon Emissions
}

Colin McMillan, Mark Ruth National Renewable Energy Laboratory

Richard Boardman, Piyush Sabharwall Michael McKellar, Shannon Bragg-Sitton Idaho National Laboratory

September 2016

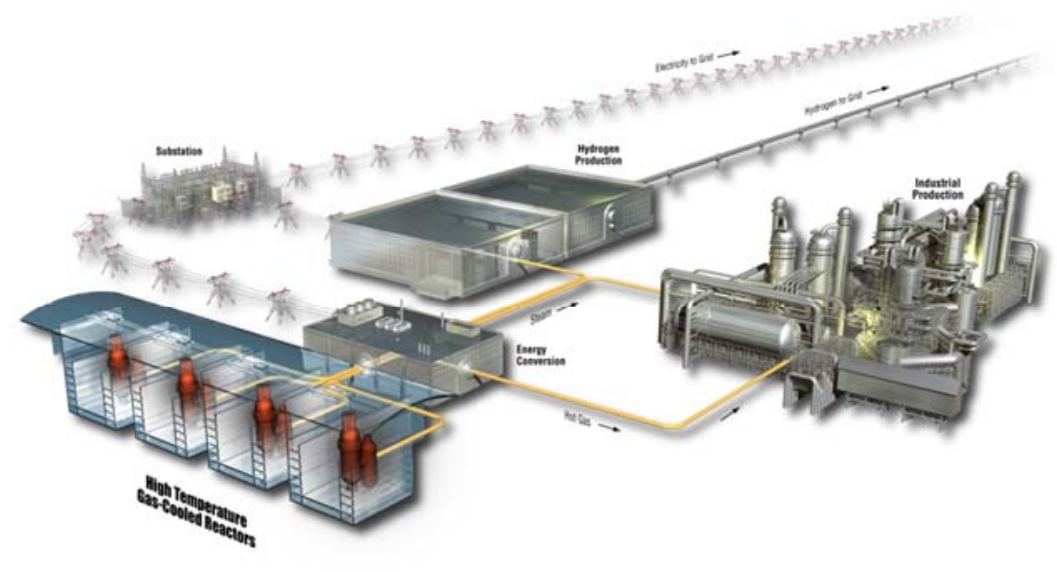




\section{DISCLAIMER}

This information was prepared as an account of work sponsored by an agency of the U.S. Government. Neither the U.S. Government nor any agency thereof, nor any of their employees, makes any warranty, expressed or implied, or assumes any legal liability or responsibility for the accuracy, completeness, or usefulness, of any information, apparatus, product, or process disclosed, or represents that its use would not infringe privately owned rights. References herein to any specific commercial product, process, or service by trade name, trade mark, manufacturer, or otherwise, does not necessarily constitute or imply its endorsement, recommendation, or favoring by the U.S. Government or any agency thereof. The views and opinions of authors expressed herein do not necessarily state or reflect those of the U.S. Government or any agency thereof. 


\title{
Generation and Use of Thermal Energy in the U.S. Industrial Sector and Opportunities to Reduce its Carbon Emissions
}

\author{
Colin McMillan, Mark Ruth \\ National Renewable Energy Laboratory \\ Richard Boardman, Piyush Sabharwall \\ Michael McKellar, Shannon Bragg-Sitton \\ Idaho National Laboratory
}

September 2016

\begin{abstract}
Idaho National Laboratory
Idaho Falls, Idaho 83415
\end{abstract}

http://www.inl.gov

Prepared for the

U.S. Department of Energy

Office of Energy Efficiency \& Renewable Energy

with the National Renewable Energy Laboratory

Under Contract No. DE-AC36-08G028308

Office of Nuclear Energy

with Idaho National Laboratory

Under DOE Idaho Operations Office

Contract DE-AC07-05ID14517 


\section{FOREWORD}

The U.S. economy is constantly evolving, especially in regard to how energy is generated and used in the electricity, buildings, industrial, and transportation sectors. These changes are being driven by economics and by environmental and energy security concerns. The electricity-sector market share of natural gas and variable-generation renewables, such as wind and solar photovoltaics (PV), continues to grow. The buildings sector is evolving to meet efficiency standards, the transportation sector is evolving to meet efficiency and renewable fuels standards, and the industrial sector is evolving to reduce emissions through efficiency improvements, advanced combined heat and power (CHP), and increased energy storage (DOE 2015a). These drivers provide investment and utilization strategies for innovative energy generation and delivery assets.

Nuclear and renewable energy sources are important to consider in the U.S. economy's evolution because both are clean, non-carbon-emitting energy sources. The Idaho National Laboratory (INL) and the National Renewable Energy Laboratory (NREL) are jointly investigating potential synergies between nuclear and renewable energy technologies. A series of workshops since 2011 have brought together experts and stakeholders in both areas to identify collaboration opportunities and to develop research plans to analyze and evaluate the cost-benefits and technical development needs of nuclear renewable energy beyond the electrical power market. Workshop participants identified nuclear-renewable hybrid energy systems (N-R HESs) as one of the potential opportunities and recommended investigating whether N-R HESs could both generate dispatchable electricity without carbon emissions and provide clean energy to industrial processes. They also recommended analyzing the potential for N-R HESs to provide dispatchable capacity to the grid and to investigate whether real inertia provided by thermal power cycles within N-R HESs provides value to the grid.

Several categories of N-R HESs have been identified. Tightly coupled N-R HESs are co-located, directly integrated, and co-controlled behind the grid (i.e., they have a single connection to the grid). Thermally coupled N-R HESs have an integrated thermal connection and are co-controlled but may have multiple electrical connections to the grid and subsystems may not be co-located. Loosely coupled, electricity-only, N-R HESs only have electrical interfaces and subsystems that can be located separately with multiple connections to the grid but they are co-controlled so a single management entity dispatches the energy and services they provide to the grid.

This report is one in a series of reports that INL and NREL are publishing that address the technical and economic aspects of N-R HESs. Previous reports focused on tightly coupled N-R HESs. Two N-R HES scenarios were initially analyzed by INL to evaluate their dynamic performance characteristics (Garcia 2015). NREL subsequently conducted an assessment of optimal economic configurations and operation of similar N-R HESs (Ruth et al. 2016a). These scenarios are based on a future condition when a significant fraction of power generation is being produced by wind or PV and a new small/modular nuclear power plant that apportions heat between power production and a heat user is added to the grid. The first scenario involves the production of methanol from natural gas with nuclear energy shifting between methanol production and power production that ramps up and down, corresponding to wind power generation and grid demand dynamics. The second scenario involves operation of a brackish 
water desalination plant when the combination of nuclear and solar power generation exceeds grid demand.

The joint analyses by INL and NREL found that nuclear plants can effectively modulate heat between power production and heat use by an industrial consumer. The analyses by NREL indicate the optimal financial per forma occurs when the nuclear reactor is mainly supplying heat to industry. The nuclear reactor may switch to power generation if capacity payments for power production are adequate. These outcomes demonstrate that nuclear and renewable energy can fulfill power generation and thermal duties of the grid and industrial heat users in a complementary manner, but hybridization will depend on the future cost of natural gas power production, and clean energy investment and production incentives.

This report quantifies greenhouse gas $(\mathrm{GHG})$ emissions from the industrial sector and identifies opportunities for non-GHG-emitting thermal energy sources to replace the most significant GHG-emitting U.S. industries based on targeted, process-level analysis of industrial heat requirements. The intent is to provide a basis for projecting opportunities for clean energy use. This provides a prospectus for small modular nuclear reactors (including N-R HES), solar industrial process heat, and geothermal energy. 


\section{ACKNOWLEDGEMENTS}

The authors thank the Office for Advanced Reactor Technology within the U.S. Department of Energy's (DOE's) office of Nuclear Energy (NE) and the Office of Strategic Programs within DOE's office of Energy Efficiency and Renewable Energy (EERE) for their support of this analysis and report. The authors also thank those who originated and developed the concept of nuclear-renewable hybrid energy systems including Charles Forsberg of the Massachusetts Institute of Technology (MIT); Humberto Garcia, and Steven Aumeier of INL; and Owen Zinaman of NREL. And we acknowledge and thank the following individuals for their reviews and comments: Steve Capanna, Ookie Ma, Paul Spitsen, and Brian Walker (EERE); Carl Sink (NE); John Agan (DOE's office of Energy Policy and Systems Analysis); Carl Stoots (INL); Doug Arent of the Joint Institute for Strategic Energy Analysis (JISEA); and Gian Porro, Parthiv Kurup, and Kevin McCabe (NREL); and John Agan (EPSA).

This work was supported by the DOE under Contract No. DE-AC36-08GO28308 with the National Renewable Energy Laboratory. Funding was provided by DOE EERE's Office of Strategic Programs and for the U.S. Department of Energy Office of Nuclear Energy under DOE Idaho Operations Office Contract DE-AC07-05ID14517. 


\section{EXECUTIVE SUMMARY}

The industrial sector was the third-largest source of direct ${ }^{1}$ U.S. greenhouse gas (GHG) emissions in 2014, behind electricity generation and transportation, and accounted for roughly $20 \%$ of total emissions (EPA 2016). The Energy Information Administration (EIA) projects that total U.S. energy consumption will grow to about 108 exajoules $\left(1 \mathrm{EJ}=10^{18} \mathrm{~J}\right)$ or 102 quads ( 1 quad $=10^{15}$ British thermal units) in 2025, with nearly all of the growth coming from the industrial sector (DOE, 2015). Energy consumption in the industrial sector is forecast to increase to $39.5 \mathrm{EJ}$ (37.4 quads) - a $22 \%$ increase, exceeding $36 \%$ of total energy consumption in the United States. Therefore, it is imperative that industrial GHG emissions be considered in any strategy intent on achieving deep decarbonization of the energy sector as a whole. Moreover, it is important to note that unlike the transportation sector and electrical grid, energy use by industry often involves direct conversion of primary energy sources to thermal and electrical energy at the point of consumption. The heterogeneity and variations in scale of U.S. industry and the complexity of modern industrial firms' global supply chains are among the sector's unique challenges to minimizing its GHG emissions. A combination of varied strategies - such as energy efficiency, material efficiency, and switching to low-carbon fuels - can help reduce absolute industrial GHG emissions (Fischedick et al. 2014a).

This report provides a complement to process-efficiency improvement to consider how clean energy delivery and use by industry could reduce GHG emissions. Specifically, it considers the possibility of replacing fossil-fuel combustion in industry with nuclear (specifically small modular reactors or SMRs), concentrating solar (referred to herein as solar industrial process heat or SIPH), and geothermal energy sources. The possibility of applying electrical heating and greater use of hydrogen is also considered. About $58 \%$ of U.S. industrial direct GHG emissions are the result of fuel combustion (EPA 2016) to produce hot gases and steam for process heating, process reactions, and process evaporation, concentration, and drying.

Development of effective GHG mitigation strategies requires a detailed understanding of the types of industries and their energy-use patterns and associated emissions. This has recently been made possible by the U.S. Environmental Protection Agency (EPA) Greenhouse Gas Reporting Program (GHGRP). Under the Mandatory Reporting of Greenhouse Gases Rule, facilities with annual direct emissions greater than or equal to 25,000 metric tons carbon dioxide-equivalent $\left(\mathrm{MTCO}_{2} \mathrm{e}\right.$ ) are required to report to the EPA (Part 98-Mandatory Greenhouse Gas Reporting 2016). Over 8,000 facilities representing nine industry sectors ${ }^{2}$ reported direct emissions of 3,200 million $\mathrm{MTCO}_{2} \mathrm{e}\left(\mathrm{MMTCO}_{2} \mathrm{e}\right)$, or nearly half of U.S. total GHG emissions, for the 2014 reporting year (U.S. Environmental Protection Agency 2016).

In this study, we used the GHGRP-reported emissions data and EPA GHG emissions factors to calculate facility-level thermal energy demands. Fourteen key industries with the relatively highest annual GHG emissions were selected for assessment of their emission characteristics and thermal heat duties. Within these industries, representative plants were selected to determine how clean heat from SMRs, SIPH, and geothermal sources could be used.

\footnotetext{
${ }^{1}$ Direct emissions are the result of activities that occur on-site at a facility (U.S. EPA 2015).

${ }^{2}$ The EPA identifies these nine industry sectors as power plants, petroleum and natural gas systems, refineries, chemicals, waste, metals, minerals, pulp and paper, and "other" (U.S. EPA 2016b).
} 
The GHGRP data allowed further disaggregation of thermal energy use, enabling analysis by fuel type, combustion-unit type, and end use for the 14 industries. The target industries are listed in declining order of GHG emissions in Table ES-1, along with potential alternative heat supplies identified in this report. Note that this table represents an initial selection based only on a matching of process-heat temperature and does not consider all technical and non-technical characteristic of each alternative heat supply. Additional technical characteristics and considerations are provided in the main body of the report.

The common feature of the target industries is that they convert raw materials into energy services by means of physical and chemical changes. These changes generally require thermal energy to affect solids and liquids heat-up, melting, and evaporation, and to heat up reactants to initiate molecular bond-breaking and to sustain the propagation of chemical reactions. Heat demands range from low-temperature steam $\left(50^{\circ} \mathrm{C}, 0.7\right.$ megapascal $\left.(\mathrm{MPa})\right)$ for steeping in corn wet-milling to high-temperature operations up to $2,200^{\circ} \mathrm{C}$ for electric arc furnaces. The scale of heat demand for the average facility ranges from $0.016 \mathrm{TJ}$ per day (15 MMBtu/day; or $0.2 \mathrm{MW}$ ) for electrochemical production of 1,330 tonnes per day chlorine to $26 \mathrm{TJ} /$ day $(25,000 \mathrm{MMBtu}$; or $300 \mathrm{MW}$ ) for 5,273 tonnes per day of potash, soda, or borate mining and processing.

Several technical challenges and opportunities to application of clean energy sources for industrial heat users were identified and are discussed in this report, including:

- Quality of heat required by the user (or temperature of the working fluid)

- Industry process heat-transfer modes

- Scale of heat source versus heat user demand which may be mitigated by selecting the appropriate source or by industrial clustering (viz., an energy park)

- Transport requirements between the heat source and industrial process-unit operations which involves distance and the materials needed for that transport

- Thermal energy storage needs and options

- Hybrid heat/electricity production

- Electrification of heating processes

- Hydrogen production and use as an intermediate energy source 
Table ES-1. Summary of Potential Alternative Heat Supplies by Target Industry $\left(T J=\right.$ terajoule $\left.=10^{12} \mathrm{~J}\right)$

\begin{tabular}{|c|c|c|c|c|c|c|c|c|}
\hline $\begin{array}{l}\text { Target } \\
\text { Industry }\end{array}$ & $\begin{array}{l}\text { Number of } \\
\text { GHGRP- } \\
\text { Reporting } \\
\text { Plants in } \\
2014\end{array}$ & $\begin{array}{l}\text { Average Size } \\
\text { of Plant } \\
\text { (Production } \\
\text { Rate) } \\
\text { (tonnes/day) }\end{array}$ & $\begin{array}{c}\text { Total } \\
\text { Reported } \\
\mathrm{CO}_{2} \\
\text { Emissions } \\
\text { (MM tonnes) }\end{array}$ & $\begin{array}{l}\text { Fraction of } \\
\text { Industrial } \\
\text { Sector GHG } \\
\text { Emissions } \\
(\%)^{*}\end{array}$ & $\begin{array}{l}\text { Industry Process- } \\
\text { Heat Type / Purpose }\end{array}$ & $\begin{array}{l}\text { Average Plant } \\
\text { Heat Use in } \\
\text { TJ/day } \\
\text { (MMBtu/day) }\end{array}$ & $\begin{array}{c}\text { Process-Heat } \\
\text { Temperature } \\
\left({ }^{\circ} \mathrm{C}\right)\end{array}$ & $\begin{array}{c}\text { Potential } \\
\text { Alternative Heat } \\
\text { Supply }\end{array}$ \\
\hline $\begin{array}{l}\text { Petroleum } \\
\text { Refineries }\end{array}$ & \multirow{4}{*}{141} & & \multirow{4}{*}{124} & \multirow{4}{*}{8} & \multirow{4}{*}{$\begin{array}{l}\text { Combustion gases / } \\
\text { Atmospheric crude } \\
\text { fractionator and } \\
\text { heavy naphtha } \\
\text { reformer }\end{array}$} & \multirow{4}{*}{$8.23(7,800)$} & \multirow{4}{*}{600} & \multirow{4}{*}{$\begin{array}{l}\text { SIPH, SMR } \\
\text { (HTGR) }\end{array}$} \\
\hline Gasoline & & $33,828 \mathrm{bpd}$ & & & & & & \\
\hline Diesel & & $12,747 \mathrm{bpd}$ & & & & & & \\
\hline Kerosene & & $6,755 \mathrm{bpd}$ & & & & & & \\
\hline \multirow{3}{*}{$\begin{array}{l}\text { Iron and Steel } \\
\text { Mills }\end{array}$} & \multirow{3}{*}{115} & \multirow{3}{*}{603} & \multirow{3}{*}{51} & \multirow{3}{*}{3} & $\begin{array}{l}\text { Combustion gases / } \\
\text { coke production }\end{array}$ & \multirow{3}{*}{$2.42(2,290)$} & 1,100 & $\begin{array}{l}\text { Hydrogen reducing } \\
\text { agent }\end{array}$ \\
\hline & & & & & $\begin{array}{l}\text { Combustion gases / } \\
\text { steel production }\end{array}$ & & 1,700 & Hydrogen \\
\hline & & & & & $\begin{array}{l}\text { Electricity / steel } \\
\text { production }\end{array}$ & & 2,200 & SIPH (CSP), SMR \\
\hline \multirow[t]{2}{*}{ Paper Mills } & \multirow[t]{2}{*}{116} & \multirow[t]{2}{*}{1,723} & \multirow[t]{2}{*}{32} & \multirow[t]{2}{*}{2} & $\begin{array}{l}\text { Steam / stock } \\
\text { preparation }\end{array}$ & \multirow{4}{*}{$21.1(20,000)$} & 150 & SMR, SIPH \\
\hline & & & & & Steam / drying & & 177 & SMR, SIPH \\
\hline \multirow{2}{*}{$\begin{array}{l}\text { Paperboard } \\
\text { Mills }\end{array}$} & \multirow[t]{2}{*}{73} & \multirow[t]{2}{*}{4,427} & \multirow[t]{2}{*}{24} & \multirow[t]{2}{*}{1.5} & $\begin{array}{l}\text { Steam / stock } \\
\text { preparation }\end{array}$ & & 150 & SMR, SIPH, \\
\hline & & & & & Steam / drying & & 177 & SMR, SIPH \\
\hline \multirow{3}{*}{ Pulp Mills } & \multirow{3}{*}{30} & \multirow{3}{*}{474} & \multirow{3}{*}{12} & \multirow{3}{*}{0.7} & $\begin{array}{l}\text { Combustion gases / } \\
\text { electricity production }\end{array}$ & $0.67(640)$ & 500 & SIPH, SMR \\
\hline & & & & & $\begin{array}{l}\text { Steam / wood } \\
\text { digesting, bleaching, } \\
\text { evaporation, chemical } \\
\text { preparation }\end{array}$ & $1.15(1,090)$ & 200 & SMR, SIPH \\
\hline & & & & & $\begin{array}{l}\text { Steam / evaporation, } \\
\text { chemical preparation }\end{array}$ & $2.56(2,430)$ & 150 & SMR, SIPH \\
\hline
\end{tabular}




\begin{tabular}{|c|c|c|c|c|c|c|c|c|}
\hline $\begin{array}{l}\text { Target } \\
\text { Industry }\end{array}$ & $\begin{array}{l}\text { Number of } \\
\text { GHGRP- } \\
\text { Reporting } \\
\text { Plants in } \\
2014\end{array}$ & $\begin{array}{c}\text { Average Size } \\
\text { of Plant } \\
\text { (Production } \\
\text { Rate) } \\
\text { (tonnes/day) }\end{array}$ & $\begin{array}{c}\text { Total } \\
\text { Reported } \\
\mathrm{CO}_{2} \\
\text { Emissions } \\
\text { (MM tonnes) }\end{array}$ & $\begin{array}{l}\text { Fraction of } \\
\text { Industrial } \\
\text { Sector GHG } \\
\text { Emissions } \\
(\%)^{*}\end{array}$ & $\begin{array}{l}\text { Industry Process- } \\
\text { Heat Type / Purpose }\end{array}$ & $\begin{array}{l}\text { Average Plant } \\
\text { Heat Use in } \\
\text { TJ/day } \\
\text { (MMBtu/day) }\end{array}$ & $\begin{array}{l}\text { Process-Heat } \\
\text { Temperature } \\
\left({ }^{\circ} \mathrm{C}\right)\end{array}$ & $\begin{array}{c}\text { Potential } \\
\text { Alternative Heat } \\
\text { Supply }\end{array}$ \\
\hline $\begin{array}{l}\text { All Other } \\
\text { Basic } \\
\text { Chemical } \\
\text { Manufacturing }\end{array}$ & 85 & 2,702 & 21 & 1.3 & $\begin{array}{l}\text { Combustion gases / } \\
\text { primary reformer; } \\
\text { steam / methanol } \\
\text { distillation }\end{array}$ & $12.9(12,200)$ & 900 & $\begin{array}{l}\text { Smaller industries } \\
\text { not addressed in } \\
\text { this study }\end{array}$ \\
\hline \multirow{3}{*}{$\begin{array}{l}\text { Ethyl Alcohol } \\
\text { Manufacturing }\end{array}$} & \multirow{3}{*}{168} & \multirow{3}{*}{63.7} & \multirow{3}{*}{18} & \multirow{3}{*}{1.1} & $\begin{array}{l}\text { Combustion gases for } \\
\text { steam/ pretreatment } \\
\text { and conditioning }\end{array}$ & \multirow{3}{*}{$1.76(1,670)$} & 266 & SMR, SIPH \\
\hline & & & & & Steam / distillation & & 233 & SMR, SIPH \\
\hline & & & & & $\begin{array}{l}\text { Steam / electricity } \\
\text { production }\end{array}$ & & 454 & SMR \\
\hline $\begin{array}{l}\text { Petrochemical } \\
\text { Manufacturing }\end{array}$ & 35 & 2,665 & 16 & 1 & $\begin{array}{l}\text { Combustion gases / } \\
\text { cracking furnace }\end{array}$ & $2.37(2,250)$ & 875 & Hydrogen \\
\hline $\begin{array}{l}\text { Alkalies and } \\
\text { Chlorine } \\
\text { Manufacturing }\end{array}$ & \multirow{3}{*}{11} & & \multirow{3}{*}{13} & \multirow{3}{*}{0.8} & \multirow{3}{*}{ Steam / drying } & \multirow{3}{*}{$4.26(4,040)$} & \multirow{3}{*}{177} & \multirow{3}{*}{ SMR, SIPH } \\
\hline Chlorine & & 1,330 & & & & & & \\
\hline $\begin{array}{l}\text { Sodium } \\
\text { Hydroxide }\end{array}$ & & 1,162 & & & & & & \\
\hline $\begin{array}{l}\text { Nitrogenous } \\
\text { Fertilizer } \\
\text { Manufacturing }\end{array}$ & 30 & 757 & 8 & 0.5 & $\begin{array}{l}\text { Combustion gases/ } \\
\text { primary steam } \\
\text { reforming }\end{array}$ & $7.03(6,660)$ & 850 & SMR \\
\hline Wet Corn & \multirow{4}{*}{24} & & \multirow{4}{*}{18} & \multirow{4}{*}{1.1} & Steam / steeping & \multirow{4}{*}{$8.06(7,640)$} & 50 & $\begin{array}{l}\text { SMR, SIPH, } \\
\text { geothermal }\end{array}$ \\
\hline Starch & & 1,461 & & & \multirow{3}{*}{ Steam / drying } & & \multirow{3}{*}{177} & \multirow{3}{*}{ SMR, SIPH, } \\
\hline $\begin{array}{l}\text { Corn Gluten } \\
\text { Feed }\end{array}$ & & 593 & & & & & & \\
\hline $\begin{array}{c}\text { Corn Gluten } \\
\text { Meal }\end{array}$ & & 137 & & & & & & \\
\hline
\end{tabular}




\begin{tabular}{|c|c|c|c|c|c|c|c|c|}
\hline $\begin{array}{l}\text { Target } \\
\text { Industry }\end{array}$ & $\begin{array}{l}\text { Number of } \\
\text { GHGRP- } \\
\text { Reporting } \\
\text { Plants in } \\
2014\end{array}$ & $\begin{array}{c}\text { Average Size } \\
\text { of Plant } \\
\text { (Production } \\
\text { Rate) } \\
\text { (tonnes/day) }\end{array}$ & $\begin{array}{c}\text { Total } \\
\text { Reported } \\
\mathrm{CO}_{2} \\
\text { Emissions } \\
\text { (MM tonnes) }\end{array}$ & $\begin{array}{c}\text { Fraction of } \\
\text { Industrial } \\
\text { Sector GHG } \\
\text { Emissions } \\
(\%)^{*}\end{array}$ & $\begin{array}{l}\text { Industry Process- } \\
\text { Heat Type / Purpose }\end{array}$ & $\begin{array}{l}\text { Average Plant } \\
\text { Heat Use in } \\
\text { TJ/day } \\
\text { (MMBtu/day) }\end{array}$ & $\begin{array}{c}\text { Process-Heat } \\
\text { Temperature } \\
\left({ }^{\circ} \mathrm{C}\right)\end{array}$ & $\begin{array}{c}\text { Potential } \\
\text { Alternative Heat } \\
\text { Supply }\end{array}$ \\
\hline Corn Oil & & 92 & & & & & & \\
\hline $\begin{array}{l}\text { Lime and } \\
\text { Cement }\end{array}$ & \multirow{3}{*}{49} & & \multirow{3}{*}{10} & \multirow{3}{*}{0.6} & \multirow{3}{*}{$\begin{array}{l}\text { Combustion gases / } \\
\text { heating kiln }\end{array}$} & \multirow{3}{*}{$12.45(11,800)$} & \multirow{3}{*}{$1,200-1,500$} & \multirow{3}{*}{$\begin{array}{l}\text { Hydrogen flame } \\
\text { enrichment }\end{array}$} \\
\hline Lime & & 507 & & & & & & \\
\hline Cement & & 2,000 & & & & & & \\
\hline $\begin{array}{l}\text { Potash, Soda, } \\
\text { and Borate } \\
\text { Mining }\end{array}$ & 11 & 5,273 & 6 & 0.4 & $\begin{array}{l}\text { Steam / calciner, } \\
\text { crystallizer, and dryer }\end{array}$ & $26(25,000)$ & 300 & SMR, SIPH \\
\hline
\end{tabular}

* Includes $\mathrm{CO}_{2}$ from biomass combustion

* SMR temperatures up to $850^{\circ} \mathrm{C}$, SIPH temperatures up to $300^{\circ} \mathrm{C}$, Geothermal heat supply up to $150^{\circ} \mathrm{C}$ 
Our calculations indicate that the largest end uses of combustion energy in 2014 were combined heat and power (CHP) and/or cogeneration (37\% of calculated energy use), conventional boiler use $(32 \%)$, and process heating (24\%). Natural gas was the most-used fuel by the target industries, accounting for $44 \%$ of calculated combustion energy use. Data reported for combustion-unit type had limited utility because the majority of fuel combustion was designated as "other combustion source."

The geographical distribution of these industries is illustrated in Figure ES-1. Not surprisingly, the ethanol production and pulp and paper industries are situated within the agriculture belts of the country. Large refineries are located near estuaries and oil production fields (i.e., Gulf shores, Great Lakes, ocean inland bays). The majority of petroleum-based chemical industries are located in proximity to the petroleum refineries. With the growth of metals recycling, about onehalf of the steel industry is spread throughout the United States. The other half of steel making is from iron ore and is mainly located around the Great Lakes and Southeast Regions. Minerals and fertilizer production is scattered around the country where the minerals are located.

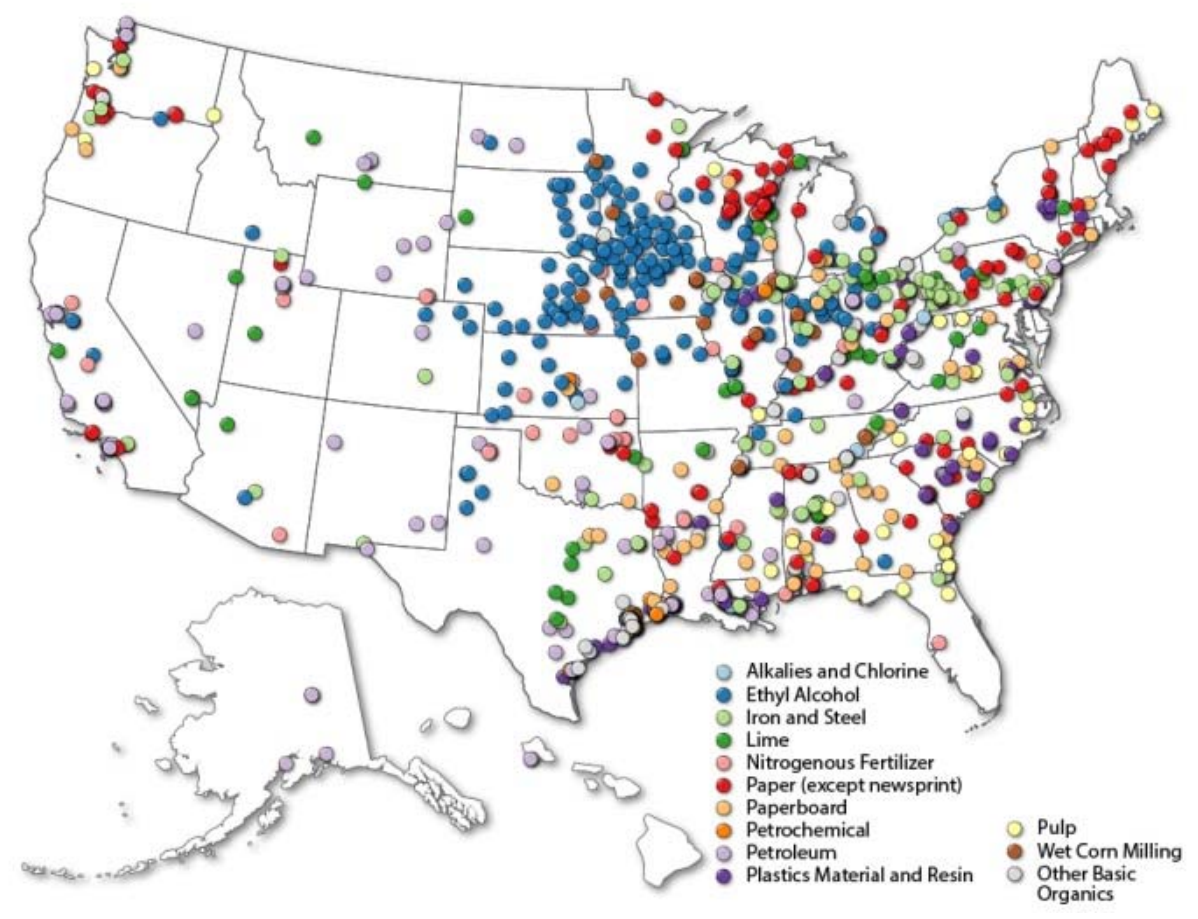

Figure ES-1. Geographical location of industries evaluated for alternative clean heat provisions

The summary of findings includes the following highlights:

1. Fourteen industries were selected for process-level thermal analysis. In 2014, 960 plants representing these industries reported emissions under the GHGRP. They constitute less than $0.5 \%$ of all U.S. manufacturing facilities, but are responsible for nearly $25 \%$ of U.S. GHG inventory industrial-sector emissions, which equates to $5 \%$ of U.S. total emissions 
in 2014. Most of the remaining $75 \%$ of industrial GHG emissions is therefore tied to smaller facilities that fall under the EPA reporting limits for large GHG emitters.

2. Calculated combustion energy use in 2014 by the 14 target industries was 5,824 petajoules $\left(1 \mathrm{PJ}=10^{15} \mathrm{~J}\right)$ or 5.520 quads - nearly $50 \%$ of 2010 manufacturing combustion energy use estimated by the EIA Manufacturing Energy Consumption Survey (MECS).

3. Within those 14 industries, CHP and conventional steam boilers account for about $70 \%$ of the heat loads. Those and other fossil-fired heating systems could be substituted by clean heat sources generating steam, hot gas, and heating other heat-transfer media. Options for clean heat sources include emerging SMRs, SIPH, and geothermal sources, as their scales are applicable to individual industry needs.

4. Most process heating within these 14 industries is accomplished with steam jackets, heating coils, and indirect heat exchangers that transfer heat from a hot gas (generally combustion gases) to the process reactor. Clean heating systems could replace the combustion gas systems by using heat circulation systems such as those described in this report.

5. Several industrial heat users, such as oil refineries, pulp/paper manufacturing, methanol, fertilizer plants, corn wet milling plants, and some inorganic mineral plants, have duties in excess of $10 \mathrm{TJ} /$ day $(9,500 \mathrm{MMBtu} ; 120 \mathrm{MWt})$. SMR technologies are expected to be well-matched to this scale of demand.

6. SIPH applications can potentially supply heat to the majority of the industrial applications analyzed here. Specific examples include chlorine/alkali plants, ethylene and other chemical production plants, and food processing plants. Currently, all of the major concentrating solar projects in the U.S. are in the Southwest, with a few in Florida and Hawaii. Therefore, SIPH systems for industrial heating are likely to be impacted by the effectiveness of insolation at the location of the industry. Additionally, the footprint of available space for concentrating solar energy systems and energy storage systems are other technical considerations.

7. Geothermal energy could provide thermal energy to food processing plants and to plants that use lower temperature heat to concentrate and/or dry process feedstocks and products. Corn milling and drying and ethyl alcohol production are two examples. Current geothermal energy production techniques usually provide lower temperature energy (typically ranging from $50-150^{\circ} \mathrm{C}$ ) than is required by industry. Enhanced geothermal systems that could achieve higher temperature output are currently being developed.

8. The design of heat transport from SMR and SIPH sources to the industrial user may be optimized with a heat circulation system that uses a liquid heat transfer media — such as a molten salt or Dowtherm ${ }^{\mathrm{TM}}$ — to deliver thermal energy over relatively long distances. Heat transfer to a hot gas or steam loop may then optimally interface with the heating coils or boiler tubes that are used in most industrial processes. 
9. Heat recuperation and temperature boosting are important thermal energy management concepts that may benefit SMR, SIPH, and geothermal energy sources. High temperature heat pump concepts, including adsorption/desorption chemical cycles, can help boost the temperature of heating media.

10. Hybrid thermal/electricity generation may help balance hourly, daily, and/or seasonal electrical cycles. Seasonal heat load opportunities include food processing and/or dehydration, conversion of biomass to intermediate products by drying, torrefaction, pyrolysis oil production and stabilization, ethanol production, hydrogen production, industry waste-water cleanup or brackish-water desalination, and pumped hydro and compressed-air storage.

11. Intermittent or batch plant operations may require thermal energy storage systems that match clean energy delivery with thermal load schedules.

12. Electrification of industry warrants further consideration. Thermal energy storage concepts such as those being developed for concentrating solar systems may help coordinate grid profiles with industry heat use profiles. Direct electrical heating is technically feasible, but could add to grid response dynamics and challenges.

13. Hydrogen production for use as a substitute fuel gas by industry could reduce industry GHG emissions. Hydrogen can also replace carbon that is used as a reducing agent in steel manufacturing. Hydrogen that is produced by water splitting would provide carbonfree hydrogen for these uses.

14. This report identified opportunities to use approximately $403,150-\mathrm{MW}_{\mathrm{t}}$, nuclear reactor modules, supplying $1,900 \mathrm{PJ} / \mathrm{yr}$ of heat ranging up to $850^{\circ} \mathrm{C}$. Petroleum refineries use 9,130 metric tonnes/day of hydrogen. Substitution of hydrogen for coke in the U.S. steel production would use an additional 6,690 metric tonnes/day of hydrogen. This could be provided by high temperature steam electrolysis plants that use electricity and heat supplied by one of the clean energy sources. Assuming light-water SMR units with a 150 MWt capacity are used, 309 SMR modules would be necessary to produce all of the refinery merchant hydrogen demand and 226 SMR modules would be necessary to produce merchant hydrogen for the steel industry. To supply heat to industry and hydrogen to both refineries and steel production, $939 \mathrm{SMRs}$, rated at $150 \mathrm{MW}_{\mathrm{t}}$, would be necessary. More would be needed if industries with a heat duty under $150 \mathrm{MW}_{\mathrm{t}}$ are located in a cluster. The potential number of SMRs that could be built may be limited to siting restrictions and licensing restrictions.

15. SIPH and geothermal energy systems are theoretically scalable to any load. Commercial systems for SIPH range from $100 \mathrm{~kW}_{\mathrm{t}}$ for small industries to approximately $1,000 \mathrm{MW}_{\mathrm{t}}$ for concentrating solar power (CSP) systems. SIPH could therefore supply up to 2000 $\mathrm{PJ} / \mathrm{yr}$ to the 14 target industries identified in this report before considering practical temperature and spatial constraints. By comparison, geothermal systems that can provide a heat supply media at $150^{\circ} \mathrm{C}$ can provide up to $180 \mathrm{PJ} / \mathrm{yr}$ to those target industries. SIPH and geothermal energy may be impractical in some locations due to resource quality. 
Analysis opportunities related to these observations and finding are listed in this report.

Recommendations include additional nuclear-renewable hybrid energy system case studies, assessment of industry electrification options, evaluation of thermal energy storage buffers and heat-transfer systems, detailed evaluation of SIHP and geothermal energy resource potential for industrial heating, and technical/economic assessment of the benefits of hydrogen production for industrial use. 


\section{CONTENTS}

FOREWORD

ACKNOWLEDGEMENTS

$\mathrm{V}$

EXECUTIVE SUMMARY vii

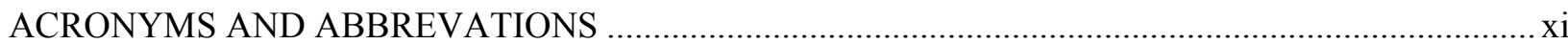

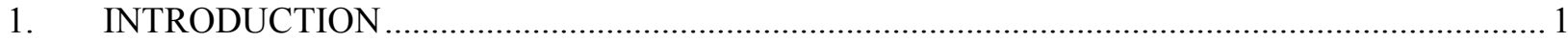

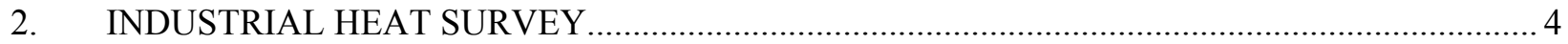

2.1 Selecting Industries for Detailed Energy Analysis .................................................... 4

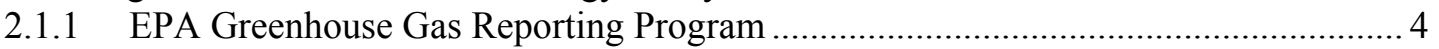

2.1.2 Identifying Industrial Energy Survey Target Industries.......................................... 5

2.2 Combustion Energy Use Analysis of Target Industries ...................................................... 9

2.2.1 Calculating Thermal Energy Use from EPA Greenhouse Gas Reporting

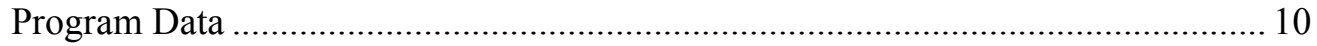

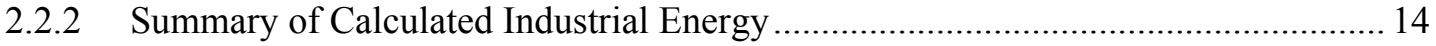

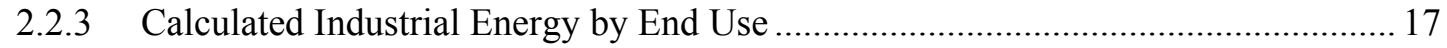

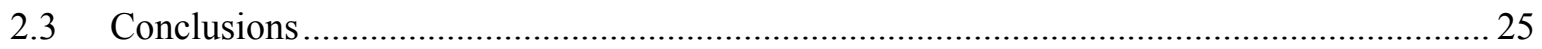

3. APPLICATION OF THERMAL ENERGY IN INDUSTRY …..................................................... 26

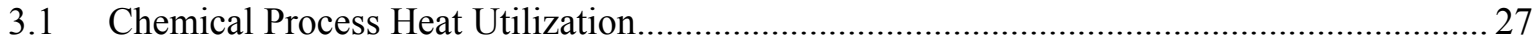

3.2 Assessment of Industry Thermal Energy Use .................................................................. 29

3.3 Petroleum and Coal Products Manufacturing - Petroleum Refineries................................. 34

3.4 Primary Metal Manufacturing - Iron and Steel Mills ...................................................... 35

3.5 Paper Manufacturing - Paper, Paperboard, and Pulp Mills ............................................... 36

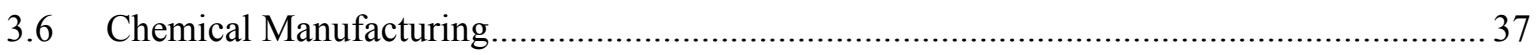

3.6.1 All Other Basic Organic Chemical Manufacturing (Methanol) ……........................ 37

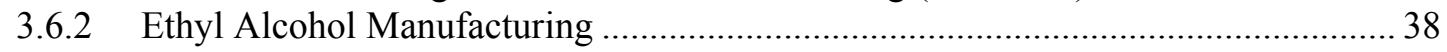

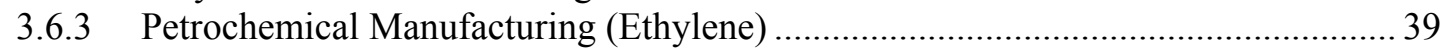

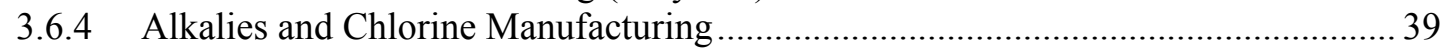

3.6.5 Nitrogenous Fertilizer Manufacturing (Ammonia and Derivatives) ......................... 40

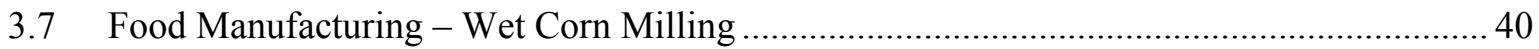

3.8 Nonmetallic Mineral Product Manufacturing - Lime and Cement Manufacturing .............. 41

3.9 Mining (Except Oil and Gas) - Soda Ash, Potash, and Borate Mineral Mining .................. 41

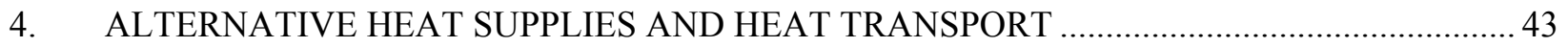

$4.1 \quad$ Heat Matching with Very Low Carbon Heat Generators................................................... 44

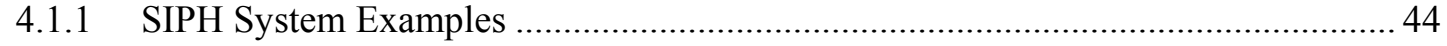

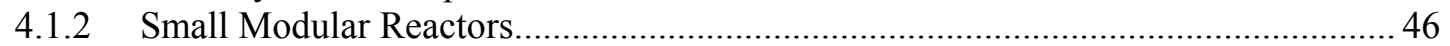

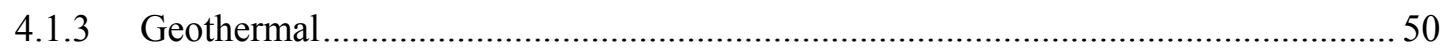

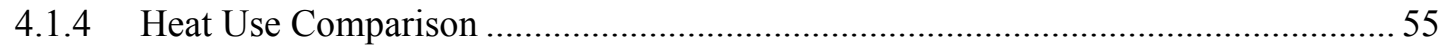

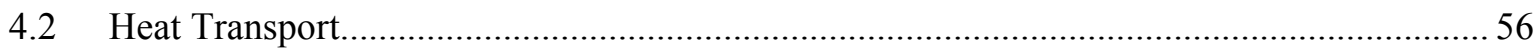

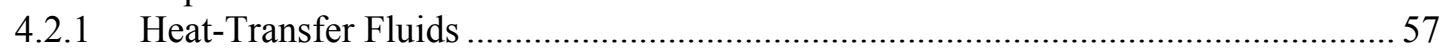

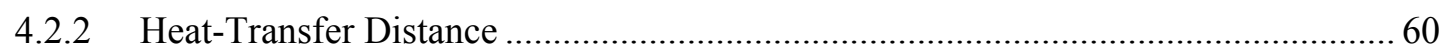




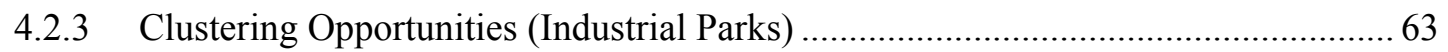

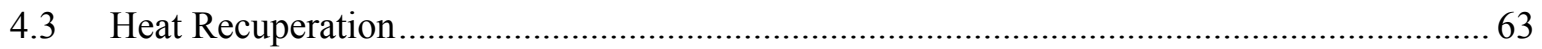

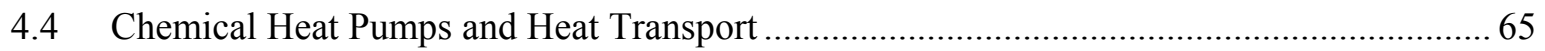

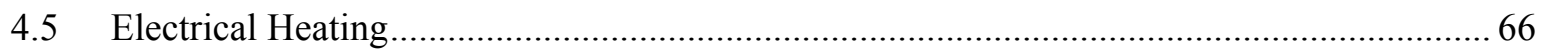

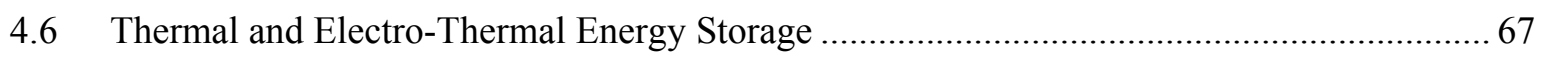

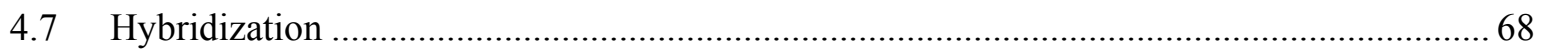

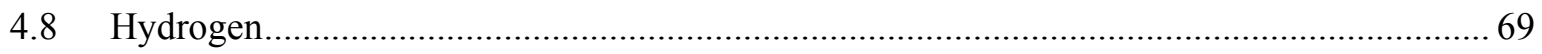

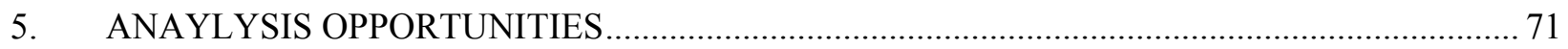

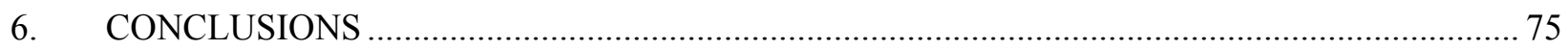

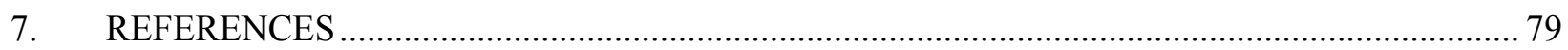

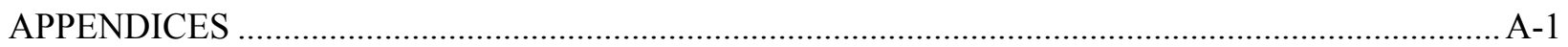

Appendix A Description of Target Industries ....................................................... A-2

Appendix B Calculated Energy by End Use and Target Industry in 2014 ....................... A-4

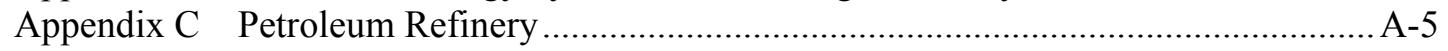

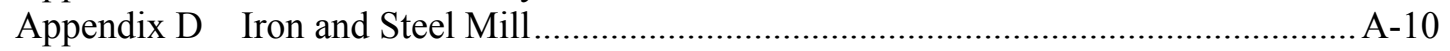

Appendix E Paper and Paperboard Mills ............................................................... A-16

Appendix F Pulp Process .................................................................................

Appendix G All Other Basic Organic Chemical Manufacturing (Methanol

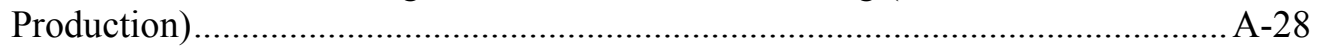

Appendix H Ethyl Alcohol Production within Biorefinery ........................................ A-32

Appendix I Plastics Material and Resin Manufacturing ............................................... A-37

Appendix J Petrochemical Manufacturing (Ethylene Production)................................... A-38

Appendix K Alkalies and Chlorine Manufacturing ….................................................. A-42

Appendix L Nitrogenous Fertilizer Manufacturing (Ammonia Production) .................. A-46

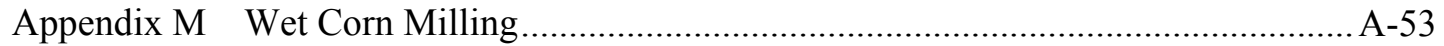

Appendix N Lime and Cement Manufacturing........................................................

Appendix O Potash, Soda, and Borate Mining ............................................................ A-66

\section{FIGURES}

Figure ES-1. Geographical location of industries evaluated for alternative clean heat provisions...............i

Figure 1. Trends in industrial GHG emissions for the United States and the world................................. 2

Figure 2. Target industry fraction of industrial sector total GHG emissions for 2014 ............................. 7

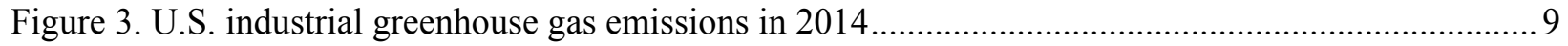

Figure 4. Generalized calculation of facility combustion energy use from GHGRP-reported

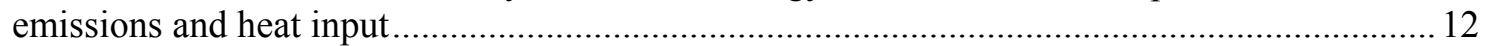

Figure 5. Manufacturing fuel-combustion energy as reported by EIA MECS and calculated from

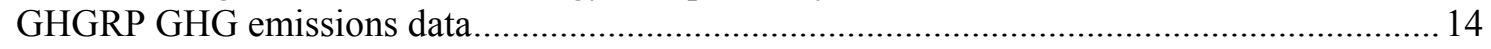

Figure 6. Absolute and relative number of GHGRP reported target industry facilities ........................... 15

Figure 7. Relative comparison of industrial-sector combustion energy use reported by EIA SEDS and calculated from GHGRP GHG emissions data for selected states... 
Figure 8. Cumulative distribution of calculated combustion energy use for iron and steel facilities in 2014 . 16

Figure 9. Calculated combustion energy use by fuel type in 2014 for target industries (PJ).................... 17

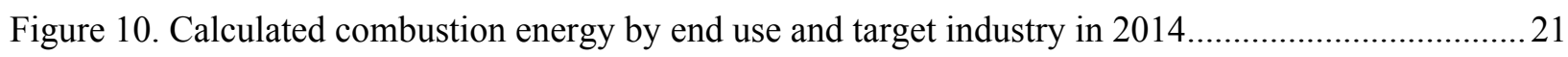

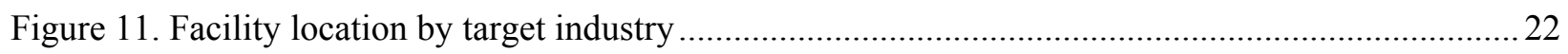

Figure 12. Distribution of target industry total thermal-energy use.....................................................22

Figure 13. Distribution of target industry thermal energy for cogeneration use.....................................22

Figure 14. Distribution of target industry thermal energy for conventional boiler use.............................23

Figure 15. Distribution of target industry thermal energy for direct process use ....................................23

Figure 16. U.S. refinery operating capacity in barrels per stream day, as of January 2016..................... 34

Figure 17. Energy use in synthetic gasoline production for use in methanol synthesis.............................38

Figure 18. Molecular diagram for ethylene and polyethylene polymer.................................................. 39

Figure 19. Integrated fluoride-salt cooled high temperature reactor (FHR) and steam-methane

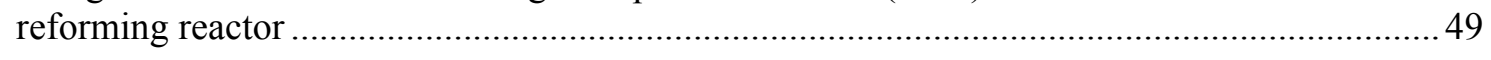

Figure 20. Planned capacity additions and nameplate capacity by state...............................................51

Figure 21. Geothermal resources of the United States (DOE 2016b) .................................................... 53

Figure 22. Operating conditions and performance of a 2-km helium circulation loop ..............................62 62

Figure 23. Operating conditions and performance of a 2-km molten-salt circulation loop ........................62

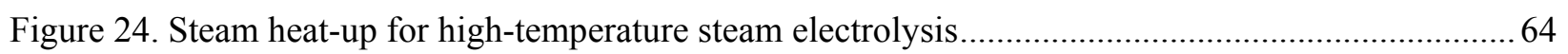

Figure C-1. Overall Material and Energy Flows for a Nominal Crude Oil Refinery ............................A-5

Figure D-1. Material and energy flows for a nominal iron and steel production plant..........................A-11

Figure D-2. Iron and steel production process flow diagram.........................................................A-13

Figure E-1. Material and energy flows for a nominal paper and paperboard plant. ............................A-16

Figure E-2. Paper and paperboard manufacturing process. ............................................................. A-18

Figure E-3. Energy use of U.S. paper manufacturing by end use energy type in 2002 (DOE-EIA

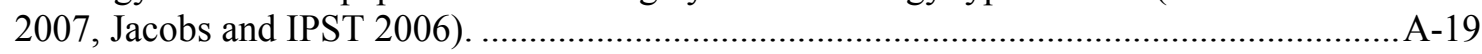

Figure E-4. Estimated energy-related GHG emissions of the U.S. paper industry in 2002 (DOE-

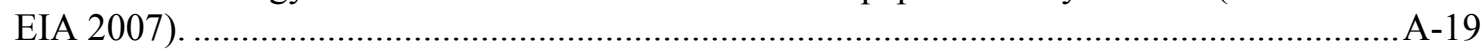

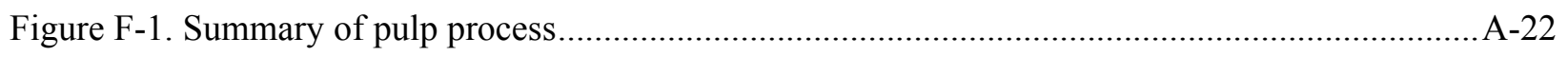

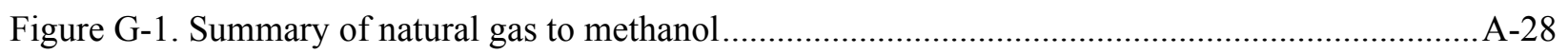

Figure G-2. Schematic of process for making methanol...............................................................

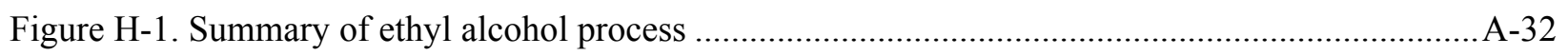

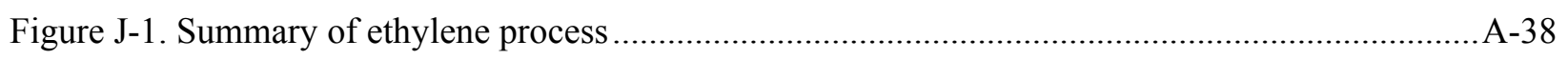

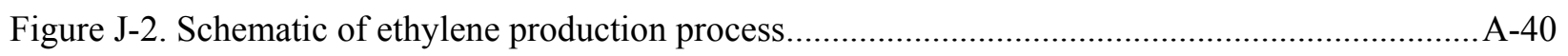

Figure K-1. Material and energy flows for a nominal chlorine-alkali plant ...................................... A-42 
Figure K-2. Sodium hydroxide and chlorine production process flow diagram using electrolysis (diaphragm cell).

Figure L-1. Summary of material and energy flows for a nominal ammonia plant producing urea and ammonium nitrate

Figure M-1. Material and energy flows for a nominal WCM plant.................................................

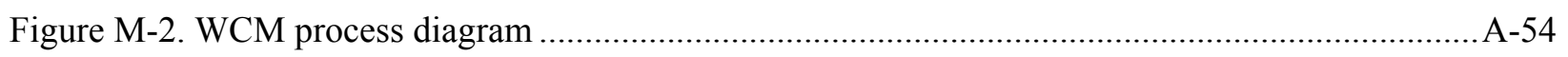

Figure M-3. WCM process steps along with energy usage ............................................................

Figure N-1. Material and energy flow summary for a nominal lime production plant ......................... A-57

Figure N-2. Lime production process flow diagram ....................................................................

Figure N-3. Typical Gas-Fired Portland cement kiln....................................................................

Figure N-4. Typical Portland cement clinker nodules .................................................................

Figure N-5. Material and energy flow summary for a nominal cement production plant .....................A-62

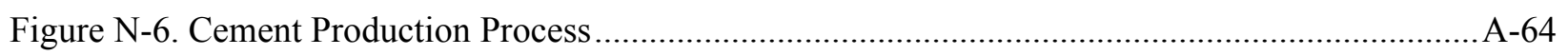

Figure O-1. Material and energy flows for a nominal Soda Ash (processing from Trona)

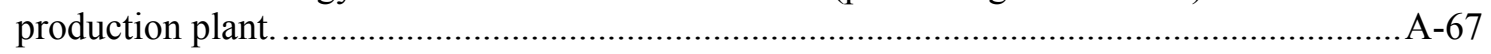

Figure O-2. Process flow for trona $\left(\mathrm{Na}_{2} \mathrm{CO}_{3} \cdot \mathrm{NaHCO}_{3} \cdot 2 \mathrm{H}_{2} \mathrm{O}\right)$ processing to produce soda ash

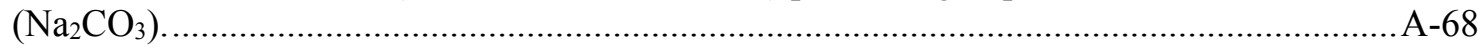

\section{TABLES}

Table ES-1. Summary of Potential Alternative Heat Supplies by Target Industry $(\mathrm{TJ}=$ terajoule $=$ $\left.10^{12} \mathrm{~J}\right)$

Table 1. EPA GHGRP Reported Emissions Data by U.S. Industry Subsector (Three-Digit NAICS

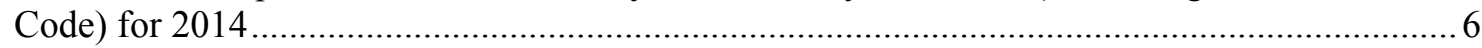

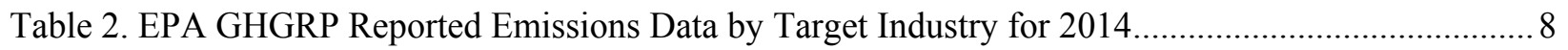

Table 3. Illustrative Facility Annual Energy Use Estimates Calculated from Annual GHGRP Data ........ 13

Table 4. Combustion-Unit Type Share of 2014 Calculated Combustion Energy Use by Target Industry

Table 5. Calculated Target Industry Energy by End Use in 2014 ........................................................ 20

Table 6. Estimated Fraction of Combustion Energy Used for CHP/Cogeneration.....................................24

Table 7. Production and Emissions of Selected Industries Based on Sum Total of Facilities

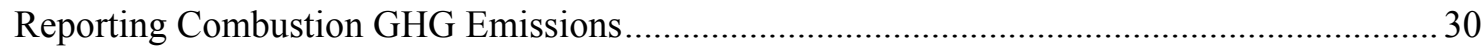

Table 8. Production and Emissions from Average Plant of Selected Industries ....................................... 31

Table 9. CSP Projects for Electricity Generation in the United States (NREL 2016a) ............................45

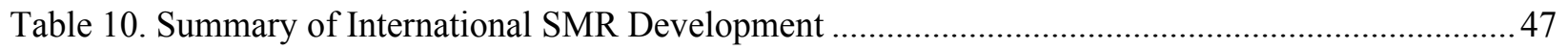

Table 13. Summary of Heat Generators and Potential Industrial Users .................................................55

Table 14. Number of SMR Units (150 MWt scale) required to meet Selected Industrial Needs ...............56

Table 15. Properties and Characteristics of Common Heat-Transfer Working Fluids .............................. 58 
Table C-1. Typical cut points for atmospheric and vacuum fractionators .............................................

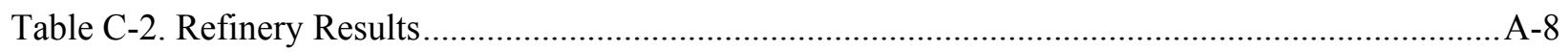

Table D-1. Net energy inputs and emissions for steel production ...................................................

Table E-1. Production comparison for paper and paperboard for 2002* and 2006 in the U.S..............A-20

Table E-2. Energy consumption of the U.S. paper industry (based on 2002 data, Kramer et al. 2009).

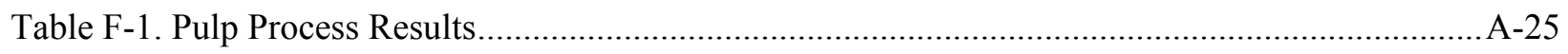

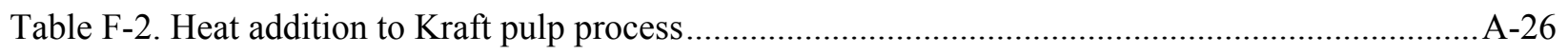

Table G-1. Inputs, products, utility, and emissions of natural gas to methanol process .........................

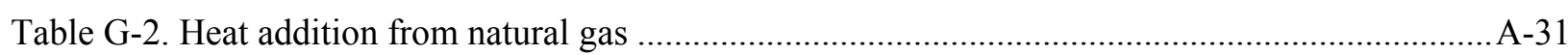

Table H-1. Inputs, Products, Utilities, and Emissions of Ethanol Biorefinery Process .........................A-34

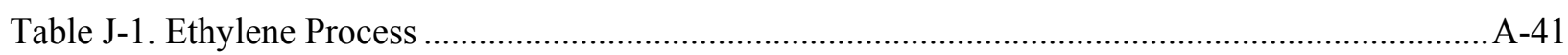

Table K-1. Chlorine and Alkali Process Summary for the United States.............................................45

Table L-1. Inputs, Products, Utility, and Emissions of Natural Gas to Ammonia Derivatives

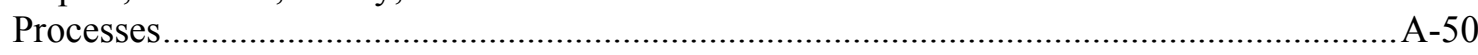

Table L-2. Heat Addition from Natural Gas ............................................................................

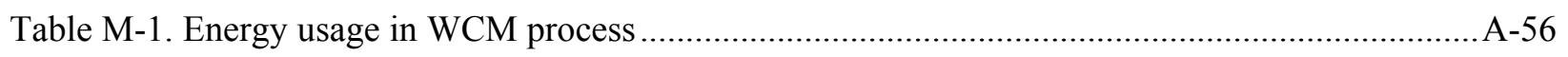

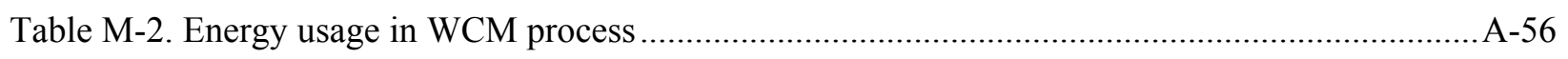

Table N-1. Energy usages of different types of lime kiln (Othmer 2016) ...........................................58

Table N-2. Average $\mathrm{CO}_{2}$ intensities for various lime products..........................................................5

Table N-3. Lime production energy usage* (Production and Facilities based on 2015) ........................ A-60

Table N-4. Cement production energy usage* (Production and Facilities based on 1999) ....................A-65

Table O-1. Energy consumption breakdown for soda ash production process from trona....................A-69 


\section{ACRONYMS AND ABBREVATIONS}

bpd

Btu

CBP

CEMI

$\mathrm{CH}_{4}$

$\mathrm{CHP}$

$\mathrm{CO}$

$\mathrm{CO}_{2}$

COP21

CSP

DOE

EERE

EGS

EIA

EJ

EP

EPA

EPRI

FCC

FDA

FHR

FIRES

FORGE

GHG

GHGRP

GJ

HES

HHV

HRSG

HTGR

HVAC

INL

$\mathrm{J}$

LINE

LWR

$\mathrm{ME}$

MECS

$\mathrm{MHz}$

MMBtu

$\mathrm{MMTCO}_{2} \mathrm{e}$

$\mathrm{MPa}$

$\mathrm{MTCO}_{2} \mathrm{e}$

MW

MWe

$\mathrm{MWh}$ barrels per day

British thermal unit

County Business Patterns

Clean Energy Manufacturing Initiative (Department of Energy)

methane

combined heat and power

carbon monoxide

carbon dioxide

Conference of the Parties

concentrating solar power

U.S. Department of Energy

Office of Energy Efficiency and Renewable Energy

Enhanced Geothermal Systems

U.S. Energy Information Administration

exajoules $\left(1 \mathrm{EJ}=10^{18} \mathrm{~J}\right)$

energy park

U.S. Environmental Protection Agency

Electric Power Research Institute

Federal Communications Commission

Food and Drug Administration

Fluoride-salt high temperature reactor

Firebrick Resistance-Heated Energy Storage

Frontier Observatory for Research in Geothermal Energy

greenhouse gas

EPA Greenhouse Gas Reporting Program

gigajoules $\left(1 \mathrm{GJ}=10^{9} \mathrm{~J}\right)$

hybrid energy system

higher heating value

heat recovery / steam generation

high-temperature gas reactor

heating, ventilating, and air conditioning

Idaho National Laboratory

joule

Leadership in Nuclear Energy

light-water reactor

multi-energy

Manufacturing Energy Consumption Survey

megahertz

million Btu $\left(1 \mathrm{MMBtu}=10^{6} \mathrm{Btu}\right)$

million metric tons carbon dioxide-equivalent

megapascal

metric tons carbon dioxide-equivalent

megawatt

megawatt-electric

megawatt-hour 
$\mathrm{MW}_{\mathrm{t}}$

NA

NAICS

NGNP

NNMI

$\mathrm{NO}_{\mathrm{x}}$

NRC

NREL

N-R HES

PEM

PJ

PRA

PV

PWR

Quads

RTO

SEDS

SEGS

SIPH

SMR

$\mathrm{T}-\mathrm{H}$

TJ

TBtu

USGS megawatt-thermal

not applicable

North American Industrial Classification System

Next-Generation Nuclear Plant [Program]

National Network for Manufacturing Innovation nitrogen oxides

U.S. Nuclear Regulatory Commission

National Renewable Energy Laboratory

nuclear-renewable hybrid energy system

proton-exchange membrane

petajoules $\left(1 \mathrm{PJ}=10^{15} \mathrm{~J}\right)$

probability risk assessment

photovoltaic

pressurized-water reactor

quadrillion Btu $\left(1\right.$ quad $\left.=10^{15} \mathrm{Btu}\right)$

regenerative thermal oxidizer

State Energy Data System

Solar Electric Generating Station

solar industrial process heat

small modular reactor

temperature-enthalpy

terajoules $\left(1 \mathrm{TJ}=10^{12} \mathrm{~J}\right)$

trillion Btu $\left(1 \mathrm{TBtu}=10^{12} \mathrm{Btu}\right)$

U.S. Geological Survey 


\section{Generation and Use of Thermal Energy in the U.S. Industrial Sector and Opportunities to Reduce its Carbon Emissions}

\section{INTRODUCTION}

On December 15, 2015, the United States joined more than 150 other countries at the $21^{\text {st }}$ session of the Conference of the Parties (COP21) in approving the Paris Agreement. The Agreement includes the aim to achieve rapid reductions in greenhouse gas (GHG) emissions that will result in net zero emissions in the second half of this century (UNFCCC 2015). The United States has pledged to reduce its emissions by $26 \%-28 \%$ below 2005 levels by 2025 (Department of State 2015). In 2014, the United States achieved net emissions 8.6\% below 2005 levels (EPA 2016a).

In 2014, the industrial sector was the third-largest source of direct ${ }^{3}$ U.S. GHG emissionsbehind electricity generation and transportation-accounting for roughly $20 \%$ of total emissions (EPA 2016a). About 58\% of U.S. industrial direct GHG emissions are the result of fuel combustion (EPA 2016). Use of combustible fuels is mostly driven by the demand for indirect heat in the form of steam from boilers and heat supplied directly to process reactors by in-situ combustion or process reactions. As a result, mitigating industrial direct GHG emissions necessarily involves changes to the ways that heat demands are met. This report provides an understanding of the opportunities for low-GHG-emitting thermal energy sources in the current industrial landscape.

Unlike emissions from all other economic sectors in the United States, industrial GHG emissions were below 1990 levels in 2014. Several factors have resulted in this emissions decline, including structural change of the economy, fuel switching, and energy efficiency. However, the sector's overall downward emissions trend has slowly reversed since the Great Recession (20072009) and emissions have nearly returned to pre-Recession levels.

As shown in Figure 1, industrial GHG emissions look much different through a global lens. The rapid rise in emissions that began in the early 2000s has continued into the current decade, largely unabated. Between 1990 and 2005, global direct emissions increased at an average annual rate of $0.7 \%$; from 2005 to 2010 , the average annual growth rate rose more than five-fold to $3.9 \%$ (Fischedick et al. 2014a).

\footnotetext{
${ }^{3}$ Direct emissions are the result of activities that occur on-site at a facility (U.S. EPA 2015).
} 


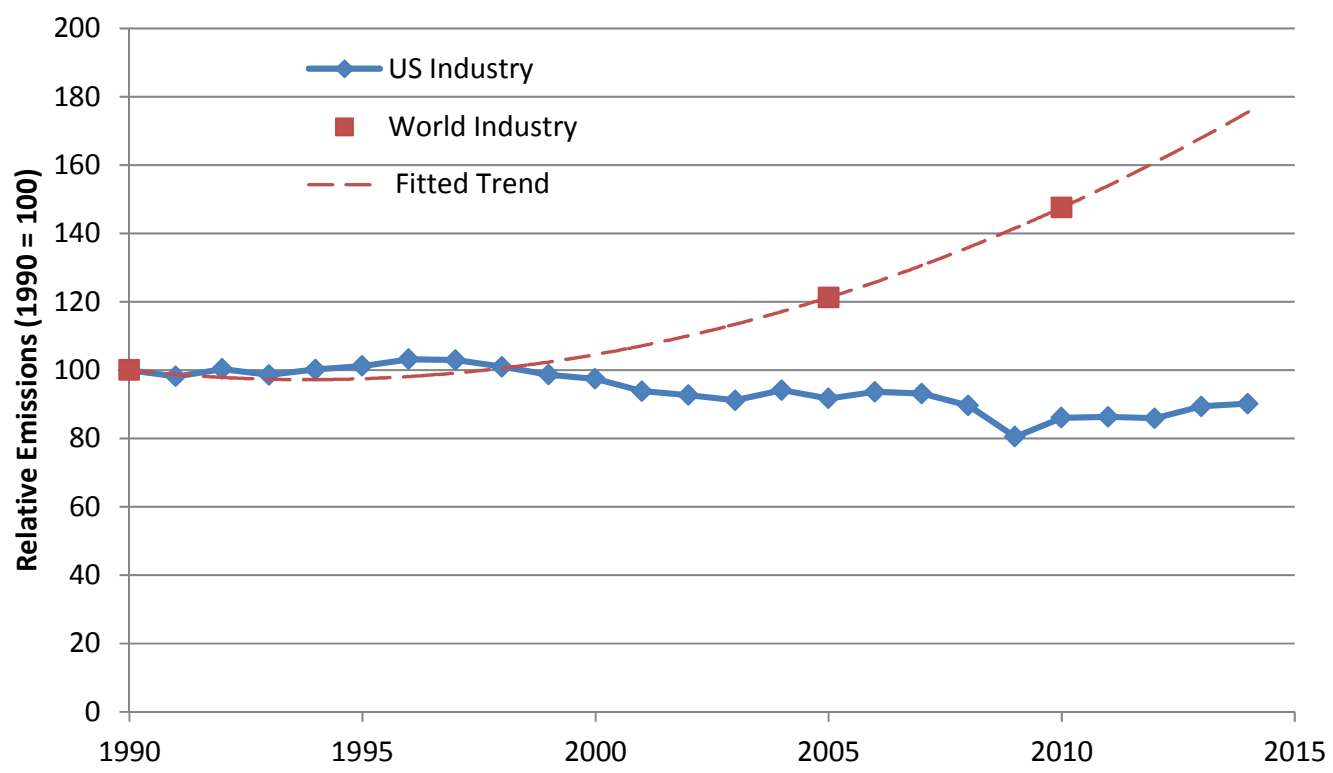

Figure 1. Trends in industrial GHG emissions for the United States and the world

Note: Data on direct, process, and low- $\mathrm{CO}_{2}$ emissions from EPA (2016a) and Fischedick et al. (2014a).

The heterogeneity of industrial processes and the complexity of modern industrial firms' global supply are among the sector's unique challenges to mitigating its GHG emissions. As a result of these challenges, achieving absolute reductions in industrial GHG emissions requires a varied combination of strategies, such as energy efficiency, material efficiency, and switching to lowcarbon fuels (Fischedick et al. 2014a). Recent analysis, however, questions whether current mitigation planning has paid sufficient attention to the sector. A 2015 review of 17 global decarbonization scenarios published from 2007 to 2012 found it "striking that relatively little planning has apparently occurred for the decarbonization of a sector responsible for one fifth of global emissions" (Loftus et al. 2015, 106). These concerns may be diminished by the more recent publication of individual industry decarbonization roadmaps for the European Union (e.g., Ecofys 2013; Wortler et al. 2016; CEMBUREAU 2013; UK Department of Energy \& Climate Change and UK Department for Business, Innovation \& Skills 2015). U.S. industry has not yet received such a detailed analytical treatment for decarbonization, either on a national level (Williams et al. 2015) or a state level (Wei et al. 2013; Yang et al. 2014; Wei et al. 2014; Greenblatt 2015).

The purpose of this report is to quantify the energy use and emissions for the most significant GHG-emitting U.S. industries based on targeted, process-level analysis of industrial heat requirements and to identify opportunities for those heat requirements to be replaced by lowGHG-emitting thermal energy sources. The target industries were chosen based on the magnitude of fuel-combustion GHG emissions. An analysis supporting this selection was conducted using national GHG inventory data and reported facility-level GHG emissions data from the U.S. Environmental Protection Agency (EPA). Our calculation of facility-level thermal energy demands from reported GHG emissions data by fuel type provides a level of detail that was not available from existing, publicly available industrial energy data sources such as the Energy Information Administration (EIA) Manufacturing Energy Consumption Survey (MECS) and State Energy Data System (SEDS). 
A detailed analysis was then performed for the target industries to identify relevant flows of energy, water, carbon dioxide $\left(\mathrm{CO}_{2}\right)$, and finished product for a typical facility. Identified characteristics of the industrial process and their heat requirements frame the discussion of relevant alternative heat supplies. Specifically, the scale and temperature of the required heat and heat-transport distance were considered as criteria for matching in-plant heat demands with external, alternative heat supplies. These alternatives included small module reactors (SMRs), solar industrial process heat (SIPH), and electrical heating.

Although a collection of technical, regulatory, and policy challenges exists, industry adoption of alternative heat supplies may offer the potential for additional benefits beyond reductions in GHG emissions and energy use. The alternative heat supplies identified in this report could serve as a foundation for clustering facilities in energy parks, which offers opportunities to effectively share energy and other resources, such as water. Additionally, alternative heat supplies that reduce operation costs or improve productivity could benefit the competitive edge of U.S. manufacturing.

Section 2 provides an overview of industrial GHG emissions, identifies the 14 most significant GHG-emitting industries, and describes the method used to estimate thermal energy demands by end use from reported GHG emissions data. Section 3 summarizes the results of process-level analysis of heat quantity and quality of the target industries. Section 4 discusses relevant alternative heat supplies and heat transfer considerations. Section 5 identifies analysis opportunities and Section 6 concludes the report. The report appendices provide additional background and technical detail of the process-level analysis summarized in Section 3. 


\section{INDUSTRIAL HEAT SURVEY}

The lack of publicly available energy data at the process and technology level is a challenge to mitigating industrial GHG emissions (Fischedick et al. 2014a). This section attempts to reduce the severity of this challenge by providing estimates of U.S. industrial thermal energy use at levels of detail not previously available to the public. Specifically, we calculated combustion energy use for detailed industries based on GHG emissions data reported on a facility level, identified the largest energy-using industries, and quantified combustion energy by end use. Section 2.1 describes the EPA Greenhouse Gas Reporting Program (GHGRP) and its data and identifies industries with the most significant GHG emissions from combustion. Section 2.2 describes the calculation of combustion energy use from GHG emissions data and compares the energy-use results with existing publicly available industrial energy data. Section 2.3 summarizes the conclusions of the analysis.

\subsection{Selecting Industries for Detailed Energy Analysis}

Fourteen industries were selected for assessing their emission characteristics based on analysis of national GHG inventory data and reported facility-level GHG emissions data obtained from the GHGRP. This selection then served as the starting point for detailed analysis that identified relevant flows of energy, water, $\mathrm{CO}_{2}$, and finished product for a typical facility in each target industry.

\subsubsection{EPA Greenhouse Gas Reporting Program}

National, state, and local-level GHG inventories identify the general sources of industrial-sector GHG emissions but do not provide industrial emissions by industry type, facility, or energy end use. Development of effective strategies for emissions reduction could benefit from a more detailed view of the types of industries and their end uses that primarily drive emissions and energy use. This has recently been made possible by the U.S. EPA's GHGRP, which began in 2010. Under the Mandatory Reporting of Greenhouse Gases Rule (Part 98), facilities with annual direct emissions greater than or equal to 25,000 metric tons $\mathrm{CO}_{2}$-equivalent $\left(\mathrm{MTCO}_{2} \mathrm{e}\right)$ are required to report to the EPA ("Mandatory Greenhouse Gas Reporting" 2009). Over 8,000 facilities representing nine industry sectors ${ }^{4}$ reported direct emissions of 3,200 million $\mathrm{MTCO}_{2} \mathrm{e}$ $\left(\mathrm{MMTCO}_{2} \mathrm{e}\right.$ ), or nearly half of U.S. total GHG emissions, for the 2014 reporting year (EPA 2016b). ${ }^{5}$ The majority of reported emissions come from power plants, which were responsible for $66 \%$ of total reported emissions $\left(2,100 \mathrm{MMTCO}_{2} \mathrm{e}\right)$ in 2014. Power plants include units that previously reported $\mathrm{CO}_{2}$ mass and heat input to the EPA year-round under 40 CFR part 75 (Continuous Emission Monitoring 1993). The remaining 34\% of reported emissions are mostly associated with industrial facilities.

GHGRP data are available from EPA's Envirofacts database and can be accessed based on Part 98 Subpart subject (U.S. EPA 2016d). Over 30 Subparts exist; these address emissions from fossil fuel combustion and industrial processes, as well as the production of fossil fuels, such as gasoline, that are combusted by other sectors. GHG emissions associated with industrial heat occur when fuels are combusted for direct use (e.g., process heating) or indirect use (e.g., in

\footnotetext{
${ }^{4}$ The EPA identifies these nine industry sectors as power plants, petroleum and natural gas systems, refineries, chemicals, waste, metals, minerals, pulp and paper, and "other" (U.S. EPA 2016b).

${ }^{5}$ The GHGRP covers $85-90 \%$ of total U.S. GHG emissions when supplier emissions are included (U.S. EPA 2016b).
} 
conventional boilers or for cogeneration). Data most relevant for analysis of industrial energy use are reported under Subpart C - General Stationary Fuel Combustion Sources and Subpart DElectricity Generation. Including only GHGRP reporters that identify as part of the industrial sector, ${ }^{6}$ emissions reported under Subpart C and Subpart D totaled $529 \mathrm{MMTCO}_{2} \mathrm{e}$ in 2014 . $^{7}$ Put into context of the U.S. GHG emissions inventory, the industrial facilities reporting under these Subparts account for $32 \%$ of all industrial-sector emissions and $7 \%$ of U.S. total emissions. ${ }^{8}$

\subsubsection{Identifying Industrial Energy Survey Target Industries}

We first aggregated GHGRP reporter data at the industry subsector level based on their threedigit North American Industrial Classification System (NAICS) ${ }^{9}$ code to determine which industries are the most significant direct GHG emitters. Emissions significance screening was performed in terms of largest absolute emissions $\left(>2.5 \mathrm{MMTCO}_{2} \mathrm{e}\right)$ and largest facility mean emissions $\left(>0.07 \mathrm{MMTCO}_{2} \mathrm{e}\right)$ by subsector. This initial screening identified eight subsectors as candidates for more detailed, process-level analysis based on subsector total emissions and facility mean emissions. The sum of reported emissions from these subsectors represents nearly $30 \%$ of the U.S. GHG inventory industrial sector total. Note again that the analysis includes only emissions reported under Subpart C - General Stationary Fuel Combustion Sources and Subpart D-Electricity Generation (excluding utility fossil fuel electric power generators).

\footnotetext{
${ }^{6}$ The industrial sector comprises agriculture (NAICS code 11), mining (NAICS code 21), construction (NAICS code 23), and manufacturing (NAICS codes $31-33$ ) establishments.

${ }^{7} \mathrm{GHG}$ emissions from biomass combustion are included in this total because the ultimate analysis goal is to characterize industrial heat demands, regardless of the energy carrier combusted. Disregarding reported $\mathrm{CO}_{2}$ emissions from biomass reduces industry emissions to about $486 \mathrm{MMTCO}_{2} \mathrm{e}$, equivalent to $33 \%$ of all industrialsector emissions and 7\% of U.S. total emissions.

${ }^{8}$ Although the EPA national inventory does not include $\mathrm{CO}_{2}$ emissions from biomass in reported sums, these emissions have been added to industry $\left(124.4 \mathrm{MMTCO}_{2} \mathrm{e}\right)$ and national $\left(217.7 \mathrm{MMTCO}_{2} \mathrm{e}\right)$ totals as a more appropriate comparison with GHGRP-reported emissions.

${ }^{9}$ NAICS is a system of six-digit hierarchical codes used to categorize economic activity. The first two digits indicate the sector, the third digit the subsector, the fourth digit the industry group, the fifth digit the industry, and the sixth digit the U.S.-specific industry.
} 
Table 1. EPA GHGRP Reported Emissions Data by U.S. Industry Subsector (Three-Digit NAICS Code) for 2014

\begin{tabular}{|c|c|c|c|c|c|}
\hline Industry Subsector & $\begin{array}{l}\text { NAICS } \\
\text { Code }\end{array}$ & $\begin{array}{l}\text { Number of } \\
\text { Reporting } \\
\text { Facilities }\end{array}$ & $\begin{array}{l}\text { Facility } \\
\text { Mean } \\
\text { Emissions* } \\
\left(\mathrm{MMTCO}_{2} \mathrm{e}\right)\end{array}$ & $\begin{array}{l}\text { Total } \\
\text { Emissions* } \\
\left(\mathrm{MMTCO}_{2} \mathrm{e}\right)\end{array}$ & $\begin{array}{l}\text { Fraction of } \\
\text { Industry Sector } \\
\text { Emissions* } \\
\text { (\%) }\end{array}$ \\
\hline $\begin{array}{l}\text { Petroleum and Coal } \\
\text { Products }\end{array}$ & 324 & 176 & 0.731 & 129 & 8 \\
\hline $\begin{array}{l}\text { Chemical } \\
\text { Manufacturing }\end{array}$ & 325 & 616 & 0.180 & 111 & 7 \\
\hline Primary Metals & 331 & 272 & 0.244 & 66 & 4 \\
\hline $\begin{array}{l}\text { Paper } \\
\text { Manufacturing }\end{array}$ & 322 & 230 & 0.302 & 70 & 4 \\
\hline Food Manufacturing & 311 & 322 & 0.112 & 36 & 2 \\
\hline $\begin{array}{l}\text { Nonmetallic Mineral } \\
\text { Products }\end{array}$ & 327 & 326 & 0.070 & 23 & 1 \\
\hline $\begin{array}{l}\text { Wood Product } \\
\text { Manufacturing }\end{array}$ & 321 & 22 & 0.123 & 2.7 & 0.2 \\
\hline Agriculture & 111,115 & 5 & 0.139 & 0.694 & 0.04 \\
\hline \multicolumn{2}{|l|}{ Total } & 1,969 & 0.223 & 438 & 27 \\
\hline
\end{tabular}

* Includes $\mathrm{CO}_{2}$ from biomass combustion

To more specifically target the most significant GHG emitters, we separated industry subsectors by U.S.-specific industry based on six-digit NAICS code and selected industries with the highest total and facility mean emissions. This revealed 14 industries that were selected for process-level analysis. ${ }^{10}$ As shown in Figure 2, the direct-combustion emissions of the 960 facilities in these industries collectively constitute nearly one-quarter of U.S. GHG inventory industrial-sector emissions, equivalent to 5\% of U.S. total emissions in 2014. Table 2 summarizes reported emissions by target industry. Appendix A summarizes general descriptions of the activities of each target industry. Later in the report, we provide further discussion on production process, energy intensity of the process (energy consumption per unit of manufactured product), along with power requirement and net emissions for the target industries.

\footnotetext{
${ }^{10}$ The selection threshold was industry total emissions above $10 \mathrm{MMTCO}_{2} \mathrm{e}$, but this was amended to include lime manufacturing, nitrogenous fertilizer manufacturing, and potash, soda, and borate mining based on their facility mean emissions $\left(>0.2 \mathrm{MMTCO}_{2} \mathrm{e}\right)$. Industries that were excluded from selection include primary aluminum production, industrial gas manufacturing, cement manufacturing, glass container manufacturing, and iron foundries. In sum, 2,351 facilities representing 193 specific industries and $160 \mathrm{MMTCO}_{2} \mathrm{e}$ emissions were excluded from the analysis.
} 


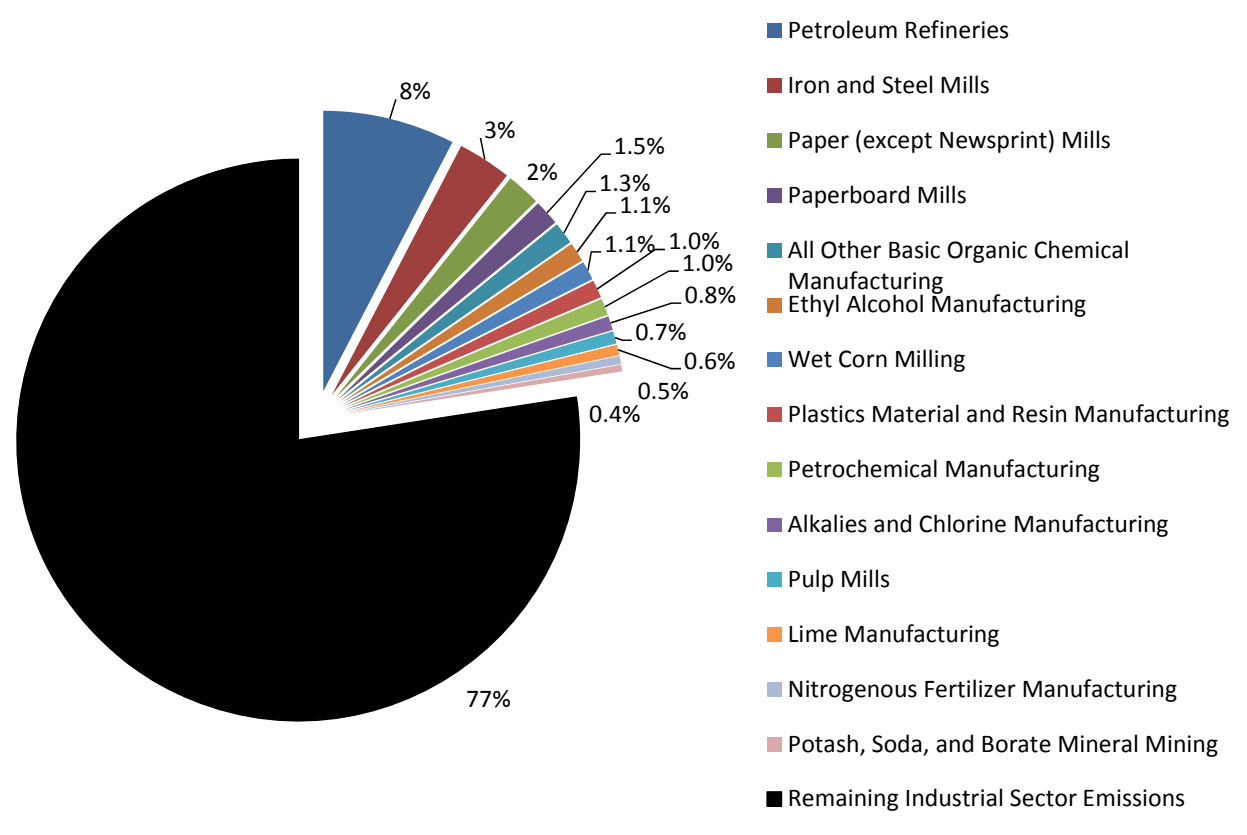

Figure 2. Target industry fraction of industrial sector total GHG emissions for 2014 
Table 2. EPA GHGRP Reported Emissions Data by Target Industry for 2014

\begin{tabular}{|c|c|c|c|c|c|c|}
\hline $\begin{array}{l}\text { Industry } \\
\text { Subsector }\end{array}$ & Target Industry & $\begin{array}{l}\text { NAICS } \\
\text { Code }\end{array}$ & $\begin{array}{l}\text { Number of } \\
\text { Reporting } \\
\text { Facilities }\end{array}$ & $\begin{array}{l}\text { Facility Mean } \\
\text { Emissions } \\
\left(\mathrm{MMTCO}_{2} \mathrm{e}\right)^{*}\end{array}$ & $\begin{array}{l}\text { Total Emissions } \\
\left(\mathrm{MMTCO}_{2} \mathrm{e}\right)^{*}\end{array}$ & $\begin{array}{l}\text { Fraction of } \\
\text { Industrial } \\
\text { Sector } \\
\text { Emissions } \\
(\%)^{*}\end{array}$ \\
\hline $\begin{array}{l}\text { Petroleum } \\
\text { and Coal } \\
\text { Products } \\
\text { Manufacturing }\end{array}$ & Petroleum Refineries & 324110 & 141 & 0.882 & 124 & 8 \\
\hline $\begin{array}{l}\text { Primary Metal } \\
\text { Manufacturing }\end{array}$ & Iron and Steel Mills & 331111 & 115 & 0.440 & 51 & 3 \\
\hline & $\begin{array}{l}\text { Paper (except } \\
\text { Newsprint) Mills }\end{array}$ & 322121 & 116 & 0.275 & 32 & 2 \\
\hline Manufacturing & Paperboard Mills & 322130 & 73 & 0.327 & 24 & 1.5 \\
\hline & Pulp Mills & 322110 & 30 & 0.395 & 12 & 0.7 \\
\hline & $\begin{array}{l}\text { All Other Basic } \\
\text { Organic Chemical } \\
\text { Manufacturing }\end{array}$ & 325199 & 85 & 0.245 & 21 & 1.3 \\
\hline & $\begin{array}{l}\text { Ethyl Alcohol } \\
\text { Manufacturing }\end{array}$ & 325193 & 168 & 0.109 & 18 & 1.1 \\
\hline Chemical & $\begin{array}{l}\text { Plastics Material and } \\
\text { Resin Manufacturing }\end{array}$ & 325211 & 72 & 0.235 & 17 & 1.0 \\
\hline & $\begin{array}{l}\text { Petrochemical } \\
\text { Manufacturing }\end{array}$ & 325110 & 35 & 0.450 & 16 & 1.0 \\
\hline & $\begin{array}{l}\text { Alkalies and Chlorine } \\
\text { Manufacturing }\end{array}$ & 325181 & 11 & 1.223 & 13 & 0.8 \\
\hline & $\begin{array}{l}\text { Nitrogenous Fertilizer } \\
\text { Manufacturing }\end{array}$ & 325311 & 30 & 0.252 & 8 & 0.5 \\
\hline $\begin{array}{l}\text { Food } \\
\text { Manufacturing }\end{array}$ & Wet Corn Milling & 311221 & 24 & 0.744 & 18 & 1.1 \\
\hline $\begin{array}{l}\text { Nonmetallic } \\
\text { Mineral } \\
\text { Product } \\
\text { Manufacturing }\end{array}$ & Lime Manufacturing & 327410 & 49 & 0.201 & 10 & 0.6 \\
\hline $\begin{array}{l}\text { Mining } \\
\text { (Except Oil } \\
\text { and Gas) }\end{array}$ & $\begin{array}{l}\text { Potash, Soda, and } \\
\text { Borate Mineral Mining }\end{array}$ & 212391 & 11 & 0.568 & 6 & 0.4 \\
\hline \multicolumn{3}{|c|}{ Total } & 960 & 0.385 & 369 & 23 \\
\hline
\end{tabular}

${ }^{*}$ Includes $\mathrm{CO}_{2}$ from biomass combustion 
Figure 3 summarizes the 2014 GHG emissions of the 14 target industries in relation to GHGRPreported emissions for all industries and industrial sector emissions. Industrial sector emissions have been identified as stationary combustion, industrial processes ${ }^{11}$, and non-energy use and fossil fuel systems (i.e., coal mining, natural gas systems, and petroleum systems). The figure shows that industrial facilities subject to the GHGRP reported emissions of $529 \mathrm{MMTCO}_{2} \mathrm{e}$ from fuel combustion, which is the equivalent of $56 \%$ of U.S. GHG inventory industry stationary combustion emissions. The target industries represent nearly $40 \%$ of U.S. GHG inventory industry stationary combustion emissions.

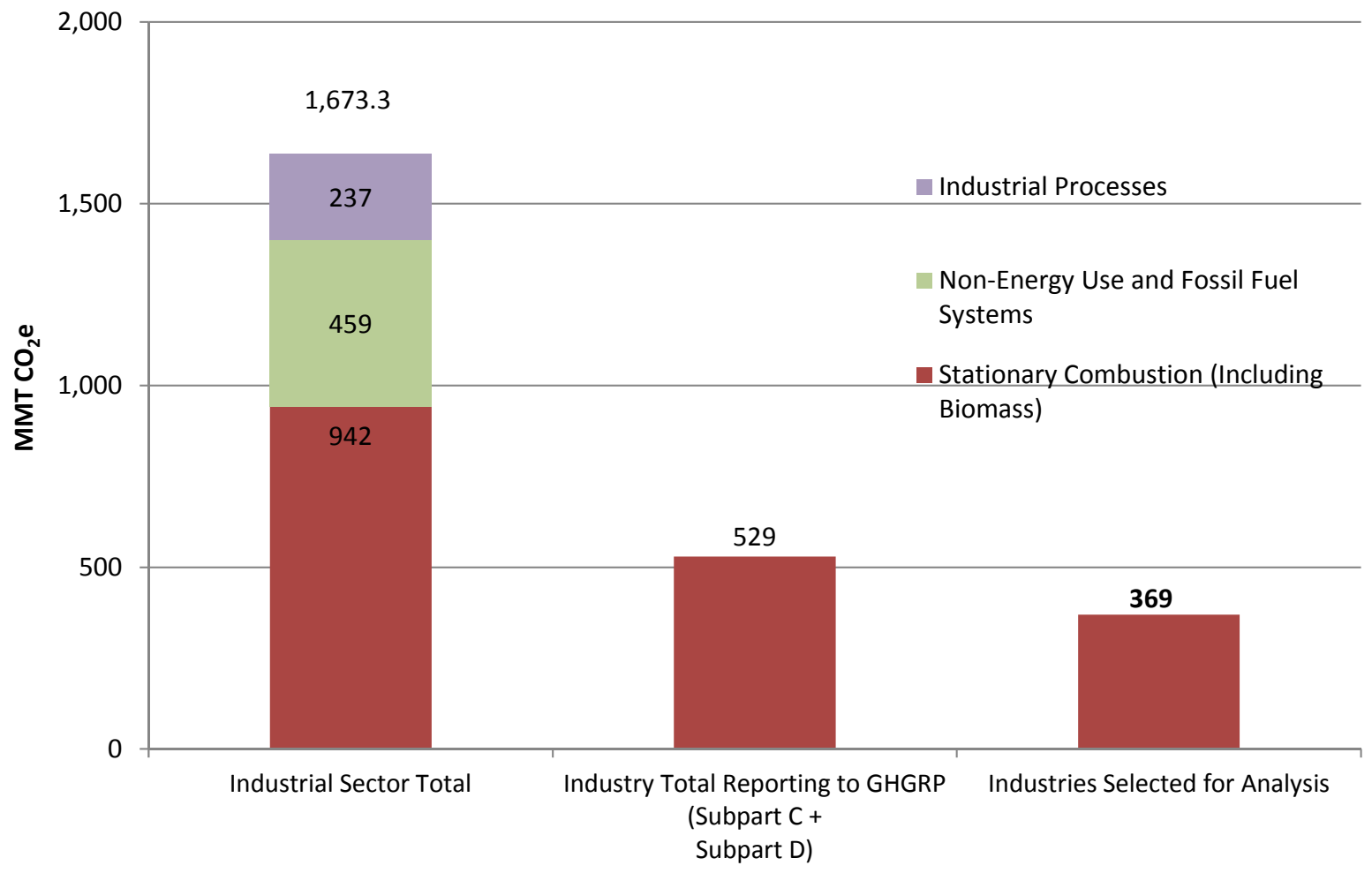

Figure 3. U.S. industrial greenhouse gas emissions in 2014 Source: Data from EPA (2016a); EPA (2016b)

\subsection{Combustion Energy Use Analysis of Target Industries}

We used GHGRP-reported data and GHG emissions factors to calculate facility combustion energy use for the 14 target industries. This section details the three calculation approaches that we applied to GHGRP data and provides a summary and analysis of calculation results.

\footnotetext{
${ }^{11}$ Industrial process GHG emissions occur as the result of industrial activities, but not as the direct result of fossil fuel combustion. For example, the reduction of iron ore to iron and the calcination of limestone to quicklime are industrial activities whose reactions evolve $\mathrm{CO}_{2}$. Industrial process emissions were not considered for this analysis because they are not the direct result of fossil fuel combustion and therefore are not impacted by the use of low-carbon alternative heat supplies.
} 


\subsubsection{Calculating Thermal Energy Use from EPA Greenhouse Gas Reporting Program Data}

We calculated facility thermal energy use for the target industries based on GHG emissions data reported under Subpart C - General Stationary Fuel Combustion Sources and energy data reported under Subpart D-Electricity Generation (excluding utility fossil fuel electric power generators). Facilities reporting GHG emissions under Subpart C use one of four calculation methodologies or "tiers." These tiers provide reporters with varying levels of specificity for the type and quantity of fuel combusted and are described as follows (EPA 2016c):

- Tier 1 emissions are calculated using default EPA emission factors (kilograms $\mathrm{CO}_{2}$ per million British thermal units [MMBtu]) and company fuel-purchase records.

- Tier 2 emissions are calculated with default and fuel-specific data such as emission factors, measured high heating values, and company fuel-purchase records.

- Tier 3 emissions are calculated with fuel-specific data on carbon contents, higher heating values, and measured fuel quantities.

- Tier 4 emissions are measured via gas concentration and gas flow rate obtained from continuous emission monitoring equipment.

- In addition to these four tiers, facilities with combustion units that are subject to the continuous emissions monitoring requirements of 40 CFR Part 75 can calculate GHG emissions using heat-input and fuel-use data already collected for Part 75.

We used the fuel types and emissions reported under Subpart C, as well as heat-input values reported under Part 75 for Subpart D, to estimate facility annual combustion energy demand in one of three approaches. ${ }^{12}$ Approach 1 and Approach 2 are based on reported emissions and EPA default emission factors by fuel type. Approach 3 is based on reported heat input by fuel type.

Strictly speaking, these estimates serve as proxies for total thermal energy demand because they capture only the heat content of fuels combusted for a given facility and do not include the purchases of steam and electricity that may also be used to meet heat demands. Emissions from the generation of purchased steam are captured by reporters identifying as NAICS 221330 Steam and Air Conditioning Supply. Emissions in 2014 from these facilities totaled 8.1 MMTCO2e. Alternative heat supplies that substitute for purchased steam generated from fossil fuel combustion may also be a source of GHG mitigation.

We used Approach 1 to calculate energy use from facilities reporting Tier 1, Tier 2, or Tier 3 $\mathrm{CO}_{2}$ emissions. The energy use by fuel type was calculated by dividing the reported mass of $\mathrm{CO}_{2}$ by the default $\mathrm{CO}_{2}$ emission factor provided by the EPA (EPA 2015). ${ }^{13}$ We matched reported fuel types that were not included in the EPA-provided emissions factors to their closest default fuel type.

\footnotetext{
12 Relevant GHGRP data are obtained from the C_FUEL_LEVEL_INFORMATION and D_FUEL_LEVEL_INFORMATION tables using the EPA Envirofacts Data Service Application Programming Interface (U.S. EPA 2016e).

${ }^{13}$ Emission factors are based on the higher heating value (HHV) of combustion fuels.
} 
Approach 1 calculates facility energy use (in GJ, gigajoules, $10^{9} \mathrm{~J}$ ) associated with combustion fuel type $t, E t$, as

$$
E_{t}=G H G_{\mathrm{CO} 2, t} \div E F_{\mathrm{CO} 2, t} \times 1.055 \mathrm{GJ} / \mathrm{MMBtu},
$$

where $\mathrm{GHG}_{\mathrm{CO}_{2}, t}$ and $E F_{\mathrm{CO}_{2}, t}$ are the reported emissions and $\mathrm{EPA}$ default emission factors of $\mathrm{CO}_{2}$.

We used Approach 2 to calculate energy use for facilities reporting emissions with the Tier 4 methodology. $\mathrm{CO}_{2}$ emissions reported using Tier 4 are not included in the same dataset as Tier 1 to Tier 3 emissions, so instead, Approach 2 calculated energy use by fuel type based on reported methane $\left(\mathrm{CH}_{4}\right)$ emissions and the default methane emissions factors. We matched reported fuel types that were not included in the EPA-provided emissions factors to their closest default fuel type.

Approach 2 calculates facility energy use as

$$
E_{t}=G H G_{\mathrm{CH} 4, t} \div E F_{\mathrm{CH} 4, t} \times 1.055 \mathrm{GJ} / \text { MMBtu},
$$

where $G H G_{\mathrm{CH}_{4}, t}$ and $E F_{\mathrm{CH}_{4}, t}$ are the reported emissions and $\mathrm{EPA}$ default emission factors $\mathrm{CH}_{4}$ for fuel type $t$, respectively.

Energy use was calculated in Approach 3 based directly on heat-input and fuel-use data reported to the GHGRP database for facilities that are required to report under Part 75. Note that a given facility may report emissions using multiple tiers, in addition to emissions calculated from Part 75 data.

Approach 3 calculates facility energy use as

$$
E_{t}=H_{t} \times 1.055 \mathrm{GJ} / \mathrm{MMBtu},
$$

where $H_{t}$ is the heat input in MMBtu reported under Part 75.

Figure 4 summarizes how the three approaches are applied to GHGRP-reported facility emissions and heat input by fuel type.

Four illustrative examples of the three energy-calculation approaches are provided in Table 3. Energy use for facilities A and $\mathrm{B}$ was calculated using reported $\mathrm{CO}_{2}$ emissions and the associated EPA default emission factor (Approach 1). We performed an additional calculation for facility B using $\mathrm{CH}_{4}$ emissions and $\mathrm{CH}_{4}$ emission factor (Approach 2) because emissions from bituminous coal combustion were reported using the Tier 4 methodology. Reported emissions are not used to estimate energy use for facility $\mathrm{C}$ because the facility directly reports heat-input data for distillate fuel (Approach 3). 


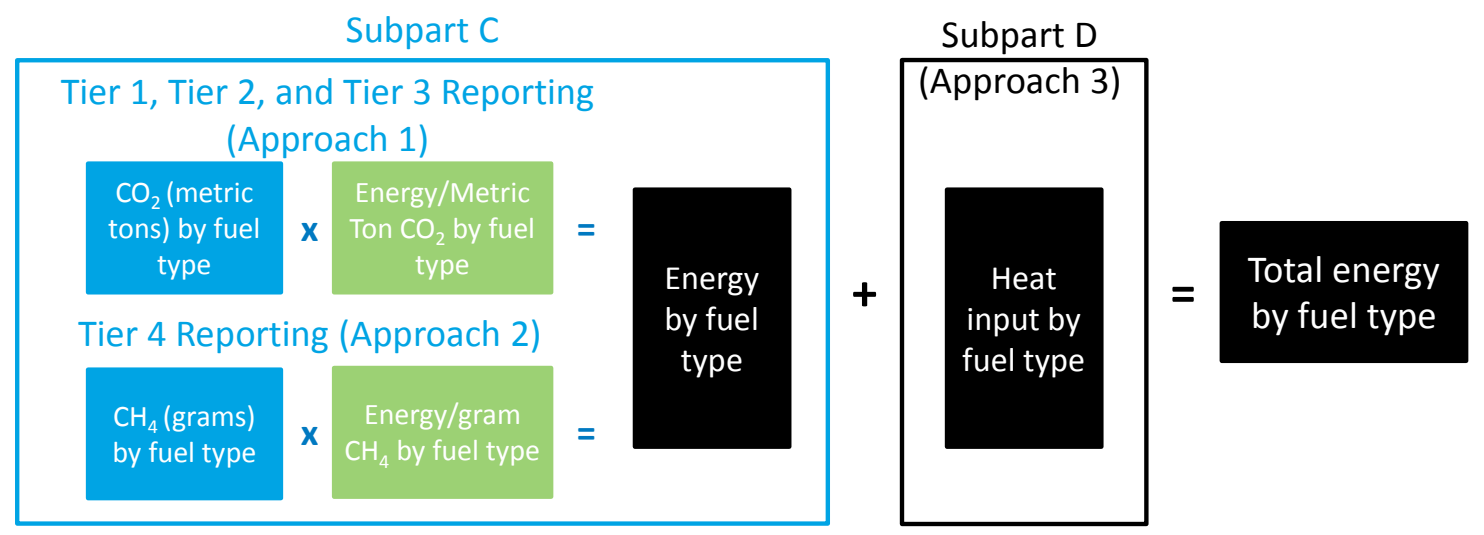

Figure 4. Generalized calculation of facility combustion energy use from GHGRP-reported emissions and heat input 
Table 3. Illustrative Facility Annual Energy Use Estimates Calculated from Annual GHGRP Data

\begin{tabular}{|c|c|c|c|c|c|c|c|c|}
\hline Facility & $\begin{array}{l}\text { Reported } \\
\text { Fuel Type }\end{array}$ & $\begin{array}{l}\text { Reported } \\
\text { Subpart C } \\
\text { Methodology }\end{array}$ & $\begin{array}{l}\text { Reported } \\
\mathrm{CO}_{2} \\
\text { Emissions } \\
\text { (metric tons } \\
\mathrm{CO}_{2} \text { ) }\end{array}$ & $\begin{array}{l}\text { Tier } 4 \text { Reported } \\
\mathrm{CH}_{4} \text { Combustion } \\
\text { Emissions } \\
\text { (metric tons } \mathrm{CH}_{4} \text { ) }\end{array}$ & $\begin{array}{l}\text { EPA Default } \\
\text { Emission Factor }\end{array}$ & $\begin{array}{l}\text { Part } 75 \\
\text { Annual } \\
\text { Heat Input } \\
\text { (MMBtu) }\end{array}$ & $\begin{array}{l}\text { Estimated } \\
\text { Energy } \\
\text { Use in TJ } \\
\text { (TBtu) }\end{array}$ & $\begin{array}{l}\text { Estimation } \\
\text { Approach }\end{array}$ \\
\hline A & $\begin{array}{l}\text { Natural Gas } \\
\text { (Weighted } \\
\text { U.S. Average) }\end{array}$ & Tier 1 & 30,000 & NA & $\begin{array}{l}53.06 \mathrm{~kg} \\
\mathrm{CO}_{2} / \mathrm{MMBtu}\end{array}$ & NA & $\begin{array}{l}598 \\
(0.567)\end{array}$ & Approach 1 \\
\hline B & Propane & Tier 2 & 5,000 & NA & $\begin{array}{l}61.46 \mathrm{~kg} \\
\mathrm{CO}_{2} / \mathrm{MMBtu}\end{array}$ & NA & $\begin{array}{l}86 \\
(0.082)\end{array}$ & Approach 1 \\
\hline B & $\begin{array}{l}\text { Bituminous } \\
\text { Coal }\end{array}$ & Tier 4 & NA & 75 & $11 \mathrm{~g} \mathrm{CH}_{4} / \mathrm{MMBtu}$ & NA & $\begin{array}{l}7,193 \\
(6.818)\end{array}$ & Approach 2 \\
\hline C & $\begin{array}{l}\text { Distillate Fuel } \\
\text { Oil No. } 2\end{array}$ & NA & NA & NA & NA & 12,000 & $\begin{array}{l}14 \\
(0.013)\end{array}$ & Approach 3 \\
\hline
\end{tabular}

$\mathrm{NA}=$ not applicable 


\subsubsection{Summary of Calculated Industrial Energy ${ }^{14}$}

The GHGRP applies only to large emitters and the increase in detail comes at the cost of overall coverage of the industrial sector. However, we note that these large emitters (and, by proxy, large fuel and energy users) are more relevant than smaller emitters (i.e., small energy users) for nuclear-generated thermal energy.

The tradeoff between detail and industry coverage is demonstrated by comparing our calculated energy data with existing, published estimates of manufacturing and state-level industrial energy use available from EIA. The latest EIA MECS represents 170,166 facilities and provides data at the six-digit NAICS code level for 47 manufacturing industries (EIA 2015). Conversely, GHGRP data in 2014 represent 2,253 facilities and 182 manufacturing industries at the six-digit NAICS code level. The 2010 MECS indicates that manufacturing industries used 12,440 PJ (11.79 quads) of fuels for combustion. In 2010, manufacturing industries reporting to the GHGRP, comprising just over $1 \%$ of the MECS sample size, are estimated to have reported the equivalent of 6,477 PJ (6.139 quads) of fuel combustion - the equivalent of 52\% of the MECS fuel-combustion energy. Figure 5 makes additional comparisons between manufacturing fuel combustion as reported by the 2010 MECS and as estimated from GHGRP data for 2010 through 2014.

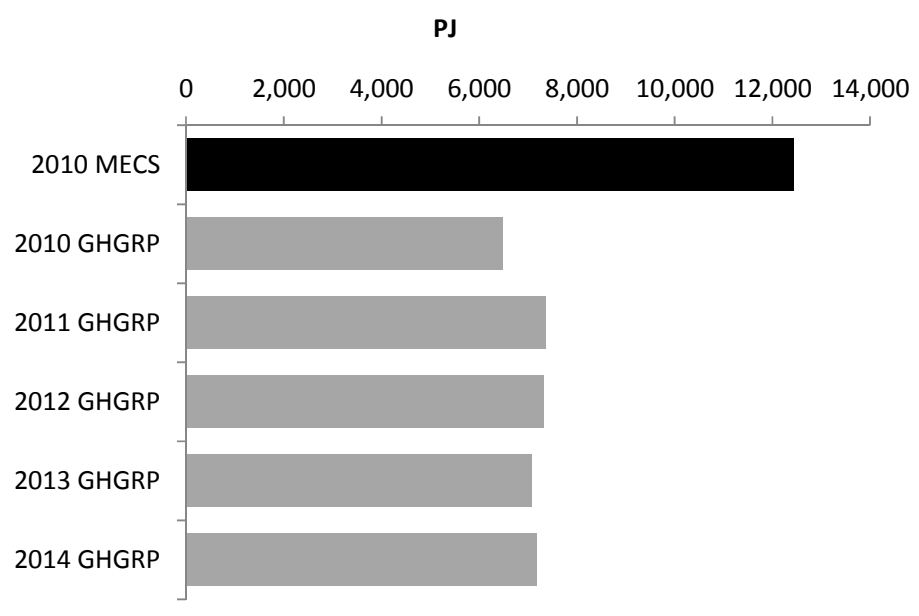

Figure 5. Manufacturing fuel-combustion energy as reported by EIA MECS and calculated from GHGRP GHG emissions data

Figure 6 depicts the number of GHGRP reporting facilities in absolute terms and relative to facility counts from the 2010 MECS (EIA 2015) as well as the 2014 County Business Patterns (CBP) (U.S. Census Bureau 2016). As shown in Figure 6, the GHGRP represents a higher proportion of emissions-intensive industries than total manufacturing industries. GHGRP coverage is highest for Petroleum Refineries (324110), Ethyl Alcohol Manufacturing (325193), Petrochemical Manufacturing (325110), and Pulp Mills (322110). For these industries, the GHGRP represents between $61 \%$ and $91 \%$ of the CBP or MECS facility counts. The GHGRP captures the fewest Plastics Material and Resin Manufacturing and Other Basic Organic

\footnotetext{
${ }^{14}$ Calculated facility-level energy data are available from the NREL Data Catalog (NREL 2016)
} 
Chemical Manufacturing facilities. Note that the total number of target industry facilities (960) represents $0.3 \%$ of $2014 \mathrm{CBP}$ facilities and $0.6 \%$ of MECS facilities.

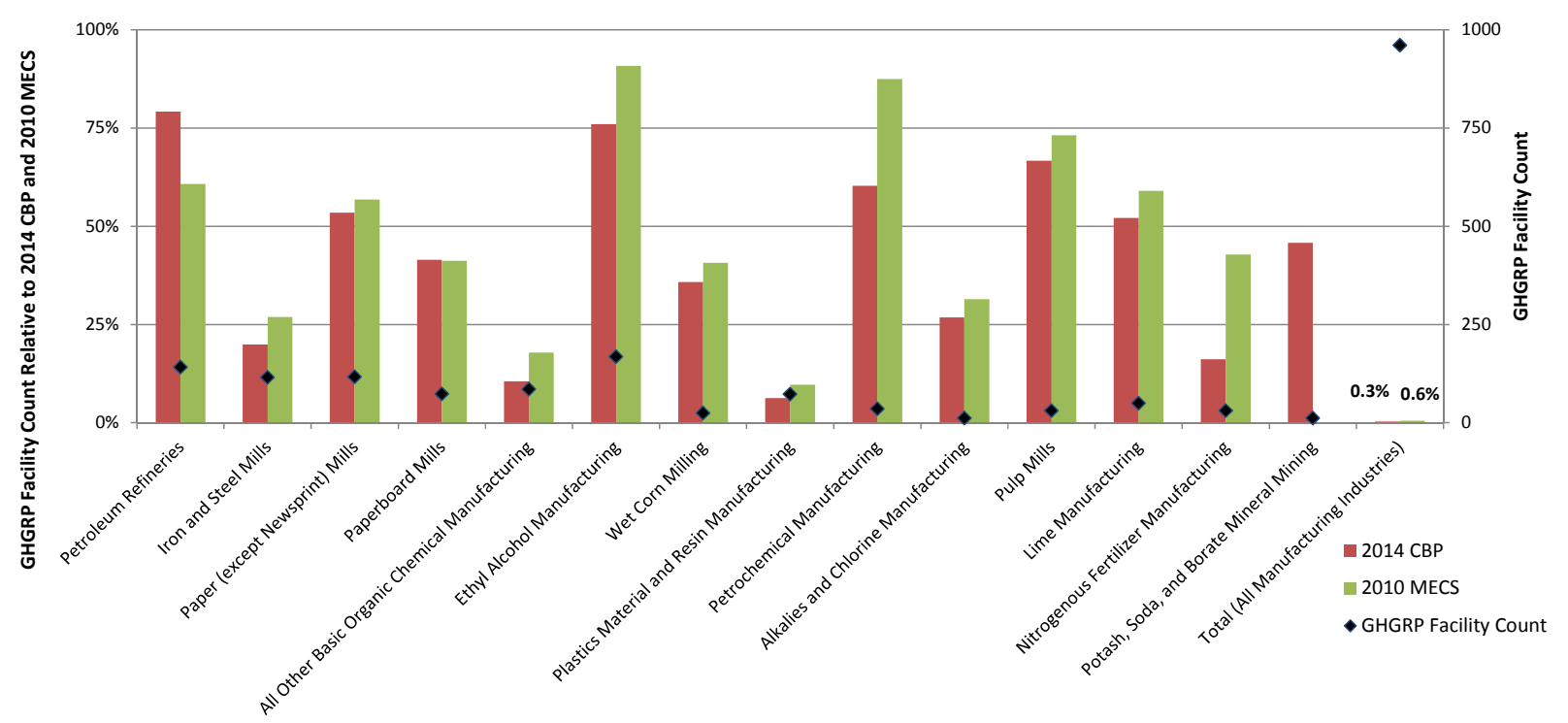

Figure 6. Absolute and relative number of GHGRP reported target industry facilities ${ }^{15}$

State-level comparisons can be made between our calculated industrial-sector energy use and the EIA's SEDS. Figure 7 compares industrial-sector combustion energy (total industrial energy excluding electricity losses less electricity consumption) data with energy use calculated from GHGRP emissions and fuel-type data and aggregated by state. GHGRP estimates are shown normalized to SEDS data for a given state, with a value of 100 indicating that the values from both sources are equal. For instance, the value shown for Maine in 2013 is 72, which indicates that the industrial combustion energy use estimated from GHGRP emissions data is $72 \%$ of the energy use reported by SEDS. Figure 7 summarizes these relative values for the ten states for which industrial energy use is most-closely and least-closely matched between available SEDS data and estimates from GHGRP data for 2013.

\footnotetext{
${ }^{15}$ The 2012 NAICS revision aggregated Alkalies and Chlorine Manufacturing (325181) with Other Basic Inorganic Chemical Manufacturing (325180). The number of GHGRP reporting facilities classified as 325181 are shown relative to the number of facilities that appear in the 2011 CBP, the final CBP to separately identify this U.S. specific industry.
} 


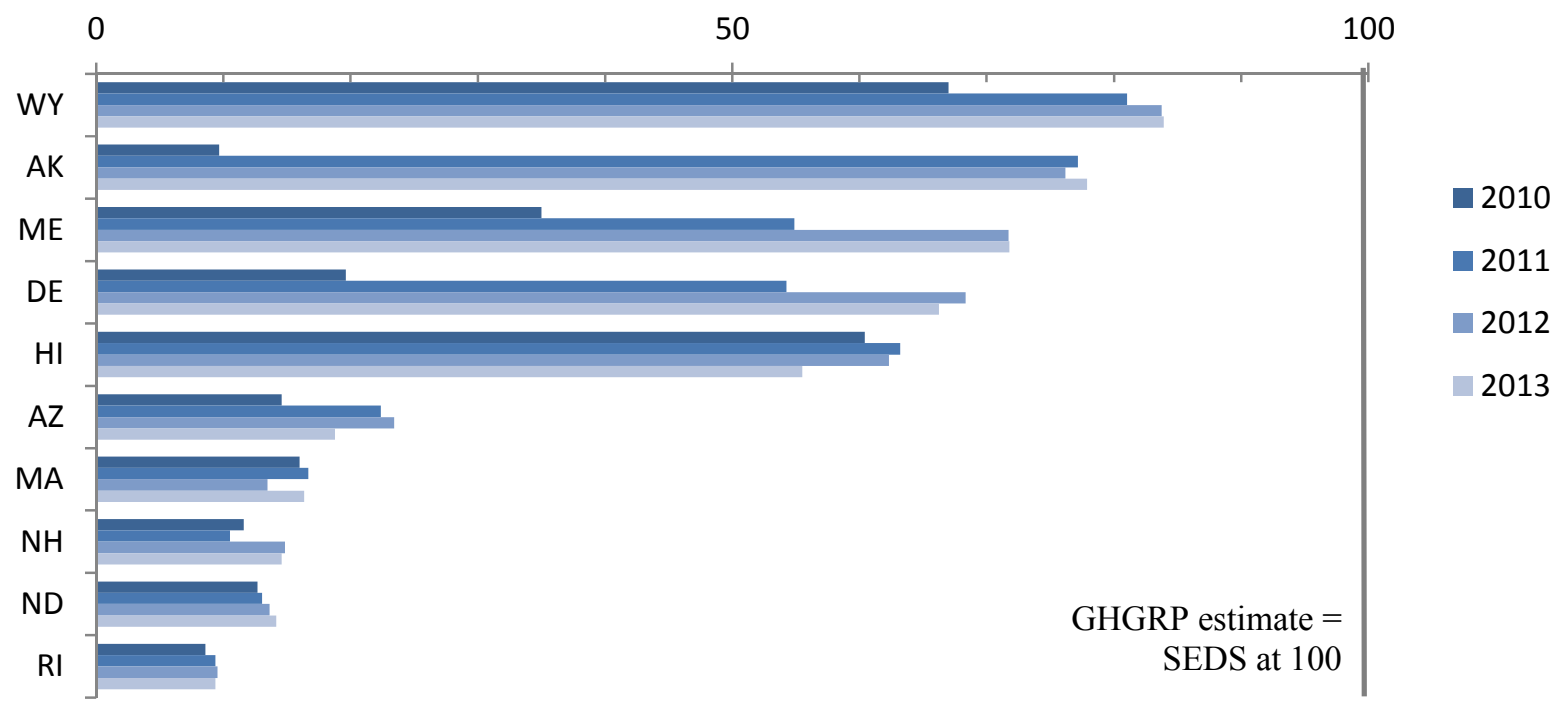

Figure 7. Relative comparison of industrial-sector combustion energy use reported by EIA SEDS and calculated from GHGRP GHG emissions data for selected states

One of the most notable differences between energy use estimated from GHGRP data and existing EIA sources is the availability of facility-level information, including facility location provided by latitude and longitude coordinates. GHGRP data allow inter-facility comparisons of GHG emissions and estimated combustion energy use. For example, Figure 8 shows the cumulative distribution of combustion energy use for iron and steel facilities. Of the 115 facilities reporting in 2014 , about $90 \%$ are estimated to have used less than 10,000 $\mathrm{TJ} /$ year $(9.48$ TBtu/year) of combustion fuels.

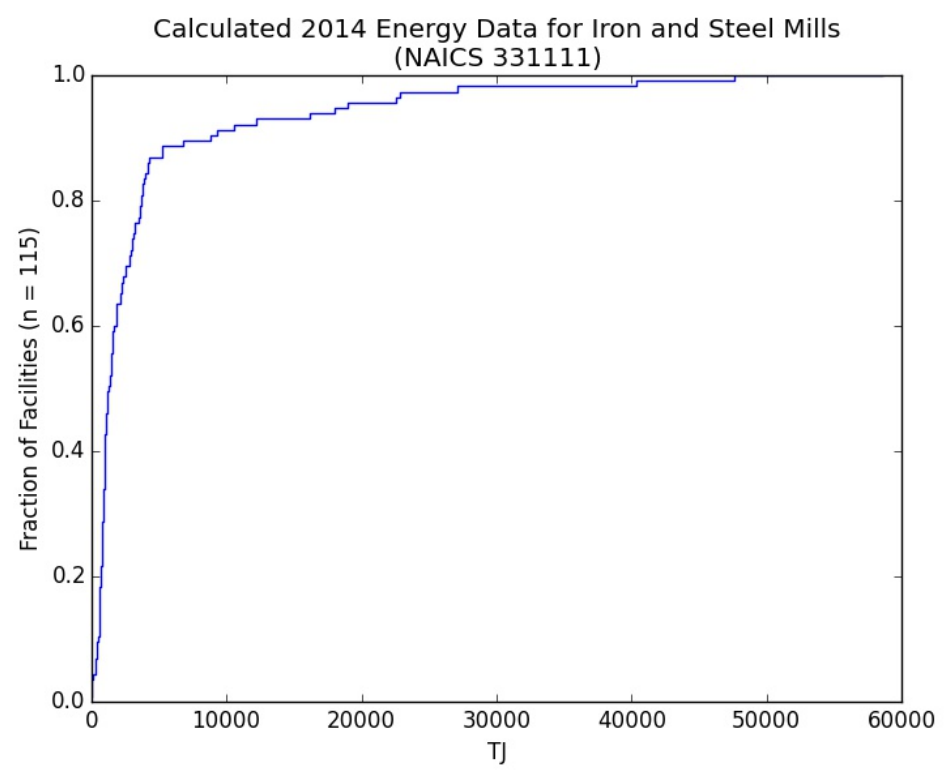

Figure 8. Cumulative distribution of calculated combustion energy use for iron and steel facilities in 2014

Estimated energy can also be broken down by fuel type. The results shown in Figure 9 indicate that natural gas is the largest source of combustion energy for the target industries. 


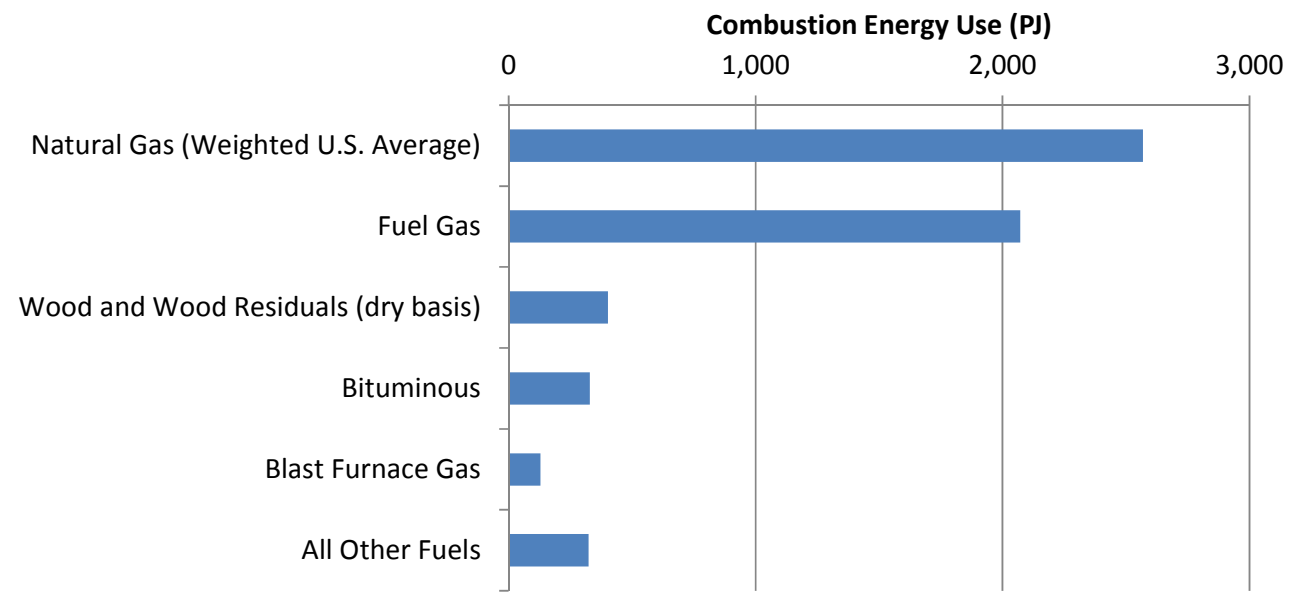

Figure 9. Calculated combustion energy use by fuel type in 2014 for target industries (PJ)

\subsubsection{Calculated Industrial Energy by End Use}

Although the breakdown of energy use by fuel identifies one aspect of how industrial facilities meet their thermal demands, GHGRP contains additional data that provide an initial indication of what thermal demands are ultimately being met. GHGRP reporters specify the type of combustion unit that is associated with fuel use and GHG emissions. These combustion unit types include $\mathrm{CH}$ (comfort heater), C (calciner), MWC (municipal waste combustor), and RTO (regenerative thermal oxidizer). All told, 38 combustion unit types were reported in 2014. This data field has limited utility, however, because nearly $60 \%$ of estimated energy in 2014 is designated as OCS (other combustion source).

Table 4 summarizes the reported combustion-unit types for each of the target industries. Although 35 out of the 38 total unit types are reported by these industries, the seven types shown represent $90 \%$ of the calculated total combustion energy for the industries. The sum of each row indicates the share of industry energy use captured by the seven combustion unit types, which ranges from as low as $47 \%$ for potash, soda, and borate mining to as high as $100 \%$ for nitrogenous fertilizer manufacturing. The final row shows the combustion-unit type share of total energy for all target industries. As expected, the OCS combustion-unit type is dominant, although it represents less than $25 \%$ of calculated energy for alkalies and chlorine manufacturing, paperboard mills, and pulp mills. 
Table 4. Combustion-Unit Type Share of 2014 Calculated Combustion Energy Use by Target Industry

\begin{tabular}{|c|c|c|c|c|c|c|c|c|c|}
\hline Subsector & $\begin{array}{l}\text { Target } \\
\text { Industry }\end{array}$ & $\begin{array}{l}\text { Turbine, } \\
\text { Combined } \\
\text { Cycle (\%) }\end{array}$ & $\begin{array}{l}\text { Furnace } \\
(\%)\end{array}$ & $\begin{array}{l}\text { Boiler, } \\
\text { Other } \\
(\%)\end{array}$ & $\begin{array}{l}\text { Other } \\
\text { Combustion } \\
\text { Source (\%) }\end{array}$ & $\begin{array}{l}\text { Process } \\
\text { Heater } \\
(\%)\end{array}$ & $\begin{array}{l}\text { Stoker } \\
\text { Boiler } \\
(\%)\end{array}$ & $\begin{array}{l}\text { Electricity } \\
\text { Generator } \\
(\%)\end{array}$ & $\begin{array}{l}\text { Industry } \\
\text { Total } \\
\text { Share } \\
(\%)\end{array}$ \\
\hline $\begin{array}{l}\text { Petroleum and } \\
\text { Coal Products } \\
\text { Manufacturing }\end{array}$ & $\begin{array}{l}\text { Petroleum } \\
\text { Refineries }\end{array}$ & 1 & & 9 & 65 & 18 & & 5 & 99 \\
\hline $\begin{array}{l}\text { Primary Metal } \\
\text { Manufacturing }\end{array}$ & $\begin{array}{l}\text { Iron and Steel } \\
\text { Mills }\end{array}$ & & 3 & 14 & 77 & 6 & & & 99 \\
\hline \multirow{3}{*}{$\begin{array}{l}\text { Paper } \\
\text { Manufacturing }\end{array}$} & $\begin{array}{l}\text { Paper (except } \\
\text { Newsprint) } \\
\text { Mills }\end{array}$ & 2 & & 20 & 29 & & 28 & & 80 \\
\hline & $\begin{array}{l}\text { Paperboard } \\
\text { Mills }\end{array}$ & 2 & & 29 & 14 & & 37 & & 82 \\
\hline & Pulp Mills & & & 23 & 15 & & 51 & & 90 \\
\hline \multirow{6}{*}{$\begin{array}{l}\text { Chemical } \\
\text { Manufacturing }\end{array}$} & $\begin{array}{l}\text { All Other } \\
\text { Basic Organic } \\
\text { Chemical } \\
\text { Manufacturing }\end{array}$ & 17 & 6 & 10 & 43 & 3 & 1 & 18 & 97 \\
\hline & $\begin{array}{l}\text { Ethyl Alcohol } \\
\text { Manufacturing }\end{array}$ & & & 4 & 93 & & & & 97 \\
\hline & $\begin{array}{l}\text { Plastics } \\
\text { Material and } \\
\text { Resin } \\
\text { Manufacturing }\end{array}$ & 4 & 14 & 7 & 53 & & 3 & 2 & 84 \\
\hline & $\begin{array}{l}\text { Petrochemical } \\
\text { Manufacturing }\end{array}$ & 4 & 24 & 11 & 39 & 14 & & & 93 \\
\hline & $\begin{array}{l}\text { Alkalies and } \\
\text { Chlorine } \\
\text { Manufacturing }\end{array}$ & 12 & 1 & 4 & 21 & & & 29 & 67 \\
\hline & $\begin{array}{l}\text { Nitrogenous } \\
\text { Fertilizer } \\
\text { Manufacturing }\end{array}$ & & & 10 & 86 & 3 & & & 100 \\
\hline $\begin{array}{l}\text { Food } \\
\text { Manufacturing }\end{array}$ & $\begin{array}{l}\text { Wet Corn } \\
\text { Milling }\end{array}$ & & & 1 & 56 & & 2 & & 59 \\
\hline $\begin{array}{l}\text { Nonmetallic } \\
\text { Mineral } \\
\text { Product } \\
\text { Manufacturing }\end{array}$ & $\begin{array}{l}\text { Lime } \\
\text { Manufacturing }\end{array}$ & & & & 49 & & & & 49 \\
\hline \multirow[t]{2}{*}{$\begin{array}{l}\text { Mining (Except } \\
\text { Oil and Gas) }\end{array}$} & $\begin{array}{l}\text { Potash, Soda, } \\
\text { and Borate } \\
\text { Mineral } \\
\text { Mining }\end{array}$ & & & 4 & 32 & & 10 & & 47 \\
\hline & $\begin{array}{l}\text { Fraction of } \\
\text { All Target } \\
\text { Industries } \\
(\%)\end{array}$ & 3 & 3 & 11 & 55 & 8 & 6 & 5 & \\
\hline
\end{tabular}

Note: null values not shown in order to improve readability.

To overcome the limitation of the OCS designation, we applied end-use consumption data from EIA MECS to calculated energy-use data based on reported six-digit NAICS code and fuel type. 
Note that MECS is conducted only for manufacturing industries (NAICS 31-33), whereas GHGRP industrial reporters include non-manufacturing industries associated with agriculture and mining. ${ }^{16}$ If an industry was not reported in MECS at the six-digit NAICS code level, it was matched to the next-most-detailed reporting level. For example, a facility that reports under the GHGRP and identifies as a "frozen fruit, juice, and vegetable manufacturer" (NAICS 311411) is matched to MECS end-use data for "fruit and vegetable preserving and specialty food manufacturing" (NAICS 3114). MECS data that were missing, withheld, or identified as "End Use Not Reported" were adjusted following the assumptions and methods described by Fox et al. (2011).

The summation of end-use energy for the target industries (excluding potash, soda, and borate mineral mining) calculated using MECS data is shown in Table $5 .{ }^{17}$ The calculations indicate that the majority of energy from fuel combustion is used in boilers, either for conventional boilers or for combined heat and power (CHP)/cogeneration. The second-largest end use is direct process heating, which accounts for $24 \%$ of calculated energy use, followed by various other direct process uses and direct non-process uses.

\footnotetext{
${ }^{16}$ It was not possible to calculate end-use energy for the potash, soda, and borate mineral mining industry because the industry is not included in MECS.

${ }^{17}$ Several facilities reported use of fuel types that are not included in MECS for the matching industry. As a result, the energy use associated with these fuels does not appear in the end use categories. This unallocated energy amounts to about $3 \%$ of the total calculated energy use of manufacturing industries reporting to the GHGRP in 2014.
} 
Table 5. Calculated Target Industry Energy by End Use in 2014

\begin{tabular}{|c|c|c|}
\hline End Use & $\begin{array}{l}\text { Calculated } \\
\text { Energy Use in PJ } \\
\text { (TBtu) }\end{array}$ & $\begin{array}{l}\text { Share of Calculated } \\
\text { Energy Use }(\%)\end{array}$ \\
\hline \multicolumn{3}{|l|}{ Indirect Uses-Boiler Fuel } \\
\hline Conventional Boiler Use & $1,855(1,758)$ & 32 \\
\hline CHP and/or Cogeneration Process & $2,143(2,031)$ & 37 \\
\hline Total & $3,998(3,789)$ & 70 \\
\hline \multicolumn{3}{|l|}{ Direct Uses-Total Process } \\
\hline Process Heating & $1,366(1,295)$ & 24 \\
\hline Process Cooling and Refrigeration & $17(16)$ & 0.3 \\
\hline Machine Drive & $174(165)$ & 3 \\
\hline Electrochemical Processes & $0.3(0.28)$ & 0.0 \\
\hline Other Process Use & $76(72)$ & 1 \\
\hline Total & $1,633(1,548)$ & 28 \\
\hline \multicolumn{3}{|l|}{ Direct Uses-Total Non-Process } \\
\hline Facility HVAC (g) & $28(27)$ & 0.5 \\
\hline Facility Lighting & $1(1)$ & 0.0 \\
\hline Other Facility Support & $5(5)$ & 0.1 \\
\hline Onsite Transportation & $2(2)$ & 0.0 \\
\hline Conventional Electricity Generation & $15(14)$ & 0.3 \\
\hline Other Non-Process Use & $2(2)$ & 0.0 \\
\hline Total & $54(51)$ & 1 \\
\hline
\end{tabular}

Note: Absolute and relative energy by end use may not sum due to rounding.

End-use calculations on an individual industry level are summarized in Figure 10, which identifies the most significant end uses for each industry. The figure also depicts the calculated energy by end use for all individual facilities that constitute the 169 remaining manufacturing industries reporting to the GHGRP in 2014, indicated by the "All Other" category. The end-use proportions for "All Other" were calculated based on the sum of calculations performed on these individual facilities. These results provide a foundation for more detailed, process-level analysis of industrial thermal demands presented in subsequent sections of the report. 


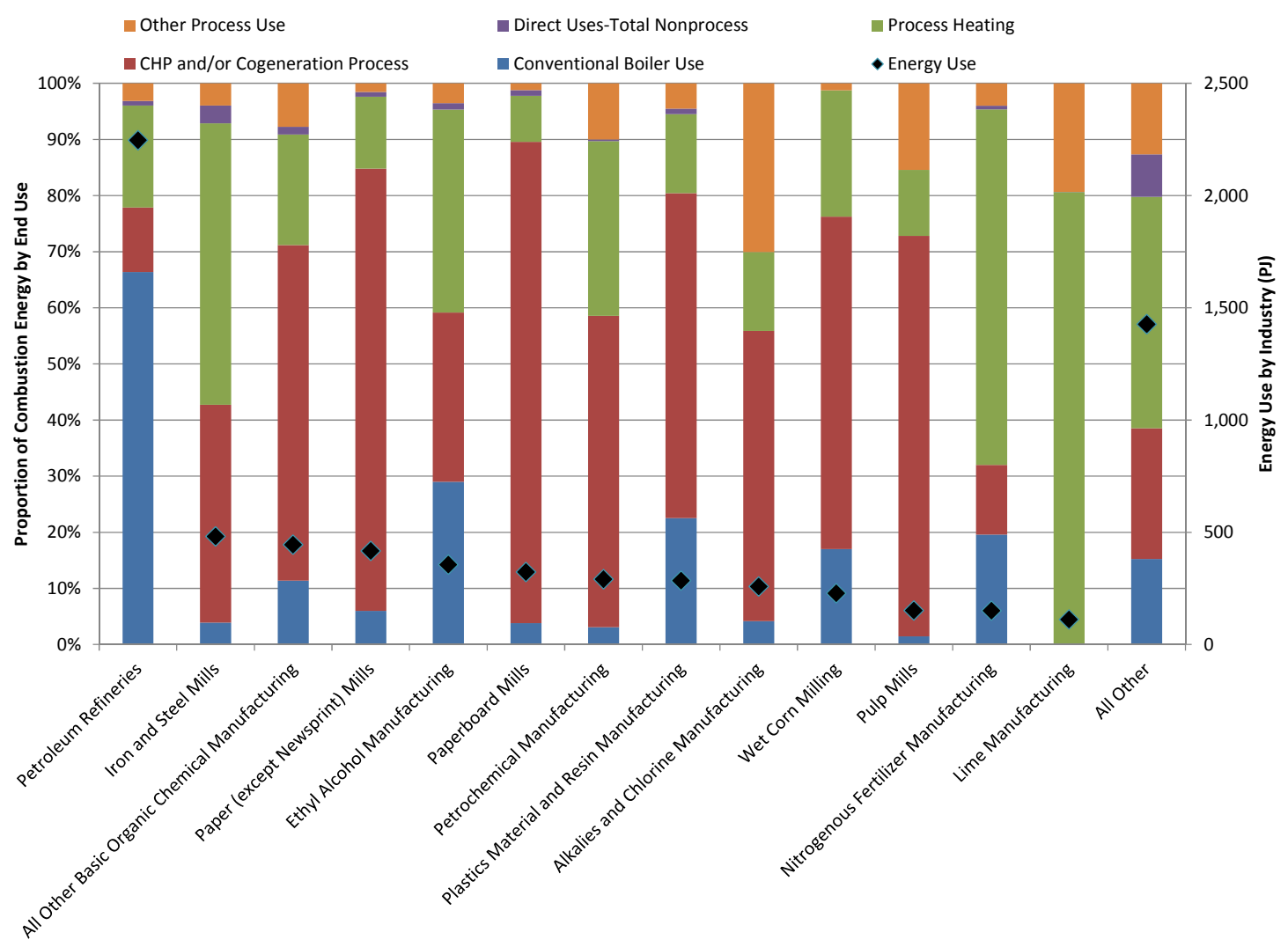

Figure 10. Calculated combustion energy by end use and target industry in 2014

Note: CHP and/or cogeneration energy use does not account for electricity generation losses. A larger version of this figure is included as Appendix $B$.

By combining MECS data with energy estimates based on GHGRP data, it is possible to approximate the geographic distribution of the target industries and their thermal-energy end uses by industry at a much finer resolution that what was previously possible using publicly available data. Figure 12 through Figure 15 map the relative density of thermal energy by end use (i.e., total thermal, conventional boiler, direct process, and cogeneration) for the target industries. The most intensive use occurs in the Gulf Coast region of Texas and Louisiana, which is the area with the largest concentration of petroleum refining, petrochemical manufacturing, and other basic organic chemical manufacturing. Other significant areas of concentrated thermalenergy use are found in the Chicago, Philadelphia, and Los Angeles metropolitan areas. A moderate concentration of process thermal energy is spread throughout Iowa and surrounding states, which corresponds to the locations of ethyl alcohol manufacturing facilities. It is also instructive to note the areas where the target industries are not located, namely, the western interior of the country. 


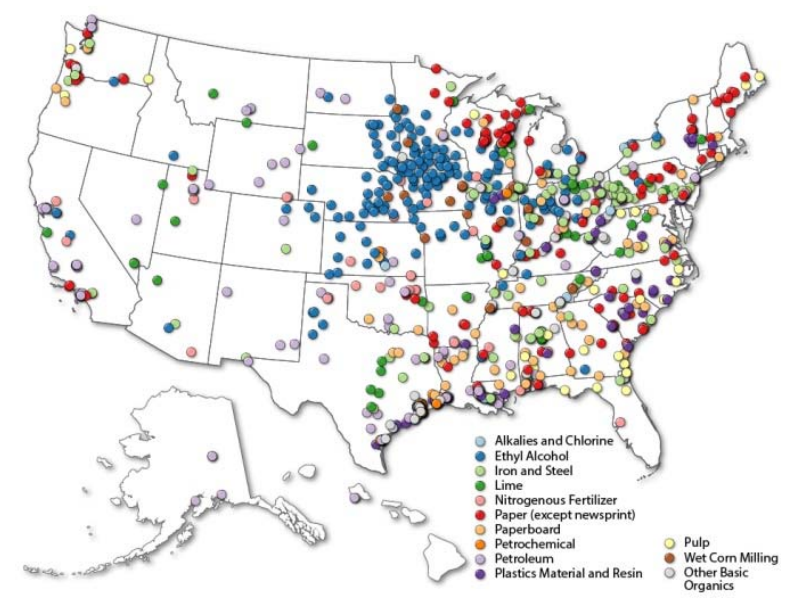

Figure 11. Facility location by target industry

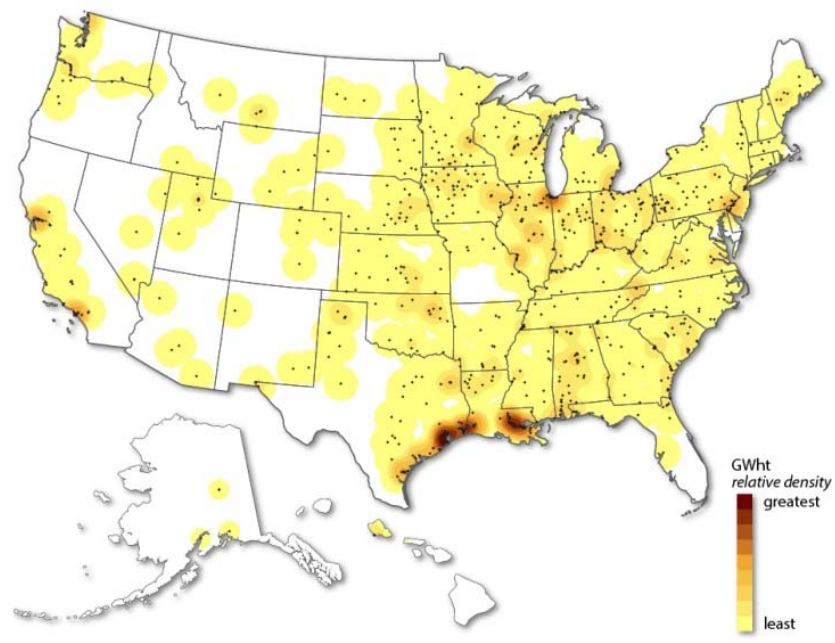

Figure 12. Distribution of target industry total thermal-energy use

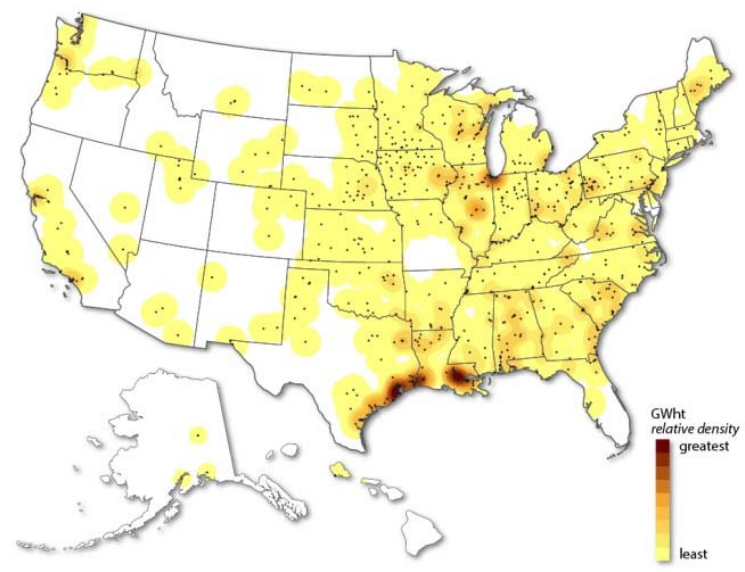

Figure 13. Distribution of target industry thermal energy for cogeneration use 


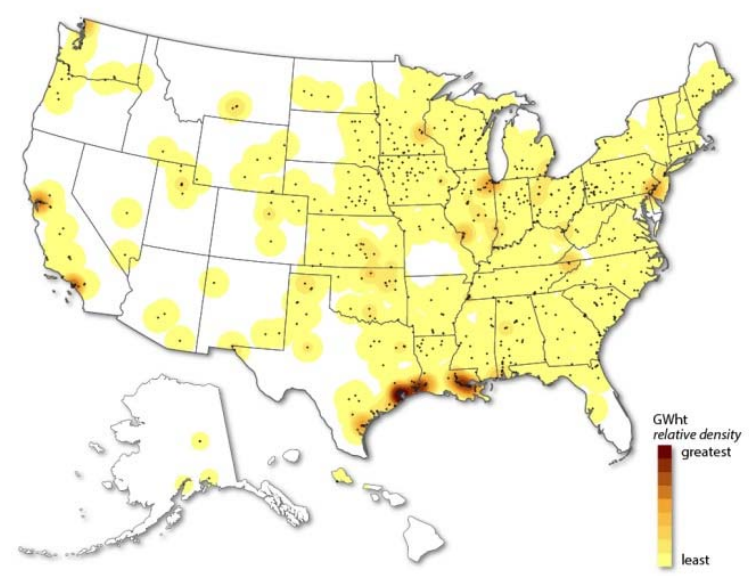

Figure 14. Distribution of target industry thermal energy for conventional boiler use

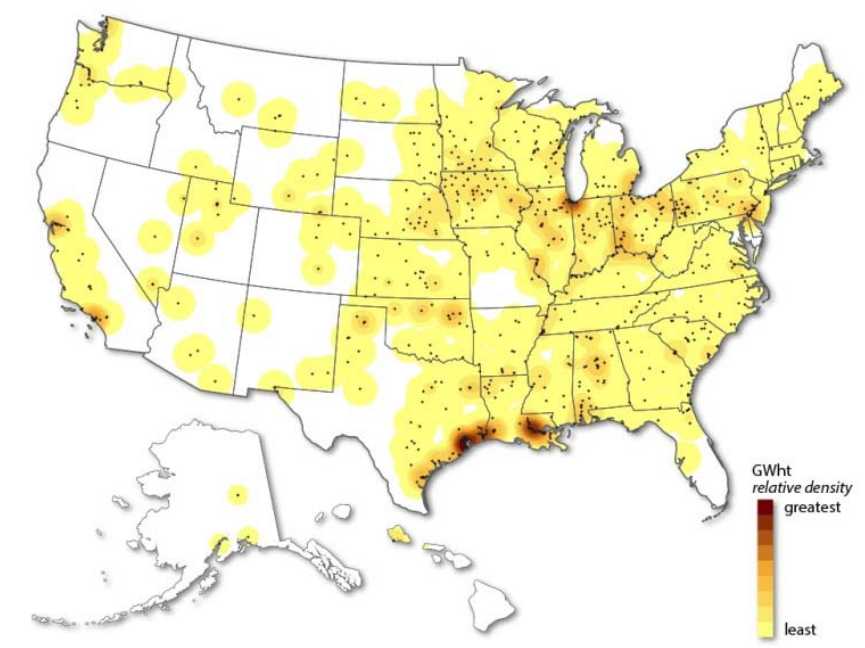

Figure 15. Distribution of target industry thermal energy for direct process use

\subsubsection{Energy for Combined Heat and Power/Cogeneration}

Table 6 indicates that $37 \%$ of calculated target industry energy use is for CHP and/or cogeneration. Given its significance as an energy end use and the multiple ways of allocating GHG emissions (WRI/WBCSD 2006), it is important to accurately account for combustion fuel energy used for $\mathrm{CHP} /$ cogeneration. We supplemented existing $\mathrm{CHP} /$ cogeneration energy estimates from EIA MECS with facility-level estimates calculated from GHGRP data.

GHGRP reporters indicate whether emissions include emissions from CHP or cogeneration units. Using this designation, as well as information on the reported combustion-unit type, we calculated estimates of the absolute and relative amounts of combustion energy used for onsite electricity generation. Specifically, fuel use was summed for cogeneration-designated facilities that have indicated combined-cycle turbines, simple-cycle combustion turbines, or electricity generator combustion-unit types. Estimates of the fraction of total combustion energy used for $\mathrm{CHP} /$ cogeneration are shown by industry in Table 6. CHP/cogeneration fractions estimated from adjusted MECS end-use data are provided for reference. In all industries except alkalies and chlorine manufacturing, the fraction of CHP/cogeneration calculated from GHGRP data is substantially lower than the value provided by EIA MECS. 
The estimates calculated from GHGRP data can be thought of as lower bounds of the combustion energy used for onsite electricity generation. Given the large fraction of combustion units identified as OCS (other combustion source), it is likely that some facilities reporting emissions from a cogeneration unit and indicating the combustion-unit type as OCS are actually reporting fuel use associated with $\mathrm{CHP} /$ cogeneration. The energy use of these facilities is not captured as energy use for $\mathrm{CHP} /$ cogeneration as a result. Conversely, it is less likely that reporters misidentified either their designation of emissions resulting from $\mathrm{CHP} /$ cogeneration or their combustion-unit type. Also note that adjusting MECS data using the assumptions and method of Fox et al. (2011) for many industries allocates energy without a reported end use and energy associated with byproducts (e.g., wood chips, blast furnace/coke oven gases, and waste gases) to $\mathrm{CHP} /$ cogeneration end use. The adjustments were also made based on the less detailed three-digit NAICS code level rather than the six-digit NAICS code level used for reporting combustion-unit type.

Table 6. Estimated Fraction of Combustion Energy Used for CHP/Cogeneration

\begin{tabular}{|c|c|c|c|c|}
\hline Industry Subsector & Target Industry & $\begin{array}{l}\text { NAICS } \\
\text { Code }\end{array}$ & $\begin{array}{l}\text { Fraction of } \\
\text { Combustion } \\
\text { Energy Used for } \\
\text { CHP/Cogeneration } \\
\text { (GHGRP Data) }\end{array}$ & $\begin{array}{l}\text { Fraction of } \\
\text { Combustion } \\
\text { Energy Used for } \\
\text { CHP/Cogeneration } \\
\text { (Adjusted MECS } \\
\text { Data) }\end{array}$ \\
\hline $\begin{array}{l}\text { Petroleum and } \\
\text { Coal Products }\end{array}$ & Petroleum Refineries & 324110 & 0.07 & 0.12 \\
\hline Primary Metals & Iron and Steel Mills & 331111 & 0.00 & 0.29 \\
\hline \multirow{3}{*}{$\begin{array}{l}\text { Paper } \\
\text { Manufacturing }\end{array}$} & $\begin{array}{l}\text { Paper (except } \\
\text { Newsprint) Mills }\end{array}$ & 322121 & 0.03 & 0.85 \\
\hline & Paperboard Mills & 322130 & 0.02 & 0.89 \\
\hline & Pulp Mills & 322110 & 0.00 & 0.93 \\
\hline \multirow{6}{*}{$\begin{array}{l}\text { Chemical } \\
\text { Manufacturing }\end{array}$} & $\begin{array}{l}\text { All Other Basic Organic } \\
\text { Chemical } \\
\text { Manufacturing }\end{array}$ & 325199 & 0.34 & 0.53 \\
\hline & $\begin{array}{l}\text { Ethyl Alcohol } \\
\text { Manufacturing }\end{array}$ & 325193 & 0.00 & 0.32 \\
\hline & $\begin{array}{l}\text { Plastics Material and } \\
\text { Resin Manufacturing }\end{array}$ & 325211 & 0.08 & 0.54 \\
\hline & $\begin{array}{l}\text { Petrochemical } \\
\text { Manufacturing }\end{array}$ & 325110 & 0.07 & 0.35 \\
\hline & $\begin{array}{l}\text { Alkalies and Chlorine } \\
\text { Manufacturing }\end{array}$ & 325181 & 0.73 & 0.54 \\
\hline & $\begin{array}{l}\text { Nitrogenous Fertilizer } \\
\text { Manufacturing }\end{array}$ & 325311 & 0.00 & 0.13 \\
\hline $\begin{array}{l}\text { Food } \\
\text { Manufacturing }\end{array}$ & Wet Corn Milling & 311221 & 0.00 & 0.52 \\
\hline Nonmetallic & Lime Manufacturing & 327410 & 0.00 & 0.00 \\
\hline
\end{tabular}




\begin{tabular}{|c|c|c|c|c|}
\hline Industry Subsector & Target Industry & $\begin{array}{l}\text { NAICS } \\
\text { Code }\end{array}$ & $\begin{array}{l}\text { Fraction of } \\
\text { Combustion } \\
\text { Energy Used for } \\
\text { CHP/Cogeneration } \\
\text { (GHGRP Data) }\end{array}$ & $\begin{array}{l}\text { Fraction of } \\
\text { Combustion } \\
\text { Energy Used for } \\
\text { CHP/Cogeneration } \\
\text { (Adjusted MECS } \\
\text { Data) }\end{array}$ \\
\hline \multicolumn{5}{|l|}{$\begin{array}{l}\text { Mineral Product } \\
\text { Manufacturing }\end{array}$} \\
\hline $\begin{array}{l}\text { Mining (Except Oil } \\
\text { and Gas) }\end{array}$ & $\begin{array}{l}\text { Potash, Soda, and } \\
\text { Borate Mineral Mining }\end{array}$ & 212391 & 0.00 & No data \\
\hline
\end{tabular}

\subsection{Conclusions}

Analysis of 2014 GHGRP data revealed 14 industries that were selected for process-level analysis. The direct-combustion emissions of the 960 facilities in these industries collectively constitute nearly one-quarter of industrial-sector emissions - equivalent to $5 \%$ of U.S. total emissions in 2014. End-use calculations for the target industries indicate that the majority of energy from fuel combustion is used in boilers, either for conventional boilers or for $\mathrm{CHP} /$ cogeneration. The second-largest end use is direct process heating, which accounts for $24 \%$ of calculated energy use, followed by various other direct process uses and direct non-process uses. Alternate calculations of $\mathrm{CHP} /$ cogeneration end use were performed, but their usefulness is limited by the accuracy of facility-reported combustion-unit type. 


\section{APPLICATION OF THERMAL ENERGY IN INDUSTRY}

The aim of this section is to address applications of heat transfer in the target industries and how clean energy inputs can replace heat that is traditionally produced by burning carbon-containing fuels. The discussion of each industry provides a complement to existing Department of Energy (DOE) resources on industrial heat (e.g., DOE 2016; DOE 2015b; DOE 2015c; DOE 2015d; Thekdi and Nimbalkar 2014). The common feature of the target industries is that they convert raw materials into energy services by means of physical and chemical changes through a series of process steps. These changes generally require thermal energy to affect solids and liquids heat-up, melting, and evaporation. Thermal energy is also needed to heat up reactants to initiate molecular bond breaking and to sustain the propagation of endothermic reactions and even slightly exothermic reaction mechanisms that are easily curtailed by chain-termination reaction steps. Thermodynamic considerations necessitate operation of many chemical processes at the highest temperature possible, even with the aid of catalysts, to attain high conversion efficiencies and to reduce reactor-vessel sizes. In the case of highly exothermic reactions, including synthesis of many organic molecules, heat must be removed to manage reaction efficiency, product volatility, or to avoid reactor-materials degradation. Electrochemical and electrocatalysis processes may reduce the thermal duty of chemical conversion processes; consequently, interest in developing process steps based on electrochemistry is on the rise with advances in materials science and nanotechnology and the advent of effective solar PV energy (Botte, 2014). Heat deposition by electromagnetic heat transfer, such as infrared heating, may also enhance process intensification and deep decarbonization.

Thermal energy differs from electrical and chemical energy to the extent that high-grade heat cannot be cost-effectively delivered over long distances without significant heat loss or expensive pipe insulation and/or double-wall air-gap pipe. Very high-temperature gases $\left(>750^{\circ} \mathrm{C}\right)$ further require a corrosion-resistant alloy or refractory lining. Fluid compressors, pumps, and control valves must be compatible with the heat-transfer fluid (or media). Pipe runs must be built to handle thermal-expansion stresses during process start-up and shut-down, intermittent operation, and unplanned disruptions in flow conditions.

In summary, in addition to cost, heat-delivery and heat-transfer system design considerations include:

- Chemical-process considerations

- Temperature of reactor-unit operations

- Heat-rate requirements and profile (continuous or batch)

- Reaction regimes (gas/liquid/solid mixing and contact)

- Reactor design (fixed-bed, fluid-bed, entrained particles; well-stirred or plugflow)

- Mode of heat transfer (direct or indirect contact on heat-transfer fluid, convective or radiative).

- Heat transport, delivery, and process transfer considerations

- Distance of heat source to multiple-unit operations or multiple plants 
- Heat-transfer fluid (physical and thermodynamic properties and rheology)

○ Heat-loss control

- Heat-exchanger design

- Safety (chemical toxicity and radioactivity)

- Corrosion and erosion of heat-transfer materials and flow motive and control equipment.

Chemical-process considerations are later identified in Table 8 of this section for the major thermal demands for each target industry. Heat transport, delivery, and process transfer considerations are discussed in detail in Section 4.

\subsection{Chemical Process Heat Utilization}

Heat input drives at least one or more process steps for the majority of the chemical conversion processes, as demonstrated by the major chemical and biological reactor processes highlighted in this report. Many of the process steps employ indirect heating:

- Fermentation

- Pasteurization and purification

- Drying and evaporation, e.g., distillation

- Desorption

- Solids melting

- Dehydrogenation

- Chemical purification and separation

- Thermal cracking

- Hydrothermal cracking and hydrothermal treatment of large organic molecules

- Endothermic process steps of steam-methane reforming

- Depolymerization and organic molecule scissioning.

Some processes steps combine in-situ chemical-reactor heat generation and direct contact with chemical conversion reactions that generate heat and add reactant species to the unit operation:

- Auto-thermal steam-methane reforming

- Smelting and calcining ores

- Coke production for iron making; and iron ore smelting by iron reduction

- Alloying of metals, metals purification and annealing

- Glass production

- Refractories production and firing of ceramics and coatings. 
Many processes for industries identified in this report involve heating in multi-tubular gas flow reactors, trickle-bed tubular reactors, and agitated liquid vessels. An outside jacket, external limpet coil, or internal tube coil is employed to transfer heat from steam or hot gas (from a fired heater) to these chemical reactors. Because the flow through the jacket or coils depends on the position of inlet and outlet connections, substitution of hot gas, liquid metals, or molten salt for steam can be effective if the substitution provides equivalent or better heat-transfer rates. Assessment of the heat capacity of the substitute fluids, their heat-transfer coefficients and rheological properties, heat jacket or coils material compatibility, and changes in mechanical stresses can be considered.

Solids-handling chemical reactors include fluidized beds, rotary drums and rotary/sheeted drum, and horizontal rotary-driven/mixing ribbon/spiral reactors. These reactors are usually heated with steam and hot-gas jackets or direct contact with steam and hot gas directed into the reactor vessel. In the case of lime and cement production (rotary kiln), iron making (open hearth), and glass production (floated ribbon surface), very high temperatures are realized with in-situ/overfire combustion, exploiting radiation and convective heat transfer to decompose the solid material or to burn out impurities. Reactant feed streams are often preheated using a jacket heat exchanger that recuperates heat from the effluent gases and solid products.

Thermodynamic efficiency and kinetic considerations typically require plant operation at high temperatures to achieve high production rates and to reduce plant size. For any chemical reaction to occur, its change in Gibbs free energy, $\Delta \mathrm{G}$, in going from reactants to products must be negative, where higher conversion efficiency is achieved as $\Delta \mathrm{G}$ becomes more negative. This quantity is defined as:

$$
\Delta \mathrm{G}=\Delta \mathrm{H}-\mathrm{T} \Delta \mathrm{S}
$$

where $\Delta \mathrm{H}$ is the change in enthalpy, $\mathrm{T}$ is temperature, and $\Delta \mathrm{S}$ is the change in entropy. For most reactions, a negative $\Delta \mathrm{G}$ is obtained by having a negative $\Delta \mathrm{H}$. Reactions that require heat addition have a positive $\Delta \mathrm{H}$ and by convention are referred to as being endothermic. In that situation, to obtain the negative $\Delta \mathrm{G}$ that allows a reaction to proceed, $\Delta \mathrm{S}$ must be positive. In most cases, a positive $\Delta \mathrm{S}$ is a consequence of larger molecules being broken down into several smaller ones (for instance, the conversion of methane and water into a mixture of carbon monoxide and hydrogen molecules). Synthesizing more complex molecules from simple feeds generally has a negative entropy change. Even when the entropy change is positive, $\Delta \mathrm{S}$ is usually small, so the absolute temperature T must be large in order to promote the desired reaction.

About $40 \%$ of energy delivered to conventional chemical plants is by steam loops (DOE 2016), where steam is produced and superheated by a package/combustion-fired/tube boiler or by hot gases that are produced by combustion, including the combustor effluent itself or a heating coil if an inert gas or an intended reactant gas is required. Although the amount of steam needed varies greatly depending on the process, its magnitude can usually be estimated. For example, the heat required to boil octane, a typical organic compound of petroleum distillate, is about $300 \mathrm{~kJ} / \mathrm{kg}$ $(130 \mathrm{Btu} / \mathrm{lb})$. Assuming that the process streams pass through five distillation steps, each with a 
reflux ratio of five, ${ }^{18}$ a total of $2.6 \mathrm{MJ} / \mathrm{kg}(5,400 \mathrm{Btu} / \mathrm{lb})$ of heat is required to fractionate petroleum feed into its respective distillate fractions.. Regardless of the heat demand in the primary organic synthesis reaction(s), separation and purification of the reaction products can also consume a large amount of heat as steam.

The low cost and high volume/energy density of fossil fuels has been a major factor in the design of almost all conventional industrial processes. Replacement of combustion gases with a clean heat source or electrification of the process-unit operations, in combination with substitution of fossil fuels with hydrogen produced by nuclear and renewable energy sources, can accelerate deep reduction of $\mathrm{CO}_{2}$ emissions.

In practice, the temperatures of reactions that absorb heat such as dehydrogenation of butylenes to butadiene $\left(600-800^{\circ} \mathrm{C}\right)$, steam methane reforming $\left(800-900^{\circ} \mathrm{C}\right)$, or lime production $(900$ $1,200^{\circ} \mathrm{C}$ ) are well above the heat level that is available from light-water reactors and are above most high-temperature nuclear-reactor operating temperatures (Pitzer 1972; Wood 2010; Eggeman, Lime and Limestone 2010). For example, future high temperature reactors under development within the GEN IV nuclear reactor program may reach temperatures between $550^{\circ} \mathrm{C}-1000^{\circ} \mathrm{C}$ and could be used to provide heat to some of the higher temperature industrial processes (Locatelli 2013). Therefore, new heat-integration schemes, including topping heat, can enable full advantage of nuclear heat sources. Understanding the selection and optimization of heat-exchange processes is important to understanding how to effectively integrate clean heat sources within existing plant designs. In practice, determining options for heat integration is supported by exergy destruction analysis, which can be understood through matching composite stream temperature-enthalpy curves and performing pinch analysis to design heat-exchanger networks for a given plant (Hewitt et al. 1994).

\subsection{Assessment of Industry Thermal Energy Use}

The appendices to this report provide detailed material and energy-use rates for major process plants representing each key industry among each of these sectors. Although the selected plants represent only one-fourth of the U.S. industrial energy use (5,823 PJ [5,520TBtu] total), they are representative of the majority of Chemicals, Petroleum Refining, Forest Products, Food and Beverage, Iron \& Steel, and Remaining Manufacturing industries. Table 7 identifies the total number of plants for each of these categories, the total energy usage for all plants, average plant energy-use rates, and thermal characteristics. Actual plant sizes can vary by a factor of $2-5$ times the average plant size.

Table 7 and Table 8 summarize data for selected industries. Table 7 is based on the number of plants reporting combustion GHG emissions to the GHGRP and their total production and emissions. Table 8 summarizes data gathered from a variety of sources including process flow sheets, detailed process descriptions, publications, and technical references. Detailed data for each selected process can be found in the appendices. The data were normalized based on the average plant combustion GHG emissions reported for each target industry, as summarized in Section 2. As a result of this normalization, the data in Table 7 and Table 8 may not match the data presented in the appendices for a particular industry or typical average facility.

\footnotetext{
${ }^{18}$ Reflux ratio is the amount of condensed overhead product returned to the column to be re-vaporized to increase the distillation performance expressed as a multiple of the amount removed as product.
} 
Table 7. Production and Emissions of Selected Industries Based on Sum Total of Facilities Reporting Combustion GHG Emissions ${ }^{19}$

\begin{tabular}{|c|c|c|c|c|c|c|}
\hline Industry Subsector & Target Industry & $\begin{array}{l}\text { Production } \\
\text { (tonnes/day) }\end{array}$ & $\begin{array}{l}\text { Number } \\
\text { of Plants }\end{array}$ & $\begin{array}{l}\text { Electricity } \\
\text { Usage (MW) }\end{array}$ & $\begin{array}{l}\text { Heat Input } \\
\text { in TJ/day } \\
\text { (TBtu/day) }\end{array}$ & $\begin{array}{c}\text { Emissions } \\
\text { (tonnes } \\
\mathrm{CO}_{2} \text { e/day) }\end{array}$ \\
\hline \multirow[t]{4}{*}{$\begin{array}{l}\text { Petroleum and Coal } \\
\text { Products }\end{array}$} & Petroleum Refineries & $\begin{array}{l}\text { Production } \\
\text { (bpd/day) }\end{array}$ & 141 & 2,558 & $\begin{array}{c}1,160 \\
(1.099)\end{array}$ & 339,493 \\
\hline & Gasoline & $4,769,807$ & & & & \\
\hline & Diesel & $1,797,319$ & & & & \\
\hline & Kerosene & 952,425 & & & & \\
\hline Primary Metal Manufacturing & Iron and Steel Mills & 69,345 & 115 & 14.1 & $278(0.264)$ & 139,630 \\
\hline \multirow[t]{4}{*}{ Paper Manufacturing } & Paper \& Paper-Board Mills & & & 4,556 & $\begin{array}{c}1,793 \\
(1.699)\end{array}$ & \\
\hline & Paper & 199,845 & 116 & & & 87,611 \\
\hline & Paper-Board & 323,200 & 73 & & & 65,708 \\
\hline & Pulp Mills & 14,223 & 30 & & $129(0.122)$ & 32,854 \\
\hline \multirow[t]{7}{*}{ Chemical Manufacturing } & $\begin{array}{l}\text { All other Basic Chemical } \\
\text { Manufacturing (Methanol) }\end{array}$ & 229,677 & 85 & 2,040 & $\begin{array}{c}1,096 \\
(1.039)\end{array}$ & 57,495 \\
\hline & Ethyl Alcohol Manufacturing & 10,695 & 168 & -266 & $297(0.282)$ & 49,281 \\
\hline & $\begin{array}{l}\text { Petrochemical Manufacturing } \\
\text { (Ethylene) }\end{array}$ & 93,268 & 35 & 2,465 & $\begin{array}{c}82.9 \\
(0.0786)\end{array}$ & 43,806 \\
\hline & Alkalies and Chlorine Manufacturing & & 11 & 2,492 & $\begin{array}{c}47.0 \\
(0.0445)\end{array}$ & 35,592 \\
\hline & Chlorine & 14,633 & & & $\begin{array}{c}0.177 \\
(0.000168)\end{array}$ & \\
\hline & Sodium Hydroxide & 12,777 & & & $\begin{array}{c}46.7 \\
(0.0443)\end{array}$ & \\
\hline & $\begin{array}{l}\text { Nitrogenous Fertilizer Manufacturing } \\
\text { (Ammonia) }\end{array}$ & 22,723 & 30 & 812 & $\begin{array}{c}211 \\
(0.200)\end{array}$ & 21,903 \\
\hline Food Manufacturing & Wet Corn Milling & & 24 & 314 & 193 & 49,281 \\
\hline
\end{tabular}

${ }^{19}$ Data in table normalized to industry combustion GHG emissions reported to EPA GHGRP in 2014. 


\begin{tabular}{|c|c|c|c|c|c|c|}
\hline Industry Subsector & Target Industry & $\begin{array}{l}\text { Production } \\
\text { (tonnes/day) }\end{array}$ & $\begin{array}{l}\text { Number } \\
\text { of Plants }\end{array}$ & $\begin{array}{l}\text { Electricity } \\
\text { Usage (MW) }\end{array}$ & $\begin{array}{l}\text { Heat Input } \\
\text { in TJ/day } \\
\text { (TBtu/day) }\end{array}$ & $\begin{array}{c}\text { Emissions } \\
\text { (tonnes } \\
\mathrm{CO}_{2} \mathrm{e} / \text { day) }\end{array}$ \\
\hline & & & & & $(0.183)$ & \\
\hline & Starch & 35,063 & & & & \\
\hline & Corn Gluten Feed & 14,243 & & & & \\
\hline & Corn Gluten Meal & 3,289 & & & & \\
\hline & Corn Oil & 2,200 & & & & \\
\hline \multirow{3}{*}{$\begin{array}{l}\text { Nonmetallic Mineral Product } \\
\text { Manufacturing }\end{array}$} & Lime \& Cement & & & & & \\
\hline & Lime & 24,863 & 49 & 62.6 & $\begin{array}{c}149 \\
(0.141)\end{array}$ & 27,379 \\
\hline & Cement & 234,000 & 117 & 1,615 & $1,100(1.04)$ & 444,600 \\
\hline Mining (Except Oil and Gas) & Soda Ash & 58,003 & 11 & 106 & $\begin{array}{c}286 \\
(0.271)\end{array}$ & 16,427 \\
\hline
\end{tabular}

bpd = barrels per day

Table 8. Production and Emissions from Average Plant of Selected Industries ${ }^{20}$

\begin{tabular}{|c|c|c|c|c|c|c|c|c|}
\hline $\begin{array}{l}\text { Industry } \\
\text { Subsector }\end{array}$ & Target Industry & $\begin{array}{l}\text { Production } \\
\text { (tonnes/day) }\end{array}$ & $\begin{array}{l}\text { Electricity } \\
\text { (MW) }\end{array}$ & $\begin{array}{l}\text { Heat Usage } \\
\text { in TJ/day } \\
\text { (MMBtu/day) }\end{array}$ & $\begin{array}{l}\text { Emissions } \\
\text { (tonnes } \\
\mathrm{CO}_{2} \mathrm{e} / \text { day) }\end{array}$ & $\begin{array}{c}\text { Process Heat Type/ } \\
\text { Purpose }\end{array}$ & $\begin{array}{l}\text { Chemical } \\
\text { Process }\end{array}$ & $\begin{array}{c}\text { Process Heat } \\
\text { Temperature } \\
\left({ }^{\circ} \mathrm{C}\right)\end{array}$ \\
\hline \multirow{4}{*}{$\begin{array}{l}\text { Petroleum } \\
\text { and Coal } \\
\text { Products }\end{array}$} & $\begin{array}{l}\text { Petroleum } \\
\text { Refineries }\end{array}$ & $\begin{array}{l}\text { Production } \\
\text { (bpd/day) }\end{array}$ & 18.1 & $8.23(7,800)$ & 2,408 & \multirow{4}{*}{$\begin{array}{l}\text { Gases from fired heater/ } \\
\text { Atmospheric crude } \\
\text { fractionator \& heavy } \\
\text { naphtha reformer }\end{array}$} & Continuous & 600 \\
\hline & Gasoline & 33,828 & & & & & & \\
\hline & Diesel & 12,747 & & & & & & \\
\hline & Kerosene & 6,755 & & & & & & \\
\hline $\begin{array}{l}\text { Primary Metal } \\
\text { Manufacturing }\end{array}$ & $\begin{array}{l}\text { Iron and Steel } \\
\text { Mills }\end{array}$ & 603 & 0.123 & 2.42 & 1,214 & $\begin{array}{l}\text { Combustion products / coke } \\
\text { production/ iron ore }\end{array}$ & $\begin{array}{l}\text { Batch } \\
\text { charge }\end{array}$ & 1,100 \\
\hline
\end{tabular}

${ }^{20}$ Data in table normalized to industry combustion GHG emissions reported to EPA GHGRP in 2014. 


\begin{tabular}{|c|c|c|c|c|c|c|c|c|}
\hline $\begin{array}{l}\text { Industry } \\
\text { Subsector }\end{array}$ & Target Industry & $\begin{array}{l}\text { Production } \\
\text { (tonnes/day) }\end{array}$ & $\begin{array}{l}\text { Electricity } \\
\text { (MW) }\end{array}$ & $\begin{array}{l}\text { Heat Usage } \\
\text { in TJ/day } \\
\text { (MMBtu/day) }\end{array}$ & $\begin{array}{c}\text { Emissions } \\
\text { (tonnes } \\
\mathrm{CO}_{2} \mathrm{e} / \mathrm{day} \text { ) }\end{array}$ & $\begin{array}{c}\text { Process Heat Type/ } \\
\text { Purpose }\end{array}$ & $\begin{array}{l}\text { Chemical } \\
\text { Process }\end{array}$ & $\begin{array}{c}\text { Process Heat } \\
\text { Temperature } \\
\left({ }^{\circ} \mathrm{C}\right)\end{array}$ \\
\hline & & & & $(2,290)$ & & reduction & & \\
\hline \multirow[t]{7}{*}{$\begin{array}{c}\text { Paper } \\
\text { Manufacturing }\end{array}$} & $\begin{array}{l}\text { Paper \& Paper- } \\
\text { Board Mills }\end{array}$ & & 53.6 & $\begin{array}{c}21.1 \\
(20,000)\end{array}$ & & $\begin{array}{l}\text { Steam / } \\
\text { drying }\end{array}$ & Continuous & 177 \\
\hline & Paper & 1,723 & & & 755 & & & \\
\hline & Paper-Board & 4,427 & & & 900 & & & \\
\hline & Pulp Mills & 474 & & $\begin{array}{c}4.32 \\
(4,100)\end{array}$ & 1,095 & $\begin{array}{c}\text { (90\% CHP with in-plant } \\
\text { black-liquor recovery } \\
\text { furnace) }\end{array}$ & & \\
\hline & & & & $\begin{array}{l}0.67 \\
(640)\end{array}$ & & $\begin{array}{l}\text { Combustion gases from } \\
\text { black liquor and waste } \\
\text { wood/lime kiln }\end{array}$ & Continuous & 800 \\
\hline & & & & $\begin{array}{c}1.15 \\
(1,090)\end{array}$ & & $\begin{array}{l}\text { Steam/heat to digester, } \\
\text { bleaching, oxygen stage, } \\
\text { multi-effect evaporator, } \\
\text { chemical preparation }\end{array}$ & Batch & 200 \\
\hline & & & & $\begin{array}{c}2.56 \\
(2,43)\end{array}$ & & $\begin{array}{l}\text { Steam/pulp machine, multi- } \\
\text { effect evaporator, chemical } \\
\text { preparation }\end{array}$ & Continuous & 150 \\
\hline \multirow[t]{4}{*}{$\begin{array}{l}\text { Chemical } \\
\text { Manufacturing }\end{array}$} & $\begin{array}{l}\text { All other Basic } \\
\text { Chemical } \\
\text { Manufacturing } \\
\text { (Methanol) }\end{array}$ & 2,702 & 24.0 & $\begin{array}{c}12.9 \\
(12,300)\end{array}$ & 676 & $\begin{array}{l}\text { Indirect heat from } \\
\text { combustion gases/ } \\
\text { primary reformer; } \\
\text { steam/ } \\
\text { methanol distillation }\end{array}$ & Continuous & 900 \\
\hline & \multirow[t]{3}{*}{$\begin{array}{l}\text { Ethyl Alcohol } \\
\text { Manufacturing }\end{array}$} & \multirow[t]{3}{*}{63.7} & \multirow[t]{3}{*}{-1.58} & \multirow[t]{3}{*}{$\begin{array}{c}1.76 \\
(1,670)\end{array}$} & 293 & $\begin{array}{c}\text { (In plant biomass residue } \\
\text { furnace } \mathrm{CHP} \text { ) } \\
\text { steam/ } \\
\text { pretreatment \& conditioning }\end{array}$ & $\begin{array}{l}\text { Continuous } \\
\text { or Batch }\end{array}$ & 266 \\
\hline & & & & & & $\begin{array}{c}\text { Steam / } \\
\text { distillation }\end{array}$ & $\begin{array}{l}\text { Continuous } \\
\text { or Batch }\end{array}$ & 233 \\
\hline & & & & & & $\begin{array}{c}\text { Steam / } \\
\text { power production }\end{array}$ & $\begin{array}{l}\text { Continuous } \\
\text { or Batch }\end{array}$ & 454 \\
\hline
\end{tabular}




\begin{tabular}{|c|c|c|c|c|c|c|c|c|}
\hline $\begin{array}{l}\text { Industry } \\
\text { Subsector }\end{array}$ & Target Industry & $\begin{array}{l}\text { Production } \\
\text { (tonnes/day) }\end{array}$ & $\begin{array}{l}\text { Electricity } \\
\text { (MW) }\end{array}$ & $\begin{array}{l}\text { Heat Usage } \\
\text { in TJ/day } \\
\text { (MMBtu/day) }\end{array}$ & $\begin{array}{c}\text { Emissions } \\
\text { (tonnes } \\
\left.\mathrm{CO}_{2} \mathrm{e} / \mathrm{day}\right)\end{array}$ & $\begin{array}{c}\text { Process Heat Type/ } \\
\text { Purpose }\end{array}$ & $\begin{array}{l}\text { Chemical } \\
\text { Process }\end{array}$ & $\begin{array}{c}\text { Process Heat } \\
\text { Temperature } \\
\left({ }^{\circ} \mathrm{C}\right)\end{array}$ \\
\hline & $\begin{array}{l}\text { Petrochemical } \\
\text { Manufacturing } \\
\text { (Ethylene) }\end{array}$ & 2,665 & 70.4 & $\begin{array}{c}2.37 \\
(2,250)\end{array}$ & 1,252 & $\begin{array}{l}\text { Indirect heat from } \\
\text { combustion gases / } \\
\text { cracking furnace }\end{array}$ & Continuous & 875 \\
\hline & $\begin{array}{l}\text { Alkalies and } \\
\text { Chlorine } \\
\text { Manufacturing }\end{array}$ & & 227 & $\begin{array}{c}4.27 \\
(4,050)\end{array}$ & 3,236 & $(50 \%-75 \%$ CHP) & & \\
\hline & Chlorine & 1,330 & & $\begin{array}{l}0.0161 \\
(15.3)\end{array}$ & & $\begin{array}{l}\text { Steam/drying \& heating of } \\
\text { brine }\end{array}$ & Continuous & 177 \\
\hline & $\begin{array}{l}\text { Sodium } \\
\text { Hydroxide }\end{array}$ & 1,162 & & $\begin{array}{c}4.24 \\
(4,020)\end{array}$ & & $\begin{array}{l}\text { Steam / } \\
\text { drying }\end{array}$ & Continuous & 177 \\
\hline & $\begin{array}{l}\text { Nitrogenous } \\
\text { Fertilizer } \\
\text { Manufacturing } \\
\text { (Ammonia) }\end{array}$ & 757 & 27.1 & $\begin{array}{c}7.03 \\
(6,660)\end{array}$ & 730 & $\begin{array}{l}\text { Indirect heat from } \\
\text { combustion products / } \\
\text { primary steam reformer }\end{array}$ & Continuous & 850 \\
\hline \multirow[t]{5}{*}{$\begin{array}{l}\text { Food } \\
\text { Manufacturing }\end{array}$} & Wet Corn Milling & & 13.1 & $\begin{array}{c}8.06 \\
(7,640)\end{array}$ & 2,053 & & & \\
\hline & Starch & 1,461 & & & & \multirow{2}{*}{$\begin{array}{l}\text { Steam / } \\
\text { steeping }\end{array}$} & \multirow[t]{2}{*}{ Batch } & \multirow[t]{2}{*}{50} \\
\hline & $\begin{array}{l}\text { Corn Gluten } \\
\text { Feed }\end{array}$ & 593 & & & & & & \\
\hline & $\begin{array}{l}\text { Corn Gluten } \\
\text { Meal }\end{array}$ & 137 & & & & \multirow[t]{2}{*}{$\begin{array}{l}\text { Steam / } \\
\text { drying }\end{array}$} & \multirow[t]{2}{*}{ Continuous } & \multirow[t]{2}{*}{177} \\
\hline & Corn Oil & 92 & & & & & & \\
\hline \multirow{3}{*}{$\begin{array}{l}\text { Nonmetallic } \\
\text { Mineral } \\
\text { Product } \\
\text { Manufacturing }\end{array}$} & Lime \& Cement & & & & & & & \\
\hline & Lime & 507 & 1.28 & $\begin{array}{c}3.05 \\
(2,890)\end{array}$ & 559 & $\begin{array}{l}\text { Combustion gases / } \\
\text { heating kiln }\end{array}$ & Continuous & 1,500 \\
\hline & Cement & 2,000 & 13.8 & $\begin{array}{c}9.4 \\
(8,900)\end{array}$ & 3,800 & $\begin{array}{l}\text { Combustion gases } \\
\text { / heating kiln }\end{array}$ & Continuous & 1,200 \\
\hline $\begin{array}{l}\text { Mining } \\
\text { (Except Oil } \\
\text { and Gas) }\end{array}$ & $\begin{array}{l}\text { Potash, Soda, } \\
\text { and Borate } \\
\text { Mining }\end{array}$ & 5,273 & 9.62 & $\begin{array}{c}26.0 \\
(25,00)\end{array}$ & 1,493 & $\begin{array}{c}\text { Steam / } \\
\text { calciner, crystallizer, \& } \\
\text { dryer }\end{array}$ & Continuous & 300 \\
\hline
\end{tabular}




\subsection{Petroleum and Coal Products Manufacturing - Petroleum Refineries}

The petroleum refining industry is the second-largest consumer of energy (Appendix C). Over the past decade, roughly $7 \%$ of the total U.S. energy demand was from oil refineries. As of January 2016 , there were 111 operating refineries, with a capacity of 15.3 million barrels per stream day (bpd) crude distillation (EIA 2016). The average plant size was 138,000 bpd, ranging in size from 3,400 bpd to 584,000 bpd (Figure 16).

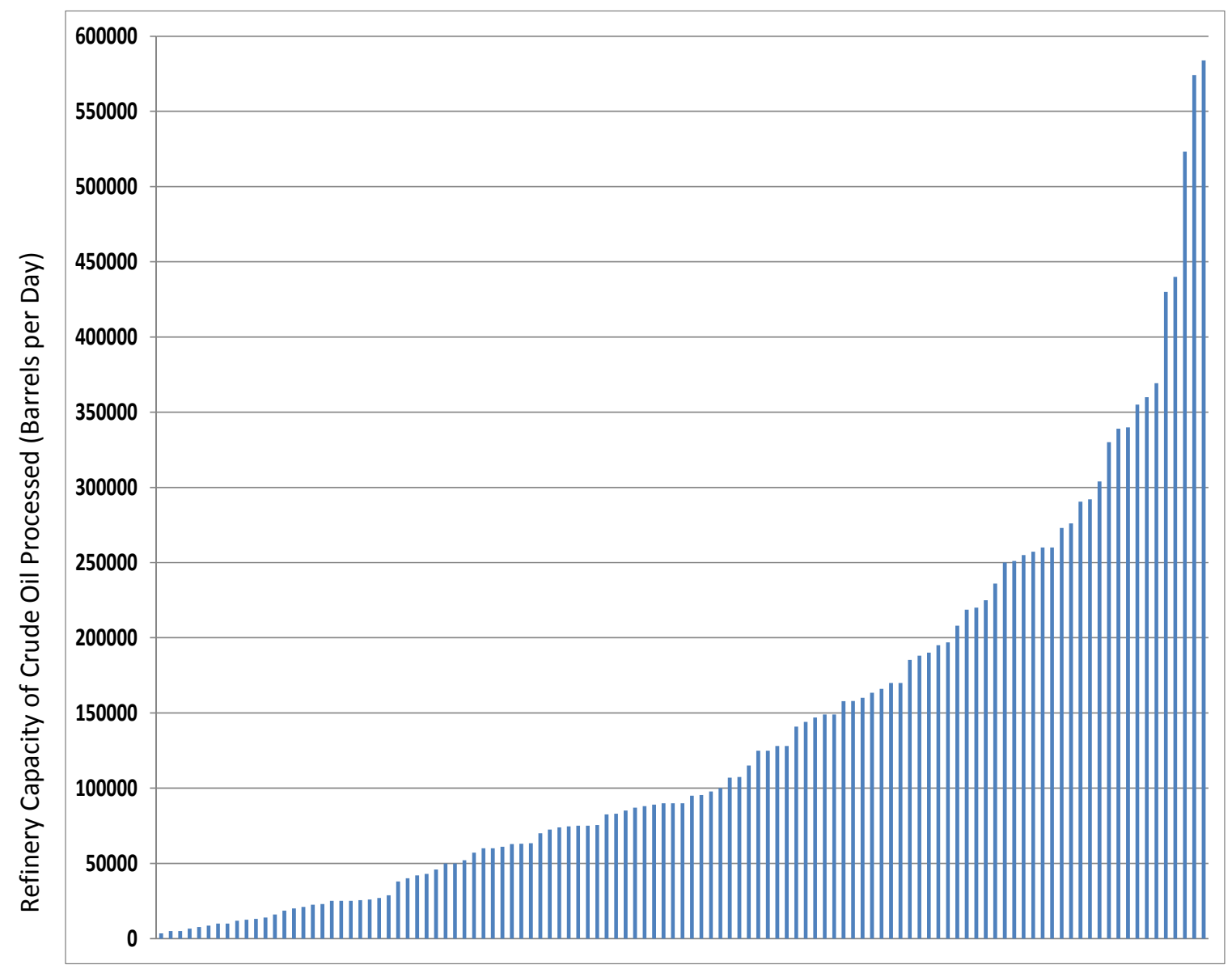

Size Distribution of U.S. Oil Refinery Plants in January 2016

Figure 16. U.S. refinery operating capacity in barrels per stream day, as of January 2016 Data source: EIA (2016)

Older refineries can consume up to $15 \%-20 \%$ of the energy value of their feedstock for supplying process heat, although modern refineries average closer to $6 \%$ and use almost entirely natural gas feedstock or refinery fuel gas to produce the required heat (Ingersoll et al. 2014). Energy in the form of steam, electricity, or direct-fired heat is used in each of the refineries, where the total energy requirement for the average plant 138,000 bpd using about $900 \mathrm{GJ}$ ( 853 MMBtu) net thermal energy. The demand can range up to 3.6 TJ (3,400 MMBtu) net thermal energy for the largest plant. 
In addition to the thermal loads, the average refinery consumes about 100 tonnes of hydrogen each day. About one-half of this hydrogen is produced internally with tail gases. The other half is provided by an external supply (Slone \& Gerdes, 2008; EPA, 2012).

An SMR that can conveniently produce the steam and energy required by a petroleum refinery. The crude can be preheated prior to its input into the crude fractionator. Nearly all of the natural gas (about 300 tonnes per day for the average plant of $138,000 \mathrm{bpd}$ ) that is used to generate steam in a package-tube boiler can be eliminated with an external heat source - particularly when hot gases from a high-temperature SMR are provided to produce high-pressure steam at $600^{\circ} \mathrm{C}$. A recent study revealed that one NuScale Power Module, a pressurized-water reactor (PWR) rated at 160-MW net thermal energy can optimally provide the heat and electricity needed to produce $1,310 \mathrm{~kg} / \mathrm{h}$ hydrogen and $10,400 \mathrm{~kg} / \mathrm{h}$ oxygen using one matched-scale, hightemperature water electrolysis module (Ingersoll et al. 2014). Based on this study, about $387 \mathrm{MWt}$ energy (net) from this type of SMR technology could be used to produce the about 75 tonnes of hydrogen that is currently supplied by merchant sources. For the largest petroleum refineries, the duty rises to 3-4 times this amount, approaching 1,500 MW net thermal demand for hydrogen production.

Most unit operations in a petroleum refinery are set up to operate continuously; however, some units can be started up and run independently if tank storage is sufficient to provide hold-up for intermediate products. Most refineries are set up to process specific grades of crude. Product lines are separated into several streams and each stream is formulated on the basis of seasonal fuel specifications that are met by combining stream fractions that can vary.

Heat supply to refineries is usually approximately constant. However, because a large portion of heat is produced with natural gas from an outside supplier, natural-gas-fired steam boilers or fired-heaters could be modulated with variable supply of clean heat.

In summary, a large reduction in emissions could be achieved if the refinery industry uses cleansource thermal/electrical energy. Economies of scale is likely to limit the proposition to refineries with a net crude stream rate of 50,000 bpd, which could use about $130 \mathrm{MW}$ net thermal output for co-generation of steam, electricity, and hydrogen (see Appendix C) .

\subsection{Primary Metal Manufacturing - Iron and Steel Mills}

The U.S. iron and steel industry is a shadow of its capacity prior to 1980. At its peak raw steel production in 1974, the United States accounted for $20 \%$ of global production, but accounted for only 5\% in 2013 (USGS 2015). However, U.S. steel production still accounts for at least 5\% of the total energy use by industry and about $3 \%$ of the industrial-sector $\mathrm{CO}_{2}$ emissions (Table 2). The emissions come primarily from traditional blast furnace and either a basic oxygen furnace or open hearth that use coke and natural gas, respectively, to recover and purify the iron from iron ore. In the blast furnace, combustion of partial oxidation (i.e., gasification) of the metallurgicalgrade coke slowly brings the smelt up to $1,700^{\circ} \mathrm{C}$. Carbon monoxide (CO) reduces the iron oxide to molten elemental iron. The molten metal is refined and purified in the basic oxygen furnace at around $1,600-1,650^{\circ} \mathrm{C}$ to produce castable or ductile iron metal (Elshennawy \& Weheba, 2015; EPA, 2012; Eggeman, Steel, 2010). Metals annealing and rolling requires additional heat, which is typically supplied by in-situ natural gas burning. 
Scrap-metal recycling plants now produce about one-half of all U.S. steel in electric-arc furnaces. The quality of this steel is inferior to steel that is produced from raw ore because the contaminant and metals mixtures that come to the plant at any given time.

A technical review of the steel manufacturing process steps reveals few, if any, opportunities for direct substitute clean heat sources to iron and steel making process unit operations (Appendix D). The up-front unit operation heat loads for the steel industry are very difficult to replace because combustion gases also participate in chemical redox reactions or radiant heat transfer. Hydrogen is an alternative reducing agent for iron ore. Reduction takes place faster (10x) than $\mathrm{CO}$ at temperatures above $800^{\circ} \mathrm{C}$, but heat has to be supplied because the reaction is endothermic.

$$
\begin{array}{lc}
2 \mathrm{Fe}_{2} \mathrm{O}_{3}+3 \mathrm{C} \rightarrow 4 \mathrm{Fe}+3 \mathrm{CO}_{2} & \text { Blast Furnace Coke Reaction } \\
2 \mathrm{Fe}_{2} \mathrm{O}_{3}+6 \mathrm{CO} \rightarrow 4 \mathrm{Fe}+6 \mathrm{CO}_{2} & \text { Direct Reduction by CO } \\
2 \mathrm{Fe}_{2} \mathrm{O}_{3}+6 \mathrm{H}_{2} \rightarrow 4 \mathrm{Fe}+6 \mathrm{H}_{2} \mathrm{O} & \text { Direct Reduction by } \mathrm{H}_{2}
\end{array}
$$

Some advances have been made on the subject of direct reduction of iron with hydrogen, ${ }^{\mathrm{u}}$ and it has been estimated that hydrogen-based steel making could reduce total $\mathrm{CO}_{2}$ emissions from steel production by $80 \%$ (Fischedick et al. 2014b). However, there are currently no commercial plants that exclusively use hydrogen to produce iron and steel.

The front end of steel mills generally operates in a batch manner, with charges of iron ore, coke, and limestone being charged at once to the blast furnace. The electric-arc furnace can be operated in a batch or semi-batch mode. The back end of the steel-making process is generally operated in a continuous mode. Provisions for intermittent clean heat can be established in case an external clean energy source is available on an intermittent basis.

\subsection{Paper Manufacturing - Paper, Paperboard, and Pulp Mills}

Although paper, paperboard, and pulp mills represent the third-largest consumer of energy in the United States, more than two-thirds $(\sim 70 \%)$ of the raw energy used is steam duties that are principally used for concentrating and drying materials. The "hog fuel" composed of bark, limbs, and sawdust is burned to produce superheated steam for electricity generation and process heating in pulp production. Pulp mills also burn black liquor (a mixture of oily lignin and sodium hydroxide caustic) in a boiler to recover the sodium for recycling (see Appendix E and Appendix F). Consequently, the pulp and paper industry in aggregate could be considered net-zero carbon in many cases, using CHP to produce the steam and electrical loads of the plant. Stand-alone pulp mills produce excess power, whereas stand-alone paper and paperboard mills use roughly $21 \mathrm{TJ}$ (20,000 MMBtu) energy and 54 MW electricity.

\footnotetext{
u As an example, the ENERGIRON process converts iron ore pellets or lumps into metallic iron with a countercurrent flow of very hot $\left(950-1,100^{\circ} \mathrm{C}\right)$ reducing gases that include hydrogen at high pressure $(6-8$ bar).
} 
Until alternative markets are developed for black liquor, the pulp industry is unlikely to benefit from additional clean energy sources. Paper and paperboard mills, on the other hand, use a variety of heat levels to concentrate and dry pulp once it has been solubilized and sprayed onto drum rollers for drying. The drying process is operated on a semi-batch basis where specific products are produced on a "campaign basis." Variable supply of clean heat, on the order of 5-10 $\mathrm{MW}_{\mathrm{t}}$, can be mixed with the steam supply or combustion gas effluent that are used to concentrate the pulp and to dry the paper, respectively. With the addition of the externally produced steam or hot gas (i.e., heated air), plant steam generation and gas-fired burners can be rapidly modulated in correspondence with the external heat source.

\subsection{Chemical Manufacturing}

Within the chemicals industry, this report highlights four processes that represent the vast number and variety of organic chemical, inorganic minerals, ammonia, and synthetic polymer industries. The intent, of course, is to understand the opportunity to replace $\mathrm{CO}_{2}$ emissionsproducing sources with zero-emissions heat and electricity.

\subsubsection{All Other Basic Organic Chemical Manufacturing (Methanol)}

We chose methanol production as a surrogate for the All Other Basic Organic Chemicals Industry because it involves a common step of steam reformation that requires heat. Steam reformation is followed by a tubular synthesis reactor that produces methanol while removing heat generated by the reactions. The unconverted reactants are separated from the products using a condenser for recycle back to the reactor. Gentle evaporation then purifies the product (see Appendix G).

Methanol is one of the predominant commodity chemicals in the United States and around the world. It is a feedstock to produce chemicals, such as acetic acid and formaldehyde, which in turn are used in products such as adhesives, foams, plywood subfloors, solvents, and windshield washer fluid. In recent years, the use of methanol in the production of olefins, or methanol-toolefins, has grown rapidly (Alvarado 2016). Methanol can also be used on its own as a vehicle fuel or blended directly into gasoline to produce a high-octane, efficient fuel with lower emissions than conventional gasoline. Methanol is a key reactant for making biodiesel, and it can be dehydrated to produce dimethyl ether - also a clean-burning fuel with properties similar to propane. There has been constant interest in converting synthetic gasoline derived from natural gas and coal into motor gasoline using a process pioneered by ExxonMobil referred to as methanol-to-gasoline. However, the low price of petroleum fuels may impede commercialization of this process, except in China, where a commercial demonstration is in operation (Khalil 2015).

There are at least two opportunities to replace natural gas combustion in methanol production: one is the heat needed for the primary reformer, and the second is the heat required for methanol purification. The former case is illustrated in Figure 17. It is feasible to replace the hot combustion gases with a flameless hot gas produced by an external source that is hotter than $740^{\circ} \mathrm{C}$ to effectively heat the primary reformer and to preheat the natural gas feed. About 12.9 $\mathrm{TJ} /$ day (12,300 MMBtu/day) of energy is required for the average-size methanol plant. 


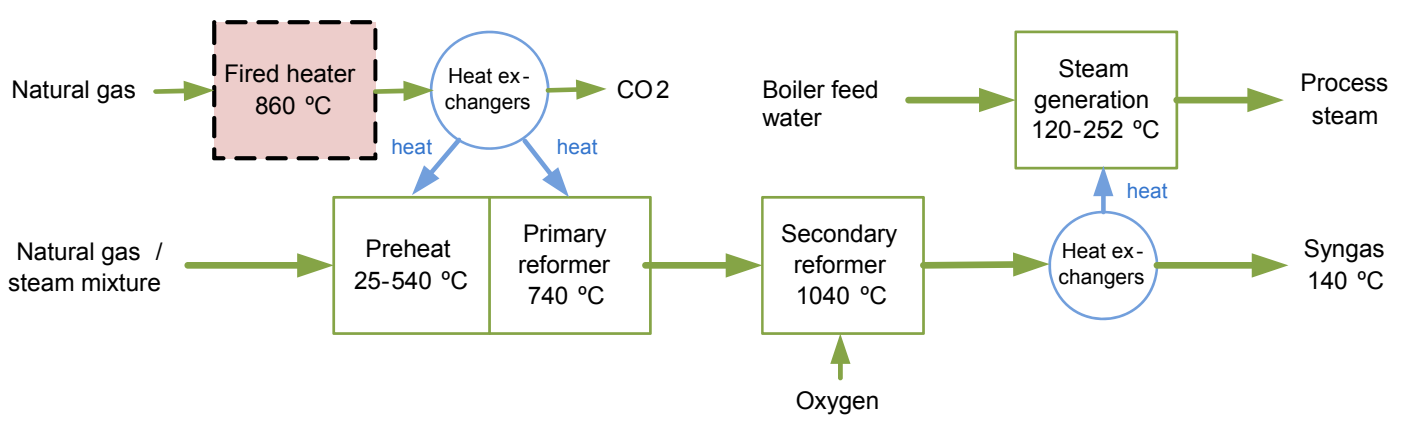

Figure 17. Energy use in synthetic gasoline production for use in methanol synthesis

High-temperature nuclear reactors (either molten salt or high-temperature gas-cooled reactors) and solar industrial process heat (SIPH) plants are capable of supplying this level of heat directly. Opportunities to use lower-temperature heat sources are discussed in the following section, but have limited impact on $\mathrm{CO}_{2}$ reduction unless the methanol production plant is redesigned to implement a new heat-integration scheme.

Methanol can also be produced by hydrogenation of $\mathrm{CO}_{2}$. Although this reaction is less efficient than the conventional process, it does provide a route for $\mathrm{CO}_{2}$ capture and use with hydrogen produced by clean energy sources. The economic feasibility of this process route depends on the cost of natural gas, production cost of clean energy, and clean-energy production credits in the future.

The steam reforming process at the front end of a methanol plant is designed to operate continuously to avoid thermal cycling of catalysts. Methanol plants take 1-2 days to start up and 2-3 days to shut down to avoid thermal shock. However, an intermittent hot-gas source could be blended with the combustion effluent of a natural gas burner to reduce $\mathrm{CO}_{2}$ emissions proportional to the mass flow of the external heat source. In this case, hot helium circulation is unlikely to be practical; rather, a recycle loop of the natural gas burner exhaust could be used to transfer heat from the external heat source.

A variable external supply of heat (3-5 megawatt-electric [MWe]) can be used for methanol purification in the down-stream unit operations of the plant.

\subsubsection{Ethyl Alcohol Manufacturing}

The United States produced about 50 billion liters of ethanol for consumption and about 56 billion liters of gasoline additive in 2016, according to resources listed in Appendix H. The typical plant is based on enzymatic hydrolysis and fermentation of hydrolysate produced from biomass. Byproduct lignin, unconverted cellulose, biomass sludge, and biogas from a wastewater anaerobic digester are burned to produce the steam and power that is required by the plant processes. External combustion fuel is mainly used to help burn the biomass residue combustibles. Overall, enough steam is produced to generate excess power, which is usually sold to the grid. Consequently, there would be no purpose to offset the combustion fuel with hot gases, unless an alternative use of the byproducts is implemented. Because the emissions are a derivative of the combustion of biomass, the process may be considered to be low-emissions in the long-term as long new biomass is grown to replace the combusted biomass. Emissions from growing and harvesting biomass crops with fossil-based energy, production and application of 
chemicals (fertilizer and pesticides), and changes in land cover or management will still occur and increase atmospheric carbon dioxide concentrations (Bracmort 2016).

\subsubsection{Petrochemical Manufacturing (Ethylene)}

Ethylene production in the United States nearly matches the production rates and energy demand of methanol. About $60 \%$ of annual ethylene production is used to produce polyethylene (Figure 18), a popular thermoplastic commodity used in consumer products (especially products created by rotational molding) (D\&M Plastics Inc. 2016). The remaining 40\% of annual ethylene production is used to produce ethylene glycol, vinyl chloride, styrene, and detergent alcohols, among other chemicals.

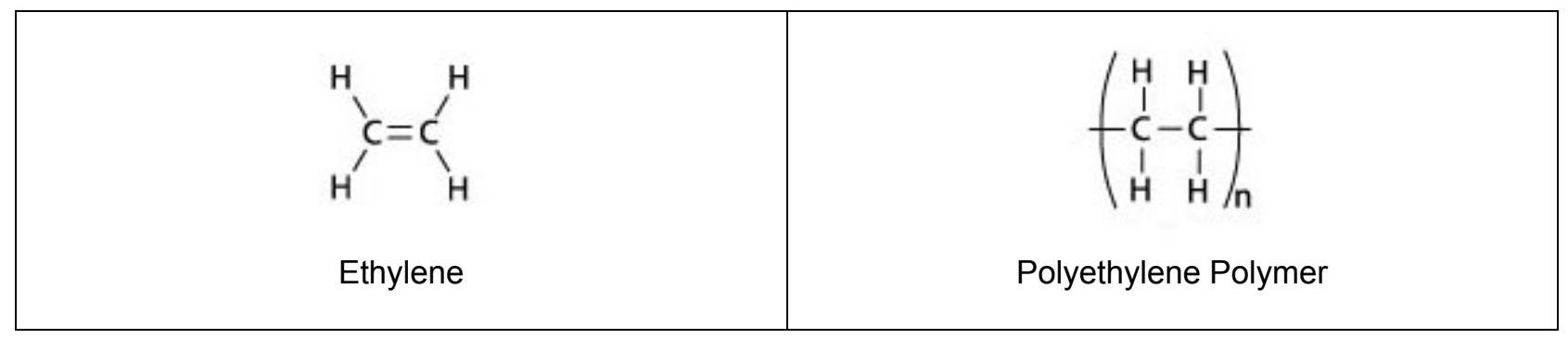

Figure 18. Molecular diagram for ethylene and polyethylene polymer

The most common process for producing ethylene is to scission naphtha or other petroleum gases in a cracking furnace that operates at temperatures ranging from $750^{\circ} \mathrm{C}$ to $875^{\circ} \mathrm{C}$. Appendix I reveals that the main, if not only, opportunity to use a clean heat source is within this furnace. However, because the heat duty of about $50 \mathrm{TJ} /$ day (47,000 MMBtu/day) is mainly achieved by combustion of pyrolysis oil byproduct, a typical plant only requires about $2.4 \mathrm{TJ} /$ day $(2,250$ $\mathrm{MMBtu}$ /day) of additional fuel. An SMR is probably an impractical candidate for a stand-alone plant, unless steam and electricity (about $65 \mathrm{MWe}$ ) demands are met by an SMR that sends all other power generation to the grid. A concentrating solar unit that is capable of providing hot gases at about $900-1,000^{\circ} \mathrm{C}$ may be a reasonable match, or a thermal energy storage battery that can generate a hot gas at temperatures comparable to combustion effluent.

Ethylene plants are best operated at a constant rate. However, an intermittent clean-energy steam supply can reduce the steam duties currently met with a natural-gas boiler. A steam accumulator could increase use percentage of the clean energy source.

\subsubsection{Alkalies and Chlorine Manufacturing}

The chlor-alkali industry represents a wide class of electrochemical processes in the United States that consume a large fraction of the electricity used by the process industry. Thermal energy is mainly required for evaporation and concentration of the two products made from decomposing salt $(\mathrm{NaCl})$ : sodium hydroxide and chlorine gas (Appendix J). Therefore, nearly all of the thermal energy required - about 4.27 TJ/day (4,050 MMBtu/day) - is used to produce steam. This amount could be readily tapped from an SMR that primarily produces electricity for the plant duty of about $227 \mathrm{MWe}$ for the plant electrolyzer and other loads. A concentrating solar unit that is used to generate low-pressure steam is likely to be sufficient to eliminate combustionfired steam generation at the plant. Thermal energy storage reservoirs that are designed to 
continuously generate steam on demand are also a candidate for a zero carbon-emissions, thermal energy source.

The electrolysis (diaphragm cell) of chlor-alkali plants is best operated at a constant rate to maintain stream concentrations in the electrolysis cell. However, all down-stream concentrating and drying unit operations can be operated in an intermittent pattern, provided that holding tanks have sufficient capacity and that the solutions are held at temperatures sufficient to avoid crystallization in the holding tanks and/or reactors. A steam accumulator could increase the use percentage of a clean energy source by helping maintain continuous flow/operations of all unit operations.

\subsubsection{Nitrogenous Fertilizer Manufacturing (Ammonia and Derivatives)}

During 2015, 30 plants produced 9.4 million tonnes of ammonia $\left(\mathrm{NH}_{3}\right)$ (Appendix $\left.\mathrm{K}\right)$, principally based on the Haber-Bosch reaction processes. The principal feedstock to these plants is natural gas, which is reformed with steam to produce a target stoichiometric gas mixture of $\mathrm{CO}_{2}, \mathrm{~N}_{2}$, and $\mathrm{H}_{2}$. Sorbents are used to remove $\mathrm{CO}_{2}$ and other contaminants prior to synthesizing $\mathrm{NH}_{3}$. Ammonia is used to produce a wide variety of fertilizers, nitric acid, and amine-based chemicals.

Clean heat at temperatures of at least about $800^{\circ} \mathrm{C}$ can be used to reduce the combustion of natural gas in the first stage of a conventional steam-methane reforming-based ammonia plant (Wood, 2010). Alternatively, hydrogen can be produced with low-temperature proton-exchange membrane (PEM) electrolysis or high-temperature steam electrolysis, with nitrogen optimally obtained by cryogenic air-separation units and refrigeration units powered by electricity. In this case, the clean energy source is mainly electricity. Technical and economic assessments of ammonia or ammonia derivatives production with high-temperature SMRs were recently completed by the Next Generation Nuclear Plant Industry Alliance (Wood, 2010). The assessments conclude that the ammonia industry is suitable for re-invention with transformative hydrogen-generation technologies. Incentives to reduce $\mathrm{CO}_{2}$ emissions could stimulate this change in the very near future.

The steam-reforming process at the front end of a conventional ammonia plant is designed to operate continuously to avoid thermal cycling of catalysts. Each of the 30 plants consumes about $7.03 \mathrm{TJ} /$ day (6,600 MMBtu/day). A constant external heat source is needed to effectively displace the heating in the primary reformer. However, an intermittent hot-gas source could be blended with the combustion effluent of a natural gas burner to reduce $\mathrm{CO}_{2}$ emissions proportional to the mass flow of the external heat source. In this case, hot helium circulation would not be practical; rather, a recycle loop of the natural gas burner exhaust could be used to transfer heat from the external heat source.

\subsection{Food Manufacturing - Wet Corn Milling}

The wet corn and milling industry as a whole consumes more energy than any other class of food manufacturing. The detailed plant discussion in Appendix L reveals that an average plant (processing 100,000 bushels per day) consumes about $8 \mathrm{TJ} /$ day of heat for steeping corn grain and processing in order to obtain corn oil, fiber and starch products and 13.1 MWe of electricity is consumed for grinding and milling operation, respectively. 
A small solar boiler fed from a SIPH solar field could readily replace fossil-fired boilers in many food processes industries. Energy storage could provide constant steam supply, unless a back-up fossil-fired boiler is on standby. Seasonal operation and demand profiles for some food processing are additional considerations to take into account depending on the type of food that is processed. For example, tomatoes and other vegetables that can spoil in a matter of days or weeks must be processed during the season they are produced. Potatoes, on the other hand, as well as grains, can be stored and processed on a near steady rate.

A steam accumulator can be used to provide steam duties as they are needed for the various unit operations. Some of the unit operations can also be operated in batch-mode provided that holder tanks are added to the process sequences.

\subsection{Nonmetallic Mineral Product Manufacturing - Lime and Cement Manufacturing}

Lime and cement production is one of the major industry $\mathrm{CO}_{2}$ emitters because of the energy intensity and high heating levels required to reduce limestone, silicates, and clays into calcium oxide and pozzolan admixtures, which are used to produce bricks, mortar, and Portland cement. Over-fire combustion with direct contact of the mineral solids is needed to achieve the thermal heat rates and peak temperatures of $1,200^{\circ} \mathrm{C}$ and $1,500^{\circ} \mathrm{C}$ necessary for lime and cement production, respectively (see Appendix M). Only an electric arc or plasma torch can achieve these same thermal levels, but they may not be able to effect the same chemistry and also avoid melting and vitrification of the mineral feeds.

Hydrogen enrichment of the natural-gas-fired burners and the use of biomass char and/or biogas may be the best method of reducing the life-cycle emissions of lime and cement production. Even $\mathrm{CO}_{2}$ capture is a difficult proposition for these processes because of the mass and relatively dilute concentration of the flue gas. However, oxy-firing could improve the technical feasibility of carbon capture for kiln operations.

\subsection{Mining (Except Oil and Gas) - Soda Ash, Potash, and Borate Mineral Mining}

Although the soda ash, potash, and borate mineral mining industry has few plants (11 total reporting to the EPA GHGRP), an individual plant consumes on average $150 \mathrm{MWt}$ of heat and a total of $299 \mathrm{MWt}$ CHP. In the case of soda ash, four plants are located in close proximity in southwest Wyoming, where trona mineral is abundant.

Trona is a naturally occurring mineral sodium sesquicarbonate $\left[\mathrm{Na}_{2} \mathrm{CO}_{3} \cdot \mathrm{NaHCO}_{3} \cdot 2 \mathrm{H}_{2} \mathrm{O}\right]$. Trona processing to make soda ash (or sodium carbonate, $\mathrm{Na}_{2} \mathrm{CO}_{3}$ ) entails converting the sodium bicarbonate $\left(\mathrm{NaHCO}_{3}\right)$ into carbonate, then removing the clay and iron contaminants by recrystallizing the sodium carbonate. After mining and crushing, the trona ore is calcined at about $250^{\circ} \mathrm{C}$ to drive off the water that hydrates the sesquicarbonate crystal and to drive the reaction:

$$
2 \mathrm{NaHCO}_{3} \rightarrow \mathrm{Na}_{2} \mathrm{CO}_{3}+\mathrm{H}_{2} \mathrm{O}+\mathrm{CO}_{2}
$$


The sodium carbonate is dissolved in water, leaving behind insoluble clays and iron compounds to be physically separated from the sodium carbonate solution. Residual organic contaminants in the trona are adsorbed onto activated carbon to improve crystal formation as water evaporates to concentrate the solution, causing crystals to form. A facility producing 2,740 tonnes/day of soda ash - the scale of each one of the four plants near Green River, Wyoming - uses an estimated total of $13.5 \mathrm{TJ} /$ day $(12,800 \mathrm{TBtu} /$ day $)$ and $5 \mathrm{MWe}$ for a total CHP thermal energy load of about $161 \mathrm{MW}_{\mathrm{t}}$ of heat (see Appendix N). Four plants combined require about $625 \mathrm{MW}_{\mathrm{t}}$. This represents a unique case where a cluster of plants already exists.

The total demand, heat quality (mostly steam), and proximity of the four plants in Wyoming provide an excellent opportunity to replace fossil-fired steam boilers with a nuclear-based heat source. Other stand-alone plants of this variety may be candidates if economies of scale are favorable; that is, when the cost of building and operating an SMR or a SIPH facility is comparable to the costs of fossil-fuel package-tube boilers. In either case, assessment of specifics such as solar radiation and availability of the land needed for a SMR would improve understanding.

Minerals processing is carried out in a semi-batch mode. Steam supply from an external source could use a steam accumulator to accommodate intermittent generation of heat. Any amount of steam supplied from the external heat source could proportionally reduce steam that is generated by a fossil-fuel-fired steam boiler. 


\section{ALTERNATIVE HEAT SUPPLIES AND HEAT TRANSPORT}

Replacement of in-plant heat generation with a flameless heat source provided by a nuclear reactor or SIPH system begins with:

1. Assessing the size and dependability of the external heat source

2. Assessing the heat-transport distance and distribution of the thermal working fluid (and return in a closed system)

3. Selecting an appropriate heat-transfer medium

4. Evaluating existing or new heat exchangers and heat transfer into reaction processes

5. Preventing fugitive radiological contamination.

The previous section shows that individual oil refineries, iron- and steel-making plants, cement/lime plants, and some large chemical plants (e.g., methanol, ammonia, and soda ash) have comparably large heat duties and electricity demands, which potentially could be met with a SMR (10 to $300 \mathrm{MWe}$ ) (Todreas 2015). Many processes require low-quality steam under the critical point, up to temperatures of $350^{\circ} \mathrm{C}$ and at moderate pressure up to about 2 megapascals $(\mathrm{MPa})$. Steam temperatures up to $600^{\circ} \mathrm{C}$ are used for petroleum refining. Higher-temperature steam up to $600-650^{\circ} \mathrm{C}$ and $15-20 \mathrm{MPa}$ is most often used as a flow motive in steam turbines that generate electrical power. Stainless-steel piping is required at these pressures and temperatures. Even higher-temperature/high-pressure steam, often referred to as ultrasupercritical steam (up to about $760^{\circ} \mathrm{C}$ and $35 \mathrm{MPa}$ ), could be produced by advanced power systems. Nickel-metal alloys are necessary for steam generation and transport under these conditions. A review of power generation options for electricity is a useful guide for matching thermal duties that could theoretically be supplied by harvesting the steam normally supplied to the power generators (ORNL 2012).

Steam-methane reforming, the basic unit operation to produce methanol, or in combination with the water-gas-shift reaction to produce hydrogen, requires heat (as hot combustion gas) exceeding $750^{\circ} \mathrm{C}$ (for methanol syngas feed) and $800^{\circ} \mathrm{C}$ for hydrogen. This may be supplied by a high-temperature salt or a high-temperature helium gas, which can only be attained with a hightemperature nuclear reactor or SIPH.

High-temperature helium systems operating at temperatures up to $750^{\circ} \mathrm{C}$ have been qualified by the Nuclear Regulatory Commission for nuclear plants. Operations above this temperature require American Society of Mechanical Engineers code qualification. The Next Generation Nuclear Plant (NGNP) Program has made progress in alloys for helium systems to operate at temperatures approaching $950^{\circ} \mathrm{C}$ (Next Generation Nuclear Plant Project 2011). If this work is completed, direct heat delivery for the chemical industry may be valuable.

In the case of very high-temperature unit operations such as lime and cement making, it is possible to burn biomass or hydrogen that is generated by nuclear and renewable energy processes to attain the temperature necessary to calcine or smelt minerals and ores. 
Electrical heating can be used to replace combustion systems. But in most cases, this will require new chemical-process reactor designs, whereas steam and hot-gas substitution can more readily replace the chemical-process reactor heater.

In the case of smaller plants, economies of scale may require a cooperating cluster of plants - an energy park (EP) — to take advantage of a single, large, heat supplier.

Finally, most of the pulp and paper mills and ethyl alcohol plants may be considered net-zero carbon according to the view that they mainly combust biomass or biomass residues. However, the concept of an EP may also be relevant for GHG mitigation in other sectors if the biomass residues can be converted into a chemical feedstock or fuels for processes that require high temperatures. For example, gasification of the biomass residues can provide synthetic gasoline for chemical synthesis, or the residues may be burned as fuel for cement and steel making. Therefore, use of multi-energy (ME) sources can also be considered when replacing fossil fuels.

\subsection{Heat Matching with Very Low Carbon Heat Generators}

SIPH, advanced nuclear reactors, and geothermal energy can be scaled to provide heat to most of the chemical industrial manufacturing plants in the United States. We estimate in Section 4.1.4 the number of generating units needed to meet the thermal demands of relevant industries. Examples of SIPH demonstration and operating commercial facilities can be adapted to industrial-process heating needs from small to large scales. The choice a SIPH technology will be based on the area for deployment and the heat-transfer media that is used.

Nuclear heat energy will likely favor larger commercial operations simply to take advantage of economies of scale. Nuclear operations will require round-the-clock operators and security. Hence, for purposes of this study, it is assumed that the minimum energy service for a nuclear plant is $150 \mathrm{MW}_{\mathrm{t}}$.

Geothermal energy systems have a high availability factor with inherent storage capability. This attribute makes geothermal energy amenable for several heating applications. However, geothermal energy would be difficult to economically transport from generation sites to an industry user.

\subsubsection{SIPH System Examples}

Currently, there are over $1,800 \mathrm{MW}$ of installed concentrating solar power (CSP) in the United States (SEIA 2016). Installed capacity of parabolic trough collector SIPH is $4.028 \mathrm{MW}_{\mathrm{t}}{ }^{\mathrm{v}} \mathrm{A}$ recent overview of CSP and SIPH around the world shows many systems are relatively small (ranging from $100 \mathrm{~kW}-100 \mathrm{MW}$ ), generating heat in the range of $150-300^{\circ} \mathrm{C}$ (Rawlins \& Ashcroft, 2013). These examples demonstrate the opportunity to apply SIPH to a wide range of industries, including the examples highlighted in this report. The list of CSP system demonstrations in the United States also could be readily applied to industrial heating loadsreplacing or complementing fossil-fuel heat sources to reduce net emissions and the effect of price volatility that accompany fossil sources. Net capacity corresponds to the difference between gross generation and usage within the plant.

\footnotetext{
v SHIP Plants, AEE Intec, "Solar Thermal Plants Database.”
} 
Table 9. CSP Projects for Electricity Generation in the United States (NREL 2016a)

\begin{tabular}{|c|c|c|c|c|}
\hline Project Name & Location & Owner & $\begin{array}{l}\text { Turbine Capacity } \\
\text { (MW) }\end{array}$ & Status \\
\hline $\begin{array}{l}\text { Maricopa Solar } \\
\text { Project }\end{array}$ & Peoria, Arizona & Tessera Solar & $\begin{array}{l}\text { Net: } 1.5 \\
\text { Gross: } 1.5\end{array}$ & $\begin{array}{l}\text { Non- } \\
\text { Operational }\end{array}$ \\
\hline Saguaro Power Plant & $\begin{array}{l}\text { Red Rock, } \\
\text { Arizona }\end{array}$ & $\begin{array}{l}\text { Arizona Public } \\
\text { Service }\end{array}$ & $\begin{array}{l}\text { Net: } 1.0 \\
\text { Gross: } 1.16\end{array}$ & Operational \\
\hline $\begin{array}{l}\text { Solana Generating } \\
\text { Station (Solana) }\end{array}$ & $\begin{array}{l}\text { Phoenix, } \\
\text { Arizona }\end{array}$ & $\begin{array}{l}\text { Abengoa Solar } \\
\text { Liberty Interactive } \\
\text { Corporation }\end{array}$ & $\begin{array}{l}\text { Net: } 250.0 \\
\text { Gross: } 280.0\end{array}$ & Operational \\
\hline $\begin{array}{l}\text { Genesis Solar Energy } \\
\text { Project }\end{array}$ & $\begin{array}{l}\text { Blythe, } \\
\text { California }\end{array}$ & Genesis Solar, LLC & $\begin{array}{l}\text { Net: } 250.0 \\
\text { Gross: } 250.0\end{array}$ & Operational \\
\hline $\begin{array}{l}\text { Ivanpah Solar Electric } \\
\text { Generating System } \\
\text { (ISEGS) }\end{array}$ & $\begin{array}{l}\text { Primm, } \\
\text { California }\end{array}$ & $\begin{array}{l}\text { NRG Energy; } \\
\text { BrightSource } \\
\text { Energy; Google }\end{array}$ & $\begin{array}{l}\text { Net: } 377.0 ; \\
\text { Gross: } 392.0\end{array}$ & Operational \\
\hline $\begin{array}{l}\text { Kimberlina Solar } \\
\text { Thermal Power Plant } \\
\text { (Kimberlina) }\end{array}$ & $\begin{array}{l}\text { Bakersfield, } \\
\text { California }\end{array}$ & Ausra & $\begin{array}{l}\text { Net: } 5.0 ; \\
\text { Gross: } 5.0\end{array}$ & Operational \\
\hline Mojave Solar Project & $\begin{array}{l}\text { Harper Dry } \\
\text { Lake, California }\end{array}$ & Mojave Solar, LLC & $\begin{array}{l}\text { Net: } 250.0 ; \\
\text { Gross: } 280.0\end{array}$ & Operational \\
\hline $\begin{array}{l}\text { Sierra SunTower } \\
\text { (Sierra) }\end{array}$ & $\begin{array}{l}\text { Lancaster, } \\
\text { California }\end{array}$ & eSolar & $\begin{array}{l}\text { Net: } 5.0 ; \\
\text { Gross: } 5.0\end{array}$ & Operational \\
\hline $\begin{array}{l}\text { Solar Electric } \\
\text { Generating Station I } \\
\text { (SEGS I) }\end{array}$ & $\begin{array}{l}\text { Daggett, } \\
\text { California } \\
\text { (Mojave } \\
\text { Desert) }\end{array}$ & Cogentrix & $\begin{array}{l}\text { Net: } 13.8 ; \\
\text { Gross: } 13.8\end{array}$ & Operational \\
\hline $\begin{array}{l}\text { Solar Electric } \\
\text { Generating Station II } \\
\text { (SEGS II) }\end{array}$ & $\begin{array}{l}\text { Daggett, } \\
\text { California } \\
\text { (Mojave } \\
\text { Desert) }\end{array}$ & Cogentrix & $\begin{array}{l}\text { Net: } 30.0 \\
\text { Gross: } 33.0\end{array}$ & Operational \\
\hline $\begin{array}{l}\text { Solar Electric } \\
\text { Generating Station III } \\
\text { (SEGS III) }\end{array}$ & $\begin{array}{l}\text { Kramer } \\
\text { Junction, } \\
\text { California } \\
\text { (Mojave } \\
\text { Desert) }\end{array}$ & NextEra $(50 \%)$ & $\begin{array}{l}\text { Net: } 30.0 \\
\text { Gross: } 33.0\end{array}$ & Operational \\
\hline $\begin{array}{l}\text { Solar Electric } \\
\text { Generating Station IV } \\
\text { (SEGS IV) }\end{array}$ & $\begin{array}{l}\text { Kramer } \\
\text { Junction, } \\
\text { California } \\
\text { (Mojave } \\
\text { Desert) }\end{array}$ & NextEra $(38 \%)$ & $\begin{array}{l}\text { Net: } 30.0 \\
\text { Gross: } 33.0\end{array}$ & Operational \\
\hline
\end{tabular}




\begin{tabular}{|c|c|c|c|c|}
\hline Project Name & Location & Owner & $\begin{array}{l}\text { Turbine Capacity } \\
\text { (MW) }\end{array}$ & Status \\
\hline $\begin{array}{l}\text { Solar Electric } \\
\text { Generating Station V } \\
\text { (SEGS V) }\end{array}$ & $\begin{array}{l}\text { Kramer } \\
\text { Junction, } \\
\text { California } \\
\text { (Mojave } \\
\text { Desert) }\end{array}$ & NextEra $(46 \%)$ & $\begin{array}{l}\text { Net: } 30.0 \\
\text { Gross: } 33.0\end{array}$ & Operational \\
\hline $\begin{array}{l}\text { Solar Electric } \\
\text { Generating Station VI } \\
\text { (SEGS VI) }\end{array}$ & $\begin{array}{l}\text { Kramer } \\
\text { Junction, } \\
\text { California } \\
\text { (Mojave } \\
\text { Desert) }\end{array}$ & NextEra $(41 \%)$ & $\begin{array}{l}\text { Net: } 30.0 \\
\text { Gross: } 35.0\end{array}$ & Operational \\
\hline $\begin{array}{l}\text { Solar Electric } \\
\text { Generating Station VII } \\
\text { (SEGS VII) }\end{array}$ & $\begin{array}{l}\text { Kramer } \\
\text { Junction, } \\
\text { California } \\
\text { (Mojave } \\
\text { Desert) }\end{array}$ & NextEra $(50 \%)$ & $\begin{array}{l}\text { Net: } 30.0 \\
\text { Gross: } 35.0\end{array}$ & Operational \\
\hline $\begin{array}{l}\text { Solar Electric } \\
\text { Generating Station } \\
\text { VIII (SEGS VIII) }\end{array}$ & $\begin{array}{l}\text { Harper Dry } \\
\text { Lake, California } \\
\text { (Mojave } \\
\text { Desert) }\end{array}$ & NextEra $(50 \%)$ & $\begin{array}{l}\text { Net: } 80.0 \\
\text { Gross: } 89.0\end{array}$ & Operational \\
\hline $\begin{array}{l}\text { Solar Electric } \\
\text { Generating Station IX } \\
\text { (SEGS IX) }\end{array}$ & $\begin{array}{l}\text { Harper Dry } \\
\text { Lake, California } \\
\text { (Mojave } \\
\text { Desert) }\end{array}$ & NextEra $(50 \%)$ & $\begin{array}{l}\text { Net: } 80.0 \\
\text { Gross: } 89.0\end{array}$ & Operational \\
\hline $\begin{array}{l}\text { Colorado Integrated } \\
\text { Solar Project (Cameo) }\end{array}$ & $\begin{array}{l}\text { Palisade, } \\
\text { Colorado }\end{array}$ & Xcel Energy & $\begin{array}{l}\text { Net: } 2.0 \\
\text { Gross: } 2.0\end{array}$ & $\begin{array}{l}\text { Non- } \\
\text { Operational }\end{array}$ \\
\hline $\begin{array}{l}\text { Martin Next } \\
\text { Generation Solar } \\
\text { Energy Center } \\
\text { (MNGSEC) }\end{array}$ & $\begin{array}{l}\text { Indiantown, } \\
\text { Florida }\end{array}$ & $\begin{array}{l}\text { Florida Power \& } \\
\text { Light Co. }\end{array}$ & $\begin{array}{l}\text { Net: } 75.0 \\
\text { Gross: } 75.0\end{array}$ & Operational \\
\hline $\begin{array}{l}\text { Holaniku at Keahole } \\
\text { Point }\end{array}$ & $\begin{array}{l}\text { Keahole Point, } \\
\text { Hawaii }\end{array}$ & $\begin{array}{l}\text { Keahole Solar } \\
\text { Power, LLC }\end{array}$ & $\begin{array}{l}\text { Net: } 2.0 \\
\text { Gross: } 2.0\end{array}$ & Operational \\
\hline $\begin{array}{l}\text { Crescent Dunes Solar } \\
\text { Energy Project } \\
\text { (Tonopah) }\end{array}$ & $\begin{array}{l}\text { Tonopah, } \\
\text { Nevada }\end{array}$ & $\begin{array}{l}\text { SolarReserve's } \\
\text { Tonopah Solar } \\
\text { Energy, LLC }\end{array}$ & $\begin{array}{l}\text { Net: } 110.0 \\
\text { Gross: } 110.0\end{array}$ & Operational \\
\hline $\begin{array}{l}\text { Nevada Solar One } \\
\text { (NSO) }\end{array}$ & $\begin{array}{l}\text { Boulder City, } \\
\text { Nevada }\end{array}$ & Acciona Energía & $\begin{array}{l}\text { Net: } 72.0 ; \\
\text { Gross: } 75.0\end{array}$ & Operational \\
\hline $\begin{array}{l}\text { Stillwater GeoSolar } \\
\text { Hybrid Plant }\end{array}$ & Fallon, Nevada & Enel Green Power & $\begin{array}{l}\text { Net: } 2.0 ; \\
\text { Gross: } 2.0\end{array}$ & Operational \\
\hline Tooele Army Depot & Tooele, Utah & Tooele Army Depot & $\begin{array}{l}\text { Net: } 1.5 ; \\
\text { Gross: } 1.5\end{array}$ & Operational \\
\hline
\end{tabular}

\subsubsection{Small Modular Reactors}

Commercial nuclear reactors to date have been used primarily for power production, but interest has increased in applying SMR and other advanced reactor technologies for process heat. Some 
possible configurations for transferring heat from a nuclear reactor(s) to the industrial user facility were previously studied under the NGNP program. An overview of this work and present research and development needs is summarized in a program plan for N-R HES (Brag-Sitton et al. 2016).

The concept of an SMR originated in the 1970s for developing merchant ship propulsion and industrial process heat applications. Current commercial development of SMRs hopes to have operating reactors within 10 to 15 years. SMRs have the following potential advantages over conventional nuclear reactors (Bolden et al. 2014, Carelli 2015):

- Safety: SMRs have inherent passive safety features, higher safety margin from natural disasters and man-made impacts, and better seismic isolation.

- Cost: The modularity, reduced finance costs, and faster revenue potential capabilities expect to reduce the capital, manufacturing, and operating costs of SMRs. Other factors such as shared infrastructure, production and fabrication cost, construction schedule, and cost of debt favor lower costs with respect to SMRs.

- Enhanced availability: SMRs are likely to have enhanced availability in that multiple units on a site would allow fewer units to be refueled at one time while the other units continue to operate.

- Enhanced utility: Small units allow for more diverse operations such as distributed power or power generation in remote or isolated areas.

- Proliferation resistance and safety: Many of the SMR designs place the reactor underground, lessening security risks.

Table 10 lists many of the SMR concepts that are being developed in the United States and abroad. SMR development spans all types of reactors; for example, light-water reactors (LWRs), high-temperature gas reactors (HTGRs), liquid-metal reactors, and molten-salt reactors. The thermal capacities of these examples range from 30 to $1,000 \mathrm{MW}$. The temperature of the potential process heat varies from $300^{\circ} \mathrm{C}$ for LWRs up to $850^{\circ} \mathrm{C}$ for HTGRs.

Table 10. Summary of International SMR Development

\begin{tabular}{|l|l|l|l|}
\hline Developer & $\begin{array}{l}\text { Reactor } \\
\text { Size }\left(\mathbf{M W}_{\mathbf{t}}\right)\end{array}$ & $\begin{array}{l}\text { Primary } \\
\text { Coolant }\end{array}$ & $\begin{array}{l}\text { Reactor } \\
\text { Outlet } \\
\text { Temperature } \\
\left.\mathbf{(}^{\circ} \mathbf{C}\right)\end{array}$ \\
\hline $\begin{array}{l}\text { National Atomic Energy Commission : } \\
\text { Central Argentina de Elementos } \\
\text { Modulares (CAREM) }\end{array}$ & 100 & Light Water & 326 \\
\hline $\begin{array}{l}\text { China National Nuclear Cooperation: } \\
\text { ACP-100 }\end{array}$ & 310 & Light Water & 303 \\
\hline $\begin{array}{l}\text { China National Nuclear Cooperation: } \\
\text { CNP-300 }\end{array}$ & 1,000 & Light Water & 302 \\
\hline Flexblue (France) & 600 & Light Water & 310 \\
\hline Korea Atomic Energy Research Institute: & 300 & Light Water & 323 \\
\hline
\end{tabular}




\begin{tabular}{|l|l|l|l|}
\hline $\begin{array}{l}\text { System Integrated Modular Advanced } \\
\text { Reactor (SMART) }\end{array}$ & & & \\
\hline Russian Federation: ABV-6M & 38 & Light Water & 330 \\
\hline Russian Federation: KLT-40S & 150 & Light Water & 316 \\
\hline Russian Federation: RITM-200 & 175 & Light Water & 295 \\
\hline Russian Federation: VBER-300 & 900 & Light Water & 328 \\
\hline Generation mPower (US): mPower & 530 & Light Water & 320 \\
\hline NuScale (US) & 160 & Light Water & 300 \\
\hline HOLTEC: SMR-160 & 525 & Light Water & 316 \\
\hline Westinghouse Electric Company: W-SMR & 800 & Light Water & 310 \\
\hline $\begin{array}{l}\text { BhaBha Atomic Research Center: } \\
\text { AHWR-300-LEU }\end{array}$ & 920 & Light Water & 288 \\
\hline $\begin{array}{l}\text { Nuclear Power Corporation of India Ltd:: } \\
\text { PHWR-220 }\end{array}$ & 755 & Heavy Water & 293 \\
\hline $\begin{array}{l}\text { Institute of Nuclear and New Energy } \\
\text { Technology: HTR-PM (India) }\end{array}$ & 250 & Helium & 750 \\
\hline $\begin{array}{l}\text { Pebble Bed Modular Reactor: PBMR-CG } \\
\text { (South Africa) }\end{array}$ & 250 & Helium & 750 \\
\hline General Atomics: GT-MHR (US) & 350 & Helium & 750 \\
\hline \begin{tabular}{l} 
General Atomics: EM (US) \\
\hline Toshiba/Westinghouse: 4S (Japan)
\end{tabular} & 500 & Helium & 850 \\
\hline Russian Federation: SVBR-100 & 280 & Sodium & 510 \\
\hline Inherently Safe Module (PRISM) (US) & 500 & Sodium- & 500 \\
\hline Source: Ingersoll 2015 & 500 \\
\hline
\end{tabular}

Source: Ingersoll 2015

The SMART reactor from Korea will be used for power production and water desalination using a multi-effect distillation plant. The plant will use process heat to operate the distillation process to provide potable water. The AHWR-300 plant under development in India is also planned to provide the energy necessary to produce demineralized make up water for AHWR using low temperature multi effect desalination plant of $500 \mathrm{~m}^{3}$ capacity per day (BARC, 2016). The NGNP program considered numerous process-heat applications in which the HTGR can provide heat to produce products such as ammonia, methanol, liquid fuels, olefins, and hydrogen.

Heat from SMRs can be extracted from three primary locations: the reactor outlet, the turbines within the power-conversion unit, and heat rejected at condensers or ambient coolers. The location of heat extraction depends on industry-specific needs, and whether the plant will provide CHP or electricity to the grid in a hybrid fashion. In either case, heat-transfer loops parallel to the power-conversion unit can transfer thermal energy to the industrial user. 
Some industrial plant applications, such as steam-methane reforming and methanol production, require high-temperature heat of $\sim 800^{\circ} \mathrm{C}$. This requires heat-transfer systems that are designed to handle hot gases. It is assumed such applications will occur in close proximity to the plant. Figure 19 shows a simple block flow diagram indicating heat delivery to the primary reformer in a natural gas reforming plant. In the example, the primary coolant for the fluoride-salt cooled high temperature reactor (FHR) is used to heat helium. The hot helium replaces the hot gas produced by natural gas combustion, which in some reforming plants consumes as much as $30 \%$ of the natural gas input to the plant. The helium loop also provides separation of the primary reactor coolant from the chemical plant.

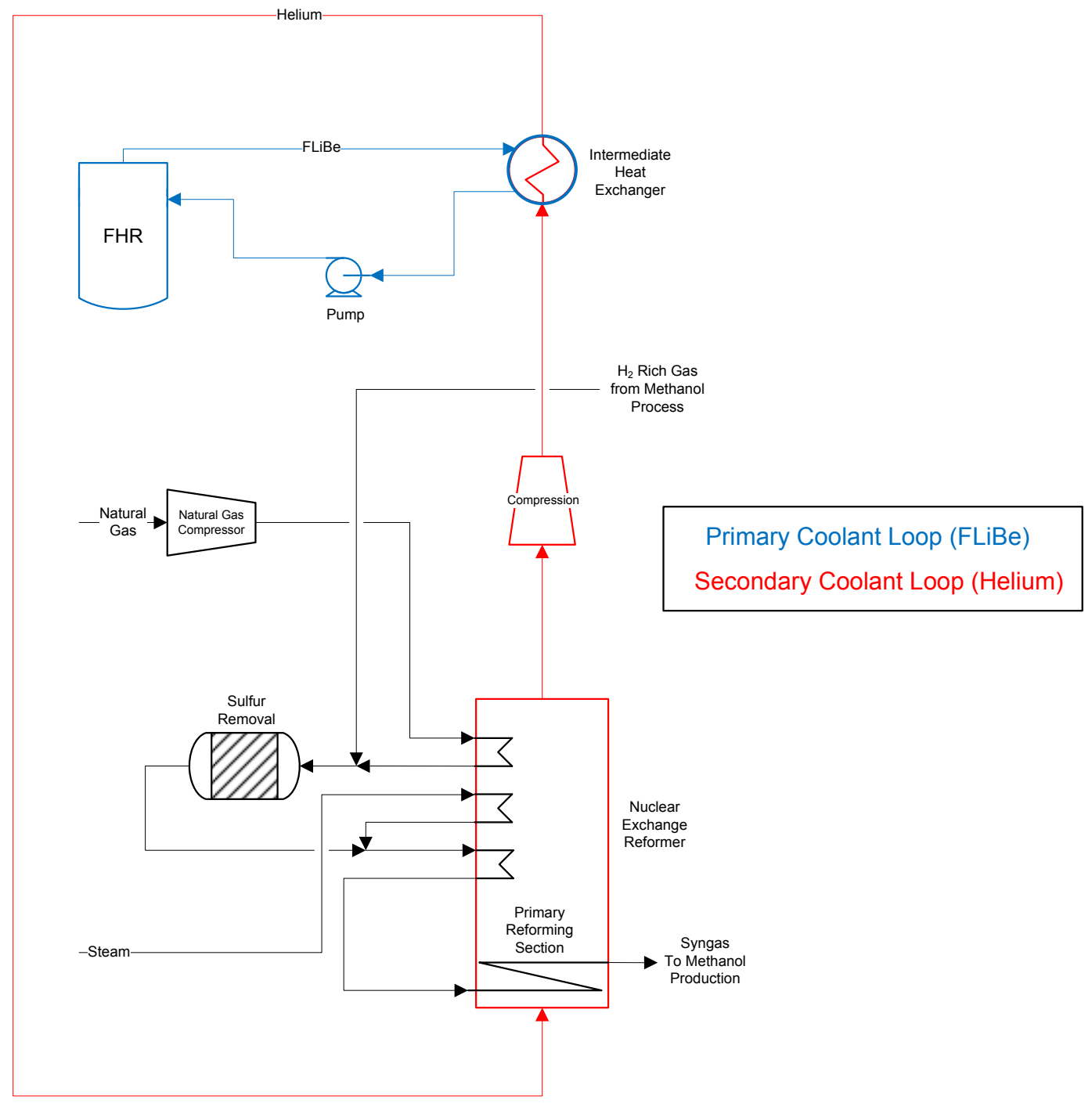

Figure 19. Integrated fluoride-salt cooled high temperature reactor (FHR) and steam-methane reforming reactor

(Wood and McKellar 2013)

Many process-heat applications require temperatures $<300^{\circ} \mathrm{C}$; for example, minerals drying and multi-effect evaporation. This temperature level is well suited for all SMRs. In the case of hightemperature reactors, the process heat extracted from turbines within the power-conversion unit 
may be used to provide such quality of heat. Extracting steam from turbines is a common practice for industrial processes.

Heat rejected by the power-conversion unit, either within a condenser or an ambient cooler, may be used for applications such as district heating. Although the amount of heat is large (up to twothirds of the reactor heat), the availability of useful heat is limited due to its low temperature, $<100^{\circ} \mathrm{C}$.

Hydrogen production via high-temperature steam electrolysis has been modeled for a variety of reactor types. High-temperature steam electrolysis requires $800^{\circ} \mathrm{C}$ steam to pass through the solid-oxide electrolysis cells to produce oxygen and hydrogen. The high-temperature steam reduces the work into the cells (electricity) and thereby makes the process more efficient than low-temperature electrolysis. A sweep gas such as air or steam is used to remove the oxygen generated in the cells. Through the use of low-temperature and high-temperature recuperation, the reactor heat, ranging from temperatures of $300^{\circ} \mathrm{C}$ to $850^{\circ} \mathrm{C}$, may be used to heat the process and sweep streams. The reactor heat is applied between the low-temperature and hightemperature heat recuperation. The heat from the reactor is used primarily to heat the process and sweep streams from a liquid state to a vapor state. Through the use of recuperation, only a small amount of topping heat is required to meet the conditions of the hydrogen cells. This heat can be supplied as electric heat without significantly affecting the efficiency of the hydrogen production (Wood and McKellar 2013; McKellar 2010). Analyses indicate that the reactor outlet temperature primarily affected the power-production efficiency and, therefore, the hydrogenproduction efficiency.

Preliminary plant-design simulation studies illustrate the potential use of nuclear heat in methanol production (Wood \& McKellar 2013). The reactor heat needed for such substitution will need to be derived from higher-temperature reactors such as FHRs and HTGRs.

\subsubsection{Geothermal}

Traditionally, geothermal energy has been used as a baseload power source among renewables. It is also being looked as a potential flexible power source, balancing intermittent wind and solar power production and reducing variability in energy price and as a heat source for non-electrical applications (DOE 2016b). Currently, geothermal energy constitutes less than $1 \%$ of the total U.S. electricity generation, and it is mainly located in the western states in the mountainous regions associated with active tectonic plate movement and near volcanic hot spots. Since 2005, the United States has built over 38 geothermal power projects, adding nearly $700 \mathrm{MWe}$ to the U.S. electricity capacity. Table 11 details the installed geothermal capacity, in $\mathrm{MW}_{\mathrm{e}}$, by state as of February 2013. Figure 20 shows the current developing planned capacity additions and nameplate capacity by state.

Table 11. Installed U.S. Geothermal Capacity as of $2013^{2}$

\begin{tabular}{|lll|}
\hline State & Capacity (MWe) & Share of U.S. total (\%) \\
\hline California & $2,732.20$ & 80.70 \\
\hline Nevada & 517.50 & 15.30 \\
\hline Utah & 48.10 & 1.40 \\
\hline
\end{tabular}




\begin{tabular}{|lll|}
\hline State & Capacity (MWe) & Share of U.S. total (\%) \\
\hline Hawaii & 38.00 & 1.10 \\
\hline Oregon & 33.30 & 1.00 \\
\hline Idaho & 15.80 & 0.50 \\
\hline New Mexico & 4.00 & 0.10 \\
\hline Alaska & 0.70 & $<0.10$ \\
\hline Wyoming & 0.30 & $<0.10$ \\
\hline Total & 3389.9 & 100 \\
\hline
\end{tabular}

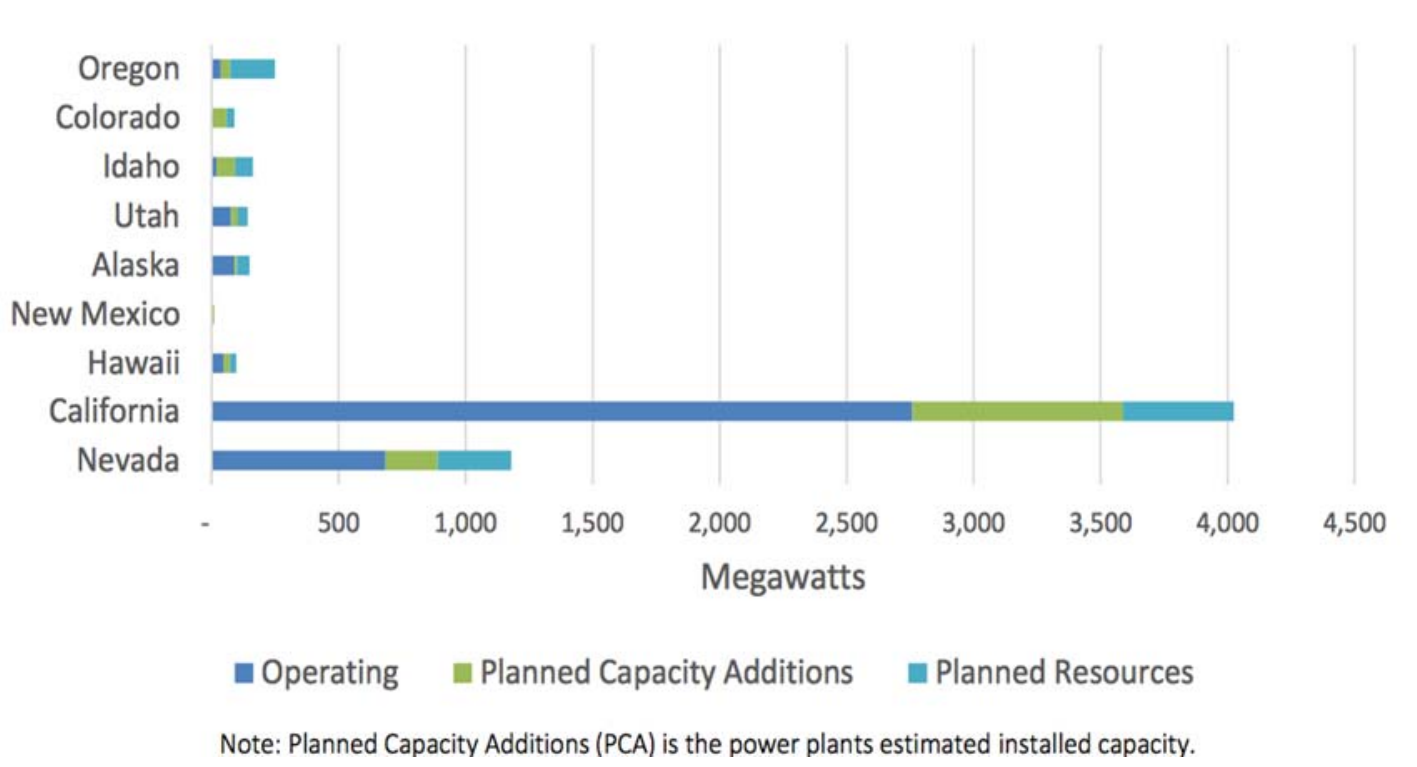

Figure 20. Planned capacity additions and nameplate capacity by state

Source: Geothermal Energy Association (2016)

Geothermal energy systems have a high availability factor with inherent storage capability. This attribute makes geothermal energy amenable for several heating applications. For example, agricultural and aquacultural applications require temperatures from $25-90^{\circ} \mathrm{C}$; space heating requires temperatures in the range of $50-100^{\circ} \mathrm{C}$; cooling and industrial processing require temperatures over $100^{\circ} \mathrm{C}$ (Lund 1996); drying and dehydration are other possible uses of geothermal energy, with application in manufacturing chemical industry such as pulp/paper and petroleum industry which could utilize a heating media with a temperature in the range of 150$200^{\circ} \mathrm{C}$ (Tester 2005). For example, the largest direct geothermal energy resource user in the world is Norske Skog Tasman pulp and paper mill at Kawerau, New Zealand, which uses geothermal fluids to generate steam $\left(0.7 \mathrm{MPa}, 171^{\circ} \mathrm{C}\right)$ for paper drying, a heat source for evaporators, and for electricity generation (White 2006).

Geothermal resource can be categorized in three dimensions: temperature, depth, and permeability/porosity (Tester 2005). Conventional production of electricity is generally limited to 
fluid temperatures above $150^{\circ} \mathrm{C}$, but considerably lower temperatures down to about $70^{\circ} \mathrm{C}$ can also be used with the application of binary fluids (Fridleifsson 1996). Geothermal production wells are commonly up to $2 \mathrm{~km}$ deep. The temperature rise with increasing depth in the crust averages about $25-30^{\circ} \mathrm{C} / \mathrm{km}$. This is referred to as the geothermal gradient (Tester 2005).

An assessment carried out by United States Geological Survey (USGS) estimated that the electric power generation potential from identified geothermal systems is about $9 \mathrm{GWe}_{\mathrm{e}}$ distributed over 13 states (Alaska, Arizona, California, Colorado, Hawaii, Idaho, Montana, Nevada, New Mexico, Oregon, Utah, Washington, and Wyoming). Resources were categorized as moderate-temperature $\left(90-150^{\circ} \mathrm{C}\right)$ and high-temperature (greater than $150^{\circ} \mathrm{C}$ ) geothermal systems located on both private or accessible public lands (Williams et al. 2008), as shown in . Low-temperature (below $150^{\circ} \mathrm{C}$ ) and co-produced resources represent a small but growing sector of geothermal development (DOE 2016b).

Figure 21 shows the locations of existing and potential hydrothermal sites and locations favorable to deep enhanced geothermal systems, these systems are created where hot rock is present but has insufficient or little natural permeability or fluid saturation (DOE 2016b; Augustine 2011). A summary of the results of the DOE geothermal resource potential capacity estimate for the United States is shown in Table 12. However, geophysical tools still lack the ability to accurately identify and remotely predict temperatures at target depths; thus, a geothermal resource is not confirmed until a well is drilled into a target reservoir, which could be a substantial upfront investment cost. 


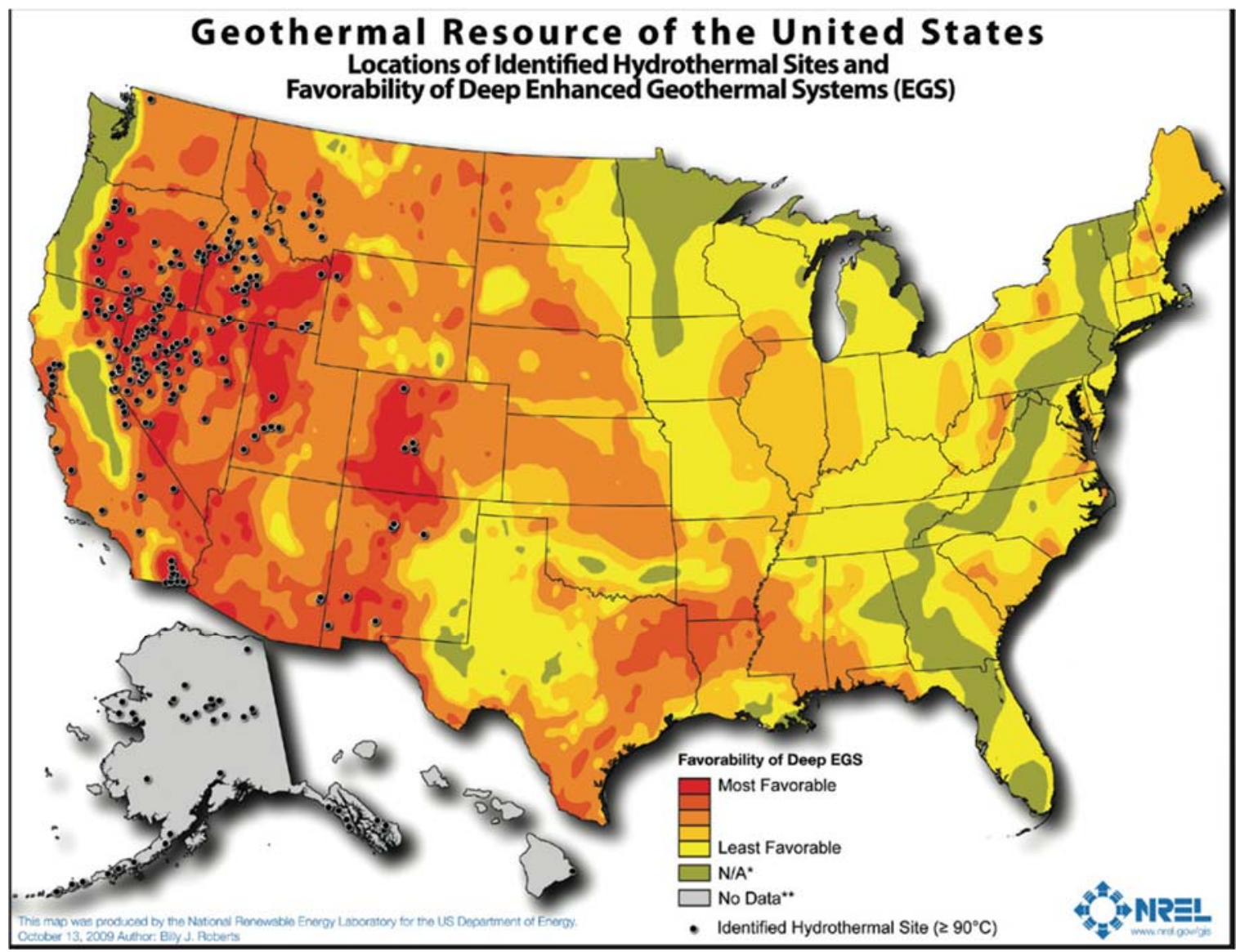

Figure 21. Geothermal resources of the United States (DOE 2016b) 
Table 12. Summary of U.S. Geothermal Resource Potential (Augustine 2011)

\begin{tabular}{|c|c|c|c|}
\hline \multicolumn{2}{|c|}{ Resource } & \multicolumn{2}{|r|}{ Resource Potential } \\
\hline & & $\begin{array}{c}\text { Capacity } \\
\left(G W_{e}\right)\end{array}$ & Source(s) and Description \\
\hline \multirow[t]{2}{*}{ Hydrothermal } & $\begin{array}{c}\text { Identified } \\
\text { Hydrothermal } \\
\text { Sites }\end{array}$ & 6.39 & $\begin{array}{l}\text { USGS } 2008 \text { Geothermal Resource Assessment }{ }^{1} \\
\text { - Identified hydrothermal sites } \\
\text { - Sites } \geq 110^{\circ} \mathrm{C} \text { included } \\
\text { - Currently installed capacity excluded }\end{array}$ \\
\hline & $\begin{array}{l}\text { Undiscovered } \\
\text { Hydrothermal }\end{array}$ & 30.03 & USGS 2008 Geothermal Resource Assessment ${ }^{1}$ \\
\hline \multirow{2}{*}{$\begin{array}{l}\text { Enhanced } \\
\text { Geothermal } \\
\text { Systems } \\
\text { (EGS) }\end{array}$} & $\begin{array}{c}\text { Near- } \\
\text { Hydrothermal } \\
\text { Field EGS }\end{array}$ & 7.03 & $\begin{array}{l}\text { Based on data from USGS } 2008 \text { Geothermal } \\
\text { Resource Assessment }{ }^{1} \text { and methodology developed } \\
\text { at NREL } \\
\text { - Regions near identified hydrothermal sites } \\
\text { - Sites } \geq 110^{\circ} \mathrm{C} \text { included } \\
\text { - Difference between mean and } 95 \% \text { ile } \\
\text { hydrothermal resource estimate }\end{array}$ \\
\hline & Deep EGS & 15,908 & $\begin{array}{l}\text { NREL } 2006 \text { Update }^{2} \text {, MIT Report }{ }^{3}, \text { SMU Data } \\
\text { - Based on volume method of thermal energy in } \\
\text { rock } 3-10 \mathrm{~km} \text { depth and } \geq 150^{\circ} \mathrm{C} \\
\text { - Does not consider economic or technical } \\
\text { feasibility }\end{array}$ \\
\hline $\begin{array}{l}1 \text { (Williams, Reed, } \\
{ }^{2} \text { (Petty and Porro } 2 \\
{ }^{3} \text { (Tester et al. 2006 } \\
{ }^{4} \text { (Richards 2009) }\end{array}$ & $\begin{array}{l}\text { et al. 2008b) } \\
\text { 2007) }\end{array}$ & & \\
\hline
\end{tabular}

U.S. distribution of potential geothermal energy use versus heat-application temperature has also been projected by Tester (2005), who indicates the total amount of energy use below $250^{\circ} \mathrm{C}$ is equal to $31.7 \mathrm{EJ}$ (30 quads, or 8,800 TWh).

Unlike wind and solar resources, which are more dependent on weather fluctuations and climate changes, geothermal resources tend to have a much higher capacity factor, while the common medium for geothermal energy source is water, which in some parts of the country is sparse and is a much valued commodity. A different heat-transport medium, such as $\mathrm{CO}_{2}$, is being studied that has been indicated to potentially be superior to water in achieving larger heat-extraction rates when the same injection pressure is applied; however, the challenge lies in the need for the reservoir to be completely dry before $\mathrm{CO}_{2}$ is injected to avoid formation of carbonic acid (DOE $2015 \mathrm{e}$ ). One of the inherent challenges with geothermal energy is that it cannot be moved or transported to generation sites or near an industry compared to the alternative sources; it must be located in regions with advantageous subsurface conditions, which do not always coincide with the locations of the industries.

To advance the geothermal technology such that cost and risks associated could be reduced, ways to derive more value from the resource need to be identified and developed. Key areas 
identified in the U.S. DOE Quadrennial Technology Review that have the potential to impact geothermal deployment are: resource characterization and exploration technologies, control of subsurface fracturing and flow, improved subsurface access technologies, and additional value added to operations through mineral recovery and hybrid systems (DOE 2015e). Frontier Observatory for Research in Geothermal Energy (FORGE), a DOE initiative, is designed to address some of these areas and potentially become a dedicated test site. Going forward, geothermal plants with high availability and reliability could also: ramp up and ramp down electricity generation output, providing flexibility and ancillary services; provide heat/thermal energy to drive lower-temperature applications; and also, provide a source of elements for industries, thus expanding its market value beyond just power production and making them more commercially viable.

\subsubsection{Heat Use Comparison}

This section projects the potential opportunity to use SMR, SIPH, and geothermal heat in the top 14 industries. Currently SMR technology is being developed to provide thermal heat ranging from $300-850^{\circ} \mathrm{C}$. Assuming that the smallest practical SMR module is $150 \mathrm{MW}_{\mathrm{t}}$, then $403 \mathrm{SMR}$ units could provide 1,900 PJ/yr heat demand to the target industries as shown in Figure 14. The potential temperature limit for SIPH has not been established, but it may be assumed that the practical range will be limited to $850^{\circ} \mathrm{C}$ for the same materials issues that impact SMR output and heat circulation. Assuming the scale of $\mathrm{SIPH}$ is limited to an upper size of $250 \mathrm{MW}_{\mathrm{t}}$, then SIPH could supply as much as 2,000 PJ/yr to the 14 industries. Geothermal heat conditions are set by the environmental conditions, but currently operate at temperatures up to $150^{\circ} \mathrm{C}$. At this temperature limit geothermal energy could support $180 \mathrm{PJ} / \mathrm{yr}$ of industrial heat.

Table 13. Summary of Heat Generators and Potential Industrial Users

\begin{tabular}{|l|c|l|l|}
\hline $\begin{array}{l}\text { Heat } \\
\text { Generators }\end{array}$ & $\begin{array}{l}\text { Assumed Avg. } \\
\text { Heat Output } \\
\left(\mathbf{M W}_{\mathbf{t}}\right)\end{array}$ & $\begin{array}{l}\text { Available Expected } \\
\text { Temperature }\left({ }^{\circ} \mathbf{C}\right)\end{array}$ & Industries \\
\hline $\begin{array}{l}\text { SIPH (CSP) } \\
\text { Units }\end{array}$ & $1-100$ & $\begin{array}{l}\text { Not determined in this } \\
\text { study, assumed limit is } \\
1000^{\circ} \mathrm{C}\end{array}$ & $\begin{array}{l}\text { Petroleum refineries, chemical } \\
\text { industries, paper and paperboard } \\
\text { mills, ethyl alcohol, alkali and } \\
\text { chlorine, potash, and soda and } \\
\text { borate mining }\end{array}$ \\
\hline $\begin{array}{l}\text { Geothermal } \\
\text { Units }\end{array}$ & $1-50$ & 150 & $\begin{array}{l}\text { Paper and paperboard mills, pulp, } \\
\text { ethyl alcohol, and wet corn milling }\end{array}$ \\
\hline SMR Units & $100-600$ & $300-850$ & $\begin{array}{l}\text { Petroleum refineries, chemical } \\
\text { industries, paper and paperboard } \\
\text { mills, ethyl alcohol, alkali and } \\
\text { chlorine, potash, and soda and } \\
\text { borate mining }\end{array}$ \\
\hline
\end{tabular}

* Advanced materials development will support high temperature gas-cooled SMR temperatures up to $950^{\circ} \mathrm{C}$.

Based on the assumed average heat capacity for SMRs and temperature requirement within different industries, the number of required units to meet total industrial thermal (heat) needs is shown in Table 14. The number of SMRs for petroleum and the iron and steel mills also include those dedicated to hydrogen production using high temperature steam electrolysis. For a LWR SMR, $439 \mathrm{MWt} /(\mathrm{kg} / \mathrm{s}$ of hydrogen 
produced) is used to estimate the SMR number. For the iron and steel mills, $83 \mathrm{~kg}$ of hydrogen per ton of steel produced can be used to replace the coke used within the refineries.

Table 14. Number of SMR Units (150 MWt scale) required to meet Selected Industrial Needs

\begin{tabular}{|c|c|c|c|c|c|}
\hline Industry Subsector & Target Industry & $\begin{array}{c}\text { Heat Input } \\
\left(\mathbf{M W}_{\mathrm{t}}\right)\end{array}$ & $\begin{array}{c}\text { Number of } \\
\text { Plants }\end{array}$ & $\begin{array}{l}\text { Number } \\
\text { of SMRs }\end{array}$ & $\begin{array}{c}\text { Hydrogen } \\
\text { (tonnes/day) }\end{array}$ \\
\hline Petroleum and Coal Products & Petroleum Refineries & 13,456 & 141 & 399 & 9,130 \\
\hline Primary Metal Manufacturing & Iron and Steel Mills & 3,225 & 115 & 226 & 6,690 \\
\hline \multirow{2}{*}{ Paper Manufacturing } & $\begin{array}{c}\text { Paper \& Paper-Board } \\
\text { Mills }\end{array}$ & 20,799 & 189 & 139 & \\
\hline & Pulp Mills & 1,496 & 30 & 10 & \\
\hline \multirow{5}{*}{ Chemical Manufacturing } & $\begin{array}{l}\text { All other Basic } \\
\text { Chemical } \\
\text { Manufacturing } \\
\text { (Methanol) }\end{array}$ & 12,714 & 85 & 85 & \\
\hline & $\begin{array}{l}\text { Ethyl Alcohol } \\
\text { Manufacturing }\end{array}$ & 3,445 & 168 & 23 & \\
\hline & $\begin{array}{c}\text { Petrochemical } \\
\text { Manufacturing } \\
\text { (Ethylene) }\end{array}$ & 962 & 35 & NA & \\
\hline & $\begin{array}{l}\text { Alkalies and Chlorine } \\
\text { Manufacturing }\end{array}$ & 545 & 11 & 4 & \\
\hline & $\begin{array}{l}\text { Nitrogenous Fertilizer } \\
\text { Manufacturing } \\
\text { (Ammonia) }\end{array}$ & 2,448 & 30 & 16 & \\
\hline Food Manufacturing & Wet Corn Milling & 2,239 & 24 & 15 & \\
\hline \multirow{2}{*}{$\begin{array}{l}\text { Nonmetallic Mineral Product } \\
\text { Manufacturing }\end{array}$} & Lime & 1,728 & 49 & NA & \\
\hline & Cement & 12,760 & 117 & NA & \\
\hline Mining (Except Oil and Gas) & Soda Ash & 3,318 & 11 & 22 & \\
\hline
\end{tabular}

*NA refers to not applicable, as the required temperature of the respective industry is higher than available temperature range between $300-$ $850^{\circ} \mathrm{C}$ from SMR. For number of units, SMR of $150 \mathrm{MW}$ has been utilized. The reason for not including number of required units for geothermal and SIPH plants is because of large variability in available heat capacity.

\subsection{Heat Transport}

This section focuses on heat-transport systems that can potentially link nuclear and concentrating solar systems to industrial processes. 


\subsubsection{Heat-Transfer Fluids}

Table 15 lists some of the properties and characteristics of common heat-transfer working fluids that are used by the petrochemical and chemical industries. The selected industrial application and its corresponding temperature requirement dictate which fluid may be used to transfer thermal energy. The key fluid decision discriminators include: heat-transfer capacity, rheological properties, availability of the fluid, material compatibility, and cost. The selection of the best heat-transfer fluid considers:

- Temperature of process-unit operation

- Heat-exchange method: direct versus indirect contact with the process reactor, heatexchanger design (e.g., gas or liquid circulation compatibility)

- Economics: cost and availability of the heat-transfer fluid, pumping costs, thermal stability, and retrofit or new process reactor design cost-benefit feasibility

- Heat-transfer properties: heat capacity and thermal conductivity, freezing/melting point, and heat-transfer coefficient

- Rheological properties: density, kinematic viscosity, and compressibility

- Technical compatibility: corrosivity of heat-delivery system, reactivity with process reactants, and volatility

- Safety: toxicity and reactivity with air or water.

The previous section indicates that industry heating is largely based on pressurized hot water and superheated steam-circulation systems. However, two-phase, thermally stable, synthetic organic heat-transfer fluids (e.g., Dowtherm) are also popular because they may avoid corrosion issues associated with steam systems. Some synthetic fluids may have better heat-transfer coefficients, considering fluid viscosity, specific heat, density, and thermal conductivity. Non-aqueous heattransfer fluids are also preferred for winter conditions and they can avoid pipe corrosion.

Inorganic salts and liquid metals also provide a practical heat-transfer media. They can be heated electrically or with a fired heater.

For process temperatures below $600-650^{\circ} \mathrm{C}$, steam has many advantages:

- Steam is an inexpensive and common heat-transport fluid and has a long history as a heat-transfer fluid.

- After the heat is transferred to the process, the steam condenses to water, which greatly reduces power required to recirculate the heat-transfer fluid. Pumping water requires less power than recirculating a gas.

- Steam has one of the highest heat capacities at higher pressures (comparable to molten salts) as shown in Table 15.

- Steam has a low freezing point compared to molten salts and metals.

Gases that are heated by an external heat-generation source or an electrical heater can readily replace steam and hot combustion gases that are passed through reactor-vessel coils or jackets. 
Helium has a relatively high heat capacity and thermal conductivity compared to other gases. It is generally not prone to metals oxidation and interaction, although studies have shown that helium strips carbon from high-temperature alloys unless trace amounts of carbon monoxide are added to the gas. The downside to helium may be its cost and operating pressure requirements. Helium is only produced by nuclear processes. Naturally occurring helium has accumulated over previous geological periods and is now mainly found in natural gas reservoirs. Therefore, it must be separated and supplied for heat applications in amounts that could exceed future production capacity. Unlike steam, which can be generated from pressurized water and can be circulated with a pump, helium must be compressed to force circulation. Additionally, helium is pressurized and circulated at high velocities to increase the heat-transfer rate when used for process-heating applications. Liquid metals and molten salts have very high heat capacities and can efficiently transport heat over long distances because liquid pumps require significantly less energy than gas compressors.

Table 15 lists only a few of the metals and salts that have been investigated for nuclear and SIPH systems. The main advantages of liquid metals are the very high heat capacities, comparatively low viscosities, and low corrosion performance characteristics. Sodium, in particular, is practically noncorrosive to stainless steel. Sodium exhibits a relatively high vapor pressure at temperatures approaching its boiling temperature of $883^{\circ} \mathrm{C}$. Liquid lead and lead-bismuth have much high boiling temperatures $\left(1,737^{\circ} \mathrm{C}\right.$ and $\sim 1,670^{\circ} \mathrm{C}$, respectively); however, they exhibit aggressive corrosion by direct dissolution by surface reactions, and therefore, they can only be operated at fluid velocities less than 3 meters per second. The chief concern of liquid metals, however, is reaction with air and water and is a known concern. Molten salts are gaining popularity for both nuclear reactors and CSP systems. A recent review of the characteristics of molten salts lists the benefits of salts relative to liquid metals and gases (Yoon et al. 2014; McKellar et al. 2011). The most common salts that are being proposed for heat transfer in these systems are alkali-based nitrates and carbonated, zirconia-based fluorides and chlorides. Only a few of these salts are listed in Table 14 for illustrative purposes.

Molten salts also exhibit the highest volumetric-specific heat capacities. Some can operate at very high temperatures without decomposing, although nitrate and carbonate salts are an exception. Solar salt $\left(\mathrm{NaNO}_{3} \mathrm{KNO}_{3}\right)$, for example, becomes thermally unstable around $600^{\circ} \mathrm{C}$. In comparison, mixtures of alkalis-fluorides-zirconium carbonates are thermally stable at temperatures exceeding $900^{\circ} \mathrm{C}$. The downside of molten salts includes the propensity for corrosion, particularly with the fluoride and chloride salts. Consequently, corrosion will continue as an important topic for emerging nuclear reactors and CSP technology.

Table 15. Properties and Characteristics of Common Heat-Transfer Working Fluids

\begin{tabular}{|c|c|c|c|c|c|c|c|}
\hline Name & $\begin{array}{c}\text { Specific } \\
\text { Heat } \\
\text { Capacity } \\
(\mathbf{k J} / \mathbf{k g}-\mathbf{K})\end{array}$ & $\begin{array}{l}\text { Thermal } \\
\text { Conductivity } \\
\text { (W/m-K) }\end{array}$ & $\begin{array}{l}\text { Dynamic } \\
\text { Viscosity } \\
(\mathrm{kg} / \mathrm{m}-\mathrm{s})\end{array}$ & $\begin{array}{l}\text { Density } \\
\left(\mathrm{kg} / \mathrm{m}^{3}\right)\end{array}$ & $\begin{array}{c}\text { Heat } \\
\text { Capacity } \\
\text { Density } \\
\left(\mathrm{kJ} / \mathrm{m}^{3}-\mathrm{K}\right)\end{array}$ & $\begin{array}{c}\text { Kinematic } \\
\text { Viscosity } \\
\left(\mathrm{m}^{2} / \mathrm{s}\right)\end{array}$ & $\begin{array}{c}\text { Temp. } \\
\text { melting/ } \\
\text { boiling } \\
\left({ }^{\circ} \mathrm{C}\right)\end{array}$ \\
\hline \multicolumn{8}{|c|}{ Two-Phase Fluids } \\
\hline \multicolumn{8}{|c|}{ Saturated Steam } \\
\hline @ 500 K & 3.27 & 4.23E-02 & $1.66 \mathrm{E}-05$ & 13.05 & 42.69 & 1.27E-06 & $0 / 227$ \\
\hline
\end{tabular}




\begin{tabular}{|c|c|c|c|c|c|c|c|}
\hline Name & $\begin{array}{l}\text { Specific } \\
\text { Heat } \\
\text { Capacity } \\
\text { (kJ/kg-K) }\end{array}$ & $\begin{array}{l}\text { Thermal } \\
\text { Conductivity } \\
\text { (W/m-K) }\end{array}$ & $\begin{array}{l}\text { Dynamic } \\
\text { Viscosity } \\
(\mathrm{kg} / \mathrm{m}-\mathrm{s})\end{array}$ & $\begin{array}{l}\text { Density } \\
\left(\mathrm{kg} / \mathrm{m}^{3}\right)\end{array}$ & $\begin{array}{c}\text { Heat } \\
\text { Capacity } \\
\text { Density } \\
\left(\mathrm{kJ} / \mathrm{m}^{3}-\mathrm{K}\right)\end{array}$ & $\begin{array}{c}\text { Kinematic } \\
\text { Viscosity } \\
\left(\mathrm{m}^{2} / \mathrm{s}\right)\end{array}$ & $\begin{array}{l}\text { Temp. } \\
\text { melting/ } \\
\text { boiling } \\
\left({ }^{\circ} \mathrm{C}\right)\end{array}$ \\
\hline \multicolumn{8}{|l|}{ (122 atm) } \\
\hline $\begin{array}{r}@ 625 \mathrm{~K} \\
(167 \mathrm{~atm})\end{array}$ & 18.3 & $1.21 \mathrm{E}-01$ & 2.70E-05 & 117.6 & 2153 & 2.30E-07 & $0 / 352$ \\
\hline \multicolumn{8}{|c|}{ Saturated Dowtherm Vapor } \\
\hline $\begin{array}{r}@ 530 \mathrm{~K} \\
(1 \mathrm{~atm})\end{array}$ & 1.835 & $2.40 \mathrm{E}-02$ & $1.00 \mathrm{E}-05$ & 4.003 & 7.346 & $2.50 \mathrm{E}-06$ & $12.0 / 257.1$ \\
\hline $\begin{array}{r}@ 668 K \\
(9.86 \mathrm{~atm})\end{array}$ & 2.286 & $3.58 \mathrm{E}-02$ & $1.34 \mathrm{E}-02$ & 39.25 & 89.73 & 3.41E-04 & $12.0 / 395$ \\
\hline \multicolumn{8}{|c|}{ Gases } \\
\hline \multicolumn{8}{|l|}{ Air } \\
\hline $\begin{array}{r}@ 500 \mathrm{~K} \& \\
1 \mathrm{~atm}\end{array}$ & 1.03 & 4.07E-02 & 2.70E-05 & 0.6964 & 0.7173 & 3.88E-05 & NA \\
\hline $\begin{array}{r}@ 1000 \mathrm{~K} \& \\
1 \mathrm{~atm}\end{array}$ & 1.141 & 6.67E-02 & $4.24 \mathrm{E}-05$ & 0.3482 & 0.3973 & $1.22 E-04$ & NA \\
\hline $\begin{array}{r}@ 500 \mathrm{~K} \& \\
98.7 \mathrm{~atm}\end{array}$ & 1.03 & 4.07E-02 & 2.70E-05 & 67.02 & 69.03 & 4.03E-07 & NA \\
\hline $\begin{array}{r}\text { @ } 1000 \mathrm{~K} \& \\
98.7 \mathrm{~atm}\end{array}$ & 1.141 & 6.67E-02 & 4.24E-05 & 33.74 & 38.50 & $1.26 \mathrm{E}-06$ & NA \\
\hline \multicolumn{8}{|l|}{ Carbon Dioxide } \\
\hline $\begin{array}{r}@ 500 \mathrm{~K} \& \\
1 \mathrm{~atm}\end{array}$ & 1.02 & $3.25 E-02$ & 2.31E-05 & 1.059 & 1.081 & 2.18E-05 & NA \\
\hline $\begin{array}{r}@ 1000 \mathrm{~K} \& \\
1 \mathrm{~atm}\end{array}$ & 1.22 & $6.79 \mathrm{E}-02$ & 4.55E-05 & 0.5362 & 0.6564 & 8.48E-05 & NA \\
\hline $\begin{array}{r}@ 500 \mathrm{~K} \\
\& 98.7 \mathrm{~atm}\end{array}$ & 1.17 & $3.86 \mathrm{E}-02$ & 2.86E-05 & 113.0 & 132.1 & 2.53E-07 & NA \\
\hline $\begin{array}{r}@ 1000 \mathrm{~K} \\
\& 98.7 \mathrm{~atm}\end{array}$ & 1.25 & 7.04E-02 & 4.64E-05 & 51.71 & 64.61 & 8.97E-07 & NA \\
\hline \multicolumn{8}{|l|}{ Helium } \\
\hline $\begin{array}{r}@ 500 \mathrm{~K} \& \\
1 \mathrm{~atm}\end{array}$ & 5.193 & $2.20 \mathrm{E}-01$ & 2.83E-05 & 0.09754 & 0.5065 & $2.90 \mathrm{E}-04$ & NA \\
\hline $\begin{array}{r}@ 1000 \mathrm{~K} \& \\
1 \mathrm{~atm}\end{array}$ & 5.193 & 3.54E-01 & 4.46E-05 & 0.04879 & 0.2534 & $9.14 \mathrm{E}-04$ & NA \\
\hline $\begin{array}{r}@ 500 \mathrm{~K} \& \\
98.7 \mathrm{~atm}\end{array}$ & 5.193 & $2.20 E-01$ & 2.83E-05 & 9.381 & 48.715 & $3.02 E-06$ & NA \\
\hline $\begin{array}{r}1000 \mathrm{~K} \& \\
98.7 \mathrm{~atm}\end{array}$ & 5.193 & 3.54E-01 & $9.14 \mathrm{E}-04$ & 4.762 & 24.73 & $1.92 E-04$ & NA \\
\hline \multicolumn{8}{|c|}{ Liquids and Salts } \\
\hline \multicolumn{8}{|l|}{ Sodium } \\
\hline @ 366 K & 1.39 & $8.62 E+01$ & $6.98 \mathrm{E}-04$ & 929.1 & 1291 & $7.52 \mathrm{E}-07$ & $97.8 / 883$ \\
\hline @ 977 K & 1.26 & $5.97 \mathrm{E}+01$ & $1.78 \mathrm{E}-04$ & 778.5 & 980.9 & $2.29 \mathrm{E}-07$ & $97.8 / 883$ \\
\hline
\end{tabular}




\begin{tabular}{|c|c|c|c|c|c|c|c|}
\hline Name & $\begin{array}{l}\text { Specific } \\
\text { Heat } \\
\text { Capacity } \\
\text { (kJ/kg-K) }\end{array}$ & $\begin{array}{l}\text { Thermal } \\
\text { Conductivity } \\
\text { (W/m-K) }\end{array}$ & $\begin{array}{l}\text { Dynamic } \\
\text { Viscosity } \\
\text { (kg/m-s) }\end{array}$ & $\begin{array}{l}\text { Density } \\
\left(\mathbf{k g} / \mathbf{m}^{3}\right)\end{array}$ & $\begin{array}{c}\text { Heat } \\
\text { Capacity } \\
\text { Density } \\
\left(\mathrm{kJ} / \mathrm{m}^{3}-\mathrm{K}\right)\end{array}$ & $\begin{array}{c}\text { Kinematic } \\
\text { Viscosity } \\
\left(\mathrm{m}^{2} / \mathrm{s}\right)\end{array}$ & $\begin{array}{l}\text { Temp. } \\
\text { melting/ } \\
\text { boiling } \\
\left({ }^{\circ} \mathrm{C}\right)\end{array}$ \\
\hline \multicolumn{8}{|l|}{ Lead-Bismuth } \\
\hline @ 561K & 0.147 & 10.7 & $1.76 \mathrm{E}-03$ & $1.03 E+04$ & 1514 & $1.71 \mathrm{E}-07$ & $125 / 1670$ \\
\hline @ 922 K & 0.147 & 2.7 & $1.15 \mathrm{E}-03$ & $9.84 \mathrm{E}+03$ & 1446 & 1.17E-07 & $125 / 1670$ \\
\hline \multicolumn{8}{|c|}{ Hitec XL $\left(\mathrm{NaNO}_{3} \mathrm{KNO}_{3} \mathrm{Ca}\left(\mathrm{NO}_{3}\right)_{2}\right.$} \\
\hline @ 575 K & 1.45 & 0.52 & 6.37E-03 & 1870 & 2712 & $3.41 \mathrm{E}-06$ & $120 / 500$ \\
\hline \multicolumn{8}{|l|}{ LiF-NaF-KF } \\
\hline @ $750 \mathrm{~K}$ & 1.77433 & 0.78 & $9.75 \mathrm{E}-03$ & 2111 & 3746 & 4.62E-06 & $450 / 1570$ \\
\hline @ $1000 \mathrm{~K}$ & 2.04018 & 0.92 & 2.19E-03 & 1955 & 3989 & $1.12 \mathrm{E}-06$ & $450 / 1570$ \\
\hline \multicolumn{8}{|l|}{$\mathrm{KF}-\mathrm{ZrF}_{4}$} \\
\hline @ 750 K & 1.051 & 0.32 & 1.10E-03 & 2751 & 2891 & 4.01E-07 & $390 / 1450$ \\
\hline @ $1000 \mathrm{~K}$ & 1.051 & 0.32 & $3.82 \mathrm{E}-04$ & 2529 & 2658 & $1.51 \mathrm{E}-07$ & $390 / 1450$ \\
\hline \multicolumn{8}{|l|}{$\mathrm{KCl}-\mathrm{MgCl}_{2}$} \\
\hline @ 750 K & 1.15 & 0.0931 & $2.88 \mathrm{E}-03$ & 2008.34 & 2310 & 1.43E-06 & $426 / 1418$ \\
\hline @ $1000 \mathrm{~K}$ & 1.15 & 0.1241 & 1.35E-03 & 1889.84 & 2173 & 7.16E-07 & $426 / 1418$ \\
\hline
\end{tabular}

In summary, steam and hot gases are currently compatible with the chemical process industries. Liquid metals and molten salts likely are not compatible with cast iron, ductile iron, and stainless-steel heat exchangers and reactor vessels/piping. Consequently, it is likely that a secondary or tertiary heat exchanger with a non-reactive heat-transfer media will be required for liquid-metal- and salt-cooled reactors.

\subsubsection{Heat-Transfer Distance}

Several factors govern the distance of the heat source to process unit operations:

1. Safety considerations.

2. Heat-source scale versus heat user demand (or the capacity-matching criterion)

3. Quality of heat required by the user (or temperature of the working fluid)

Given that safety is the highest priority, some important factors to consider for nuclear reactors include regulatory constraints and exclusion-zone considerations. A probabilistic risk assessment (PRA) is a guiding criterion. Compared to conventional LWR technology modern SMR designs tend to have reduced risk by two or three orders of magnitude, due to passive safety inherent characteristics and can be shown using PRA methods (NRC 2016). When collocated with a chemical plant, the PRA may need to call out the hazards of the chemical plant. An ammonia plant, for example, may have a specific stand-off distance required to protect the nuclear reactor operations and vice versa. 
Security of the nuclear plant and fuel storage operations is another issue to consider. Currently, a central storage location for commercial nuclear fuel does not exist. This issue is, however, being taken up by the DOE Office of Nuclear Energy with impetus from a recent LINE Commission on fuel handling and dispositioning in the United States (LINE 2016).

Technical considerations for heat-transfer distance, such as capacity matching and working fluid temperature, are straight forward, but not necessarily easy. The considerations could benefit from more research and development. Previous work concluded that steam/water and molten salts perform better than gases for relatively long heat-transfer distances (up to $20 \mathrm{~km}$ ), primarily because low-pressure gases such as helium require extremely high pumping power (McKellar 2011). The high pumping power makes long-distance hot-gas transport inefficient and economically nonviable for both low- and high-temperature applications (Yoon et al. 2014; McKellar et al. 2011).

An illustrative example here demonstrates the technical analysis that is part of a technical/economic assessment of any industrial plan retrofit or new plant. A thermal hydraulic model was developed to compare the energy costs and heat-delivery capacity of a heat-transfer circulation loop for a nuclear reactor that is located about two kilometers from a process plant. In this case, it is assumed that a hot gas, namely helium, will circulate through a heating jacket at the chemical plant. The question that arises is whether it is most cost effective to position a secondary heat exchanger (molten salt/helium) in close proximity to the nuclear reactor, or adjacent to the chemical process vessel that will be heated by helium gas circulation.

Figure 22 and Figure 23 compare the transport of molten $\mathrm{KFZrF}_{4}$ to helium using a circulation loop of a comparable size. For this comparison, the pipe is considered to be buried, although this may not be practical when considering thermal-expansion design requirements. The molten salt, having the highest volumetric heat capacity and lowest pumping energy, is capable of transporting $54.4 \mathrm{TJ} /$ day or $629 \mathrm{MW}_{\mathrm{t}}$ (at a coefficient of performance of 4,670 $\mathrm{TJ} /$ day-MWe) versus $16.3 \mathrm{TJ} /$ day or $188 \mathrm{MW}_{\mathrm{t}}$ (at a coefficient of performance of $4.85 \mathrm{TJ} /$ day-MWe) using helium in the same sized piping system. The coefficient of performance is the heat divided by the pumping or compression power used to transport the heat. In a practical engineering design, pipe material and corrosion, as well as pump versus compressor costs, are important considerations. 


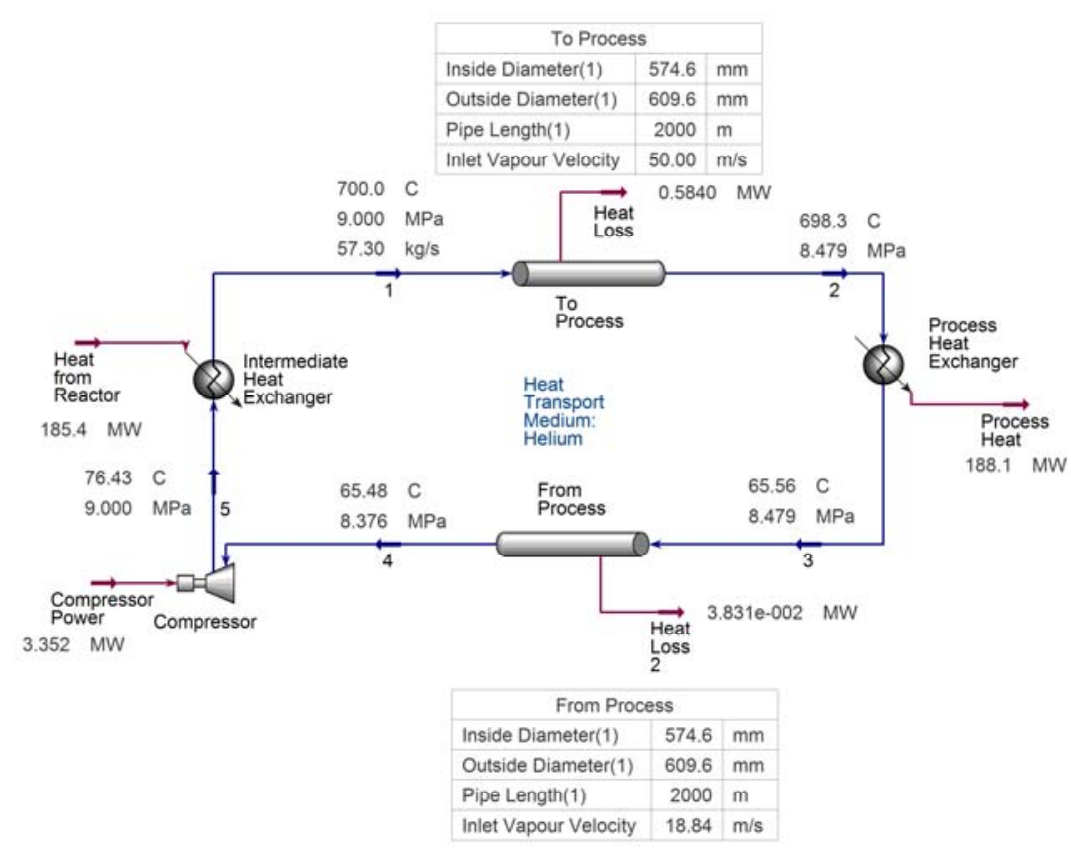

Figure 22. Operating conditions and performance of a 2-km helium circulation loop

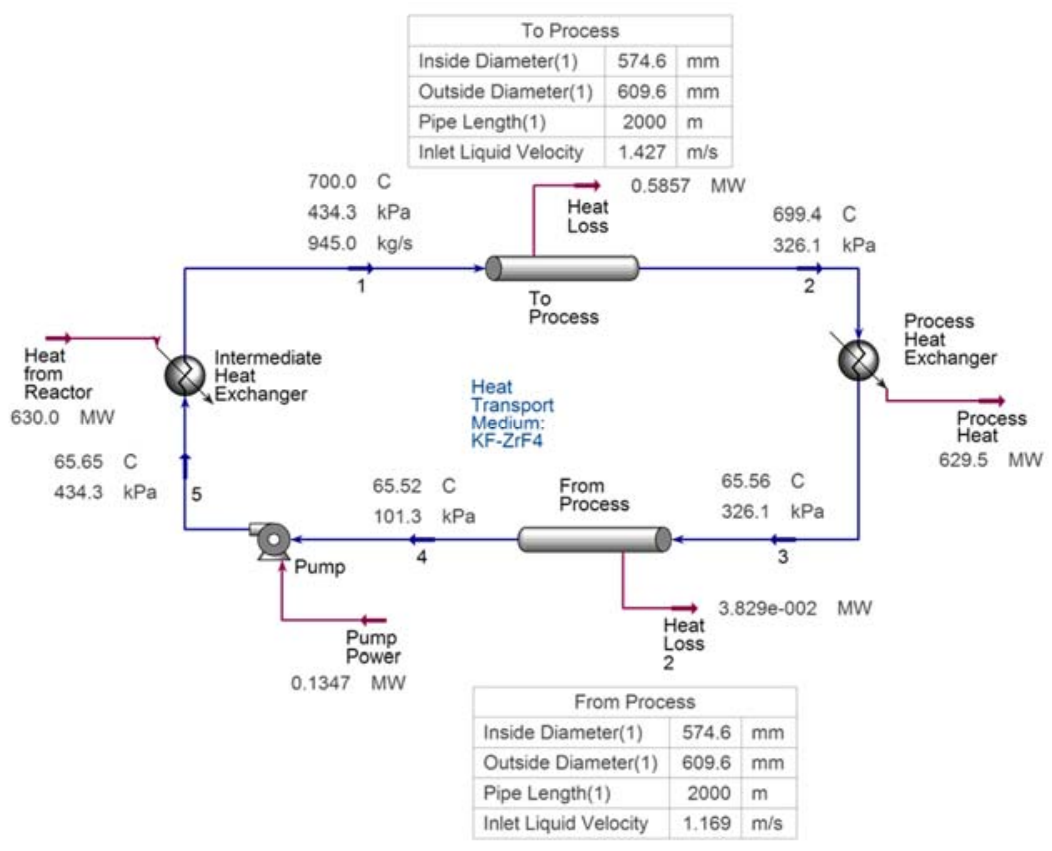

Figure 23. Operating conditions and performance of a 2-km molten-salt circulation loop 


\subsubsection{Clustering Opportunities (Industrial Parks)}

The preponderance of the scale and location of the industrial manufacturing market suggests that one heat source - either an SMR or SIPH - may be practical for a cluster of industries, or an EP where a set of industries is serviced by a large central multi-energy (ME) heat source (e.g., Kurup and Turchi 2015). The Electrical Power Research Institute (EPRI) studied EP and ME concepts over a decade ago to understand how specific electrical, mechanical, and thermal energy currency - both individually and in combination - can be derived from a menu of distributed generation resources options (EPRI 2003). The basic example of a ME system is a CHP application with an integrated energy-management control scheme to optimally balance heat production with electricity demands.

The EPRI reports points out that "A key step in identifying the requirements for a ME-based system is to evaluate the energy needs of the loads to be served." The larger diversity of loads present in an EP can possibly help to simplify the application of suitable generation systems by allowing improved load factors for both thermal and electrical loads.

An ME concept that is gaining some interest is N-R HES. A report on the economic potential of N-R HES concludes that the systems would be economically feasible if capacity payments are adequate and the systems mainly provide thermal energy to industry or an EP while also dispatching electricity to the grid to support power-generation resources adequacy (Ruth et al. 2016a).

\subsection{Heat Recuperation}

Modern chemical plants optimize heat integration to achieve the highest thermodynamic efficiency possible on a cost-benefit basis. Such principles make it possible to use a lower-grade heat source to preheat the reactants entering a process, followed by heat exchange with hot products leaving the reactor. Then the final heat-up to reacting conditions can be achieved and maintained by a topping-heat cycle. An example of this concept is high-temperature steam electrolysis.

High-temperature steam electrolysis achieves the optimal thermodynamic efficiency around $850^{\circ} \mathrm{C}$. Intermediate-temperature/pressure steam entering the process can be generated by a LWR or SIPH that delivers saturated steam to the process. Figure 24 plots the enthalpy of states of steam that was first heated by low-temperature heat recuperation, followed by heating and vapor superheating accomplished with a secondary heat loop associated with a LWR or SIPH. High-temperature heat recuperation is restricted only by the minimum approach temperature of the heat exchanger, which is generally limited to $10-15^{\circ} \mathrm{C}$ to optimize heat-exchanger costs versus heat-transfer efficiency (Sabharwall 2011). The minimum approach temperature is the minimum temperature difference between the hot and cold side of a heat exchanger. The final heat-up is completed with a topping heater. In the illustration, electrical heating is used because it is cost effective for the relatively small amount of heating that is needed for this case. 


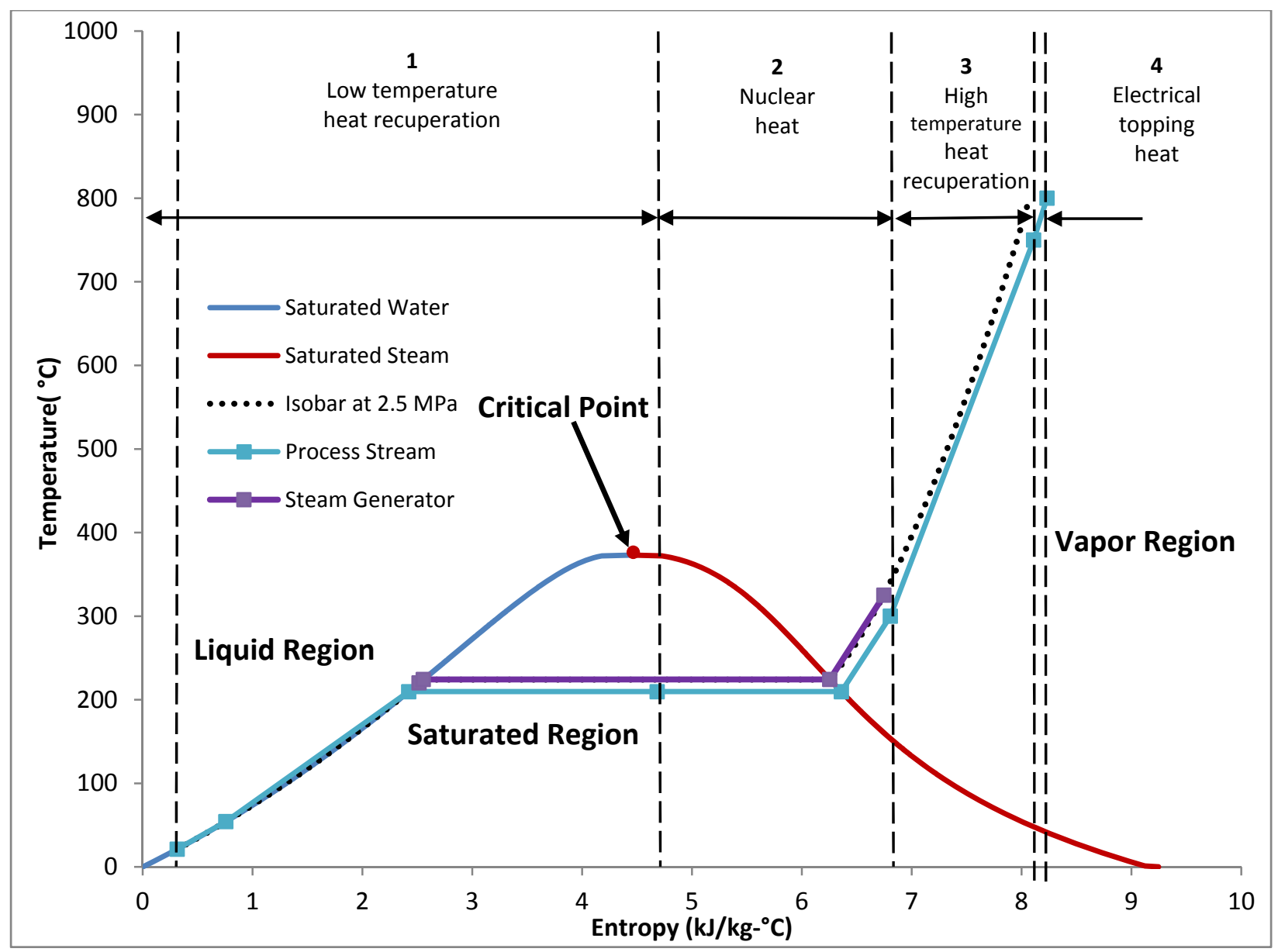

Figure 24. Steam heat-up for high-temperature steam electrolysis

Steam generation through heat recovery is commonly performed with a heat recovery steam generator, where tail gases are often burned to reduce pollutant emissions, while generating steam for CHP purposes. This concept is also an option for raising the temperature of $300^{\circ} \mathrm{C}$ steam provided by an SMR or SIPH, which then can be used in processes that require higherquality steam. Oil refineries and chemical synthesis plants are examples where this concept may reduce fossil-fired heaters that currently operate on natural gas.

McKellar (2011) compared a variety of heat-transfer fluids for the transport of heat from an HTGR to generate steam for oil sand production sites. The study compared steam, carbon dioxide, helium, FLiNaK, and Dowtherm with the distance of 25 kilometers between the well pads and the reactor. In this case, the heat-transport pipeline was constructed from 24 -inch, Schedule 160 pipe, with a 6-inch casing of Aerogel insulation. The temperature of the steam was limited to $550^{\circ} \mathrm{C}$ to prevent pipeline damage. The temperature of Dowtherm was limited to $405^{\circ} \mathrm{C}$ (which is likely the high end of operation for this organic fluid). The quality of steam generated at the well head was $310^{\circ} \mathrm{C} / 10 \mathrm{MPa}$. In this case, FLiNaK and steam exhibited the best comparative technical performance within the analysis. Although FLiNaK performed well, the mass required to be used by the delivery and return lines is more the twice the other heat-transfer fluids. The main conclusion of the analysis was that steam was the best heat transfer fluid for this 
application because of low pumping costs, low cost and readily accessible fluid, and ability to transport heat duty on the order of liquids and salts.

\subsection{Chemical Heat Pumps and Heat Transport}

Chemical heat pumps can serve two technical purposes: first, to amplify the temperature of a thermal hydraulic fluid, and second, to transport energy that is converted into heat at the point of heat use. In the latter case, heat transport over longer distances is accomplished simply through the transport of chemically bound energy. In both cases, the heat source involves an endothermic reaction that absorbs heat to create a transportable product that releases its heat through a reversible reaction. The most attractive transport systems could be defined with the following conditions (Kugeler et al. 1975):

- The chemical reaction needs to be reversible.

- The reaction enthalpies should be as high as possible so that the transported product has a high energy density.

- The forward and backward reactions need to have favorable temperatures.

- The catalysts needed for the reactions should be readily available and low cost.

- Toxic or corrosive substances should be avoided.

- The reactants and products utilized should be readily available.

The advantage of chemical heat pumps is that no heat is lost along the pipeline because the fluid is not heated, but transported at ambient temperatures. Reactions under consideration include the reforming of methane with steam or carbon dioxide, the dissociation of ammonia, and other chemical catalytic reversible reactions.

An example of a chemical heat pump is methane reforming and re-methanation. Methane reforming with steam is an overall endothermic reaction:

$$
\begin{aligned}
& \mathrm{CH}_{4}+\mathrm{H}_{2} \mathrm{O}(\mathrm{l}) \leftrightarrow \mathrm{CO}+3 \mathrm{H}_{2}, \Delta \mathrm{H}_{298 \mathrm{~K}}=250 \mathrm{~kJ} / \mathrm{mol}\left(\mathrm{CH}_{4}\right) \\
& \mathrm{CO}+\mathrm{H}_{2} \mathrm{O}(\mathrm{l}) \leftrightarrow \mathrm{CO}_{2}+\mathrm{H}_{2}, \Delta \mathrm{H}_{298 \mathrm{~K}}=-41.2 \mathrm{~kJ} / \mathrm{mol}(\mathrm{CO})
\end{aligned}
$$

The methanation reaction is exothermic:

$$
\mathrm{CO}+3 \mathrm{H}_{2} \leftrightarrow \mathrm{CH}_{4}+\mathrm{H}_{2} \mathrm{O}(\mathrm{l}), \Delta \mathrm{H}_{298 \mathrm{~K}}=-250 \mathrm{~kJ} / \mathrm{mol}\left(\mathrm{CH}_{4}\right)
$$

In this chemical loop, the source heat (nuclear reactor or SIPH) is used to produce synthetic gasoline, which is transported to the industrial process where the synthetic gasoline goes through a methanation process to release the heat. The methane returns to the heat source. A $950^{\circ} \mathrm{C}$ HTGR can provide ultra-high-pressure steam qualities at the user site (Kugeler et al. 1975; Ma et al. 2009; Fedder and Hoehlein 1982).

Sorption processes may also be used to transport low-grade heat over long distances. For example, ammonia-water absorption cycles have been shown to provide both heat and cooling at user sites using waste heat at the source. The coefficient of performance (heating or cooling 
divided by power input) has been shown to be 0.43 to produce chilled water at $8^{\circ} \mathrm{C}$ with an ambient temperature of $35.5^{\circ} \mathrm{C}$; a coefficient of performance of 0.45 can produce heat at $59.2^{\circ} \mathrm{C}$ with an ambient temperature of $9^{\circ} \mathrm{C}$ (Mazet et al. 2010; Lin et al. 2011). Lithium bromide-water systems could also function similarly; however, at least one study has shown that this system may cost more than the ammonia system (Ma et al. 2009).

\subsection{Electrical Heating}

Several forms of electrical heating are employed in the process industries. Electro-heating has several advantages, including clean operations (no emission and effluent problems), constant quality and availability, rapid application, and relative ease of temperature control. Common techniques for electrical heating include resistive heating, induction heating, dielectric heating, and infrared heating. Plasma-torch heating has some niche market applications. Other electrical heating options generally fall under the category of electrochemical processes: electrochemical batteries, electroplating, electro-refining, electrically driven lasers for focused heating and welding applications, and electro-barrier discharge reactors (or cool plasma). Together, these electrical heating options can help electrify the industrial sector.

Resistive heating is generally used to heat a small chemical reactor or a batch process. It requires only some form of resistance to electrical flow to generate heat that is dissipated to the chemical reactor vessel or reaction material in contact with the resistive material. Direct (Ohmic) heating involves passing current through a material to generate in-situ heat. Glass melting is one industrial process that takes advantage of the Ohmic heating of molten glass. Indirect heating simply passes current through an external resistance material and the heat generated is transferred to the reactor by conduction when heating a solid, the external surface of a chemical reactor, or the reactants in chemical reactors when a heating element or coil is used. Hot gases can easily be produced by convection when circulated in a resistively heated heat exchanger. Radiation heat transfer is invoked when a solid needs to be heated in an inert environment using a furnace.

Induction heating is currently used primarily in the metal industry for billet heating prior to forming or for surface-hardening techniques. The main advantages with this technique are rapid heating rates and a uniform heat flux that can be attained by inducing alternative currents in the body or industrial reactor process. The penetration, or depth and rate of heating, depends on the frequency and duration of the applied current. Larger units incorporate flux guides to provide an easy return path for magnetic flux, reducing the stray heating effects within the metal structure and also reducing the required power input. A number of chemical processes can be retrofit to apply induction heating by simply comingling the feed with a separable metal body or several metal bodies, or by installing a fixed electrical conductor in the reactor that functions similar to a steam or hot-gas heating coil.

Dielectric heating can be effective when process reactants are molecules that respond to an electric-field alternating radio frequencies (10-30 megahertz [MHz]) or microwave frequencies (300-3,000 MHz). This technique applies strictly to non-conducting materials. The effectiveness of dielectric heating depends on the structure of the molecules subject to the effects of the applied electric field. Microwave heating is widely used in the food industry. The Federal Communications Commission (FCC) and the Food and Drug Administration (FDA) have 
approved two frequencies of microwaves for application to foods: $896 \mathrm{MHz}$ and 2,450 MHz. For industrial-scale use, this microwave heating is mainly for drying applications. Radio-frequency heating is also common in the food industry, at FCC- and FDA-approved frequencies of 13.56, $27.12,84.0$, and $168 \mathrm{MHz}$. Both microwave and radio-frequency heating have been developed for coal and biomass drying (FDA 2015).

Energy penetration is more effective at microwave frequencies. Two types of microwave frequencies are authorized for industrial use in heating applications: serpentine applications (heating sheet materials with zig-zag path to introduce multiplicity of passes leading to high efficiency of energy usage and uniform heating) and multimode applicator (as used in domestic microwave ovens). Three types of radio-frequency applicators are commonly used: heating platen, stray-field electrode technique, and staggered-through-field system. Radio-frequency applicators contain an electrode system that, together with the material or product, forms a tuned circuit coupled indirectly to the generator output. The application selection determines the suitable process of radio and microwave frequency heating technique.

Infrared heating is common throughout industry. Hot resistance heaters emit radiation using emitters that operate above $2,000^{\circ} \mathrm{C}$ (Hewitt et. al. 1994). The main advantages of infrared heating are high rates of heat transfer, low heat losses (reduced capital on insulation required), and the elimination of potential contamination from fuel combustion. Infrared heating is best applied for flat surfaces or regular shapes, in general. The work piece or solid material must be in direct line of sight with the emitter, and large heating requirements or high process-throughput rates may be difficult to achieve.

Electric-arc process heating is accomplished when an arc is struck either between two electrodes or between one electrode and the chemical-reactor charge, which is generally a metal solid. When an air gap is subjected to very high voltage, electrostatic forces ionize the air in the gap. Ionized air behaves like a conductor, so the current starts flowing through the ionized gap, in the form of a continuous arc. The temperature of the arc may reach very high temperatures, between $3,000^{\circ} \mathrm{C}$ and $3,500^{\circ} \mathrm{C}$, sufficient to melt any known metal. Appendix D shows that graphite electrodes are used to achieve high heat rates at temperatures around $2,200^{\circ} \mathrm{C}$.

\subsection{Thermal and Electro-Thermal Energy Storage}

Thermal and electrical energy storage technologies can be used to balance the mismatch between energy production and use by industry. The type and scale of thermal energy storage depends on the quality of heat required by the process, the demand profile of the process-unit operations (i.e., batch or continuous), and the economics of heat production and storage. Thermal energy storage systems include traditional steam accumulators, solid- or liquid-state materials with high heat capacities, and phase-change materials that exploit the relatively high energy involved in melting or freezing of a material. The goal is to store thermal energy whenever there is excess energy-generation capacity in the supply system - including excess electrical power generation potential on the grid. The stored energy is subsequently recovered when demand exceeds the capacity of energy-generation resources.

The basic principle behind steam accumulators is to inject steam into an insulated, pressurized accumulator tank when the demand for process steam is low. When the demand increases again, the steam is flashed and released for process heating, power generation, or CHP. 
Brick, metals, and salt mixtures can theoretically be heated to any temperature that can be contained by the storage system, including beyond the melting temperature of the material if the system is designed to handle cyclic phase-changing. Heating can be accomplished by resistive, inductive, or convective methods. The cost of heat deposition, reservoir insulation, and operating and maintenance costs need be factored into the value proposition of the heat-storage system.

One concept referred to as Firebrick Resistance-Heated Energy Storage (FIRES) consists of an electrically heated firebrick stack (Forsberg 2015). Thermal energy is recovered from the brick stack by means of flowing air over the bricks, or flashing water and superheating the saturated steam using channels or tubes running through the bricks in some fashion to extract the heat from the thermal mass. Heat-circulation systems that are being developed for SMRs and SIPH are especially viable. Heat-storage reservoirs based on the CSP salts featured in Table 14 have already been developed and applied commercially in the United States and worldwide. The advantage of these heat reservoirs is the ability to circulate the molten salt to the process on demand. Liquid reservoirs can incorporate a closed-circuit heating coil linked to the heat source, and a separate coil—closed or open circuit—linked to the process. In practice, one to several heat-circulation coils can be used to service plant thermal-heating needs, or even to service a cluster of energy consumers.

\subsection{Hybridization}

Hybrid energy systems (HES) have been proposed as a solution to using the excess power generation capacity that exists on the electrical grid when the generation capacity exceeds demand periods. In the context of the national energy systems, the definition of a hybrid system is one that dynamically uses heat or electricity to optimize the financial efficiency of the systems by the producing the highest value set of energy services and products throughout the year. These products include electricity, manufactured goods, and intermediate energy carriers that may be stored or directly used to produce the set of products. The value proposition of "greenfield" hybrid energy systems concept is currently being address by DOE, with an emphasis on regional scenarios that include a relative high, hypothetical, penetration of renewable energy (Bragg-Sitton 2016; Ruth et al. 2016a). A "brownfield" hybrid energy system at an industrial site would involve the addition of a thermal energy generation source that is dynamically connected to the grid. Three scenarios presented by Ruth et al. (2016b) provide a general view of the basic system integration possibilities for clean thermal energy and power generation.

An HES differs from a co-generation system to the extent that the system maneuvers energy to optimize energy services based on the time-dependent value of these services. By comparison co-generation systems are typically optimized to produce services at a constant rate or according to a schedule of service demands. CHP systems are designed to produce heat (usually steam) and electrical power to cover plant demands. Excess electricity produced by CHP systems is typically dispatched to the grid on a fixed schedule, although the amount of electricity sent to the grid may also be increased when the value can justify throttling or even idling the manufacturing plant (i.e., hybrid operation).

\footnotetext{
${ }^{\mathrm{w}}$ A greenfield plant entails a capital investment for a new project, and all related permitting, new site preparation, construction, and start-up costs. A brownfield plant generally involves either a retrofit, or a additional capital investment at an existing site and may involve a revision in plant operating permits.
} 
The analysis by Ruth et al. (2016b) reveals that clean energy sources may economically displace with industry fossil-fired heat generation under the assumptions considered; however, the value position of hybrid operations will depend on the value of electricity. The role and cost of energy storage will also drive hybrid system deployment and operation considerations.

HES may connect to industry through energy storage and energy carriers that are produced using the excess power generation sources that are not tightly coupled to industry. Geographical

separation, differences in SMR scales, and industrial operation cycles may be addressed with the production of an intermediate product. Potable water, hydrogen, and other intermediate chemicals such as methanol and ammonia are examples of intermediate products.

Seasonal energy use patterns are an important consideration for HES. For example, agriculture residues may be processed into energy products during or following the summer-to-fall harvest season. This conveniently corresponds to the fall period when electricity demand is at the lowest level for the year. Similarly, ammonia production during the spring could take advantage of the excess electricity generation capacity while producing fertilizers needed for spring and summer agriculture demands. The tradeoff of ammonia and fertilizer plant capacity factors and product storage associated with constant generation throughout the year should be taken into consideration in such cases.

\subsection{Hydrogen}

Hydrogen production was not identified from our analysis of GHGRP data as a major industrial emitter, but it is directly tied to oil refineries, ammonia production, and chemicals synthesis. As a clean energy fuel, hydrogen production and utilization could be increased. For example, hydrogen could be produced and stored for power generation in stationary fuel cells or for motive fuel in fuel-cell vehicles. Hydrogen production could be used to take advantage of the excess electricity generation capacity that often exists on an hourly, daily, and weekly basis. Hydrogen could be produced on a scale equivalent to the generation capacity of the grid when demand for electricity drops in the spring and fall. This could increase the utilization efficiency of the capital investment associated with both nuclear and renewable energy.

According to recent estimates, about 10 million tonnes of feedstock hydrogen are produced and consumed in the United States each year (EIA, 2008). The analysis for this report indicates refineries consume about $50 \%$ or 5 million tonnes of this inventory for heavy oil hydrocracking and hydrotreating and for desulfurization of sour crude. The remaining share is produced and used for ammonia, methanol and other alcohol production, the food industry, metals refining, glass production, and electronics fabrication. A relatively small amount of hydrogen is currently used for fuel cells, either for material-handling forklifts or light-duty vehicles. This may change with greater penetration of fuel-cell vehicles and availability of hydrogen refueling stations. Additionally, increased production of hydrogen may provide the impetus for utility-scale power production using solid-oxide fuel cells (DOE 2015h) and hydrogen gas-combustion turbines (GE 2010).

Potential new industrial usage of hydrogen (and oxygen) could include:

- Small ammonia plants that are coupled to distributed hydrogen generation 
- On-site production in petroleum refineries and for comparatively small biofuel plants

- Hydrogenation of $\mathrm{CO}_{2}$ in chemicals and fuels synthesis

- Direct reduction of iron ore for clean iron and steel manufacturing

- Hydrogen combustion for heat and reducing atmospheres in glass and steel production

- Hydrogen-enriched flames for process heating and for combustion turbines.

Both domestic and worldwide need for hydrogen could rise if nascent markets are realized for energy crops to produce biofuels and biopower. Additionally, new ammonia uses are on the rise, including use for nitrogen oxide selective catalytic reduction in coal and natural gas power plants and for diesel exhaust fluids that are now required for heavy-duty trucks and mining vehicles.

This report especially notes the high quantity of hydrogen used by the refinery industry (Appendix C). Refineries use hydrogen to hydrocrack heavy-vacuum residuals and oils, to hydrotreat heavy-gasoline distillates, to isomerize light-hydrocarbon fractions, and for crude desulfurization and denitrogenation when necessary to meet fuel specifications. About onefourth of the requisite hydrogen is generated within the refinery in the reformer; the remainder is supplied from an external supplier, usually a natural gas reforming plant. In some areas, such as along the Gulf Coast, a hydrogen pipeline supplies merchant hydrogen to the refineries.

The advent of clean zero-carbon hydrogen would reduce the carbon emissions from refineries. Additionally, refinery plant emissions could be reduced by burning hydrogen in the numerous fired heaters and gas-vent flares throughout refineries, the majority of which are not equipped with pollutant controls given their size and intermittent operation.

Hydrogen production could also be used directly in the steel-making process to 1) reduce iron ore to "sponge" or "pig" iron, 2) purify the iron metal or cast-iron products, and 3) temper or anneal iron and steel products. Direct reduction of iron with hydrogen is a concept that has been proven to be technically feasible (Sohn 2007; Pinegar et al. 2011).

Biofuels production could also become a major consumer of hydrogen. Efficient conversion of biomass resources into synthetic liquid fuels requires distributed processing of the biomass feedstock into a refinery-compatible bio-oil (Jones 2009).

Finally, hydrogen, and oxygen that is co-produced when electrolyzing water can be used to enhance combustion throughout the industrial sector. Hydrogen-enriched natural gas is already going forward in Europe (Shahryar et al. 2014), and interest in the United States is growing with the understanding that hydrogen can be mixed and burned with natural gas by industry. This could reduce industry pollutant emissions without making significant changes to fired heaters and steam boilers.

Based on the data presented in Table 14, petroleum refineries use 9,130 tonnes/day of hydrogen. If hydrogen were used for the iron and steel mills instead of coke, 6690 tonnes/day of hydrogen would be needed. Assuming a $150 \mathrm{MWt}$ light water reactor unit dedicated to producing hydrogen using high temperature steam electrolysis, 309 SMR units would be required for the refineries and 226 SMR units would be used within the iron and steel mills. 


\section{ANAYLYSIS OPPORTUNITIES}

This study highlights the GHG emissions associated with heat demands from the most significant industrial emitters and discusses in detail possible substitute clean heat sources such as nuclear reactors and SIPH. Geothermal heat sources - especially enhanced geothermal sources - also show large potential for heat application, but face barriers of technology maturity and geographical separation of current and prospective geothermal sources from current industrial centers. In many cases, the clean energy sources could replace CHP systems. Some of these systems could operate in a hybrid manner as explained in this report and previous related reports.

Replacement of dedicated power-generation plants, fossil-fired steam boilers, and fired heaters with new steam and hot-gas production systems is possible throughout each of the target industries. The study also finds that direct electrical heating of heat-transfer fluids may also be an effective mode of transferring isolated or remote clean-power generation sources, and/or overgeneration capacity to industry for process heating.

Thermal energy storage may be essential for application of SIPH or to manage variations and differences in grid electricity, industrial thermal energy profiles and scales of production, and industry heat-use needs. Thermal energy storage can be matched to the thermal energy requirements of the industrial user, through temperature boosting and using salt mixtures tailored to liquid-solid fusion temperatures sufficiently above the process operating temperature to deliver a constant heat flux.

Finally, hydrogen use by industry provides another route for imparting clean energy generation sources to industry. Hydrogen can be produced from clean energy sources and then stored on a small or large scale. It can directly replace a large fraction of natural gas and combustion of other carbon-bearing fuels. Hydrogen production from clean energy sources can take up excess energy on a large-scale, thus supplanting traditional steam-methane reforming plants that generate GHG emissions. Large-scale storage is likely a key to providing a consistent source of hydrogen throughout the year.

The above findings and other observations found in this report give rise to the following list of analysis opportunities and technology development and testing.

1. Complete a detailed cost comparison and technical assessment of the potential for heat delivery from SMR, SIPH, and geothermal resources, respectively, with fossil fuels combustion. This analysis could include an analysis of resource availability and siting issues. It could also include an assessment of the annual cost-benefit and potential GHG emissions reductions of SMR, SIPH, and geothermal heat applications versus grid electricity to thermal energy conversion and storage, considering projected grid profiles and the industrial heat-use patterns highlighted in this report. This analysis may provide guidance on matching SMRs, SIPH, and geothermal plants to the various scales of industrial heat users - for example, heat classification of total thermal energy demand less than 1-10 MW, 10-100 MW-thermal, and greater than $100 \mathrm{MW}$. The practical temperature limits for SIPH and enhanced geothermal energy systems will govern the penetration of these heat sources. 
2. Complete case-specific heat application design studies to evaluate heat integration using engineered designs that provide a basis for capital and operating cost expenses to be evaluated. This activity will help establish the business case for some realistic cases and possibly will provide greater impetus for commercial pull. The effort would likely be most effective with industry collaboration to help identify the leading deployment opportunities.

3. Conduct heat-transfer tests for representative industry reactor vessels with hot gases, organic heat-transfer fluids, and other heat-transfer media, including energy deposition in existing process reaction vessels and heat exchangers. This effort may include evaluation of new reactor technologies, such as compact heat-exchanger reactors, that could help improve process intensification and efficiency.

4. Given the temperature limitations of SMRs, SIPH, geothermal resources and heattransfer systems, complete a technical evaluation and the cost-benefits of heat-boosting concepts. This activity may consider heat-topping options-e.g., electrical heating, hydrogen combustion, and chemical heat pumps. It may consider heat boosting through electrical heating of solid media, eutectic salts, molten salts, or liquid metals.

5. Evaluate the feasibility of retrofitting existing CHP power turbines with SMR, SIPH, and geothermal heat-supply sources. This activity may also encompass the cost-benefits of maintaining existing reciprocating energy $\mathrm{CHP}$ plants on emergency standby, or for intermittent operation.

6. Determine the scale and cost of thermal energy storage buffers-e.g., steam accumulators, molten-salt heat reservoirs, process-specific/custom-designed eutectic salt or adsorption/desorption energy storage media, and solid heat-storage media. This effort may lead to new or advanced technology concepts for heat storage by electrical heating. Thermal energy storage concepts developed for concentrating solar systems may be applicable to industry thermal energy reservoirs. Other thermal energy concepts have also been recently proposed. In addition to cost considerations, the thermal dynamic properties of the storage systems and the industrial heat-duty requirements and heattransfer physics need to be considered.

7. Complete a study of current versus future opportunities to develop energy parks. This analysis effort may evaluate heat-distribution costs as a function of distance to plant. It may also evaluate the cost-benefits of economies of scale for SMRs, SIPH, and geothermal options. A variety of manufacturing centers (or energy clusters) may already be suitable for a notional energy park. Future industry replacements or new growth may embrace energy parks surrounding renewable and nuclear energy that may have relatively low operating costs.

8. Evaluate the techno-economic feasibility of potential industry operations that may be best served in hybrid energy systems. Unit operations that may optimize year-round, online operating capacity of SMRs, SIPH, and geothermal systems may include the following industrial plants: 
a. Food processing and/or dehydration, and packaging

b. Conversion of seasonal biomass to intermediate or final products, including biomass drying and stabilization, pyrolysis oil production and stabilization, and increased ethanol production

c. Industry waste-water cleanup or brackish-water desalination and storage

d. Hydrogen generation and storage

e. Intermediate chemical commodities, including synthetic natural gas, methanol, ethylene, ammonia

f. Pumped hydro and compressed-air storage.

Including seasonal energy-use patterns would improve this analysis. In addition, energydelivery reliability, capital-use optimization, and overall system cost-benefits may be evaluated.

9. Evaluate relative cost-benefit tradeoffs of electrification of industry. This study could illustrate the spatial availability and energy concentration of renewable energy sources (wind, solar, geothermal, and marine hydrokinetic energy) and compare it to the nation's manufacturing centers. It is motivated by the location of U.S. manufacturing plants (distributed mainly throughout the Eastern States region to the Upper Midwest, and stretching down to the Gulf Shores) as compared to the best-class wind, solar concentrating, and geothermal resources which are located at the edge of the Midwest, the Southwest, and the Intermountain and coastal mountain areas, respectively. Electrification/electrical heating can ameliorate the geographic separation of renewable and industry. Interest in electrochemical and electrocatalysis processes is also on the rise, as referenced in this report, to produce not just inorganic chemicals such as chlorine and alkalies, but also basic organic compounds. An additional aspect of the analysis is heat deposition by electromagnetic heat transfer because it is pertinent to process intensification.

Moreover, this report reveals that $75 \%$ of industry GHG emissions originate outside of the identified target industries' 960 large-emitting plants. Most of these emissions come from small manufacturing plants whose annual emissions are less than 25,000 tonnes $\mathrm{CO}_{2}$ e. While small-scale thermal energy systems provided by SIPH or geothermal systems may apply to these plants, electrification could be more cost effective.

10. Perform a techno-economic assessment of hydrogen production for supply to industry and the transportation sector, and compare hydrogen production and storage on a large scale considering seasonal power-demand profiles. The potential merits of hydrogen as an energy storage and substitute for fossil-fired heating operations, petroleum and biofuels production, and use as a reductant in metals manufacturing infer that a national-scale hydrogen production system can help optimize the capital operating efficiency of nuclear and renewable power generation. The value of hydrogen and other 
chemicals (e.g., $\mathrm{CH}_{4}$ ) production relative to power production may be included in this assessment.

11. Evaluate the cost and benefits of repurposing biomass waste residuals for transportation fuels production or high-temperature reaction processes such as cement, lime, and steel making. For example, alternative process operations to convert black liquor into transportation fuels or commodity chemicals - with provisions to recover soda ash — could be considered.

\section{Evaluate the impact on U.S. economic competitiveness in terms of supply-chain} industry and workforce needs to implement the mass use of clean energy sources. For perspective, replacement of $10 \mathrm{EJ}$ (9.5 quads) of industry energy (or just one-third of the current annual energy demand by industry, and one-fourth of projected industry energy demand of 39.5 EJ [37.4 quads] in 2025) requires over two-hundred 150-MW (thermal) class SMRs (viz., 235 reactors with 0.9 online operating capacity). Reshoring could require a supply chain of high-purity metals and metal alloys, metal materials production, pressure vessel and pipe manufacturing, instruments and controls supply, and all manner of related plant construction and permanent operator positions. It could also require an expanded nuclear fuels market and solar-reflector commercial manufacturing and installation. It is noteworthy that the demonstrated strength of U.S. manufacturers in the post-recession years in terms of output growth, competitiveness relative to other U.S. economic sectors, productivity growth, and expansion of U.S. multi-national corporations (Moran and Oldenski 2014) could lead to reshoring manufacturing production and an overall expansion of domestic manufacturing. Recent federal efforts, such as the NNMI Program (AMNPO 2015) and the U.S. DOE's CEMI (DOE 2015f), have aimed at further increasing the strength of domestic manufacturing. 


\section{CONCLUSIONS}

This report provides a complement to analysis of process-efficiency improvement by considering how clean energy delivery and use by industry could significantly reduce GHG emissions. It specifically considers the possibility of replacing fossil-fuel combustion in industry with nuclear, SIPH, and geothermal energy sources. The possibility of applying electrical heating and greater use of hydrogen is also considered. This work is unique and points to the need for further analysis. If the hypotheses and concepts are correct, then U.S. industrial competitiveness in a carbon-constrained economy may be enhanced by accelerating technology readiness in the areas highlighted in this report.

The EIA projects that total U.S. energy consumption will grow to about 108 EJ (102 quads) in 2025, with nearly all of the growth coming from the industrial sector (DOE 2015g). Annual energy consumption in the industrial sector is forecast to increase to $39.5 \mathrm{EJ}$ (37.4 quads) - a $22 \%$ increase, exceeding $36 \%$ of total energy consumption in the United States.

The industrial sector was the third-largest source of direct U.S. GHG emissions in 2014, behind electricity generation and transportation, accounting for roughly $20 \%$ of total emissions (EPA 2016). Fuel combustion results in about $58 \%$ of U.S. industrial direct GHG emissions and is largely driven by the demand for process heating, process reactions, and process evaporation, concentration, and drying. As a result, mitigating industrial direct GHG emissions will involve changes to how heat demands are met.

This report assimilates EPA GHGRP-reported emissions data and GHG emissions factors to calculate thermal energy demands at a resolution not previously available to the public. Fourteen key industries, comprising 960 facilities ( $0.33 \%$ of all U.S. manufacturing facilities), with the relatively highest annual GHG emissions were selected for assessment of their emission characteristics and thermal heat duties. The calculated combustion energy use in 2014 by these industries was 5,824 PJ (5.5 quads) - equivalent to nearly 50\% of combustion energy in 2010 reported by EIA MECS and 5\% of U.S. total GHG emissions in 2014.

The thermodynamic nature, scale, and heat-use patterns of representative facilities were evaluated for each target industry. The common feature of these industries is they convert raw materials into energy services by means of physical and chemical changes. These changes generally require thermal energy to affect solids and liquids heat-up, melting, and evaporation, and to heat up reactants to initiate molecular bond breaking and to sustain the propagation of chemical reactions. Heat demands range from low-temperature steam $\left(50^{\circ} \mathrm{C}, 0.7 \mathrm{MPa}\right)$ used for steeping in corn wet milling up to high-temperature-unit operations (up to $1,500^{\circ} \mathrm{C}$ ) used for heating cement kilns. The scale of heat demand for the average facility ranges from a heat input of $1.76 \mathrm{TJ}$ per day (1,700 MMBtu/day; or $21 \mathrm{MW})$ for production of 11,000 bpd ethyl alcohol to $26 \mathrm{TJ} /$ day $(25,000 \mathrm{MMBtu}$; or $300 \mathrm{MW})$ for roughly 5,000 tonnes per day of potash, soda, or borate mining and processing. Discussion of additional technical characteristics and considerations is provided in the main body of the report and the appendices.

The practical limit of clean heat sources depends on the temperature output of the source. Current high temperature gas-cooled SMRs can provide upwards of $850^{\circ} \mathrm{C}$, and with materials development, $950^{\circ} \mathrm{C}$ may be attainable with demonstration of metal alloys performance at these 
temperatures. For industrial heat duties above these temperature thresholds - such as required for cement mineral calcination, it may be necessary to substitute fuels derived from biomass, including biomass char or synthetic natural gas produced from biomass, to supplant the fossil fuels that are currently combusted to achieve temperatures approaching $1,500^{\circ} \mathrm{C}$.

Substitution of one-third of the projected 2025 industrial energy demand could be met by about 235 SMRs with a capacity rating of $150 \mathrm{MW}$ forecast. This study indicates the scale of the largest industrial energy users is amenable to the scale of SMR applications. SIPH and geothermal energy could readily supply future industrial heat demand; however, the best solar insolation and identified geothermal sites are distant from most of the current industrial centers.

Further analysis is warranted to identify and quantify opportunities for conversion of industrial thermal energy requirements to clean energy. Some of those analyses are listed in the previous section on Analysis Opportunities.

Several technical challenges and opportunities to application of clean energy sources for industrial heat users were identified and are discussed in this report, including:

- Quality of heat required by the user (or temperature of the working fluid)

- Industry process heat-transfer modes

- Scale of heat source versus heat user demand which may be mitigated by selecting the appropriate source or by industrial clustering (also referred to as an energy park)

- Transport requirements between the heat source and industrial process-unit operations which involves distance and the materials needed for that transport

- Thermal energy storage needs and options

- Hybrid heat/electricity production

The following list is an abbreviated recapitalization of the report observations and finding:

1. Fourteen industries were selected for process-level thermal analysis. In 2014, 960 plants representing these industries reported emissions under the GHGRP. They constitute less than $0.5 \%$ of all U.S. manufacturing facilities, but are responsible for nearly $25 \%$ of U.S. GHG inventory industrial-sector emissions, which equates to $5 \%$ of U.S. total emissions in 2014. Most of the remaining 75\% of industrial GHG emissions is therefore tied to smaller facilities that fall under the EPA reporting limits for large GHG emitters.

2. Calculated combustion energy use in 2014 by the 14 target industries was 5,824 petajoules $\left(1 \mathrm{PJ}=10^{15} \mathrm{~J}\right)$ or 5.520 quads - nearly $50 \%$ of 2010 manufacturing combustion energy use estimated by the EIA Manufacturing Energy Consumption Survey (MECS).

3. Within those 14 industries, CHP and conventional steam boilers account for about $70 \%$ of the heat loads. Those and other fossil-fired heating systems could be substituted by 
clean heat sources generating steam, hot gas, and heating other heat-transfer media. Options for clean heat sources include emerging SMRs, SIPH, and geothermal sources, as their scales are applicable to individual industry needs.

4. Most process heating within these 14 industries is accomplished with steam jackets, heating coils, and indirect heat exchangers that transfer heat from a hot gas (generally combustion gases) to the process reactor. Clean heating systems could replace the combustion gas systems by using heat circulation systems such as those described in this report.

5. Several industrial heat users, such as oil refineries, pulp/paper manufacturing, methanol, fertilizer plants, corn wet milling plants, and some inorganic mineral plants, have duties in excess of $10 \mathrm{TJ} /$ day $(9,500 \mathrm{MMBtu} ; 120 \mathrm{MWt})$. SMR technologies are expected to be well-matched to this scale of demand.

6. SIPH applications can potentially supply heat to the majority of the industrial applications analyzed here. Specific examples include chlorine/alkali plants, ethylene and other chemical production plants, and food processing plants. Currently, all of the major concentrating solar projects in the U.S. are in the Southwest, with a few in Florida and Hawaii. Therefore, SIPH systems for industrial heating are likely to be impacted by the effectiveness of insolation at the location of the industry. Additionally, the footprint of available space for concentrating solar energy systems and energy storage systems are other technical considerations.

7. Geothermal energy could provide thermal energy to food processing plants and to plants that use lower temperature heat to concentrate and/or dry process feedstocks and products. Corn milling and drying and ethyl alcohol production are two examples. Current geothermal energy production techniques usually provide lower temperature energy (typically ranging from $50-150^{\circ} \mathrm{C}$ ) than is required by industry. Enhanced geothermal systems that could achieve higher temperature output are currently being developed.

8. The design of heat transport from SMR and SIPH sources to the industrial user may be optimized with a heat circulation system that uses a liquid heat transfer media— such as a molten salt or Dowtherm ${ }^{\mathrm{TM}}$ — to deliver thermal energy over relatively long distances. Heat transfer to a hot gas or steam loop may then optimally interface with the heating coils or boiler tubes that are used in most industrial processes.

9. Heat recuperation and temperature boosting are important thermal energy management concepts that may benefit SMR, SIPH, and geothermal energy sources. High temperature heat pump concepts, including adsorption/desorption chemical cycles, can help boost the temperature of heating media.

10. Hybrid thermal/electricity generation may help balance hourly, daily, and/or seasonal electrical cycles. Seasonal heat load opportunities include food processing and/or dehydration, conversion of biomass to intermediate products by drying, torrefaction, pyrolysis oil production and stabilization, ethanol production, hydrogen production, 
industry waste-water cleanup or brackish-water desalination, and pumped hydro and compressed-air storage.

11. Intermittent or batch plant operations may require thermal energy storage systems that match clean energy delivery with thermal load schedules.

12. Electrification of industry warrants further consideration. Thermal energy storage concepts such as those being developed for concentrating solar systems may help coordinate grid profiles with industry heat use profiles. Direct electrical heating is technically feasible, but could add to grid response dynamics and challenges.

13. Hydrogen production for use as a substitute fuel gas by industry could reduce industry GHG emissions. Hydrogen can also replace carbon that is used as a reducing agent in steel manufacturing. Hydrogen that is produced by water splitting would provide carbonfree hydrogen for these uses.

14. This report identified opportunities to use approximately $403,150-\mathrm{MW}_{\mathrm{t}}$, nuclear reactor modules, supplying $1,900 \mathrm{PJ} / \mathrm{yr}$ of heat ranging up to $850^{\circ} \mathrm{C}$. Petroleum refineries use 9,130 metric tonnes/day of hydrogen. Substitution of hydrogen for coke in the U.S. steel production would use an additional 6,690 metric tonnes/day of hydrogen. This could be provided by high temperature steam electrolysis plants that use electricity and heat supplied by one of the clean energy sources. Assuming light-water SMR units with a 150 MWt capacity are used, 309 SMR modules would be necessary to produce all of the refinery merchant hydrogen demand and 226 SMR modules would be necessary to produce merchant hydrogen for the steel industry. To supply heat to industry and hydrogen to both refineries and steel production, $939 \mathrm{SMRs}$, rated at $150 \mathrm{MW}_{\mathrm{t}}$, would be necessary. More would be needed if industries with a heat duty under $150 \mathrm{MW}_{\mathrm{t}}$ are located in a cluster. The potential number of SMRs that could be built may be limited to siting restrictions and licensing restrictions.

15. SIPH and geothermal energy systems are theoretically scalable to any load. Commercial systems for SIPH range from $100 \mathrm{~kW}_{\mathrm{t}}$ for small industries to approximately $1,000 \mathrm{MW}_{\mathrm{t}}$ for concentrating solar power (CSP) systems. SIPH could therefore supply up to 2000 $\mathrm{PJ} / \mathrm{yr}$ to the 14 target industries identified in this report before considering practical temperature and spatial constraints. By comparison, geothermal systems that can provide a heat supply media at $150^{\circ} \mathrm{C}$ can provide up to $180 \mathrm{PJ} / \mathrm{yr}$ to those target industries. SIPH and geothermal energy may be impractical in some locations due to resource quality. 


\section{REFERENCES}

Advanced Manufacturing National Program Office (AMNPO). 2015. "National Network for Manufacturing Innovation (NNMI).” Web page accessed July 2016.

https://www.manufacturing.gov/nnmi/.

Augustine, C. 2011. "Updated U.S. Geothermal Supply Characterization and Representation for Market Penetration Model Input.” NREL/TP-6A20-47459, October 2011.

Alvarado, Marc. The changing face of the global methanol industry. June 20, 2016.

http://www.chemweek.com/lab/The-changing-face-of-the-global-methanol-industry_80172.html.

BARC (Bhabha Atomic Research Centre). 2016. "Reactor Technology \& Engineering: Chapter 19. Nuclear Desalination."

http://www.barc.gov.in/publications/eb/golden/reactor/toc/chapter19/19.pdf.

Boardman, R., and R. Cherry. 2014. "A Primer for LWR Heat Applications, White Paper.”

Bolden, Lauren, Piyush Sabharwall, and Chad Painter. 2014. "An Overview of Small Modular Reactors: Status of Global Development, Potential Design Advantages, and Methods for Economic Assessment." International Journal of Energy, Environment, and Economics, Volume 22, Number 5, 437-459.

Botte, G. 2014. "Interface." The Electrochemical Society. Accessed July 22, 2016.

http://www.electrochem.org/dl/interface/fal/fall4/fall4_p049_055.pdf.

Bracmort, K. 2016 “Is Biopower Carbon Neutral?” Congressional Research Service R41603. Accessed September 16, 2016. http://www.fas.org/sgp/crs/misc/R41603.pdf

Bragg-Sitton, S.M., Boardman, R., Rabiti, C., Kim, J.S., Mckellar, M., Sabharwall, P., Chen, J. 2016. Nuclear-Renewable Hybrid Energy Systems 2016 Technology Development Roadmap," INL/EXT-16-38165, March, 2016.

Carelli, Mario D., Daniel T. Ingersoll, 2015. Handbook of Small Modular Nuclear Reactors, Oxford: Elsevier Ltd.

Coleman, J., and P. Sabharwall. 2014. "Seismic Risk Management Solution for Nuclear Power Plants, Federation of American Scientists.” Public Interest Report 67.

Continuous Emission Monitoring. 1993. Code of Federal Regulations. Vol. 40. http://www.ecfr.gov/cgi-bin/text-idx?tpl=/ecfrbrowse/Title40/40cfr75 main_02.tpl.

D\&M Plastics, Inc. 2016. "All About Plastic Moulding: The Rotational Moulding Technique." http://www.plasticmoulding.ca/techniques/rotational_moulding.htm.

Ecofys. 2013. "European Chemistry for Growth: Unlocking a Competitive, Low Carbon and Energy Efficient Future.” Brussels: European Chemical Industry Council (Cefic).

http://www.cefic.org/Documents/PolicyCentre/Reports-and-Brochure/Energy-RoadmapThe\%20Report-European-chemistry-for-growth.pdf. 
Eggeman, Tim. 2010. "Ammonia." In Kirk-Othmer Encyclopedia of Chemical Technology, 133. John Wiley \& Sons, Inc.

Eggeman, Tim. 2010. "Lime and Limestone." In Kirk-Othmer Encyclopedia of Chemical Technology, 1-53. John Wiley \& Sons, Inc.

Eggeman, Tim. "Steel." In Kirk-Othmer Encyclopedia of Chemical Technology, 1-78. John Wiley \& Sons, Inc.

Electric Power Research Institute. 2003. "Partial Design of a Multi-Energy Park at Clarkson University: Simulating the Electrical Performance of the Multi-Energy Park." Report number 1002286. Palo Alto, CA. Accessed August 2016.

http://www.epri.com/abstracts/Pages/ProductAbstract.aspx?ProductId=000000000001002286.

Elshennawy, A. K., and G. S. Weheba. 2015. "Chapter 4: Iron and Steel." In Manufacturing Processes and Materials. Society of Manufacturing Engineers.

European Cement Association (CEMBUREAU). 2013. "The Role of Cement in the 2050 Low Carbon Economy." Brussels: CEMBUREAU.

http://lowcarboneconomy.cembureau.eu/uploads/Modules/Documents/cembureau-brochure.pdf.

Fedders, H., and B. Hoehlein. 1982. "Operating a Pilot Plant Circuit for Energy Transport with Hydrogen-Rich Gas.” International Journal of Hydrogen 7, 793-800.

Fischedick, M., J. Roy, A. Abdel-Aziz, A. Acquaye, J.M. Allwood, and J.-P. Ceron. 2014a. "2014: Industry." In Climate Change 2014: Mitigation of Climate Change. Contribution of Working Group III to the Fifth Assessment Report of the Intergovernmental Panel on Climate Change, 739-810. Cambridge, United Kingdom and New York, NY, USA: Cambridge University Press.

Fischedick, M., J. Marzinkowski, P. Winzer, and M. Weigel. 2014b "Techno-Economic Evaluation of Innovative Steel Production Technologies." Journal of Cleaner Production, Special Volume: The Sustainability Agenda of the Minerals and Energy Supply and Demand Network: An Integrative Analysis of Ecological, Ethical, Economic, and Technological Dimensions, 84: 563-80. doi:10.1016/j.jclepro.2014.05.063.

Charles Forsberg. 2015. "Strategies for a Low-Carbon Electricity Grid and Full Use of Nuclear, Wind, and Solar Capacity to Minimize Total Costs," MIT-ANP-TR-162, August, 2015.

Food and Drug Administration (FDA). 2015. "Kinetics of Microbial Inactivation for Alternative Food Processing Technologies -- Microwave and Radio Frequency Processing." Accessed September 7, 2016.

http://www.fda.gov/Food/FoodScienceResearch/SafePracticesforFoodProcesses/ucm100250.htm

Fox, D.B., D. Sutter, and J.W. Tester. 2011. "The Thermal Spectrum of Low-Temperature Energy Use in the United State." Ithaca, NY: Cornell Energy Institute. 
Fridleifsson, I. 1996. “The Role of Geothermal Energy,” Geo-Heat Center, Quarterly GHC Bulletin, August 1996.

Garcia, H., Chen, J., Kim, J. S., McKellar, M. G., Deason, W., Vilim, R., Bragg-Sitton, S. M., Boardman, R. D. 2015 "Nuclear Hybrid Energy Systems - Regional Studies: West Texas \& Northeastern Arizona" INL Report INL/EXT-15-34503 (April 2015).

GE. 2010. "GE Perspectives - Advanced IGCC/Hydrogen Gas Turbine Development." October 2010.

https://www.netl.doe.gov/publications/proceedings/10/utsr/presentations/tuesday/Anderson.pdf.

Geothermal Energy Association. 2016. "2016 Annual U.S. \& Global Geothermal Power Production Report." Accessed September 7, 2016. http://geo-

energy.org/reports/2016/2016\%20Annual\%20US\%20Global\%20Geothermal\%20Power\%20Pro duction.pdf.

Greenblatt, J.B. 2015. "Modeling California Policy Impacts on Greenhouse Gas Emissions." Energy Policy 78 (March): 158-72. doi:10.1016/j.enpol.2014.12.024.

Hewitt, G.H., G.L. Shires, T.R. Bott. 1994. Process Heat Transfer. CRC Press. ISBN 0-84939918-1

Ingersoll, Daniel T. 2015. "Chapter 2: Small modular reactors (SMRs) for producing nuclear energy: international development." In Handbook of Small Modular Nuclear Reactors, by Mario D. Carelli and Daniel T. Ingersoll, 27-60. Oxford: Elsevier Ltd.

Ingersoll, D., Z. Houghton, R. Bromm, C. Desportes, M. McKellar, and R. Boardman. 2014. "Extending Nuclear Energy to Non-Electrical Applications." The $19^{\text {th }}$ Pacific Basin Nuclear Conference, Vancouver, British Columbia, Canada, August 24-28, 2014, (PBNC2014-209).

Intergovernmental Panel on Climate Change. 2014. "Climate Change 2014: Mitigation of Climate Change : Working Group III Contribution to the Fifth Assessment Report of the Intergovernmental Panel on Climate Change." Edited by O. Edenhofer, R. Pichs-Madruga, Y. Sokona, E. Farahani, S. Kadner, K. Seyboth, A. Adler, I. Baum, and S. Brunner. Cambridge University Press.

Jones, S.B. 2009., "Production of Gasoline and Diesel from Biomass via Fast Pyrolysis, Hydrotreating and Hydrocracking: A Design Case," PNNL-18284, February, 2009.

Khalil, Yasmin Pascual. 2015. "Methanol to Gasoline: A Novel Technology Challenged by Low Oil Prices." Web page accessed August 2016.

http://insights.globalspec.com/article/1397/methanol-to-gasoline-a-novel-technology-challengedby-low-oil-prices.

Kugeler, K., H.F. Niessen, M. Roeth-Kamat, D. Boecker, B. Rueter, and K.A. Theis. 1975.

"Transport of Nuclear Heat by Means of Chemical Energy (Nuclear Long-Distance Energy)." Nuclear Engineering and Design 34, 65-72. 
Lin, P., R.Z. Wang, Z.Z. Xia, and Q. Ma. 2011. Ammonia-water Absorption Cycle: A Prospective Way to Transport Low-Grade Heat Energy Over Long Distance.” International Journal of Low-Carbon Technologies Advance Access, 1-9.

Leadership in Nuclear Energy (LINE) Commission. 2016. Web page accessed August 2016. https://line.idaho.gov/.

Locatelli, G., M. Mancini, N. Todeschini. 2013. "Generation IV Nuclear Reactors: Current Status and Future Prospects.” Energy Policy 61, 1503-1520.

Loftus, P.J., A.M. Cohen, J.C.S. Long, and J.D. Jenkins. 2015. “A Critical Review of Global Decarbonization Scenarios: What Do They Tell Us about Feasibility?” Wiley Interdisciplinary Reviews: Climate Change 6 (1): 93-112. doi:10.1002/wcc.324.

Lund, J. 1996. "Direct Heat Utilization of Geothermal Resources," Geo-Heat Center, Quarterly GHC Bulletin, August 1996.

Ma, Q., L. Luo, R.Z. Wang, and G. Sauce. 2009. "A Review on Transportation of Heat Energy Over Long Distance: Exploratory Development." Renewable and Sustainable Energy Reviews $13,1532-1540$.

Mandatory Greenhouse Gas Reporting. 2009. Code of Federal Regulations. Vol. 40. http://www.ecfr.gov/cgi-bin/text-idx?tpl=/ecfrbrowse/Title40/40cfr98 main 02.tpl.

Mazet, N., L. Luo, D. Stitou, and J. Berthiaud. 2010. "Feasibility of Long-Distance Transport of Thermal Energy Using Solid Sorption Process." International Journal of Energy Research 34, 673-687.

McKellar, M.G. 2011. "An Analysis of Fluids for the Transport of Heat with HTGR-Integrated Steam Assisted Gravity Drainage.” TEV-1351. Idaho Falls: Idaho National Laboratory.

McKellar, M. G. 2010. "Nuclear-Assisted Hydrogen Production Analysis." TEV-693 Rev. 3. Idaho Falls: Idaho National Laboratory.

Moe, W., and M. Holbrook. 2014. "Advanced Small Modular Reactor (AdvSMR) Licensing Plan.” Idaho National Laboratory, INL/EXT-14-31191.

Moe, W. 2014. “Opportunities in SMR Emergency Planning.” Idaho National Laboratory, INL/EXT-14-33137.

Moran, T.H., and L. Oldenski. 2014. "The U.S. Manufacturing Base: Four Signs of Strength." Policy Brief PB14-17. Washington, D.C: Peterson Institute for International Economics. https://piie.com/publications/pb/pb14-18.pdf.

Nasako, K., Y. Ito, and M. Osumi. 1998. "Intermittent Heat Transport Using Hydrogen Absorbing Alloys." International Journal of Hydrogen Energy 23(9), 815-824. 
Next Generation Nuclear Plant Project. (2011). "High Temperature Gas-Cooled Reactor Projected Markets and Preliminary Economics”, INL/EXT-10-19037. Idaho Falls: Idaho National Laboratory. Oldenski, L. 2015. "Reshoring by US Firms: What Do the Data Say?" PB15-14. Policy Brief. Washington, D.C: Peterson Institute for International Economics. https://piie.com/publications/pb/pb15-14.pdf.

NREL (National Renewable Energy Laboratory). 2016. "Industrial Facility Combustion Energy Use". https://doi.org/10.7799/1278644.

NREL (National Renewable Energy Laboratory). 2016a. "Concentrating Solar Power Projects in the United States”. http://www.nrel.gov/csp/solarpaces/by_country_detail.cfm/country=US.

ORNL (Oak Ridge National Laboratory). 2012. G.T. Mays, R.J. Belles, B.R. Blevins, et al., Application of Spatial Data Modeling and Geographical Information Systems (GIS) for Identification of Potential Siting Options for Various Electrical Generation Sources, Report prepared for the Electric Power Research Institute (EPRI), ORNL/TM-2011/157/R1, May 2012.

Pellegrino, J.L., N. Margolis, M. Justiniano, M. Miller, and A. Thedki. 2004. "Energy Use, Loss and Opportunities Analysis: U.S. Manufacturing and Mining.” Washington, D.C: U.S. Department of Energy, Industrial Technologies Program. https://www1.eere.energy.gov/manufacturing/intensiveprocesses/pdfs/energy use loss_opportun ities analysis.pdf.

Petti, D., et al. 2016. "Advanced Demonstration and Test Reactor Options Study.” Idaho National Laboratory, INL/EXT-16-37867.

Petty, S., and G. Porro. 2007. "Updated U.S. Geothermal Supply Characterization.” Prepared for the Thirty-Second Workshop on Geothermal Reservoir Engineering, Stanford University, CA, January 22-24, 2007, NREL/CP-640-41073. Golden, Colorado, National Renewable Energy Laboratory, pp. 24. Web page accessed August 2016. http://www.nrel.gov/docs/fy07osti/41073.pdf.

Pinegar, H. K., M. S. Moats, and H. Y. Sohn. 2011. "Process Simulation and Economic Feasibility Analysis for a Hydrogen-Based Novel Suspension Ironmaking Technology." Steel Research International 82, no. 8: 951-963.

Pitzer, E. W. 1972. "Catalytic Oxidative Dehydrogenation of Butenes to Butadiene." Industrial \& Engineering Chemistry Product Research and Development, Vol. 11, No. 3, 299-302.

Rawlins, J., M. Ashcroft, March 2013, "Small-scale Concentrated Solar Power, a Review of Current Activity and Potential to Accelerate Deployment", https:/www.gov.uk/government/uploads/system/uploads/attachment_data/file/\%20191058/small _scale_concentrated_solar_power_carbon_trust.pdf

Revitalize American Manufacturing and Innovation Act of 2014. 2014. USC. Vol. 15. https://www.congress.gov/113/plaws/publ235/PLAW-113publ235.pdf. 
Ruth, M., Cutler, D., Flores-Espino, F., Stark, G., Jenkin, T., Simpkins, T., Macknick. J. $2016 a$. "The Economic Potential of Two Nuclear-Renewable Hybrid Energy Systems," NREL/TP6A50-66073 (2016)

Ruth, M., Cutler, D., Flores-Espino, F., Stark, G., Jenkin, T. 2016b “The Economic Potential of a Nuclear-Renewable Hybrid Energy System Providing Thermal Energy for Industry - Draft Report, July, 2016.Sabharwall, P., Kim, E.S., McKellar, M., Anderson, N.A., and Patterson, M., "Process Heat Exchanger options for Advanced High Temperature Reactor," INL/EXT-11-21584, Idaho National Laboratory, Idaho, June 2011.

Shahryar, G., Rosen, M., Smith, G.R. 2014, "Integration of Wind Energy, Hydrogen and Natural Gas Pipeline Systems to Meet Community and Transportation Energy Needs: A Parametric Study," Sustainability 6., 2506-2526, 2014.

Slone, T. J., and K. Gerdes. 2008. "Development of Baseline Data and Analysis of Life Cycle Greenhouse Gas Emissions of Petroleum-Based Fuel." National Energy Technology Laboratory.

Solar Energy Industries Association (SEIA). 2016. "Concentrating Solar Power." http://www.seia.org/policy/solar-technology/concentrating-solar-power.

Sohn, H.Y. 2007. "Suspension Hydrogen Reduction of Iron Oxide Concentrate." Accessed August 17, 2016. http://steeltrp.com/Briefing07slides/05-TRP9953 UTAH-07IBS.pdf.

Tester, J., et al. 2005. “Sustainable Energy,” MIT Press.

Tester, J.W., et al. 2006. "The Future of Geothermal Energy: Impact of Enhanced Geothermal Systems (EGS) on the United States in the $21^{\text {st }}$ Century." INL/EXT-06-11746. Cambridge, Massachusetts, Massachusetts Institute of Technology. Web page accessed August 2016. http://www1.eere.energy.gov/geothermal/future_geothermal.html.

Thekdi, A.C., and S.U. Nimbalkar. "Industrial Waste Heat Recovery: Potential Applications, Available Technologies and Crosscutting R\&D Opportunities." Oak Ridge, TN: Oak Ridge National Laboratory, December 25, 2014. http://info.ornl.gov/sites/publications/files/Pub52987.pdf.

Todreas, N. 2015. "Chapter 1: "Small modular reactors (SMRs) for producing nuclear energy: an introduction", In Handbook of Small Modular Nuclear Reactors, by Mario D. Carelli and Daniel T. Ingersoll, p3. Oxford: Elsevier Ltd.

UK Department of Energy \& Climate Change and UK Department for Business, Innovation \& Skills. 2015. "Industrial Decarbonisation and Energy Efficiency Roadmaps to 2050 Publications - GOV.UK." Industrial Decarbonisation and Energy Efficiency Roadmaps to 2050. March 25. https://www.gov.uk/government/publications/industrial-decarbonisation-and-energyefficiency-roadmaps-to-2050.

United Nations Framework Convention on Climate Change. 2015. "Paris Agreement." http://unfccc.int/files/meetings/paris_nov_2015/application/pdf/paris_agreement_english_.pdf. 
U.S. Census Bureau. n.d. "North American Industry Classification System (NAICS)." http://www.census.gov/eos/www/naics/.

U.S. Census Bureau. 2016. “County Business Patterns: 2014.” Accessed June 23. http://www.census.gov/data/datasets/2014/econ/cbp/2014-cbp.html.

U.S. Department of State. 2015. "United States of America Intended Nationally Determined Contribution." United National Framework on Climate Change.

http://www4.unfccc.int/Submissions/INDC/Published\%20Documents/United\%20States\%20of\% 20America/1/U.S.\%20Cover\%20Note\%20INDC\%20and\%20Accompanying\%20Information.pd f.

U.S. Department of Energy. 2016. "Bandwidth Studies." Web page accessed September 7, 2016. http://energy.gov/eere/amo/energy-analysis-sector\#5.

U.S. Department of Energy. 2015a. "Quadrennial Technology Review An Assessment of Energy Technologies and Research Opportunities." Accessed September 16, 2016. http://energy.gov/sites/prod/files/2015/09/f26/Quadrennial-Technology-Review-2015_0.pdf.

U.S. Department of Energy. 2015b. "Improving Process Heating System Performance: A Sourcebook for Industry." Washington, D.C. http://energy.gov/sites/prod/files/2016/04/f30/Improving\%20Process\%20Heating\%20System\%2 0Performance $\% 20 \mathrm{~A} \% 20$ Sourcebook $\% 20$ for $\% 20$ Industry $\% 20$ Third\%20Edition_0.pdf.

U.S. Department of Energy. 2015c. "Process Heating Technology Assessment." Quadrennial Technology Review 2015. Washington, D.C: U.S. Department of Energy. http://www.energy.gov/sites/prod/files/2016/06/f32/QTR2015-6I-Process-Heating.pdf.

U.S. Department of Energy. 2015d. "Waste Heat Recovery Technology Assessment." Quadrennial Technology Review 2015. Washington, D.C: U.S. Department of Energy. http://www.energy.gov/sites/prod/files/2016/02/f30/QTR2015-6M-Waste-Heat-Recovery.pdf.

U.S. Department of Energy. 2015e. "Annual Report Geothermal Technologies Office.” Accessed September 7, 2016. http://www1.eere.energy.gov/geothermal/pdfs/gto_2015 annual_report.pdf.

U.S. Department of Energy. 2015f. "Introduction to CEMI." http://www.energy.gov/sites/prod/files/2015/09/f26/Introduction\%20to\%20CEMI\%20Fact\%20S heet $\% 202015$.pdf.

U.S. Department of Energy. 2015g. "Barriers to Industrial Energy Efficiency". U.S. DOE Energy Efficiency and Renewable Energy. http://www.energy.gov/sites/prod/files/2015/06/f23/EXEC2014-005846 6\%20Report_signed_v2.pdf

U.S. Department of Energy. 2015h. "Solid Oxide Fuel Cells". U.S. Office of Fossil Fuel. http://energy.gov/fe/science-innovation/clean-coal-research/solid-oxide-fuel-cells. 
U.S. Energy Information Administration. 2016. "Refinery Capacity data by individual refinery as of January 1, 2016". Accessed August 2016.

http://www.eia.gov/petroleum/refinerycapacity/refcap16.xls.

U.S. Energy Information Administration. 2016a. "Geothermal Explained: Use of Geothermal Energy". Accessed September 2016.

http://www.eia.gov/energyexplained/index.cfm?page=geothermal_use

U.S. Energy Information Administration. 2015. "2010 Manufacturing Energy Consumption Survey.” 2010 MECS Survey Data. Accessed December 8. http://www.eia.gov/consumption/manufacturing/data/2010/.

U.S. Energy Information Administration. 2008. "The Impact of Increased Use of Hydrogen on Petroleum Consumption and Carbon Dioxide Emissions." Report \#: SR-OIAF-CNEAF/2008-04. www.eia.doe.gov/oiaf/servicerpt/hydro/appendixc.html.

U.S. Environtmental Protection Agency. 2015. "Sources of Greenhouse Gas Emissions." Accessed September 21, 2016. https://www.epa.gov/ghgemissions/sources-greenhouse-gasemissions\#industry.

U.S. Environmental Protection Agency. 2016a. "Inventory of U.S. Greenhouse Gas Emissions and Sinks: 1990-2014.” Washington, D.C: U.S. Environmental Protection Agency. http://www3.epa.gov/climatechange/ghgemissions/usinventoryreport.html.

U.S. Environmental Protection Agency. 2016b. "GHGRP 2014: Reported Data." Data and Tools. Accessed April 5, 2016. https://www.epa.gov/ghgreporting/ghgrp-2014-reported-data.

U.S. Environmental Protection Agency. 2016c. "Subpart C Methodologies Fact Sheet." U.S. Environmental Protection Agency. Accessed April 12, 2016. https://www.epa.gov/ghgreporting/subpart-c-methodologies-fact-sheet.

U.S. Environmental Protection Agency. 2016d. "Greenhouse Gas Customized Search.” U.S. Environmental Protection Agency. Accessed September 1, 2016. https://www.epa.gov/enviro/greenhouse-gas-customized-search.

U.S. Environmental Protection Agency. 2016e. "Envirofacts Data Service API.” U.S. Environmental Protection Agency. Accessed September 1, 2016. https://www.epa.gov/enviro/greenhouse-gas-customized-search.

EPA Center for Corporate Climate Leadership. 2015. "Emission Factors for Greenhouse Gas Inventories." U.S. Environmental Protection Agency. https://www.epa.gov/sites/production/files/2015-12/documents/emission-factors nov 2015.pdf.

United States Geological Survey. 2015. "Iron and Steel Statistics." Accessed August 29, 2016. http://minerals.usgs.gov/minerals/pubs/historical-statistics/ironsteel-use.xls. 
U.S. Nuclear Regulatory Commission. 2016. "Pre-Application Review of the NuScale Design." Webpage accessed August 2016. http://www.nrc.gov/reactors/advanced/nuscale/review.html.

Van den Bossche, P., P. Gupta, J. Gott, B. Levering, and H. Gutierrez. 2014. "U.S. Reshoring: Over Before It Began?" Washington, D.C: A.T. Kearney. https://www.atkearney.com/documents/10192/7070019/US+Reshoring.pdf/14777afa-0c14-460e937b-11233be340b6.

Wei, M., J. Greenblatt, S. Donovan, J. Nelson, A. Mileva, J. Johnston, and D. Kammen. 2014. "Scenarios for Meeting California's 2050 Climate Goals." CEC-500-2014-108. California Energy Commission. http://www.energy.ca.gov/2014publications/CEC-500-2014-108/CEC-5002014-108.pdf.

Wei, M., J.H. Nelson, J.B. Greenblatt, A. Mileva, J. Johnston, M. Ting, C. Yang, C. Jones, J.E. McMahon, and D.M. Kammen. 2013. "Deep Carbon Reductions in California Require Electrification and Integration across Economic Sectors." Environmental Research Letters 8 (1): 014038 .

White, B. 2006. "An Assessment of Geothermal Direct Heat Use in New Zealand.” New Zealand Geothermal Association, Inc., June 14, 2006. Web page accessed August 2016. http://www.nzgeothermal.org.nz/publications/Reports/NZGADirectHeatAssessmentReport_2006 .pdf.

Williams, C.F., M.J. Reed, R.H. Mariner, J. DeAngelo, and S.P. Galanis, Jr. 2008. "Assessment of Moderate- and High-Temperature Geothermal Resources of the United States." U.S. Geological Survey Fact Sheet 2008-3082, p.4. http://pubs.usgs.gov/fs/2008/3082.

Williams, J.H., B. Haley, F. Kahrl, J. Moore, A.D. Jones, M.S. Torn, and H. McJeon. 2015. "Pathways to Deep Decarbonization in the United States." Paris: Institute for Sustainable Development and International Relations and Sustainable Development Solutions Network. http://deepdecarbonization.org/wpcontent/uploads/2015/11/US_Deep_Decarbonization_Technical_Report.pdf.

Wood, Rick A. 2010. "Nuclear-Integrated Ammonia Production Analysis", TEV-666 Rev. 2. Idaho Falls: Idaho National Laboratory.

Wood, Rick A., and Michael G. McKellar. 2013. "Hydrogen Production via FHR-Integrated High-Temperature Steam Electrolysis", TEV-1776. Idaho Falls: Idaho National Laboratory, 2013.

Wood, Rick A., and Michael G. McKellar. 2013. "Methanol Production via FHR-Integrated Steam Methane Reforming", TEV-1752. Idaho Falls: Idaho National Laboratory.

Wortler, M., F. Schuler, N. Voigt, T. Schmidt, P. Dahlmann, H. Bodo Lungen, and J.-Th. Ghenda. 2013. "Steel's Contribution to a Low-Carbon Europe 2050: Technical and Economic Analysis of the Sector's $\mathrm{CO}_{2}$ Abatement Potential." Boston, MA: Boston Consulting Group. http://www.stahl-online.de//wp-content/uploads/2013/09/Schlussbericht-Studie-Low-carbonEurope-2050 -Mai-20131.pdf. 
WRI/WBCSD. 2006. "Allocation of GHG Emissions from a Combined Heat and Power (CHP) Plant.” Washington, D.C: GHG Protocol Initiative.

http://www.ghgprotocol.org/files/ghgp/tools/CHP_guidance_v1.0.pdf.

Yang, C., S. Yeh, K. Ramea, S. Zakerinia, D. McCollum, D. Bunch, and J. Ogden. 2014.

"Modeling Optimal Transition Pathways to a Low Carbon Economy in California: California TIMES (CA-TIMES) Model.” UCD-ITS-RR-14-04. Davis, CA: Institute of Transportation Studies; University of California, Davis. https://trid.trb.org/view.aspx?id=1322426.

Yoon, S.-J., and P. Sabharwall. 2014. "Parametric Study on Maximum Transportable Distance and Cost for Thermal Energy Transportation Using Various Coolants." Progress in Nuclear Energy 74, 110-119. 


\section{APPENDICES}


Appendix A Description of Target Industries

\begin{tabular}{|c|c|c|}
\hline Target Industry & $\begin{array}{l}\text { NAICS } \\
\text { Code }\end{array}$ & Description \\
\hline Petroleum Refineries & 324110 & $\begin{array}{l}\text { Establishments primarily engaged in refining crude petroleum } \\
\text { into refined petroleum. Petroleum refining involves one or } \\
\text { more of the following activities: (1) fractionation; (2) straight } \\
\text { distillation of crude oil; and (3) cracking. }\end{array}$ \\
\hline Iron and Steel Mills & 331111 & $\begin{array}{l}\text { Establishments primarily engaged in one or more of the } \\
\text { following: (1) direct reduction of iron ore; (2) manufacturing } \\
\text { pig iron in molten or solid form; (3) converting pig iron into } \\
\text { steel; (4) making steel; (5) making steel and manufacturing } \\
\text { shapes (e.g., bar, plate, rod, sheet, strip, wire); and (6) } \\
\text { making steel and forming tube and pipe. }\end{array}$ \\
\hline $\begin{array}{l}\text { Paper (except } \\
\text { Newsprint) Mills }\end{array}$ & 322121 & $\begin{array}{l}\text { Establishments primarily engaged in manufacturing paper } \\
\text { (except newsprint and uncoated groundwood paper) from } \\
\text { pulp. These establishments may manufacture or purchase } \\
\text { pulp. In addition, the establishments may also convert the } \\
\text { paper they make. }\end{array}$ \\
\hline Paperboard Mills & 322130 & $\begin{array}{l}\text { Establishments primarily engaged in manufacturing } \\
\text { paperboard from pulp. These establishments may } \\
\text { manufacture or purchase pulp. In addition, the } \\
\text { establishments may also convert the paperboard they make. }\end{array}$ \\
\hline $\begin{array}{l}\text { All Other Basic Organic } \\
\text { Chemical } \\
\text { Manufacturing }\end{array}$ & 325199 & $\begin{array}{l}\text { Establishments primarily engaged in manufacturing basic } \\
\text { organic chemical products (except aromatic petrochemicals, } \\
\text { industrial gases, synthetic organic dyes and pigments, gum } \\
\text { and wood chemicals, cyclic crudes and intermediates, and } \\
\text { ethyl alcohol). }\end{array}$ \\
\hline $\begin{array}{l}\text { Ethyl Alcohol } \\
\text { Manufacturing }\end{array}$ & 325193 & $\begin{array}{l}\text { Establishments primarily engaged in manufacturing } \\
\text { nonpotable ethyl alcohol. }\end{array}$ \\
\hline Wet Corn Milling & 311221 & $\begin{array}{l}\text { Establishments primarily engaged in wet milling corn and } \\
\text { other vegetables (except to make ethyl alcohol). Examples of } \\
\text { products made in these establishments are corn sweeteners, } \\
\text { such as glucose, dextrose, and fructose; corn oil; and } \\
\text { starches (except laundry). }\end{array}$ \\
\hline $\begin{array}{l}\text { Plastics Material and } \\
\text { Resin Manufacturing }\end{array}$ & 325211 & $\begin{array}{l}\text { Establishments primarily engaged in (1) manufacturing } \\
\text { resins, plastics materials, and nonvulcanizable thermoplastic } \\
\text { elastomers and mixing and blending resins on a custom } \\
\text { basis and/or (2) manufacturing noncustomized synthetic } \\
\text { resins. }\end{array}$ \\
\hline $\begin{array}{l}\text { Petrochemical } \\
\text { Manufacturing }\end{array}$ & 325110 & $\begin{array}{l}\text { Establishments primarily engaged in (1) manufacturing } \\
\text { acyclic (i.e., aliphatic) hydrocarbons such as ethylene, } \\
\text { propylene, and butylene made from refined petroleum or } \\
\text { liquid hydrocarbons and/or (2) manufacturing cyclic aromatic } \\
\text { hydrocarbons such as benzene, toluene, styrene, xylene, } \\
\text { ethyl benzene, and cumene made from refined petroleum or }\end{array}$ \\
\hline
\end{tabular}




\begin{tabular}{|l|l|l|}
\hline $\begin{array}{l}\text { Alkalies and Chlorine } \\
\text { Manufacturing }\end{array}$ & 325181 & $\begin{array}{l}\text { liquid hydrocarbons. } \\
\text { Establishments primarily engaged in manufacturing chlorine, } \\
\text { sodium hydroxide (i.e., caustic soda), and other alkalies often } \\
\text { using an electrolysis process. }\end{array}$ \\
\hline Pulp Mills & 322110 & $\begin{array}{l}\text { Establishments primarily engaged in manufacturing pulp } \\
\text { without manufacturing paper or paperboard. The pulp is } \\
\text { made by separating the cellulose fibers from the other } \\
\text { impurities in wood or other materials, such as used or } \\
\text { recycled rags, linters, scrap paper, and straw. }\end{array}$ \\
\hline Lime Manufacturing & 327410 & $\begin{array}{l}\text { Establishments primarily engaged in manufacturing lime from } \\
\text { calcitic limestone, dolomitic limestone, or other calcareous } \\
\text { materials, such as coral, chalk, and shells. Lime } \\
\text { manufacturing establishments may mine, quarry, collect, or } \\
\text { purchase the sources of calcium carbonate. }\end{array}$ \\
\hline $\begin{array}{l}\text { Nitrogenous Fertilizer } \\
\text { Manufacturing }\end{array}$ & 325311 & $\begin{array}{l}\text { Establishments primarily engaged in one or more of the } \\
\text { following: (1) manufacturing nitrogenous fertilizer materials } \\
\text { and mixing ingredients into fertilizers; (2) manufacturing } \\
\text { fertilizers from sewage or animal waste; and (3) } \\
\text { manufacturing nitrogenous materials and mixing them into } \\
\text { fertilizers. }\end{array}$ \\
\hline $\begin{array}{l}\text { Potash, Soda, and } \\
\text { Borate Mineral Mining }\end{array}$ & 212391 & $\begin{array}{l}\text { Establishments primarily engaged in developing the mine } \\
\text { site, mining and/or milling, or otherwise beneficiating (i.e., } \\
\text { preparing) natural potassium, sodium, or boron compounds. } \\
\text { Drylake brine operations are included in this industry, as well } \\
\text { as establishments engaged in producing the specified } \\
\text { minerals from underground and open pit mines. }\end{array}$ \\
\hline
\end{tabular}

Source: U.S. Census Bureau, n.d.

U.S. Census Bureau. n.d. "North American Industry Classification System (NAICS)." http://www.census.gov/eos/www/naics/. 
Appendix B Calculated Energy by End Use and Target Industry in 2014

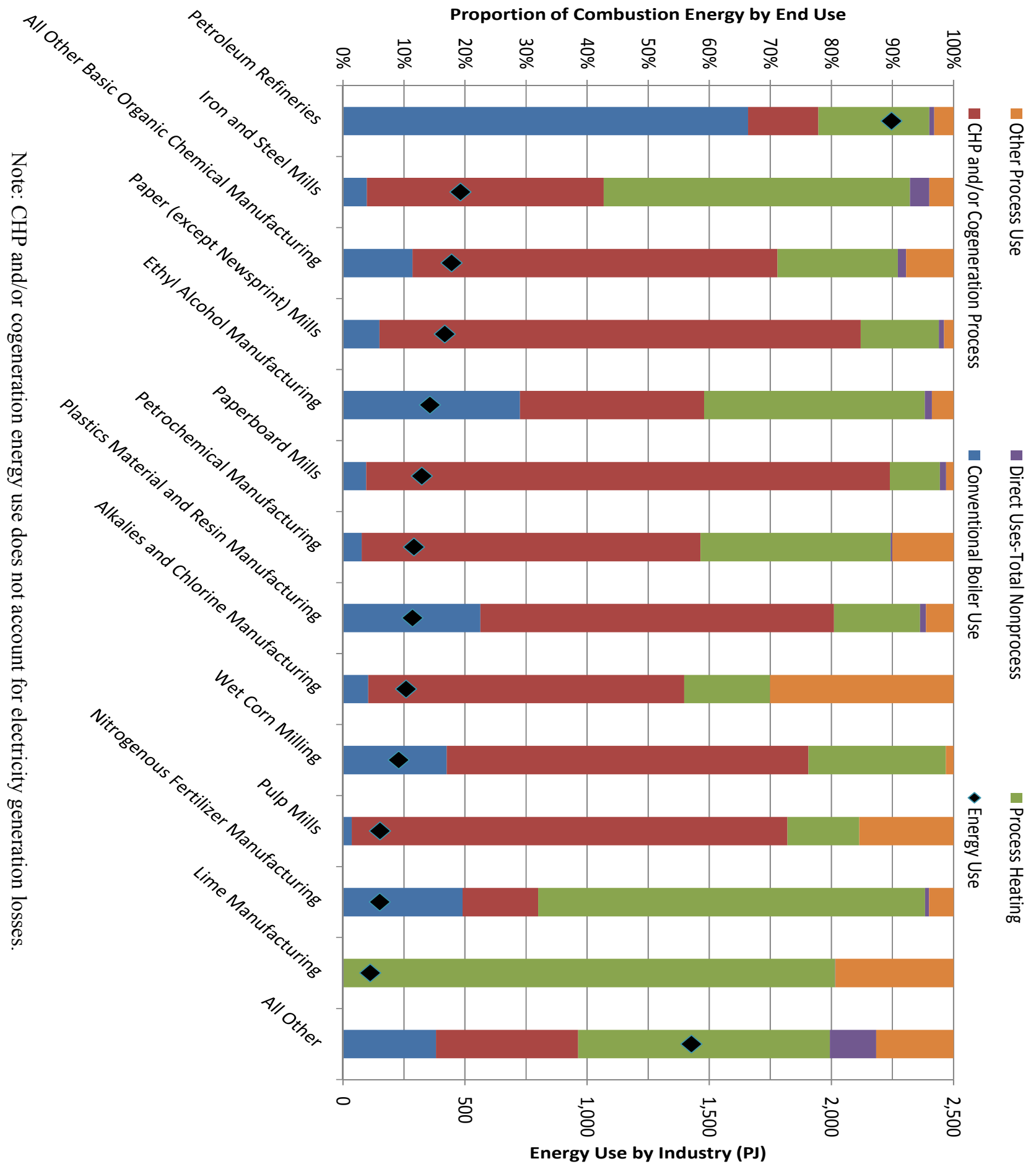




\section{Appendix C Petroleum Refinery}

Currently there are 139 operating refineries in the United States. Most are located along the Gulf Coast with California taking the next largest cluster. 18 million barrels of crude oil are processed each day (Administration 2016). A summary of a typical smaller refinery is shown in Figure A-1. The data for the following Figures and Tables primarily come from a report by the National Energy Technology Laboratory (Skone and Gerdes 2009). Additional data are taken from Chemical Engineering Progress (Olson 2014) and a report on a Chevron refinery (Chevron 2014). Coal, natural gas or purchased steam can provided heat to the refinery. The values of coal, natural gas, and steam are based on total heat steams into the U.S. refineries but are normalized to the plant size shown in Figure A-1.

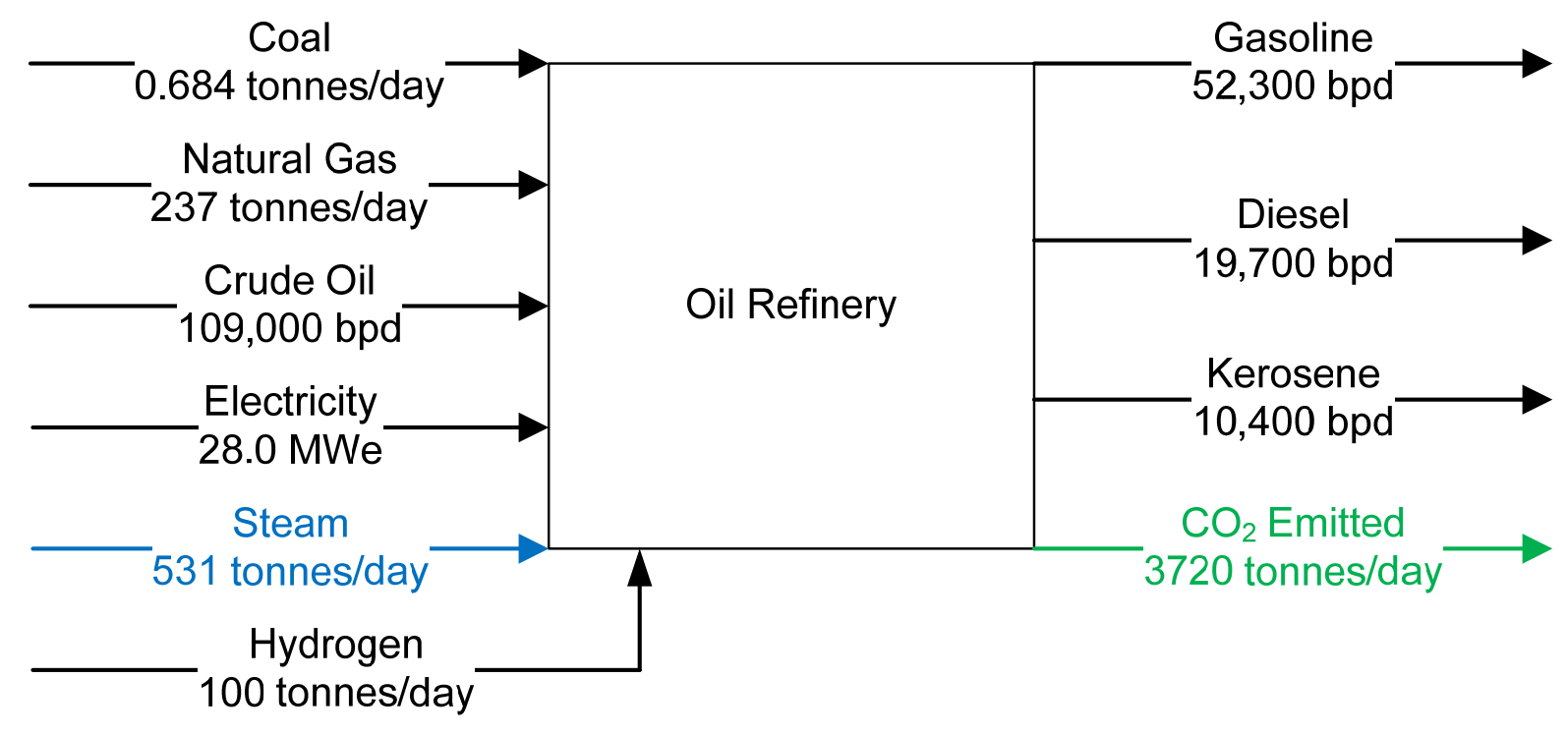

Figure C-1. Overall Material and Energy Flows for a Nominal Crude Oil Refinery

\section{C.1 Description}

- Desalter: Water is added to the crude oil to dissolve the salts within. The brine is separated from the oil using electric grids. Salts are removed to mitigate vessel and piping fouling and corrosion.

- Fired Heater: The desalted oil is preheated by several heat exchangers and a fired heater. Up to $50 \%$ of the heat comes from products and side-cuts of the refinery process through recuperative heat exchange, the remaining heat comes from the fired heater. The oil is heated between 340 and $370^{\circ} \mathrm{C}$.

- Atmospheric Crude Fractionator: The fractionator separates the crude oil into fractions or cuts based upon the boiling point ranges of the components. Lighter fractions come off the top with increasingly heavier components pulled further down the tower. Table A-1 shows typical cut points for components exiting the fractionator. The crude oil leaves the desalting process at $115^{\circ} \mathrm{C}$ to $150^{\circ} \mathrm{C}$. The crude is preheated from products leaving the fractionator raising the crude temperature to approximately $288^{\circ} \mathrm{C}$. A direct-fired furnace heats the crude to $343-400^{\circ} \mathrm{C}$ before entering the atmospheric fractionator. The atmospheric fractionator is a 
distillation column that operates at atmospheric pressure. The column contains 30 to 50 separation trays which correspond to different boiling temperatures. Crude oil vapor rises up the column, passing through perforations in each tray while contacting condensing liquids on each tray. Heavier liquids flow down to lower trays until they begin to boil. The vapor will condense at a tray that corresponds to its point and remain at that tray. The higher, cooler trays contain a mix of lighter compounds while lower, hotter trays will collect the heavier components. At several levels in the column liquid products are drawn off and are further processed.

- Vacuum Fractionator: Downstream of the atmospheric fractionator, the vacuum fractionator operates under a vacuum to separate the heavy, higher boiling point components. The vacuum decreases the boiling temperatures of the components. The temperature reduction will prevent the initiation of thermal cracking.

- Gas Concentration Unit: The light gases coming from the atmospheric crude fractionator are concentrated and separated within the gas concentration unit. Typically they are separated as wet streams called liquefied petroleum gas (LPG) comprised of propane and butane and dry gases such as ethane and methane. The separation process is accomplished through distillation columns. The dry gases are typically used as fuel throughout the refinery for fired heaters and boilers. Purchased natural gas supplements this fuel as needed.

- Fluidized Catalytic Cracker: The fluidized catalytic cracker (FCC) breaks long chain hydrocarbons such as heavy gas oil into shorter chains such as naphtha. The endothermic cracking reactions occur at temperatures from 480 to $540^{\circ} \mathrm{C}$ and are fueled by the heat produced during catalyst-regeneration. About $5 \%$ of the feed ends up as coke; therefore, air is used in the regenerator to burn the coke off. The exit temperatures of the regenerator ranges between 815 to $925^{\circ} \mathrm{C}$. A fractionator column is used downstream of FCC to separate and recover the hydrocarbon vapors.

- Alkylation Unit: The alkylation unit mixes olefins produced in the FCC unit with isobutene to form alkylate. Alkylate is blended with gasoline to raise its octane rating.

- Butane Isomerization: Isobutane gives a better octane level to alkylate than n-butane. For this reason, the isomerization process converts isobutene to isobutane using excess hydrogen and a catalyst. A distillation column separates n-butane from isobutane.

- Light Naphtha Isomerization Unit: The light naphtha isomerization unit converts $\mathrm{n}$-pentane and n-hexane into isopentane and isohexane in the presence of excess hydrogen and a catalyst. A distillation column removes butane and lighter gases.

- Heavy Naphtha Reformer and Hydrotreater: The heavy naphtha reformer increases the gasoline octane rating by converting naphthenes into aromatics and generating a reformate gasoline product. The reforming process is endothermic using three to four reactors and a fired heater. The reforming process produces hydrogen which is used by the refinery's hydrocracking and hydrotreating processes. Hydrotreaters throughout the refinery process are used to remove impurities such as sulfur, nitrogen, oxygen, metallic salts, olefins, and some aromatics. Hydrotreaters do not affect the boiling range of the feed.

- Hydrocracking: Hydrocrackers use hydrogen to maximize ultra-low-sulfur diesel and jet fuel. Hydrocrackers operation at pressures of about $20 \mathrm{MPa}$. The overall demand for 
hydrogen exceeds the quantity generated in the refinery in the various process stages.

Therefore, a hydrogen generation unit operation is necessary or hydrogen is purchased from an external supplier. The cracking reactions are endothermic but concurrent hydrotreating reactions make the overall process exothermic. Reactor temperatures range from 290 to $450^{\circ} \mathrm{C}$. The addition of hydrogen increases the production of isoparaffins and limits the production of olefins. A fractionator is used to separate the light gases, gasoline, and diesel.

- Delayed Coking and Asphalt Production: The delayed coker cracks heavy feedstocks to produce solid coke and light hydrocarbons that are blended in gasoline. The vacuum fractionator bottoms are sent with steam to a fired heater and then to a drum where the mixture is thermally cracked to make coke and vapor products. The vapors are returned to the bottom of the fractionator. Without the cracking unit, refineries can sell the vacuum residuum or produce asphalt.

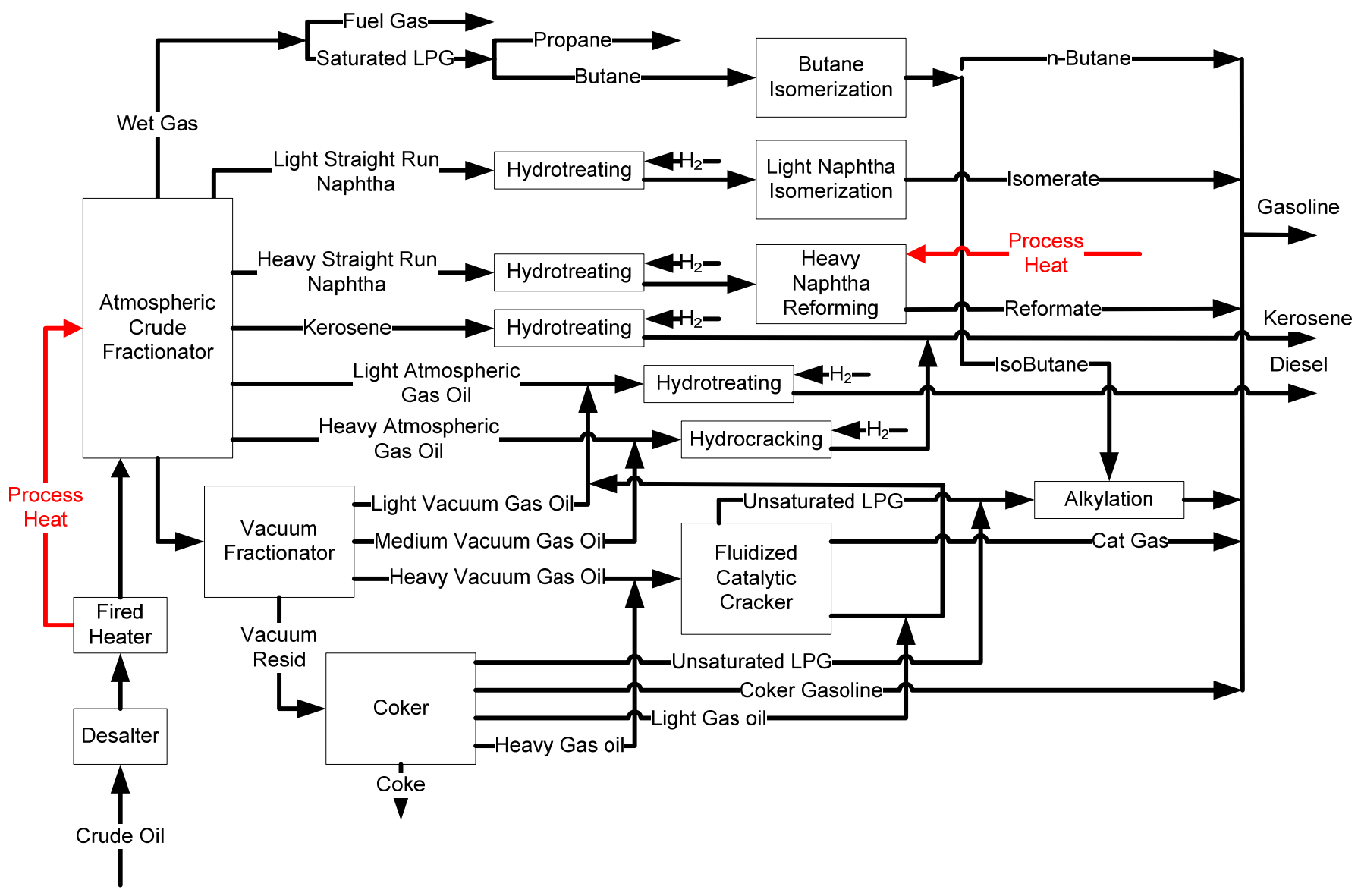

Figure C-2. Schematic of oil refinery process

Table C-1. Typical cut points for atmospheric and vacuum fractionators

\begin{tabular}{lc} 
Component & Cut Temperatures $\left({ }^{\circ} \mathbf{C}\right)$ \\
\hline \hline Atmospheric Crude Fractionator & \\
Light straight-run (LSR) naphtha & $32-88$ \\
Heavy straight-run (HSR) naphtha & $88-166$ \\
Kerosene & $166-249$ \\
Light atmospheric gas oil (LAGO) & $249-321$
\end{tabular}




\begin{tabular}{lc} 
Heavy atmospheric gas oil (HAGO) & $321-427$ \\
\hline Vacuum Fractionator & $427-566$ \\
Vacuum gas oil (VGO) & $>566$ \\
Vacuum-reduced crude (VRC)
\end{tabular}

Table C-2. Refinery Results

\section{Crude Oil Refinery Results}

\begin{tabular}{lc}
\hline \hline Inputs & \\
Crude Oil (barrels per day) & 109,000 \\
Natural Gas (tonnes/day) & 237 \\
Coal (tonnes/day) & 0.684 \\
Hydrogen (tonnes/day) & 100 \\
Electricity (MWe) & 28.0 \\
Steam (tonnes/day) & 531 \\
\hline Products & \\
Gasoline (barrels per day) & 52,300 \\
Diesel (barrels per day) & 19,700 \\
Kerosene (barrels per day) & 10,400 \\
\hline Fuels Produced and Used by Refinery Process & (barrels per day) \\
Liquefied Petroleum Gases & 76.8 \\
Distillate Fuel Oil & 13.9 \\
Residual Fuel Oil & 40.6 \\
Still Gas & 4380 \\
Petroleum Coke & 1650 \\
Other Petroleum Products & 98.0 \\
\hline $\mathrm{CO}_{2}$ Emissions & \\
Emitted (tonnes/day CO 2 ) & 3720 \\
\hline Heat Produced from External Sources (terajoules/day) & \\
Natural Gas & 11.3 \\
Coal & 0.0209 \\
Steam & 1.37 \\
\hline
\end{tabular}

\section{C.2 References}

Administration, U.S. Energy Information. 2016. Petroleum and other liquids. June 22. Accessed July 15, 2016. https://www.eia.gov/dnav/pet/pet_pnp_cap1_dcu_nus_a.htm.

Chevron. March 2014. Chevron Refinery Modernization Project EIR: Appendix 3: Overview of Oil Refining Process. Chevron.

Olson, Tim. 2014. "An Oil Refinery Walk-Through." AIChE: Chemical Engineering Progress, May: 34-40. 
Skone, Timothy J., and Kristin Gerdes. 2009. Developement of Baseline Data and Analysis of Life Cycle Greenhouse Gas Emissions of Petroleum-Based Fuels, DOE/NETL-2009/1346. South Park Township: National Energy Technology Laboratory. 


\section{Appendix D Iron and Steel Mill}

Iron and steel manufacturing are some of the most energy-intensive industries worldwide. In 2008 , the U.S. iron and steel industry consumed a total of $1,466.52 \mathrm{PJ}^{\mathrm{x}}$ of energy to produce for producing 93.7 million tonnes of steel (Worrell et al. 2010). Two processes are mostly used for production of steel: traditional reduction of iron ore and recycling of scrap metal. Iron ore is used to produce plate and ductile iron products that require "cold working" and high tensile strength. It is also used for iron steel alloy. Scrap metal recycling is used to produce lower quality steel, including structural beams, reinforcing bars, and other products that require a minimal amount of cold working

In the iron ore reduction process, sintered or pelletized iron ore (mainly iron oxides found in magnetite, hematite, limonite) is reduced in a blast furnace using coke, combined with injected coal or oil, and with limestone, that is used as a fluxing agent to produce pig iron in a blast furnace. The purpose of the blast furnace is to chemically reduce and physically convert iron oxides (raw ore, pellets, or sinter) into molten iron also referred as hot metal. Reducing gases (hydrogen and carbon monoxide) are produced by partial combustion of the coke. For steel production, the carbon content in iron is reduced and other elements such as manganese and nickel are added to give specific/desired properties to steel. Direct reduction of iron ore is also becoming popular given the volatility of coke, and to address concern for $\mathrm{CO}_{2}$ emissions from coking ovens. Natural gas and hydrogen gas mixtures are effective at reducing iron ore.

Recycled scrap metal steel production requires adding scrap metal to an electric arc furnace. The emissions from the electric-arc process are much lower compared to traditional reduction of iron ore, but the emissions depend on the source of electricity and graphite electrode burn-off. Even though the United States has built numerous small steel recycling plants, there is little additional projected growth. High demand for scrap metal has created a shortage in supply that will likely continue to decline and thus will suppress the recycled scrap metal market in the future. Figure B-1, shows the material and energy flows for a nominal iron and steel production plant, the total heat required of $10.3 \mathrm{TJ} /$ day (combination of coal and natural gas), is assumed to be met by natural gas.

$\mathrm{x} 1 \mathrm{PJ}=1000 \mathrm{TJ}$ 


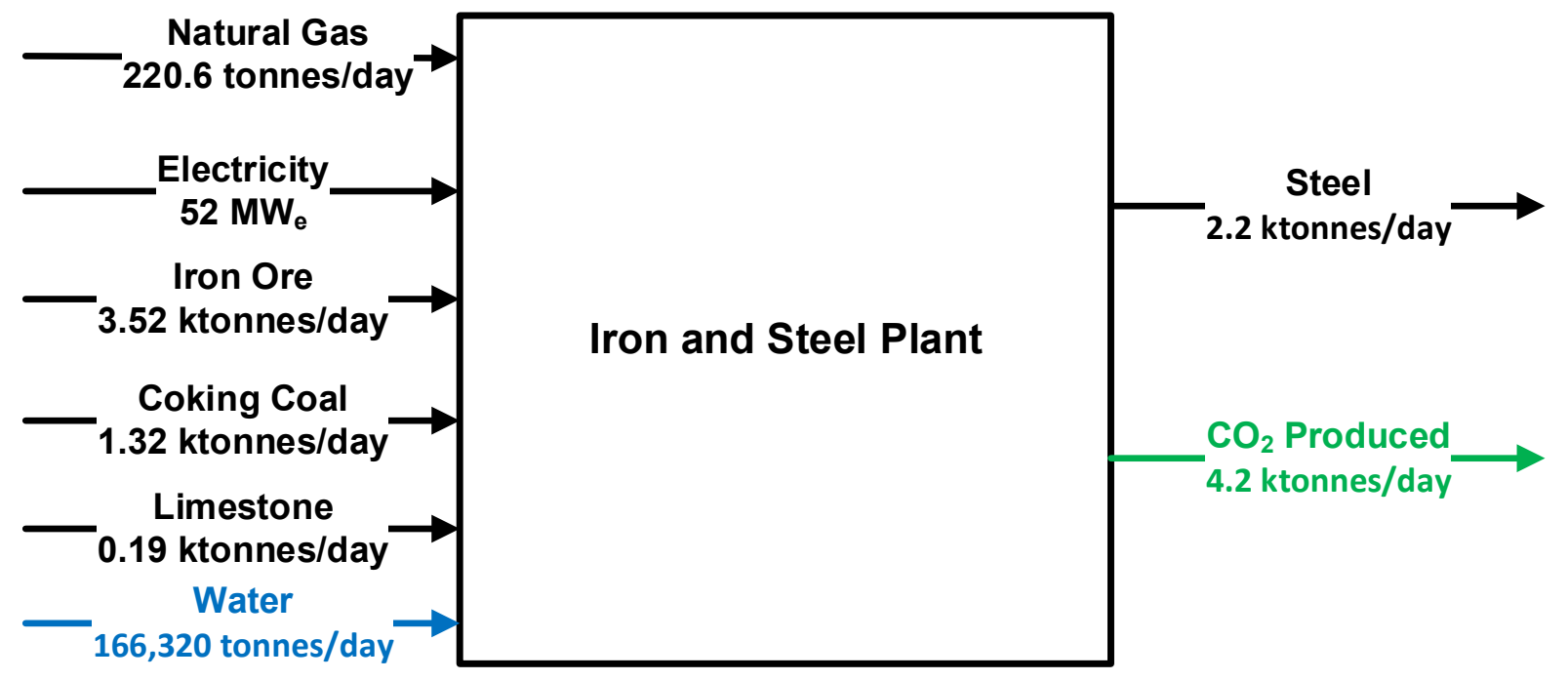

Figure D-1. Material and energy flows for a nominal iron and steel production plant

\section{D.1 Process}

Iron and steel production is a very energy intensive process. As shown in the process flow diagram (Worrell et al. 2010), the main input feeds for making 1 tonne of pig iron are approximately 2 tonnes of ore, 1 tonne of coke, 0.5 tonne of limestone, and about 3.5 tonne of air. Iron oxides enter the blast furnace in the form of ore, pellets, or sinter. Sintering is essential to improve the permeability of the oxides in the blast furnace and to make it easier to reduce. The product obtained from the blast furnace is a hot metal (pig iron), which contains 3-4\% carbon and some other impurities. The crude steel produced reduction of iron ore and recycled scrap is cast into ingots and subsequently reheated and rolled to produce billets and slabs. Essential steps in iron and steel production are broken down as follows:

Coke Production: This process carbonizes coal with high temperatures (around $1,100^{\circ} \mathrm{C}$ ) in an oxygen-deficient atmosphere. The purpose of processing is to provide heat, necessary for attainment of desirable chemical equilibriums and adequate rates of reaction, and to provide gasreduced $\mathrm{CO}$ for reduction of iron oxide.

Blast Furnace: The blast furnace is lined with refractory firebrick, which allows the furnace to maintain a high temperature. In the furnace, limestone is added as a flux to react with principle impurities (such as alumina and silica), to form a slag that is lighter than the molten iron, that floats on the latter in the furnace bottom. The main feed (inputs) goes through various chemical and physical reactions while descending to the bottom of the furnace (American Iron and Steel Institute 2015):

$$
\begin{aligned}
& 3 \mathrm{Fe}_{2} \mathrm{O}_{3}+\mathrm{CO} \rightarrow \mathrm{CO}_{2}+2 \mathrm{Fe}_{3} \mathrm{O}_{4} \\
& \mathrm{Fe}_{3} \mathrm{O}_{4}+\mathrm{CO} \rightarrow \mathrm{CO}_{2}+3 \mathrm{FeO} \quad \text { (begins at } 455^{\circ} \mathrm{C} \text { ) } \\
& \mathrm{FeO}+\mathrm{CO} \rightarrow \mathrm{CO}_{2}+\mathrm{Fe} \quad \text { (begins at } 594^{\circ} \mathrm{C} \text { ) }
\end{aligned}
$$

or 


$$
\mathrm{FeO}+\mathrm{C} \rightarrow \mathrm{CO}+\mathrm{Fe}
$$

The coke introduced at the top of the furnace descends to the bottom where hot blast air enters the blast furnace, igniting the coke and producing carbon dioxide and heat. Since this reaction takes place in the presence of excess carbon, the $\mathrm{CO}_{2}$ reduces to $\mathrm{CO}$, which is necessary to reduce the iron ore (as shown in the equations above) to produce hot metal.

Basis Oxygen Process/Furnace: In this process, the hot metal and steel scrap are oxidized to remove impurities, and air is replaced by pure oxygen at a pressure of $0.965-1.241 \mathrm{MPa}$. The oxygen then produces iron oxide in the melt, oxidizes carbon, and evolves the carbon monoxide and carbon dioxide. Fluxing agents (lime and fluorspar) are added, which helps form the slag that is removed with liquid steel. Gases and slag particles reaching the outlet gas stream are scrubbed before being exhausted to the atmosphere.

Electric Arc Furnace Process: This process is a batch melting process producing batches of molten steel known as "heats." The process was originally solely used to make high-quality steel, such as that used for machine tools, as this process gave more precise control over the composition. In this process, rough electrodes are heated to $2,204^{\circ} \mathrm{C}$, which converts the coke to graphite (American Iron and Steel Institute 2015). Rough electrodes (also known as graphite electrodes) provide high levels of electrical conductivity to help sustain high-heat rates. As melting of hot metal occurs, the electrodes burn, creating a molten metal. A slag is formed from the oxidized impurities and reaction with the lime. After this, the slag and liquid steel are collected separately.

Table D-1 provides a detailed breakdown of steel production energy requirements and emissions. 


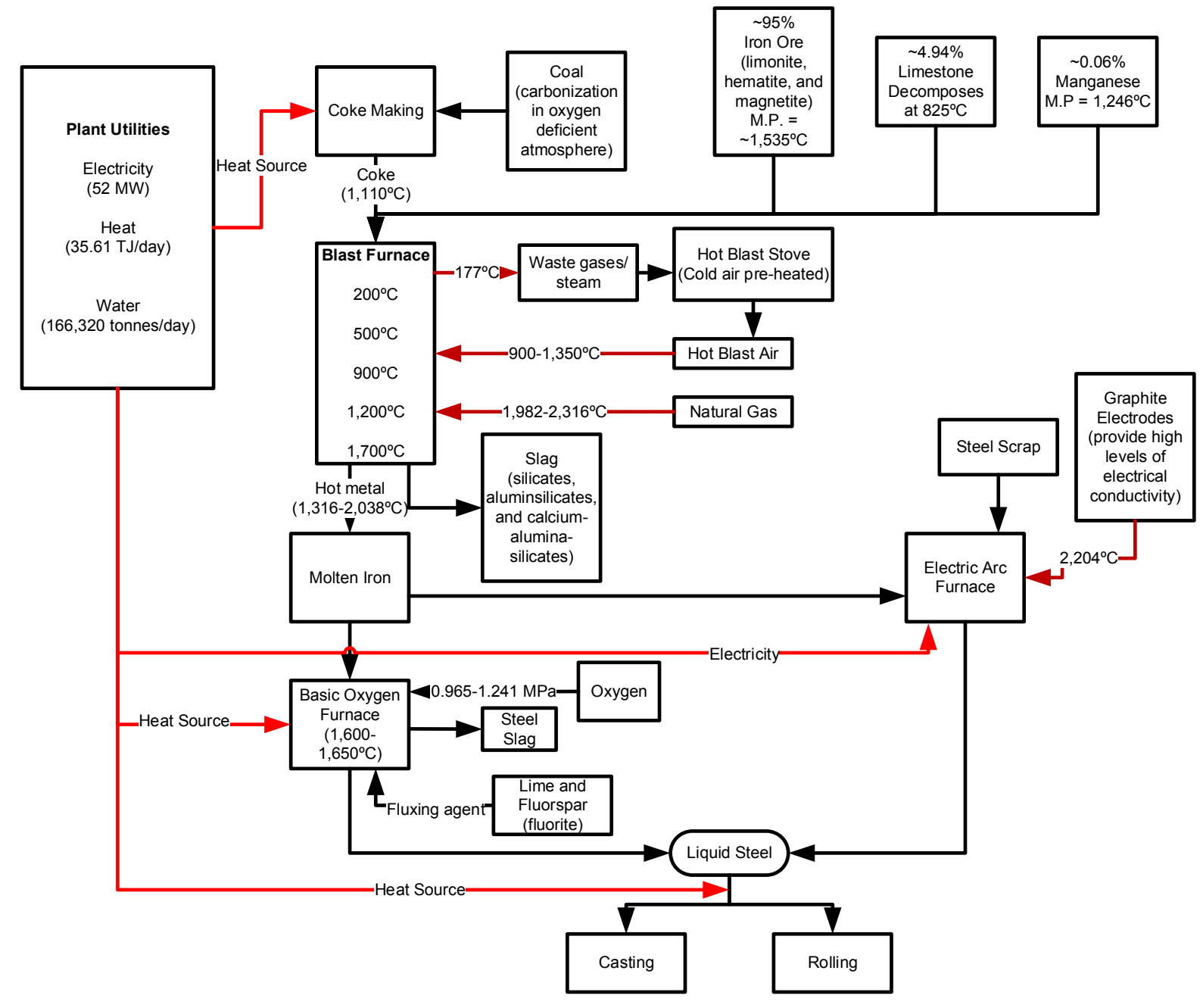

Figure D-2. Iron and steel production process flow diagram 
Table D-1. Net energy inputs and emissions for steel production

\begin{tabular}{|c|c|c|}
\hline Net Steel produced (2008) & 93.7 Mt & \\
\hline Number of Facilities in US & 116 & \\
\hline \multicolumn{3}{|l|}{ Blast Furnace Energy Balance (Hot Metal) } \\
\hline Energy Input (TJ) & & $\%$ \\
\hline Sensible Heat of Hot Blast & $1.54 \mathrm{E}+05$ & 41 \\
\hline Combustion of Coke & $1.97 \mathrm{E}+05$ & 52 \\
\hline Combustion of Injected Fuel & $2.53 E+04$ & 7 \\
\hline Total & $3.76 \mathrm{E}+05$ & 100 \\
\hline \multicolumn{3}{|l|}{ Energy Output (TJ) } \\
\hline Reduction of Iron Oxides & 1.10E+05 & 29 \\
\hline Reduction of other Metalloids & $1.41 \mathrm{E}+04$ & 4 \\
\hline Sensible Heat of Slag & $4.50 \mathrm{E}+04$ & 12 \\
\hline Sensible Heat of Hot Metal & $1.27 \mathrm{E}+05$ & 34 \\
\hline Sensible Heat of Top Gas & $1.87 \mathrm{E}+04$ & 5 \\
\hline Decomposition of $\mathrm{H}_{2} \mathrm{O}$ at raceway & $2.44 \mathrm{E}+04$ & 6 \\
\hline Vaporization of $\mathrm{H}_{2} \mathrm{O}$ from Burden & $1.22 \mathrm{E}+04$ & 3 \\
\hline Heat Losses & $2.44 \mathrm{E}+04$ & 6 \\
\hline Total & $3.76 \mathrm{E}+05$ & 100 \\
\hline \multicolumn{3}{|l|}{ Inputs: Utility Summary (Iron \& Steel) } \\
\hline Total Energy Consumption Iron \& Steel, 2008 (PJ) & 1,467 & \\
\hline Avg. Energy Consumption Iron \& Steel per facility, 2010 (PJ) & 13 & \\
\hline Power Requirement (MWe) & 52 & \\
\hline \multicolumn{3}{|l|}{ Avg. Break Down of Energy Use by Fuel (TJ/day) } \\
\hline Net Coal Consumption $(2 \%)$ & 0.693 & \\
\hline Natural Gas Consumption (27\%) & 9.340 & \\
\hline Electricity Consumption (13\%) & 4.500 & \\
\hline Coke Consumption (36\%) & 12.450 & \\
\hline Other* $(22 \%)$ & 7.610 & \\
\hline Water Consumption (gallons/tonnes) & $13,000-23,000$ & \\
\hline Avg. Water Flow (tonnes/day) & $166,320.00$ & \\
\hline \multicolumn{3}{|l|}{ Outputs } \\
\hline Steel (Mt/day) & 0.26 & \\
\hline \multicolumn{3}{|l|}{$\mathrm{CO}_{2}$ Emissions (kt/day) } \\
\hline Ore-Pellet-Coke-Blast Furnace-BOF & $5.16 \mathrm{E}+02$ & \\
\hline Ore-Pellet-Corex Furnace-BOF & $7.93 \mathrm{E}+02$ & \\
\hline
\end{tabular}




\begin{tabular}{|l|l|l|}
\hline Ore-Pellet-Midrex-EAF & $4.81 \mathrm{E}+02$ & \\
\hline Scrap-EAF & $1.65 \mathrm{E}+02$ & \\
\hline $\begin{array}{l}\text { Other* refers to net steam (sum of purchases, generation from renewables, and net transfers), and other } \\
\text { energy that respondents indicated was used to produce heat and power (LBNL-4779E). Average refers to } \\
\text { value per facility. Note: } t \text { refers to metric tonnes. }\end{array}$ \\
\hline
\end{tabular}

Kirk-Othmer 2016, Elshennawy and Weheba 2015, Worrell 2010). 


\section{Appendix E Paper and Paperboard Mills}

The annual world production of paper and paperboard exceeds 330 million metric tonnes. In 2004, the United States produced 92 million metric tonnes, of which 42 million tonnes were classed as paper products and 50 million tonnes were products heavy enough to be classed as paperboard. Paper's is mainly comprised of cellulosic fibers, mineral products, and bonding agents, including starch and latex products. Paper products normally weigh below $100-150 \mathrm{~g} / \mathrm{m}^{2}$ versus paperboard products, which are generally thicker and stiffer. Paper and paperboard mills mainly use wood pulp as the raw material. The process for pulp production is addressed in Appendix F.

The pulp and paper industry relies on the diverse fuel mix that encompasses fossil fuels, as well as wood waste and byproducts. A large portion $(\sim 75 \%)$ is used for the production of steam and power in onsite systems (Miller et al. 2005). Excess power (if available) is fed back to the grid. Paper mills mainly use biomass/power boilers for production of steam and power for onsite systems.

Paper manufacturing takes homogeneous pulp slurry as an input feedstock, which is formed into sheets for pressing and drying. The largest use of fuels is to generate boiler steam. ${ }^{\mathrm{y}}$ The U.S. pulp and paper industry is the largest self-generator of electricity in the U.S. manufacturing sector (DOE-EIA 2007). A combination of high steam and on-site electricity (combined heat and power) is an ideal and attractive option for many mills around the country. The material and energy flows for a nominal paper and paperboard plant is shown Figure E-1 based on the number of facilities and total production of paper and paperboard in the U.S. in 2002, the total heat required of $3.27 \mathrm{TJ} /$ day, is met by steam from biomass boiler.

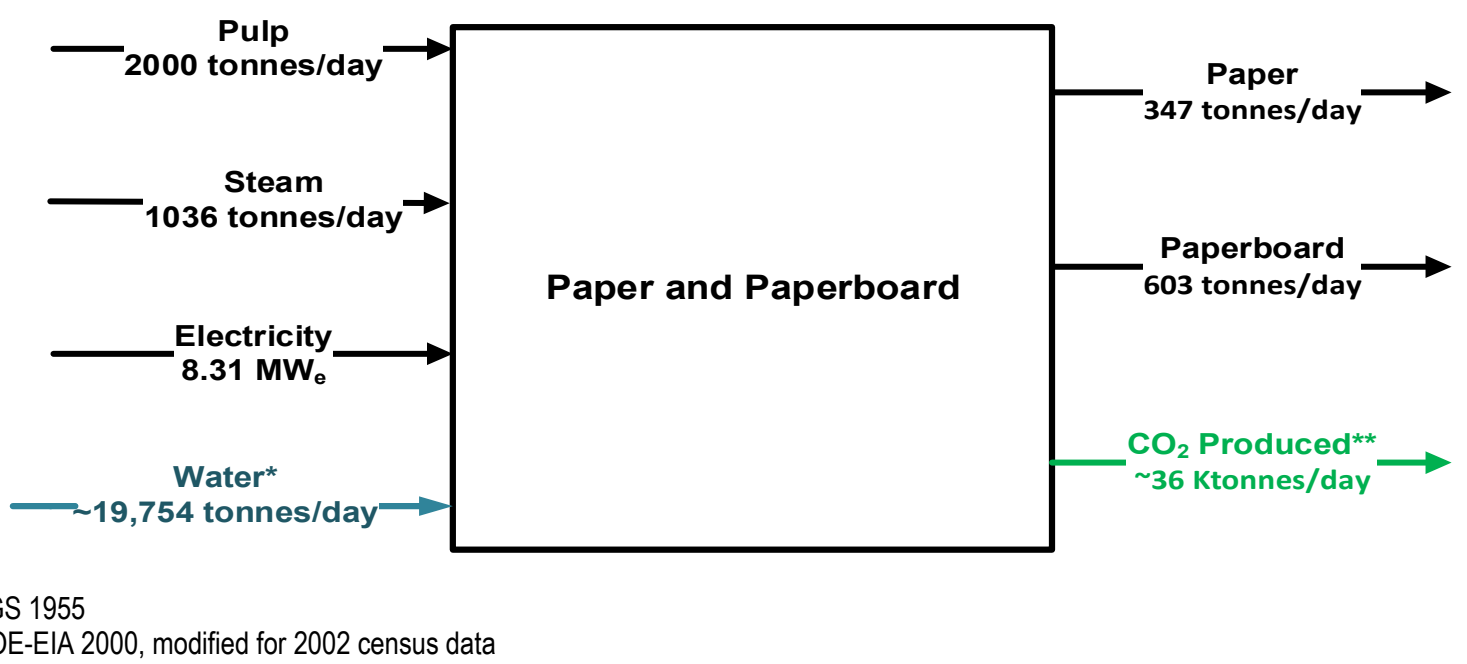

Figure E-1. Material and energy flows for a nominal paper and paperboard plant.

${ }^{y}$ Note: Currently, the Halden Reactor (a boiling water research reactor [25 MWt]) provides steam at $200^{\circ} \mathrm{C}$ at 0.6 MPa to the paper mill, and condensate/cold water is returned back to the reactor (Wiesenack 2016). 


\section{E.1 Process Flow Diagram and Description}

Paper mills convert fibrous pulp (input feedstock) into paper and paperboard. Papermaking can be divided into three main stages (Kramer et al. 2009): (1) stock preparation, (2) wet-end processing (where sheet formation occurs), and (3) dry-end processing (where sheets are dried and finished).

Stock Preparation: The first step is bleaching the pulp to remove the lignin content in the slurry to increase brightness. Unbleached pulp is used for paperboard production (such as corrugated boxes). As shown in Figure 2, the stock preparation involves: mechanical homogenization of pulp, dispersion in water, fiber declustering, additives addition, and blending and contaminant screening. Additives provide the specific desirable properties needed in the final product.

Wet-End Processing: The slurry from the stock preparation process is then fed into the wet-end papermaking process, where a paper web (i.e., sheets) is formed, transforming the volume of the diluted pulp into a fine, wide, and uniform laminate. Additional water is removed to increase fiber bonding. The pulp is then moved to the press section, where the remaining moisture content is squeezed from the paper.

Dry-End Processing: The bonded and dewatered sheet is fed into the dry-end papermaking process and goes through drying, calendaring, and reeling. For drying, steam heated rollers compress and further dry the sheet through evaporation, which helps in additional bonding of fibers. Part way through the cycle, the cylinder is a size press, which is commonly used in the paper industry to apply the required coating. The process continues with cylinders/steam rollers to dry the applied coating. The calendaring process (pressing the sheet with a roll) controls the thickness and smoothness of the paper using polished iron rollers and finished paper is wound on a large reel for storage and transportation. 


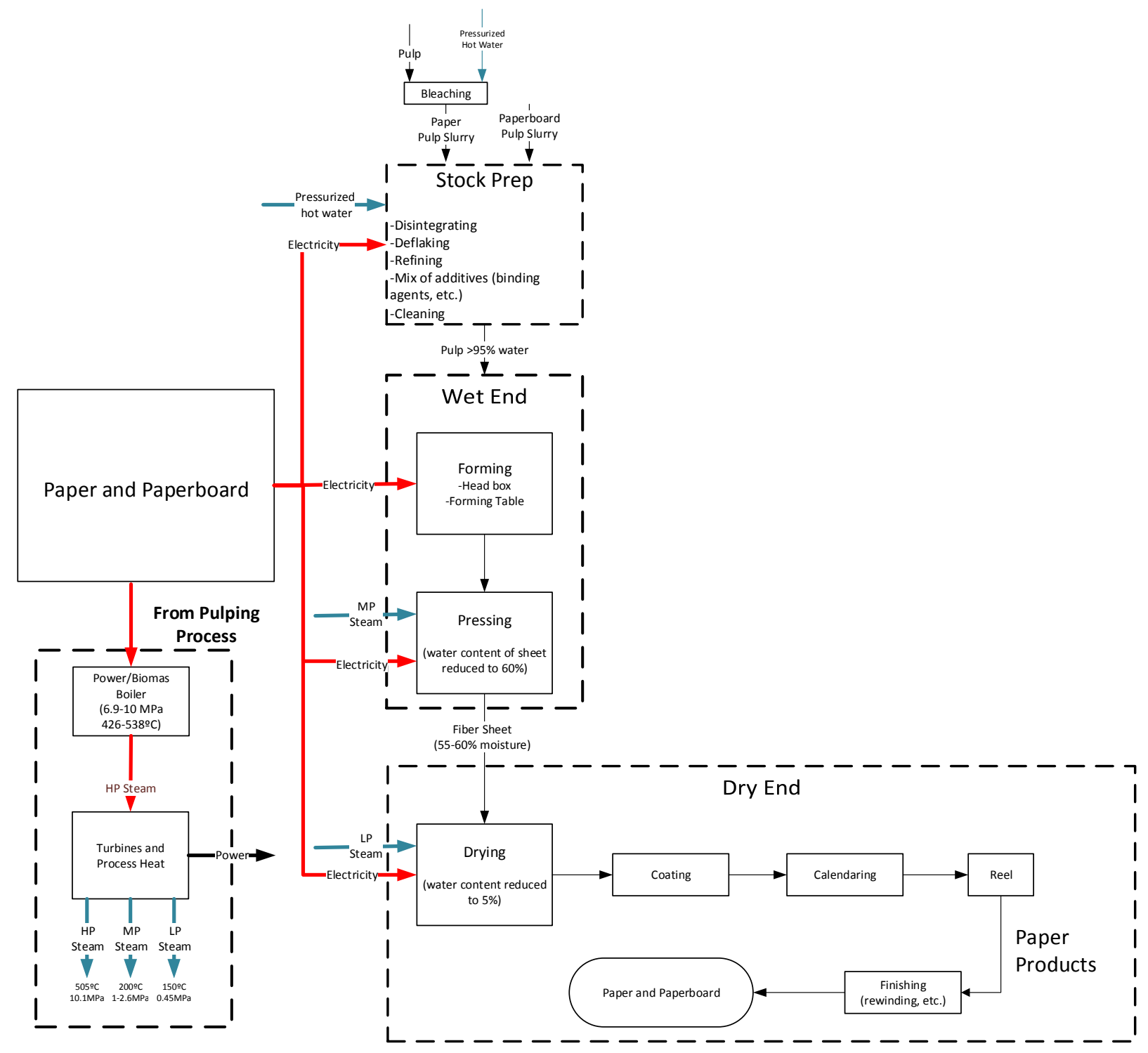

Figure E-2. Paper and paperboard manufacturing process.

\section{E.2 Energy Consumption}

Paper manufacturing in the U.S. is a mature, energy-intensive industry. The U.S. pulp and paper industry is the largest self-generator of electricity in the U.S. manufacturing sector (DOE-EIA 2007). The combination of high steam demand and on-site electricity demand makes combined heat and power an ideal and attractive option for many mills around the country. Overall, refining, screening, forming, pressing, and finishing operations rely mainly on electricity, whereas drying operations require large amounts of steam. Figure C-3shows that drying is the most energy intensive step associated with paper manufacturing processes. Figure C-4 shows that natural gas, purchased electricity, and coal are the major energy related greenhouse gas (GHG) emission sources for U.S. paper mills. The estimates in Figure C-4 do not include GHG emissions arising from non-energy related sources (such as lime kiln chemical reactions and methane emissions from mill wastewater treatment). Tables C-1 and C-2 summarize the details on energy consumption and heat usage for the paper and paperboard manufacturing in U.S. 


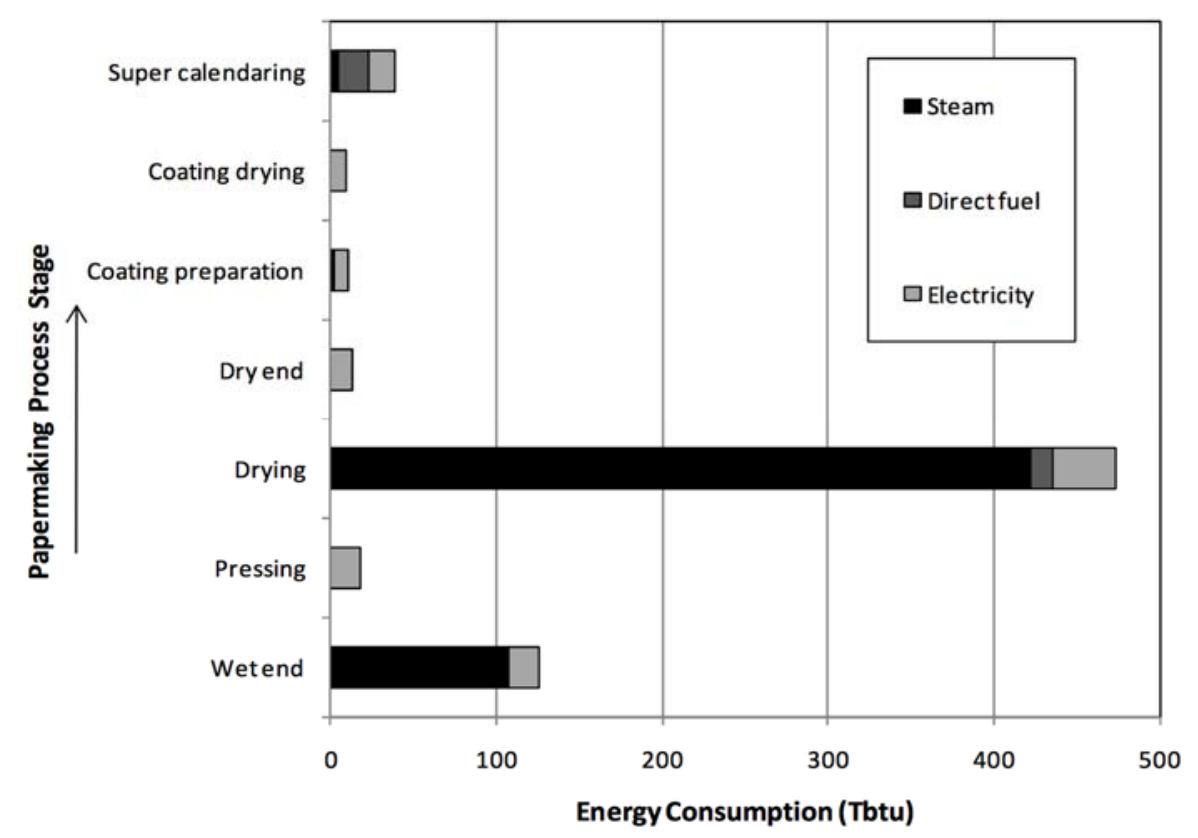

Figure E-3. Energy use of U.S. paper manufacturing by end use energy type in 2002 (DOE-EIA 2007, Jacobs and IPST 2006).

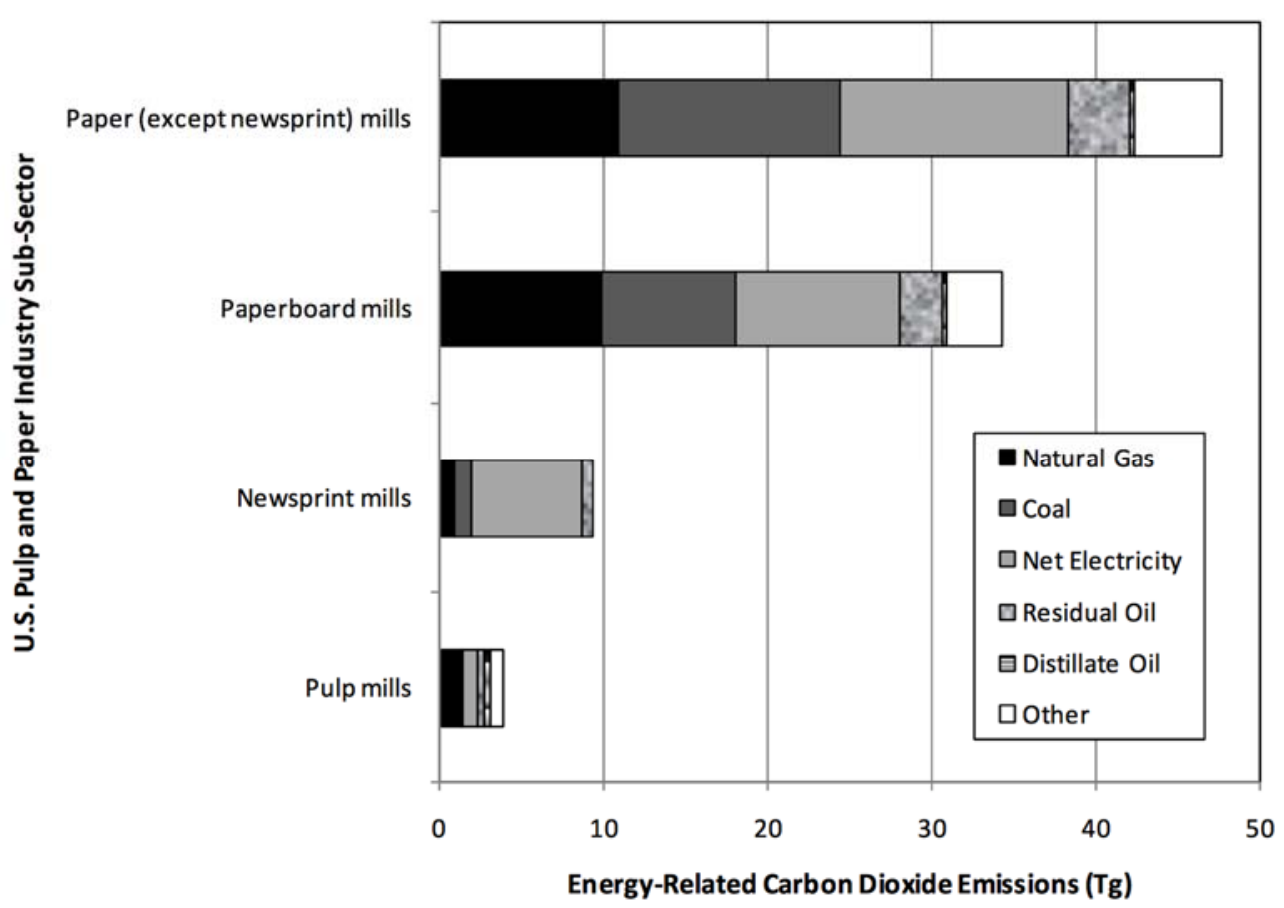

Figure E-4. Estimated energy-related GHG emissions of the U.S. paper industry in 2002 (DOE-EIA 2007). 
Table E-1. Production comparison for paper and paperboard for $2002^{*}$ and 2006 in the U.S.

\begin{tabular}{|l|cr|cc|}
\hline & \multicolumn{2}{|c|}{ Production Based on 2002 } & \multicolumn{2}{c|}{ Production Based on 2006 } \\
\hline & Facilities & $\begin{array}{c}\text { Production } \\
\text { (tonnes/day) }\end{array}$ & Facilities & $\begin{array}{r}\text { Production } \\
\text { (tonnes/day) }\end{array}$ \\
Paper & 307 & $1.07 \mathrm{E}+05$ & 325 & $1.04 \mathrm{E}+05$ \\
Paperboard & 200 & $1.21 \mathrm{E}+05$ & 205 & $1.25 \mathrm{E}+05$ \\
Total & 507 & $2.31 \mathrm{E}+05$ & 530 & $2.33 \mathrm{E}+05$ \\
\hline
\end{tabular}

${ }^{*}$ Production averaged between 2000 and 2003 values (U.S. Census Bureau 2011).

Table E-2. Energy consumption of the U.S. paper industry (based on 2002 data, Kramer et al. 2009).

\begin{tabular}{|c|c|c|c|}
\hline & Facilities & $\begin{array}{l}\begin{array}{l}\text { Production } \\
\text { (tonnes/yr) }\end{array} \\
\end{array}$ & $\begin{array}{c}\text { Production } \\
\text { (tonnes/day) }\end{array}$ \\
\hline Paper & 307 & $3.89 \mathrm{E}+07$ & $1.07 \mathrm{E}+05$ \\
\hline Paperboard & 200 & $4.40 \mathrm{E}+07$ & $1.21 \mathrm{E}+05$ \\
\hline Total & 507 & $8.43 \mathrm{E}+07$ & $2.31 \mathrm{E}+05$ \\
\hline \multicolumn{4}{|l|}{ Energy consumption by process } \\
\hline \multicolumn{4}{|l|}{ Wet End (including Stock Prep) } \\
\hline steam (TJ/day) & 315.07 & & \\
\hline electricity (MW) & 602 & & \\
\hline \multicolumn{4}{|l|}{ Pressing } \\
\hline electricity (MW) & 669 & & \\
\hline \multicolumn{4}{|l|}{ Dry End } \\
\hline electricity (MW) & 502 & & \\
\hline \multicolumn{4}{|l|}{ Drying } \\
\hline steam (TJ/day) & 1228 & & \\
\hline fuel (TJ/day) & 31.79 & & \\
\hline electricity (MW) & 1304 & & \\
\hline \multicolumn{4}{|l|}{ Coating Prep } \\
\hline steam (TJ/day) & 8.67 & & \\
\hline electricity (MW) & 301.02 & & \\
\hline \multicolumn{4}{|l|}{ Coating Drying } \\
\hline electricity (MW) & 334.47 & & \\
\hline \multicolumn{4}{|l|}{ Super Calendaring } \\
\hline steam (TJ/day) & 17.34 & & \\
\hline fuel (TJ/day) & 54.92 & & \\
\hline electricity (MW) & 501.71 & & \\
\hline Total Electricity Requirement (MW) & 4214.20 & & \\
\hline Average Electricity Requirement (MW) & 8.31 & & \\
\hline Total Heat Requirement (TJ/day) & 1655.79 & & \\
\hline Average Heat Requirement ( $\mathrm{TJ} /$ day) & 3.27 & & \\
\hline \multicolumn{4}{|l|}{ Water Consumption $* * *$} \\
\hline
\end{tabular}


Avg. Consumption for Paperboard (tonnes/day)

29180.77

Emissions**

$\mathrm{CO}_{2}$ Emissions (tonnes/day)

Paper

47123.29

Paperboard

24657.53

** DOE-EIA 2000, modified for 2002 census data.

*** USGS, 1955, "Water Requirements of Selected Industries," Geological Survey Water-Supply Paper 1330, http://pubs.usgs.gov/wsp/1330a/report.pdf, accessed May 17, 2016 


\section{Appendix F Pulp Process}

The pulp and paper industry consumes a total of $73 \mathrm{GW}_{\mathrm{t}}$ each year. Black liquor, a by-product of pulp, accounts for $36 \%$ of the total energy consumed. There are 114 mills that consume black liquor in the United States. The majority are in the southeast region of the United States (Lasley 2015). This summary is based on a reference pulp mill which uses the Kraft process to make the pulp (AF-Engineering AB 2011). Details of the mill are found in Figure D-2. A summary of the Kraft process is shown in Figure D-1, with detailed information in Tables D-1 and D-2.

Additional references on the Kraft process are provided (Eggeman 2010).

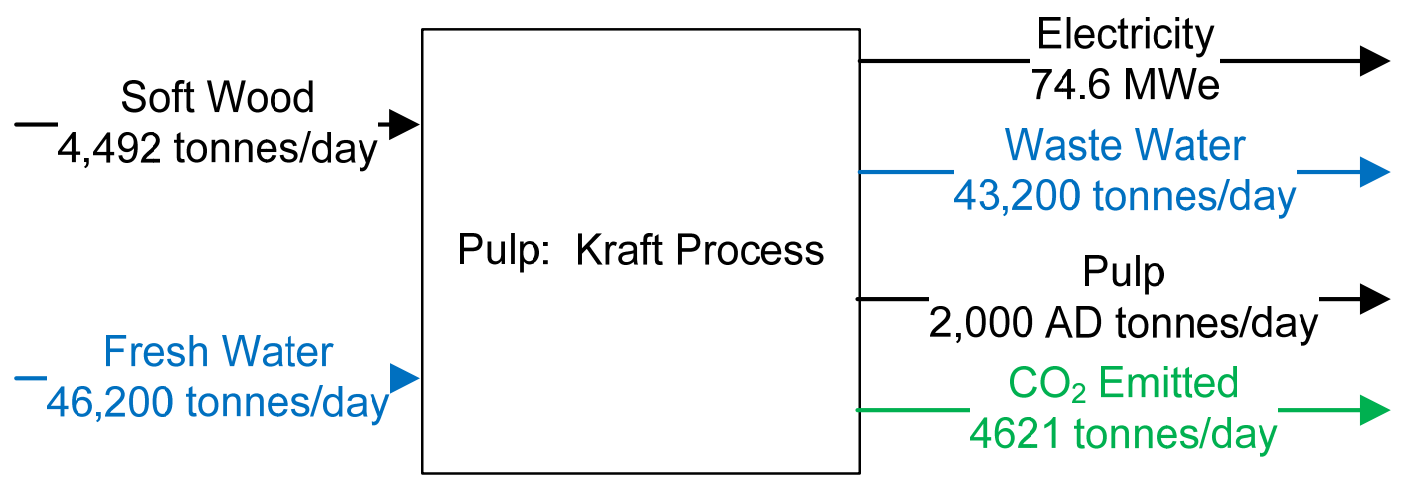

Figure F-1. Summary of pulp process

\section{F.1 Description}

- Wood Yard: The raw wood is debarked in drums. After debarking the logs are cut into chips in a chipper. The bark and waste wood are combusted and used for heat within the lime kiln and the biomass boiler.

- Digester Plant: The wood chips are pre-steamed, soaked, and cooked at $143^{\circ} \mathrm{C}$ with cooking chemicals composed of white liquor (sodium hydroxide and sodium sulfide), some black liquor, and medium pressure steam from the recovery boiler. Black liquor consisting of spent pulping chemicals from the white liquor, dissolved wood and water is formed. A brown stock is formed, which is the primary source of the pulp. Black liquor is removed in a single stage flash tank and sent to the evaporator. The brown stock is washed and bleached.

- Pulp Washing \& Oxygen Delignification: Lignin is removed from the brown stock in two stages using oxidized white liquor as the primary alkali source. Two to three stages of brown stock washing occurs depending on whether the wood source is hard or soft wood.

- Bleaching: Four bleaching stages are used to bleach the brown stock.

- Pulp Drying: The wet pulp passes through screen baskets to remove water and is then dried in a floating web of hot air heated by low pressure steam from the recovery boiler.

- Multi-Effect Evaporator: A six to seven stage multi-effect evaporator is used to remove water from the weak black liquor. Low pressure and high pressure steam from the recovery boiler provides the heat for each stage.

- Recovery and Biomass Boilers: The black liquor is combusted to produce $412 \mathrm{MW}_{\mathrm{t}}$ high pressure steam at $10 \mathrm{MPa}$ and $505^{\circ} \mathrm{C}$ within the recovery boiler. The steam is used to 
produce power and process heat. Bark and waste wood are combusted to produce $35 \mathrm{MW}_{\mathrm{t}}$ of $10 \mathrm{MPa}, 505^{\circ} \mathrm{C}$ steam in the biomass boiler. The steam from this boiler is used to produce power. The molten smelt from the combusted black liquor contains mostly sodium sulfide and sodium carbonate. The smelt is dissolved in water to form green liquor which is sent to the causticizing plant.

- Turbines and Process Heat: Power is produced by expanding high pressure steam. Intermediate pressure steam and medium pressure steam are extracted from within the turbine. Low pressure steam from the exit of the back-pressure turbine is also used as process heat. High pressure steam not used for process heat is expanded through a condensing turbine to maximize power production.

- Causticizing Plant: Within the causticizing plant, the green liquor is filtered and the dregs are washed and sent to the landfill. The green liquor is reacted with lime to produce white liquor, which is sent to the digester plant. The precipitated calcium carbonate (lime mud) is sent to the lime kiln.

- Lime Kiln: Lime mud from the causticizing plant is heated to $800^{\circ} \mathrm{C}$ to produce lime (calcium oxide) for the causticizing plant. The heat is produced from combusting bark and waste wood. 


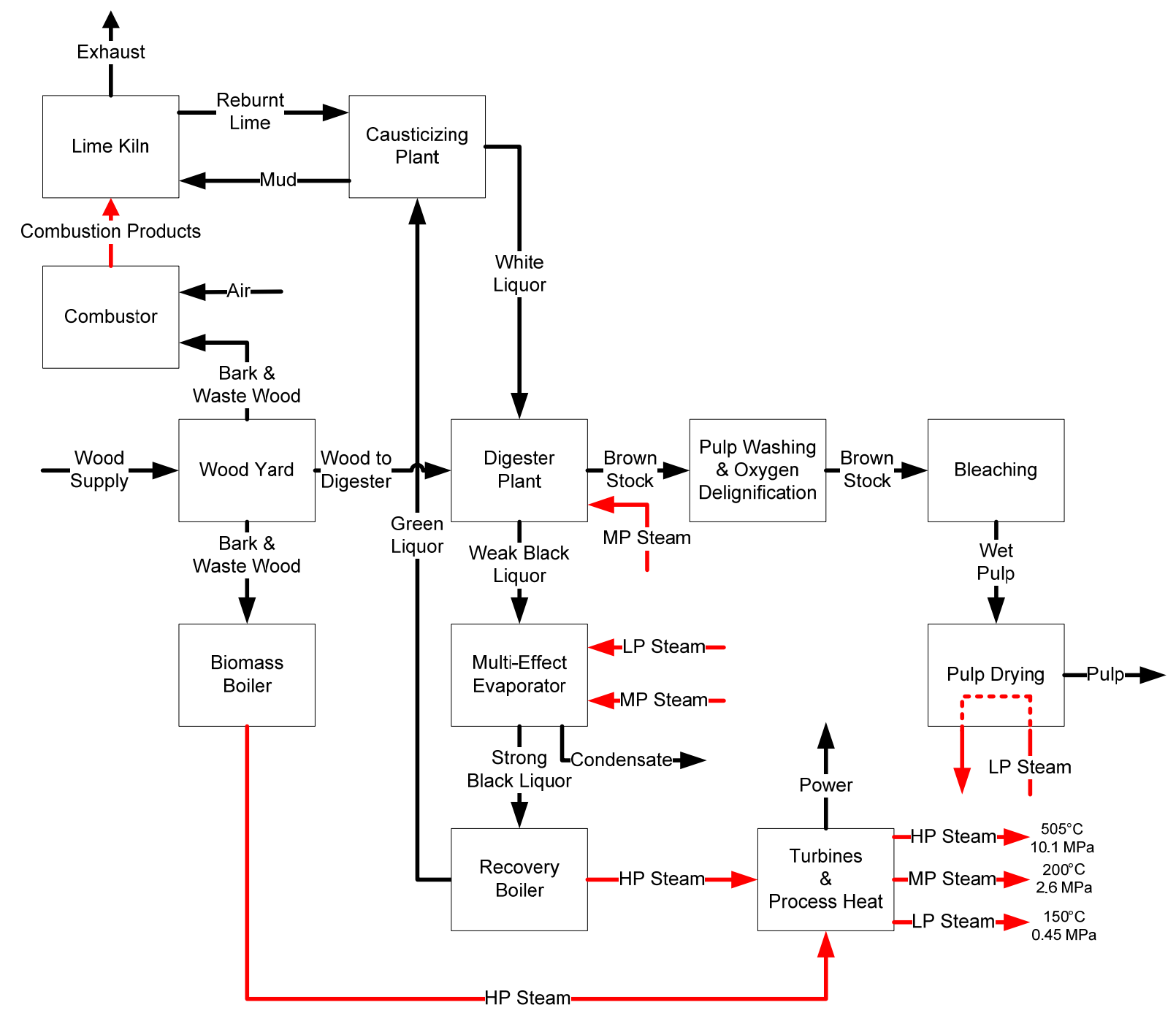

Figure F-2. Schematic of pulp making Kraft process 
Table F-1. Pulp Process Results

Pulp Process Results

\begin{tabular}{|c|c|}
\hline \multicolumn{2}{|l|}{ Inputs } \\
\hline Wood to digester (tonnes/day) & 4072 \\
\hline Bark and wood waste & 420 \\
\hline \multicolumn{2}{|l|}{ Outputs } \\
\hline Pulp (air dried tonnes/day) & 2000 \\
\hline Power (MWe) & 74.6 \\
\hline \multicolumn{2}{|l|}{ Intermediate Streams } \\
\hline White liquor (m³/day) & 7,541 \\
\hline Strong black liquor (tonnes/day), $80 \%$ dry & 3,477 \\
\hline \multicolumn{2}{|l|}{ Utility Summary } \\
\hline Total Power Sold $\left(\mathrm{MW}_{\mathrm{e}}\right)$ & 74.6 \\
\hline Wood yard & -3.8 \\
\hline Digester & -3.7 \\
\hline Washing and screening & -5.0 \\
\hline Oxygen stage & -5.0 \\
\hline Bleaching & -6.7 \\
\hline Final Screening & -3.8 \\
\hline Pulp machine & -10.4 \\
\hline Evaporation & -2.3 \\
\hline Causticizing & -5.0 \\
\hline Boiler house & -6.7 \\
\hline Cooling Tower & -2.1 \\
\hline Raw water treatment $\&$ distribution & -1.4 \\
\hline Effluent treatment & -1.4 \\
\hline Chemical preparation & -0.8 \\
\hline Miscellaneous, losses & -2.3 \\
\hline Total Power for Kraft Process & -60.4 \\
\hline Total Power Produced & 135 \\
\hline \multicolumn{2}{|l|}{ Water (tonnes/day) } \\
\hline Fresh water in & 46,200 \\
\hline Waste water & 43,200 \\
\hline \multicolumn{2}{|l|}{$\mathrm{CO}_{2}$ Emissions } \\
\hline Emitted (tonnes/day $\mathrm{CO}_{2}$ ) & 4,621 \\
\hline
\end{tabular}


Table F-2. Heat addition to Kraft pulp process

Heat Usage in Pulp Process

\begin{tabular}{|c|c|c|c|}
\hline & $\begin{array}{c}\text { Heat } \\
\text { (terajoules/day) }\end{array}$ & $\begin{array}{c}\text { Temperature In } \\
\left({ }^{\circ} \mathrm{C}\right)\end{array}$ & $\begin{array}{c}\text { Temperature } \\
\text { Out }\left({ }^{\circ} \mathrm{C}\right)\end{array}$ \\
\hline \multicolumn{4}{|l|}{ Heat from Combustion Products } \\
\hline Heat to lime kiln & 2.83 & $>800$ & \\
\hline \multicolumn{4}{|l|}{ Heat from Steam } \\
\hline \multicolumn{4}{|l|}{ High pressure steam (10.1 MPa) } \\
\hline Back pressure turbine & 6.24 & 505 & 150 \\
\hline Condensing turbine & 16.04 & 505 & 35 \\
\hline Blow down recover boiler & 0.26 & 505 & \\
\hline Blow down biomass boiler & 0.02 & 505 & \\
\hline \multicolumn{4}{|l|}{ Medium pressure 1 steam (2.6 MPa) } \\
\hline Soot blowing recovery boiler & 2.05 & 275 & \\
\hline Soot blowing power boiler & 0.03 & 275 & \\
\hline \multicolumn{4}{|l|}{ Medium pressure 2 steam (1 MPa) } \\
\hline Digester & 3.09 & 200 & 170 \\
\hline Bleaching & 0.44 & 200 & 180 \\
\hline Oxygen stage & 0.16 & 200 & 100 \\
\hline Multi-effect evaporator & 0.84 & 200 & 140 \\
\hline Chemical preparation & 0.05 & 200 & 100 \\
\hline Miscellaneous losses & 0.29 & 200 & 100 \\
\hline \multicolumn{4}{|l|}{ Low pressure steam $(0.45 \mathrm{MPa})$} \\
\hline Pulp machine & 4.15 & 150 & 100 \\
\hline Multi-effect evaporator & 6.15 & 150 & 140 \\
\hline Chemical preparation & 0.15 & 150 & 100 \\
\hline Miscellaneous losses & 0.37 & 150 & 100 \\
\hline
\end{tabular}

\section{F.2 References}

AF-Engineering AB. 2011. Energy consumption in the pulp and paper industry - Model mills 2010: Bleached kraft market pulp mill, AForsk Reference: 09-163. Stockholm: AF-Engineering AB. 
Eggeman, Tim. 2010. "Pulp." In Kirk-Othmer Encyclopedia of Chemical Technolgy, 1-47. John Wiley \& Sons, Inc.

Lasley, Trevin. 2015. Hybrid Enegy Systems in Manufacturing-Pulp and Paper Industry. Idaho Falls: Idaho National Laboratory. 


\section{Appendix G All Other Basic Organic Chemical Manufacturing (Methanol Production)}

As of 2013, North America's installed capacity for methanol production was 1.8 million tonnes/year. By 2020, this capacity is expected to increase to 6.5 million tonnes/year. With the decrease in the price of natural gas, methanol has become a popular means to make liquid fuels from natural gas. Methanol is used as an octane rating booster when blended with gasoline. Methanol can replace naphtha in the production of olefins (Morris, 2013). The data used for this section is based on work done at Idaho National Laboratory (R. A. Wood 2010).

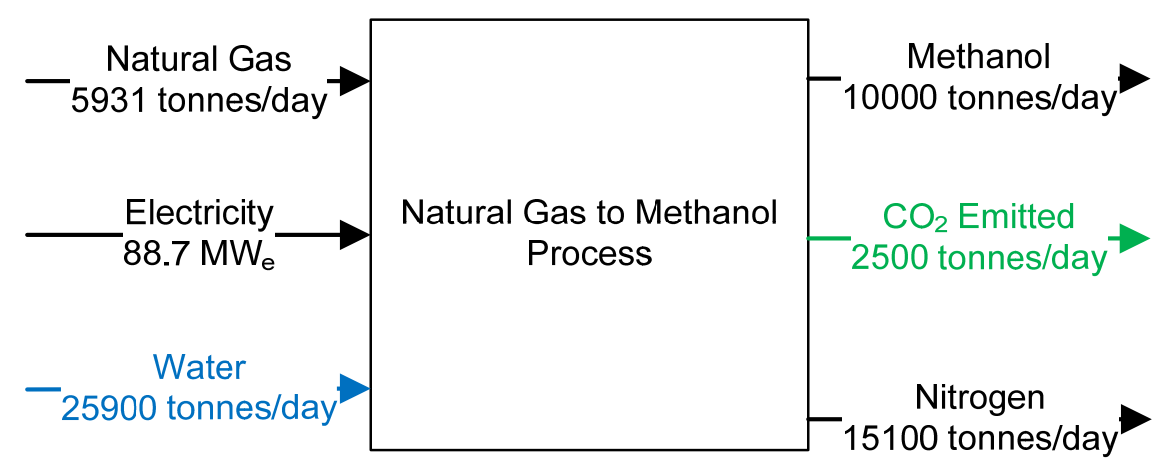

Figure G-1. Summary of natural gas to methanol

\section{G.1 Description}

A schematic of the methanol process is shown in Figure G-2.

- Natural Gas Reforming: Two-step reforming was used for the data in Figure E-1 and Table E-1. The steam-to-carbon inlet molar ratio was set to 1.80 and the exit temperatures of the primary and secondary reformers were set to $739^{\circ} \mathrm{C}$, and $1,038^{\circ} \mathrm{C}$. Natural gas is split into two streams. Of the total natural gas flow, $10.5 \%$ is burned to provide heat for the primary reformer. The remaining $89.5 \%$ of the natural gas flow is compressed to $4.24 \mathrm{MPa}$ and then preheated to $177^{\circ} \mathrm{C}$ and saturated with hot water. After saturation, the gas is further heated to $350^{\circ} \mathrm{C}$ and mixed with a small amount of hydrogen. Sulfur is removed from the gas and then mixed with steam to achieve the desired steam-to-carbon molar ratio of 1.8. Because the resulting natural gas/steam mixture is preheated to only $538^{\circ} \mathrm{C}$, a preformer is not included in this flowsheet. The natural gas/steam mixture is fed to the primary reformer where methane is converted over a catalyst to $\mathrm{CO}, \mathrm{H}_{2}$, and $\mathrm{CO}_{2}$. Methane conversion in this reactor is approximately $25 \%$. A separate feed of the natural gas is mixed with fuel gas and burned to provide heat for the endothermic reforming reactions. The hot offgas from the reformer is exchanged with inlet syngas, water, and steam to provide preheat for these streams. The effluent from the primary reformer and oxygen are fed to an autothermal reformer where conversion of the remaining methane to syngas is accomplished. The oxygen-to-carbon molar ratio is set at 0.41 , which results in an exit temperature of $1038^{\circ} \mathrm{C}$. The hot syngas is cooled by exchange with boiler feed water to create steam, followed by condensation of the water from the syngas. The resulting syngas has a $\mathrm{H}_{2} / \mathrm{CO}$ ratio of 3.1 and contains $7.2 \mathrm{~mol} \%$ $\mathrm{CO}_{2}$ and $0.9 \mathrm{~mol}_{0} \mathrm{CH}_{4}$.

- Air Separation: Oxygen is produced through a standard cryogenic air separation unit, which utilizes two distillation columns and extensive heat exchange in a cold box. The 
oxygen product is used for gasification. The nitrogen co-product from the ASU can be used for transport and as inert gas to be used throughout the plant. The waste stream from the air separation unit is an $\mathrm{O}_{2}$-enriched air stream.

- Syngas Cooling: The hot syngas makes steam within a boiler. The steam is used within the process.

- Compression: The syngas is compressed to 7.5 MPa prior to the methanol reactor.

- Methanol Synthesis: Syngas feeding the methanol synthesis unit has been previously adjusted to achieve a $\left(\mathrm{H}_{2}-\mathrm{CO}_{2}\right) /\left(\mathrm{CO}+\mathrm{CO}_{2}\right)$ molar ratio of 2.10. This results in a $\mathrm{H}_{2} / \mathrm{CO}$ molar ratio for the feed gas of 2.45. Incoming feed gas is compressed to $7.5 \mathrm{MPa}$, followed by heating via recuperation to $217^{\circ} \mathrm{C}$ prior to introduction into the methanol conversion reactor. Methanol is formed via the following reactions:

$$
\begin{aligned}
& \mathrm{CO}+\mathrm{H}_{2} \mathrm{O} \rightarrow \mathrm{H}_{2}+\mathrm{CO}_{2} \\
& \mathrm{CO}_{2}+3 \mathrm{H}_{2} \rightarrow \mathrm{CH}_{3} \mathrm{OH}+\mathrm{H}_{2} \mathrm{O} .
\end{aligned}
$$

Which result in the net reaction for $\mathrm{CO}$ to methanol:

$$
\mathrm{CO}+2 \mathrm{H}_{2} \rightarrow \mathrm{CH}_{3} \mathrm{OH}
$$

Methanol and unreacted syngas exiting the reactor are cooled by recuperation with the incoming feed gas, followed by condensation and separation of the liquid methanol product. Unreacted gas is recompressed, mixed with fresh incoming syngas, and fed back to the methanol synthesis reactor. A purge on the unreacted gas stream is set to limit buildup of inert gas within the synthesis loop; the molar recycle ratio is currently set at 4.0:1. These conditions result in a reactor inlet $\mathrm{CO}_{2}$ concentration of $1 \mathrm{~mol} \%$ and a methanol concentration in the reactor exit stream of $7.6 \mathrm{~mol} \%$. Condensed methanol product is purified in a distillation column to remove light gases prior to storage in the methanol intermediate product tank. The purge gases are used as fuel gas for power production in the plant.

Table G-1 and Table G-2 list relevant information about the methanol feedstocks, products, emissions, and heat and power usage. 


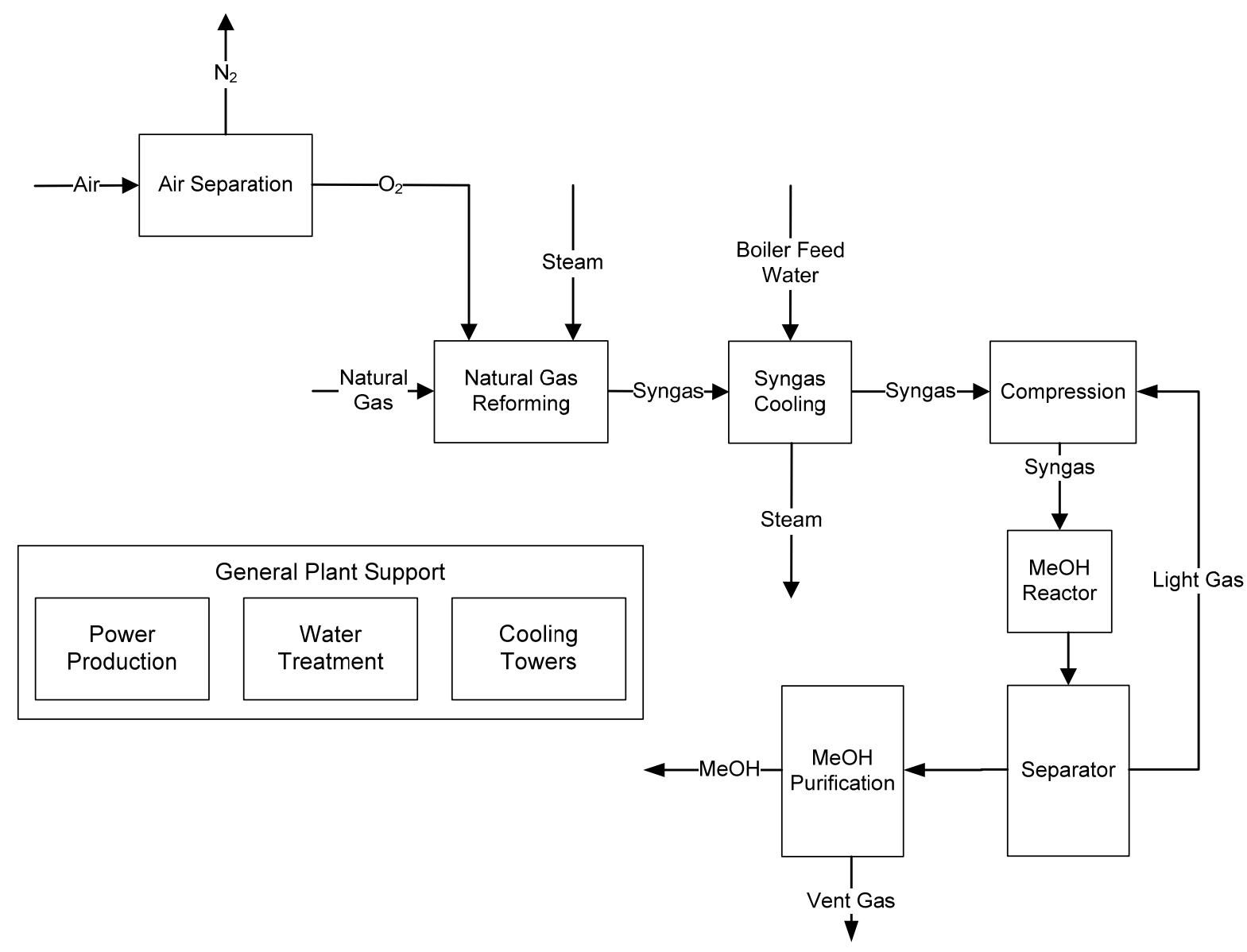

Figure G-2. Schematic of process for making methanol

Table G-1. Inputs, products, utility, and emissions of natural gas to methanol process

Natural Gas to Methanol Process

\begin{tabular}{lc}
\hline Inputs & \\
Natural Gas Feed Rate (tonnes/day) & 5931 \\
\hline Products & 1000 \\
Methanol (tonnes/day) & 15100 \\
Nitrogen (tonnes/day) & \\
\hline Utility Summary & -88.7 \\
Total Power (MW) & -13.8 \\
Natural Gas Reforming & -75.1 \\
Air Separation & 59.8 \\
Power Island & -49.1 \\
Methanol Plant &
\end{tabular}




\begin{tabular}{cc}
\hline \multicolumn{2}{c}{ Natural Gas to Methanol Process } \\
\hline Cooling Towers & -2.77 \\
Water Treatment & -7.69 \\
Total Water Balance (tonnes/day) & $-25,900$ \\
\hline $\mathrm{CO}_{2}$ Emissions & 2500 \\
\hline Emitted (tonnes/day $\mathrm{CO}_{2}$ ) &
\end{tabular}

Table G-2. Heat addition from natural gas

\begin{tabular}{lrrr}
\hline Location & $\begin{array}{c}\text { Heat Duty } \\
(\mathrm{TJ} / \text { day) }\end{array}$ & $\begin{array}{c}\text { Inlet } \\
\text { Temperature }\left({ }^{\circ} \mathrm{C}\right)\end{array}$ & $\begin{array}{c}\text { Outlet } \\
\text { Temperature }\left({ }^{\circ} \mathrm{C}\right)\end{array}$ \\
\hline Primary reformer & 30.259 & 538 & 739 \\
Preheat steam/air into secondary reformer & 6.989 & 859 & 583 \\
Preheat steam/NG into primary reformer & 3.469 & 583 & 439 \\
Preheat steam before mix with NG & 3.798 & 439 & 276 \\
Preheat NG before mix with steam & 1.266 & 276 & 219 \\
NG preheat & 0.253 & 219 & 208 \\
Steam preheat & 0.279 & 208 & 196 \\
Process preheat & 1.291 & 196 & 138
\end{tabular}

\section{G.2 References}

Morris, Gregory DL. 2013. The American Oil \& Gas Reporter: U.S. Methanol on the Comeback. April. Accessed September 12, 2016. http://www.aogr.com/web-exclusives/exclusive-story/u.s.-methanol-onthe-comeback.

Wood, R. A. 2010. Nuclear-Integrated Methanol-to Gasoline Production Analysis, TEV-667 Rev. 2. Idaho Falls: Idaho National Laboratory. 


\section{Appendix H Ethyl Alcohol Production within Biorefinery}

In 2015, nearly 50 billion liters of distilled alcohol were produced within the United States for beverage consumption, and 56 billion liters of ethanol fuel was produced (U.S. Department of the Treasury: Alcohol and Tobacco Tax Trade Bureau 2016, U.S. Energy Information Administration 2016). Ethanol may be produced through fermentation of biomass or either direct or indirect hydration of ethylene (Eggeman 2010). The beverage industry uses the fermentation process. An ethyl alcohol production plant process model developed by the National Renewable Energy Laboratory was used to estimate the heat usage and greenhouse gas emissions for a fermentation process (Humbird, et al. 2011). Figure J-1 indicates the overall material and energy flows for the process. The heat input is almost exclusively generated from biogas and non-usable solids from the biomass feedstock. In this study $20 \%$ by weight moisture content was assumed as part of the feedstock composition. Figure H-2 is a schematic of the process with a description of each sub processes provided in section F.1.

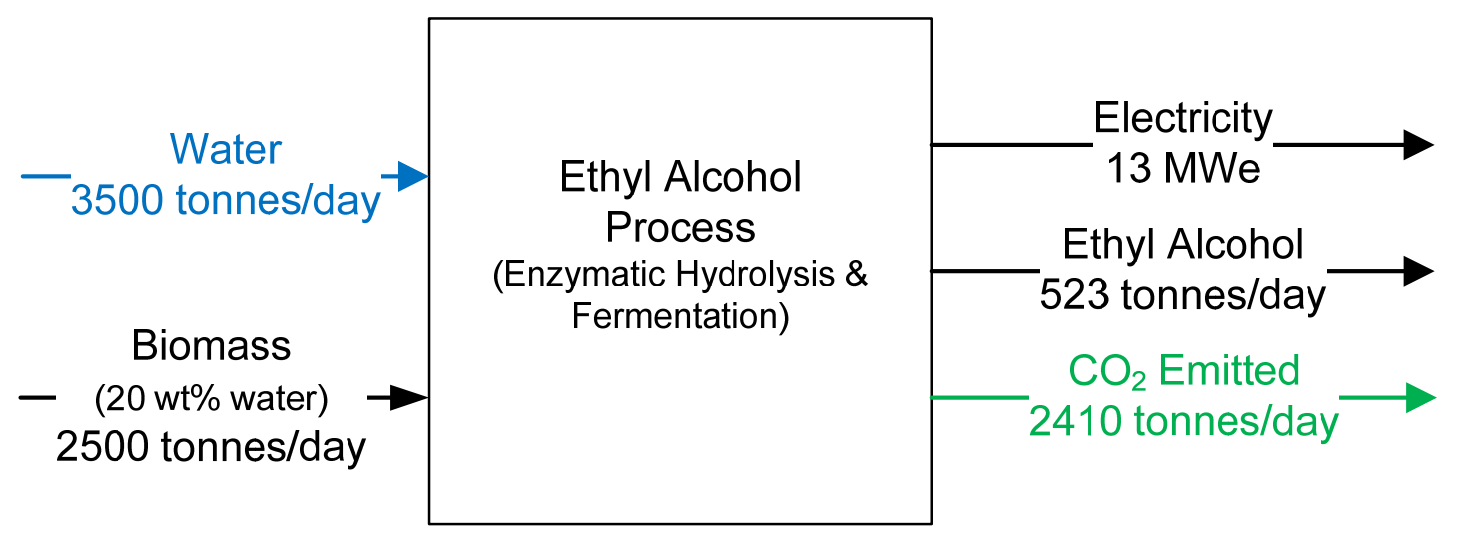

Figure H-1. Summary of ethyl alcohol process

\section{H.1 Description}

- Feed Handling: The raw feedstock is stored at a central depot where it is preprocessed and homogenized. The biorefinery receives a feedstock with known uniform-format specifications such as bulk density, size distribution, and moisture content.

- Pretreatment \& Conditioning: Using hydrolysis reactions, the hemicellulose carbohydrates within the feedstock are converted to soluble sugars. The hydrolysis reactions are catalyzed using dilute sulfuric acid and heat from steam. After the pretreatment, the hydrolysate slurry is flash cooled, vaporizing large amounts of water and some acetic acid and furfural. The vapor is condensed and the condensate is sent to the wastewater treatment plant. Ammonia is added to the hydrolysate slurry to raise its $\mathrm{pH}$ from 1 to 5-6 for the enzymatic hydrolysis process. Pretreatment reactor temperature and pressure are $158^{\circ} \mathrm{C}$ and $0.56 \mathrm{MPa}$. The residence time in the reactor is 5 minutes.

- Enzymatic Hydrolysis \& Fermentation: During this process the cellulose is converted to glucose using cellulose enzymes. A mixture of enzymes breaks down the cellulose fibers into glucose monomers. During pretreatment, the glucose and other sugars are fermented to ethanol. Enzymatic hydrolysis occurs while the slurry is at the higher temperature and pressure of the pretreatment process. Once the conversion of cellulose to glucose is completed, the slurry is cooled to fermentation temperatures and combined with a fermenting 
microorganism called the ethanologen. The viscosity of the slurry drops and is pumped to several parallel bioreactors. Hydrolysis continues within these vessels until complete, after which the slurry is cooled and the ethanologen is added. The fermented broth is emptied into a storage tank before being sent to the distillation process. The enzymatic hydrolysis process runs at $48^{\circ} \mathrm{C}$ and has a residence time of 3.5 days. The fermentation process runs at $32^{\circ} \mathrm{C}$ and has a residence time of 1.5 days.

- Cellulase Enzyme Production: Cellulase is a mixture of enzymes (catalytic proteins) that includes endoglucanases which attack cellulose fiber, exoglucanases which break down the ends of highly crystalline cellulose fibers and $\beta$-glucosidase which hydrolyzes small cellulose fragments to glucose. The cellulase is produced onsite with ethanol using a slipstream of the hydrolysate slurry from pretreatment.

- Distillation, Dehydration, and Solids Separation: Distillation and molecular sieve adsorption are used to recover the ethanol from the fermented broth (beer) to produce $99.5 \%$ ethanol. Two columns are used: the beer column removes the dissolved $\mathrm{CO}_{2}$ and most of the water and the rectification column concentrates the ethanol. The ethanol exits the rectification column to remove additional water using molecular sieve adsorption. During the regeneration of the adsorption columns, a low purity $(70 \mathrm{wt} \%)$ ethanol stream is created and recycled to the rectification column for recovery. The overhead stream of the beer column and fermentation vents are fed to a water scrubber to recover almost all of the ethanol. The beer column bottoms is made of unconverted insoluble and dissolved solids. The water is removed from these solids, which are combusted. The water is sent to wastewater treatment. Low pressure heat (0.96 MPa steam) is supplied to the reboilers of the beer and rectifier columns.

- Wastewater Treatment: To reduce makeup water, the vapor flashed from pretreatment, boiler blowdown water, cooling tower blowdown water, and the pressed stillage water streams are mixed and processed by anaerobic and aerobic digestion to remove the organic materials within the waste water. The resulting water is reused in the process and the remaining sludge is burned in the combustor. Methane is also produced during the process which is combusted. The process requires nitrification to handle the ammonia that will be produced. Reverse osmosis is used to remove the brine from the treated water. The brine is waste.

- Combustor, Boiler, and Turbogenerator: Various organic by-product streams are combusted to produce power and steam. These streams include the lignin, unconverted cellulose and hemicellulose from the feedstock; biogas from anaerobic digestion; and biomass sludge from wastewater treatment. The boiler produces steam at $450^{\circ} \mathrm{C}$ and 6.3 $\mathrm{MPa}$. Process steam is extracted from the power turbines at $1.3 \mathrm{MPa}$ and $268^{\circ} \mathrm{C}$ for the pretreatment reactor and at $0.96 \mathrm{MPa}$ and $164^{\circ} \mathrm{C}$ for the distillation column. More power is generated than is needed for the process; therefore, the excess power is sold.

- Utilities: The utilities that are considered for this bioreactor include cooling water, chilled water, plant and instrument air and process water. Cooling water is used to condense the steam turbine exhaust, condense the refrigerant within the chiller system, cool the pretreatment slurry, cool the ethanol product, cool slurry before fermentation, provide cooling for regeneration of the molecular sieve, condense beer column reflux, and condense flash vapors before wastewater treatment. 


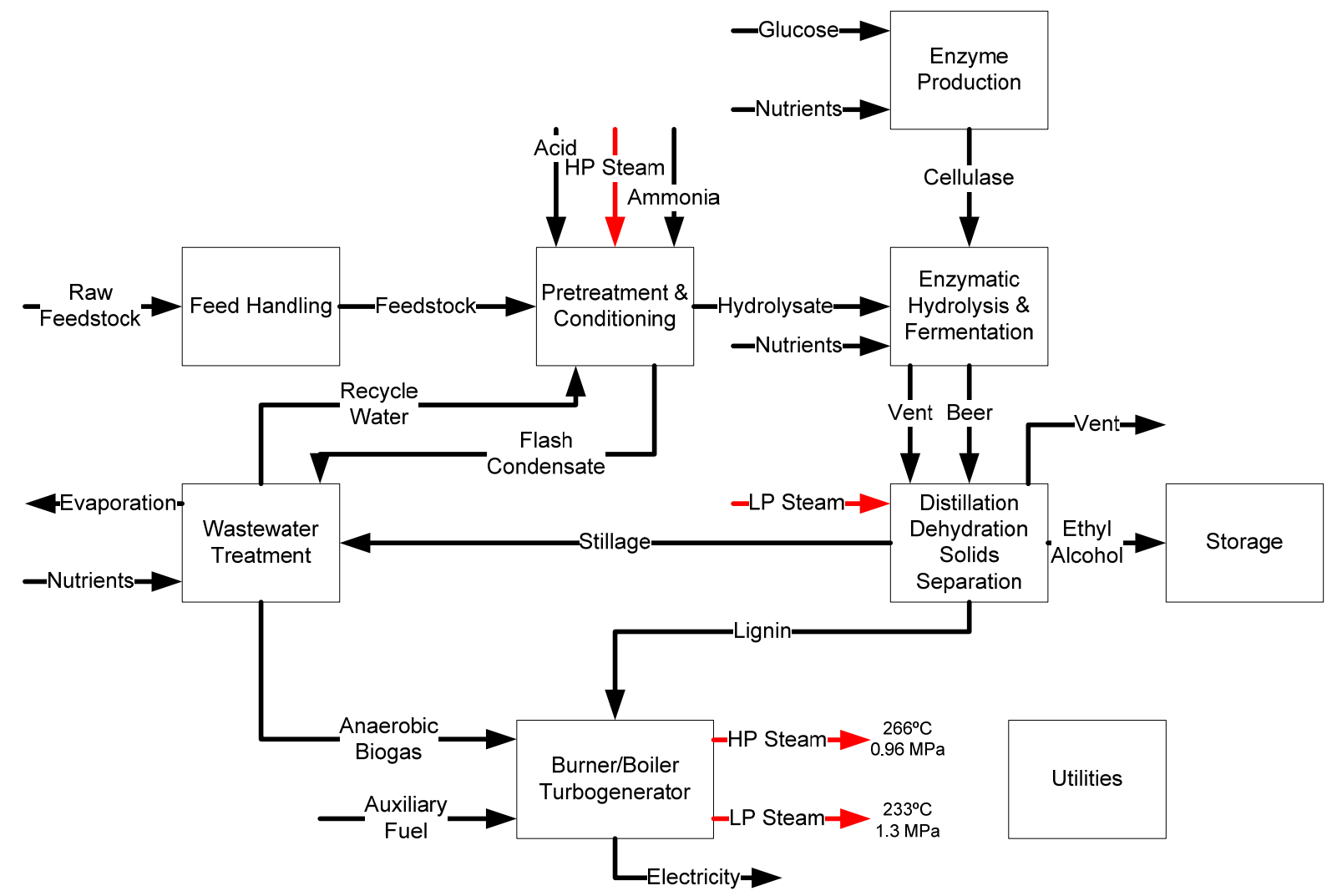

Figure H-2. Schematic of ethanol biorefinery process

Table H-1. Inputs, Products, Utilities, and Emissions of Ethanol Biorefinery Process

\section{Ethyl Alcohol Production}

\section{Inputs}

Biomass Feedstock (tonnes/day)

2500

Outputs

Ethyl Alcohol (tonnes/day)

Utility Summary

Total Power Generated (MW)

Process Power

Power Sold to Grid

Water Input (tonnes/day)

Moisture in feedstock

Water in glucose

Water in raw chemicals

Generated in enzyme production

Generated in wastewater treatment

Generated in combustor

In air intake for enzyme production 
Lignin cake dryer intake $\quad 15$

Wastewater aeration intake 6

Combustor air intake $\quad 105$

Makeup water 134

Water output (tonnes/day)

Water in ethanol product 3

Cooling tower evaporation 3297

Stripped in enzyme aeration $\quad 19$

Scrubber vent 13

Consumed in pretreatmet $\quad 59$

Consumed in hydrolysis process 63

Wastewater evaporation 104

Wastewater brin 119

$\begin{array}{ll}\text { Combustor stack } & 1307\end{array}$

Boiler blowdown 62

Heat (TJ/day)

Steam heat generated in steam generator

$\left(454^{\circ} \mathrm{C} \& 6.07 \mathrm{MPa}\right)$

$\mathrm{HP}$ steam heat $\left(266^{\circ} \mathrm{C} \& 1.31 \mathrm{MPa}\right)$ to

pretreatment 1.73

LP steam heat $\left(233^{\circ} \mathrm{C} \& 0.96 \mathrm{MPa}\right)$ to

fermentation 4.64

$\mathrm{CO}_{2}$ emissions (tonnes/day)

Fermentor emissions $\quad 57$

Scrubber emissions $\quad 498$

Waste water treatment 92

Flue gas $\quad 1762$

Total 2408

\section{H.2 References}

Eggeman, Tim. 2010. "Ethanol." In Kirk-Othmer Encyclopedia of Chemical Technology, 1-35. John Wiley \& Sons.

Humbird, H., R. Davis, L. Tao, C. Kinchin, D. Hsu, A. Aden, P. Schoen, et al. 2011. Process Design and Economics for Biochemical Conversion of Lignocellulosic Biomass to Ethanol, NREL/TP-5100-47764. Denver: National Renewable Energy Laboratory.

U.S. Department of the Treasury: Alcohol and Tobacco Tax Trade Bureau. 2016. 2015-Distilled Spirits Monthly Statistical Releases: December 2015. March 16. Accessed July 14, 2016. https://www.ttb.gov/statistics/2015/201512dsp.pdf. 
U.S. Energy Information Administration. 2016. Monthly Energy Review: Table 10.3 Fuel ethanol overview. June 27. Accessed July

14http://www.eia.gov/totalenergy/data/monthly/pdf/sec10_7.pdf, 2016.

http://www.eia.gov/totalenergy/data/monthly/pdf/sec 10 7.pdf. 
Appendix I Plastics Material and Resin Manufacturing 


\section{Appendix J Petrochemical Manufacturing (Ethylene Production)}

The U.S. production of ethylene is expected to be as high as 1.6 million barrels per day in 2018 . Within the United States, 23 plants are in or will be in existence by 2018. Most of the plants lie along the gulf coast, (U.S. Energy Information Administration 2015). The capacities of the plants range from 20,000 tonnes per year to 1.4 tonnes per year (Petrochemical Construction Map 2015). Polyethylene production consumes $60 \%$ of the ethylene produced. Ethylene oxide, which is used to make ethylene glycol, is the next largest user of ethylene. Ethylene is also used to make vinyl chloride, styrene, and to make chemicals used in detergent alcohols, plasticizer alcohols, vinyl acetate monomer, and industrial ethanol (Eggeman 2010). Figure J-1 and Table $\mathrm{J}-1$ are summaries of estimated data for the production of ethylene using ethane as the feedstock. The size of the plant is nearly 1 million tonnes per year. The carbon dioxide emissions were estimated by combustion of the fuel assuming methane and the difference in carbon between the ethane feedstock and the ethylene product (Zimmerman and Walzi 2012).

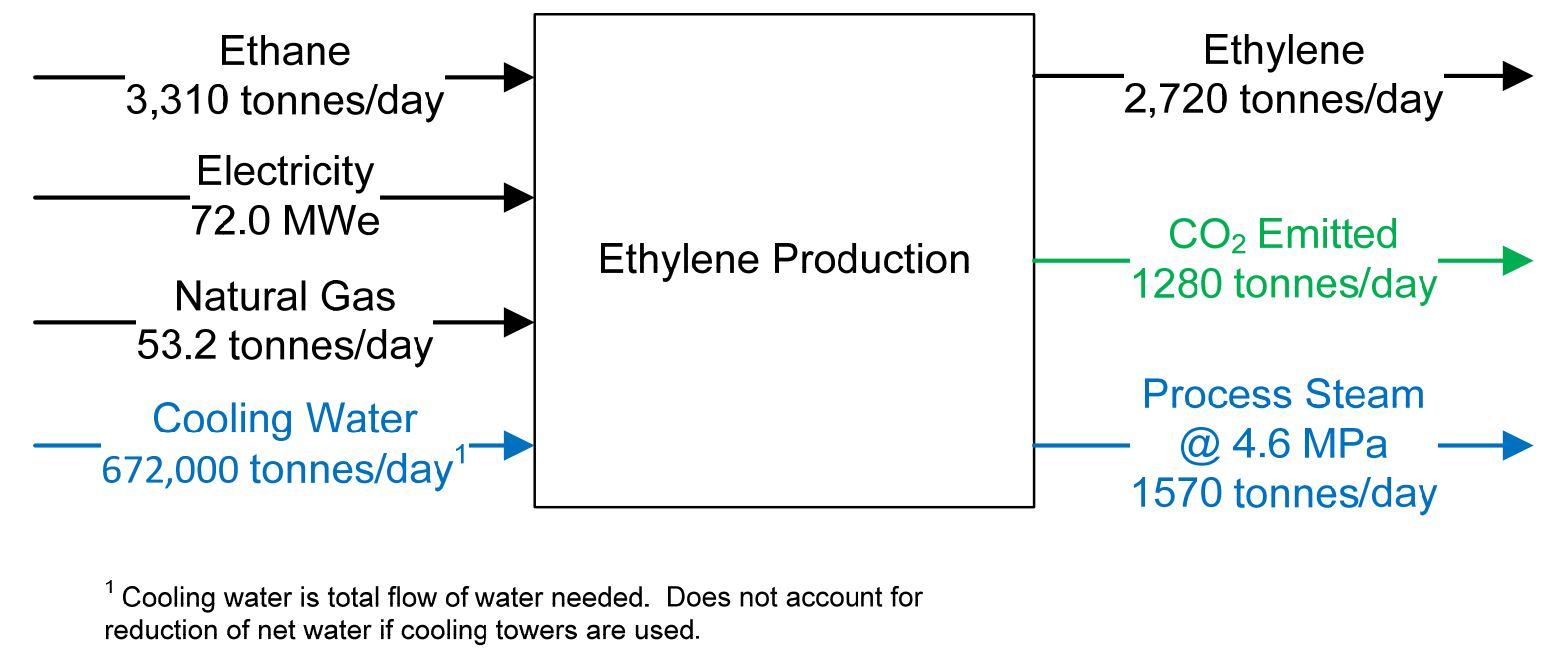

Figure J-1. Summary of ethylene process

\section{J.1 Description}

- Cracking Furnace: The thermal cracking furnace consists of a radiant section, a convection section, and the stack. The feedstock, typically naphtha or liquid petroleum gas, and steam are pre-heated through heat recuperation with the flue gas in the convection section to incipient cracking temperature $\left(500-680^{\circ} \mathrm{C}\right)$. The steam and feedstock are then heated in the radiant section of the furnace in tubes to $750-875^{\circ} \mathrm{C}$ within 0.1 to 0.5 seconds. The hydrocarbons in the feedstock are cracked into smaller molecules: olefins, such as ethylene, and di-olefins. The temperatures needed within the furnaces depend on the feedstock composition. Steam is added to minimize coke formation and to increase the desired olefins. The products leave the radiant tubes at $800-850^{\circ} \mathrm{C}$. The flue gas from the burners is also used to produce high pressure process steam within the convection section. Residence time, partial pressure, temperature, and temperature profiles affect the design of the cracking furnace.

- Transfer Line Exchanger: The cracked products from the furnace are cooled to $550-650^{\circ} \mathrm{C}$ within 0.02 to 0.1 seconds to prevent secondary reactions by using the transfer line 
exchanger. High pressure process steam (6-12 $\mathrm{MPa}$ ) is produced on the cold side of the transfer line exchanger. The transfer line exchanger is usually considered part of the cracking furnace.

- Primary Fractionation: The effluent enters the fractionator where the pyrolysis gasoline is separated from the pyrolysis fuel oil.

- Quench Tower: The quench tower condenses all the steam and most of the pyrolysis gasoline components. The water is separated from the condensed gasoline in quench water drums. The hot quench water is used as a process heat source for the recovery section.

- Compression: The compression of the cracked gas occurs over five stages to a pressure of $3.5 \mathrm{MPa}$.

- Acid Gas Removal: Carbon dioxide and sulfur are removed after the third stage of compression using a caustic solution.

- Charge Gas Dyers: Molecular sieve dryers are used to completely remove the water.

- Demethanizer: The pyrolysis gas is partially condensed at constant pressure using the refrigeration system until hydrogen remains at a vapor state. The condensate first passes through the demethanizer, a distillation column, to produce methane off gas. The demethanizer operates at $0.7 \mathrm{MPa}$ and separates the ethylene and heavier components from the methane.

- Deethanizer: The deethanizer is a tray-type fractionator operating at 2.4 MPa that separates the propylene and heavier components from hydrocarbons. The hydrocarbon overhead is heated to $100^{\circ} \mathrm{C}$ and hydrogen added and passed over a palladium catalyst to produce acetylene which also increases ethylene production as well.

- Ethlyene dryer and fractionator: This column uses a closed heat pump which supplies heat to the reboiler and cooling for the overhead condenser. Ethylene product is produced and the ethane is sent back to the cracking furnace.

- Depropanizer: The condensate stripper bottoms and the deethanizer bottoms are processed in the depropanizer for the separation of lighter hydrocarbons from heavy hydrocarbons.

- Propylene dryer and fractionator: The overhead from the depropanizer is sent to the fractionator to separate the propylene from the propane. The fractionator operates at pressure of 1.8-2.0 MPa. The bottoms product is mainly propane which is sent back to the furnace for cracking.

- Debutanizer: The bottoms of the depropanizer are sent to the debutanizer for the separation of butane from light pyrolysis gasoline. The debutanizer operates at a pressure of 0.4-0.5 $\mathrm{MPa}$. It is a standard fractionator using steam heated reboilers and water cooled condensers. 


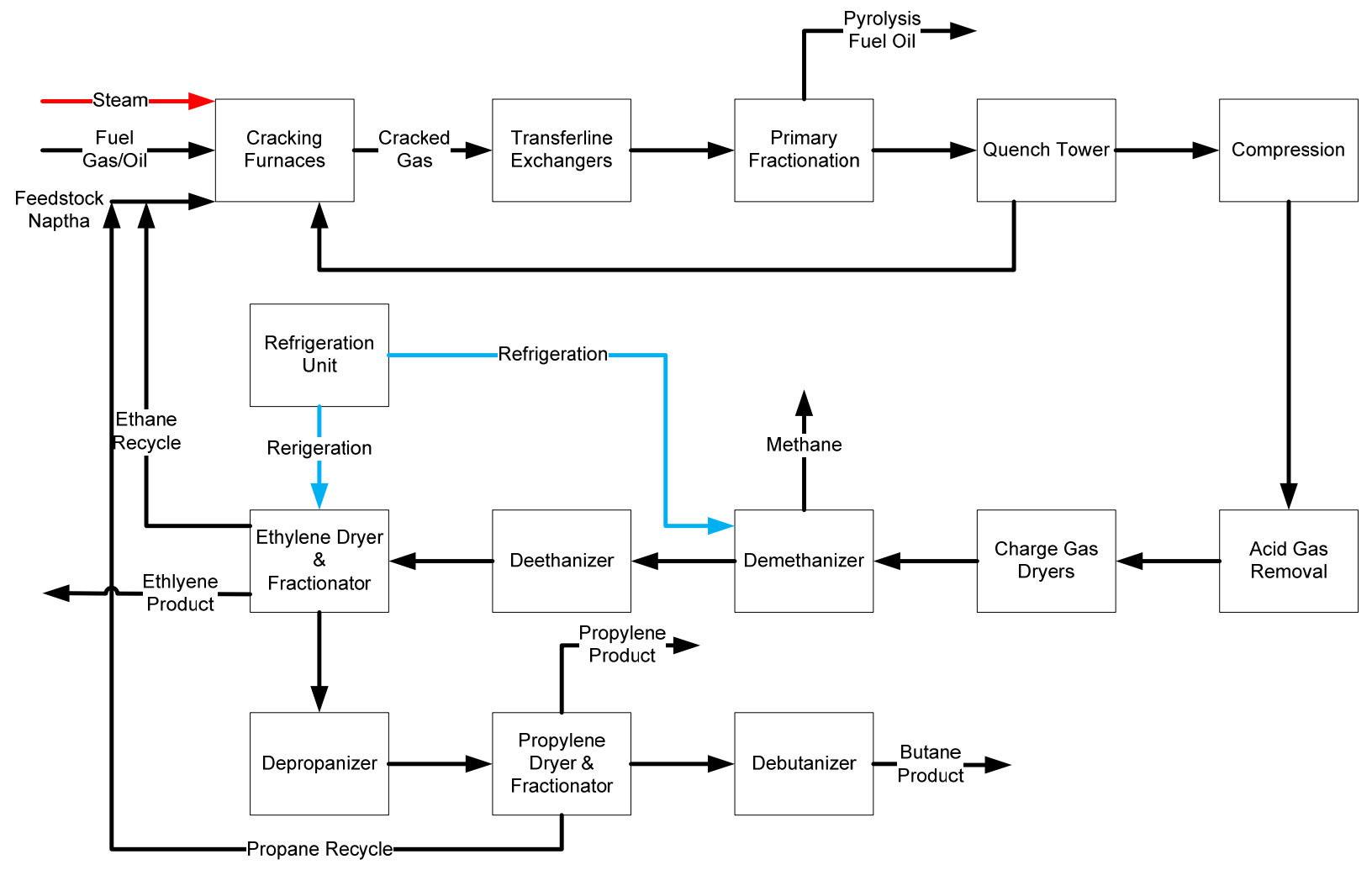

Figure J-2. Schematic of ethylene production process 
Table J-1. Ethylene Process

\begin{tabular}{|c|c|}
\hline \multicolumn{2}{|l|}{ Inputs } \\
\hline Ethane (tonnes/day) & 3310 \\
\hline \multicolumn{2}{|l|}{ Outputs } \\
\hline Ethylene (tonnes/day) & 2720 \\
\hline \multicolumn{2}{|l|}{ Utility Summary } \\
\hline Total Power $\left(\mathrm{MW}_{\mathrm{e}}\right)$ & 72.0 \\
\hline Compressors & 72.0 \\
\hline Other electrical & 0.0035 \\
\hline \multicolumn{2}{|l|}{ Water (tonnes/day) } \\
\hline $\begin{array}{l}\text { Cooling water (assuming no cooling } \\
\text { towers) }\end{array}$ & 672,000 \\
\hline \multicolumn{2}{|l|}{$\mathrm{CO}_{2}$ Emissions (tonnes/day) } \\
\hline Conversion of ethane to ethylene & 1153 \\
\hline From combustion of fuel & 123 \\
\hline Total & 1276 \\
\hline \multicolumn{2}{|l|}{ Heat } \\
\hline Fired duty of cracking furnace (terajoules/day & 53.0 \\
\hline Fuel gas import (terajoules/day) & 2.42 \\
\hline $\begin{array}{l}\text { Super high pressure steam }(6.5 \mathrm{MPa}) \text { generated } \\
\text { and used in process (tonnes/day) }\end{array}$ & 9800 \\
\hline $\begin{array}{l}\text { High pressure steam }(4.6 \mathrm{MPa}) \text { exported } \\
\text { (tonnes/day }\end{array}$ & 1570 \\
\hline
\end{tabular}

\section{J.2 References}

U.S. Energy Information Administration. 2015. Growing U.S. HGL production spurs petrochemical industry developmen. January 29. Accessed July 15, 2016. http://www.eia.gov/todayinenergy/detail.cfm?id=19771.

Eggeman, Tim. 2010. "Ethylene." In Kirk-Othmer Encyclopedia of Chemical Technology, 1-39. John Wiley \& Sons, Inc.

2015. Petrochemical Construction Map. May 14. Accessed July 15, 2016.

https://www.google.com/fusiontables/DataSource?docid=1pjB76IdU4JWMyRQAHZVJpxNAC p7J-9RQK20c81So\#rows:id=1.

Zimmerman, Heinz, and Roland Walzi. 2012. "Ethylene." In Ullmann's Encyclopedia of Industrial Chemistry, 465-529. Weinheim: Wiley-VCH Verlag Gmbh \& Co. KGaA. 


\section{Appendix K Alkalies and Chlorine Manufacturing}

The U.S. Census Bureau refers to the chlorine industry as the "chlor-alkali" (SIC 2812; NAICS 325181) industry (Mansfield et al. 2000). Chlorine and alkali production is heavily dependent on electricity. Production of chlorine occurs through the electrolysis of a salt solution, which results in the production of sodium hydroxide (caustic soda) and hydrogen gas.

$$
2 \mathrm{NaCl}+2 \mathrm{H}_{2} \mathrm{O} \stackrel{\text { Electrical energy }}{\longrightarrow} \mathrm{Cl}_{2}+\mathrm{H}_{2}+2 \mathrm{NaOH}_{(\mathrm{aq})}
$$

There are many processes available with varying energy requirements for chlor-alkali production, but the main processes use diaphragm cell, membrane cell, and mercury cell. Diaphragm cells are the most commonly utilized route for Chlorine and Alkali production in the industry; this process is further discussed. Figure I-1, shows the material and energy flows for a nominal Chlor-Alkali Production Process, the total heat required of $2.7 \mathrm{TJ} /$ day, is assumed to be met by natural gas.

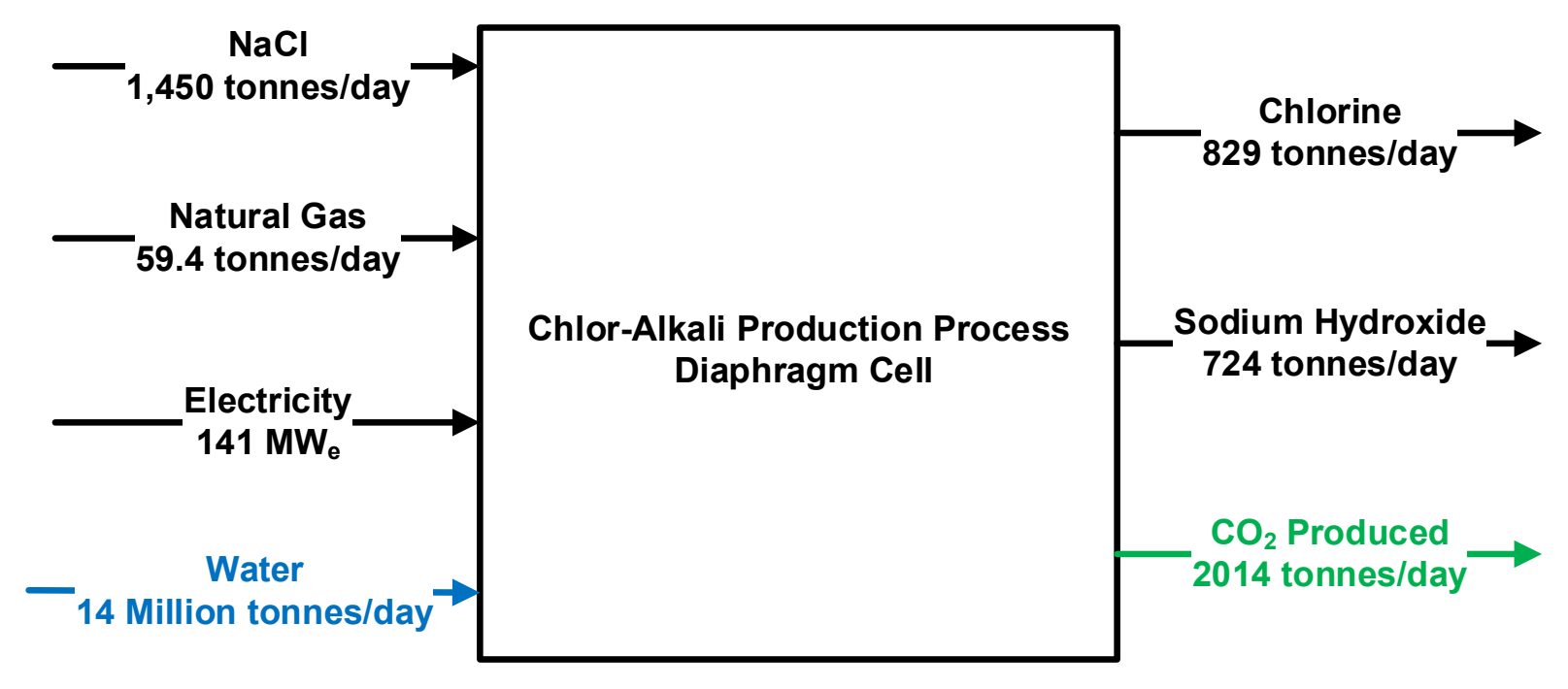

Figure K-1. Material and energy flows for a nominal chlorine-alkali plant

\section{K.1 Process Flow}

Electrolysis of the brine is the primary method used for chlorine production. Similarities exist across the cells used for electrolysis. The main distinguishing characteristic is the manner by which the electrolysis products are prevented from mixing (Mansfield et al. 2000). The process flow diagram is shown in detail in Figure I-2 and the main processes are described as follows:

- Salt Mining: Brine is produced from mining of natural deposits or seawater (via solar evaporation).

- Brine Purification, Filtration, and Heating: Seawater sources contain impurities so the brine (mixture of salt $\mathrm{NaCl}$ and water) goes through purification and filtration process for removal of the impurities and the $\mathrm{pH}$ value is adjusted to 10.5 - 11. Further, brine is heated to between $90-105^{\circ} \mathrm{C}$, which is the required temperature before being fed to the diaphragm cell. 
- Electrolysis (Diaphragm Cell): Brine flows through the anode chamber into the diaphragm cell to the cathode. As the brine flows in the anode compartment of the cell, chloride ions are reduced form chlorine gas. The solution then passes through the diaphragm into the cathode chamber, where sodium hydroxide (also known as caustic soda) and hydrogen are produced. The cathode allows liquid to pass through, while avoiding fine chlorine gas bubbles to enter.

- Caustic Soda Evaporation, Concentration, and Flaking: The diluted sodium hydroxide solution, which was passed through the diaphragm cell, contains residual salt that undergoes an evaporation process to produce sodium hydroxide in a usable concentration. The cell liquor is concentrated from the cell through water evaporation from the caustic, thus separating the residual salt from the sodium hydroxide. This results in $50 \%$ sodium hydroxide solution. Further processing can output $70-74 \%$ sodium hydroxide or anhydrous sodium hydroxide, as shown in Figure I-2.

- Chlorine Compression and Liquefaction: The diaphragm provides the muchrequired barrier between the cathode and anode to prevent reaction between $\mathrm{NaOH}$ and $\mathrm{H}_{2}$ with chlorine, and to avoid formation of oxygenated compounds of chlorine. Chlorine gas is collected at the top of the cell, cooled, compressed, and liquefied. Chlorine is cooled using Freon ${ }^{\mathrm{TM}}$ or a similar refrigerant, then washed with sulfuric acid in a packed column to dry it. Spent sulfuric acid is recovered and reused. After drying, chlorine is compressed to a higher pressure to allow liquefaction of the gas and then further collected.

By the nature of the chemical reaction, chlorine, sodium hydroxide, and hydrogen are manufactured in a fixed ratio (i.e., 1.1 tonne of sodium hydroxide and 0.03 tonne of hydrogen per tonne of chlorine). Chlorine is one of the most widely used chemicals, present as feedstock or as an intermediate in a large number of manufacturing processes of many chemicals, plastics (PVC), and medicine. 


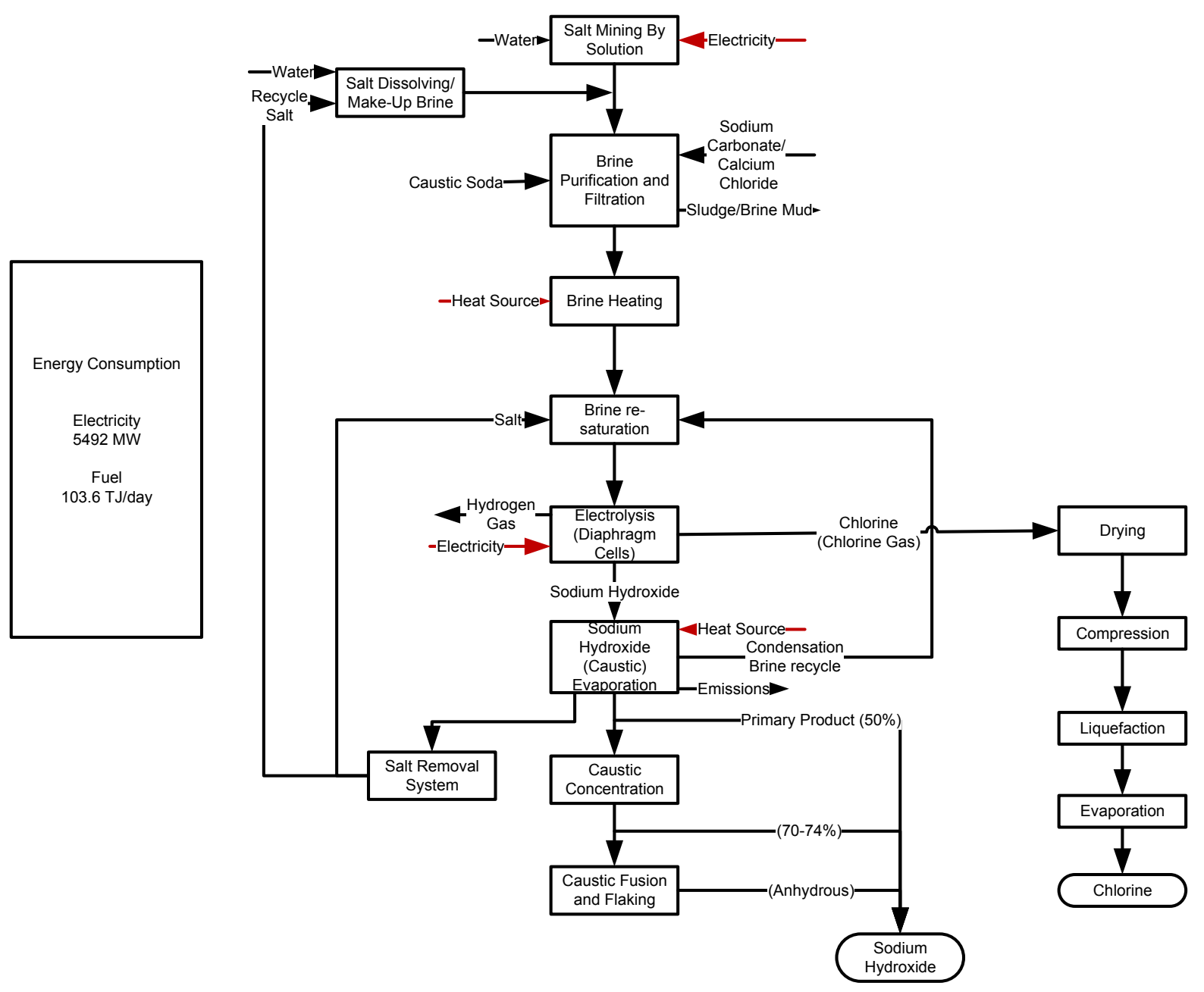

Figure K-2. Sodium hydroxide and chlorine production process flow diagram using electrolysis (diaphragm cell)

(DOE 2000, Kirk-Othmer 2016). 
Table K-1. Chlorine and Alkali Process Summary for the United States.

\begin{tabular}{|c|c|c|}
\hline \multicolumn{3}{|c|}{ Chlor-Alkali Industry Process Results (based on 1997 U.S. Census Bureau) } \\
\hline Facilities & & 39 \\
\hline \multicolumn{3}{|l|}{ Inputs } \\
\hline & Salt $(\mathrm{NaCl})$ (tonnes/day) & 56,544 \\
\hline \multicolumn{3}{|l|}{ Outputs (Production) } \\
\hline & Chlorine (tonnes/day) & 32,311 \\
\hline & Alkali & \\
\hline & Sodium Hydroxide (tonnes/day) & 28,210 \\
\hline \multicolumn{3}{|l|}{ Utility Summary } \\
\hline \multicolumn{3}{|l|}{ Electricity (MW) } \\
\hline & Rectifier & 98.3 \\
\hline & Cell Use & $4,743.8$ \\
\hline & $\mathrm{NaOH}$ Cooling & 92.0 \\
\hline & Hydrogen Cooling/Drying & 202.9 \\
\hline & Chlorine Cooling/Drying & 136.4 \\
\hline & Chlroine Compression & 218.8 \\
\hline Total Electricity (MW) & & 5,492 \\
\hline Avg. Electricity (MW) & & 141 \\
\hline \multicolumn{3}{|l|}{ Heat Source (TJ/day) } \\
\hline & Brine Preparation & 0.55 \\
\hline & $\mathrm{NaOH}$ Concentration & 103.01 \\
\hline Total Heat Source (TJ/day) & & 103.6 \\
\hline Avg. Heat Source (TJ/day) & & 2.7 \\
\hline \multicolumn{3}{|l|}{ Fuel Distribution (TJ/day) } \\
\hline & Oil $(3 \%)$ & 3.1 \\
\hline & Natural Gas (77\%) & 79.7 \\
\hline & Coal and Coke (10\%) & 10.4 \\
\hline & Other $(10 \%)$ & 10.4 \\
\hline & Total & 103.6 \\
\hline \multicolumn{3}{|l|}{ Steam Quality } \\
\hline & Steam Pressure (MPa) & $\begin{array}{c}\text { Steam } \\
\text { Temperature }\left({ }^{\circ} \mathrm{C}\right)\end{array}$ \\
\hline Brine Heating & 0.82 & 177 \\
\hline Evaporator & 0.82 & 177 \\
\hline Water (Mtonnes/day) & & 538 \\
\hline \multicolumn{3}{|l|}{ Emissions } \\
\hline & $\mathrm{CO}_{2}$ Emissions (tonnes/day) & 78,527 \\
\hline
\end{tabular}




\section{Appendix L Nitrogenous Fertilizer Manufacturing (Ammonia Production)}

In 2015, 9.4 million tonnes of ammonia were produced within the United STates and an additional 4.5 million tonnes were imported. Fertilizer production accounted for $88 \%$ of U.S. ammonia use including urea, ammonium nitrates, ammonium phosphates, nitric acid, and ammonium sulfate. Non-fertilizer uses of ammonia are plastic production, explosives, synthetic fibers and resins, and other chemical compounds. A total of 29 U.S. plants in 15 States produced the ammonia. During this time, the plants operated at $80 \%$ of their rated capacity (Apodaca 2016). Plant capacity size within the United States range from 10,000 tonnes/year to 1.7 million tonnes/year.

Ammonia is produced using the Haber-Bosch process in which hydrogen is reacted with nitrogen. Air is the primary source for the nitrogen and steam-reforming of natural gas is the most common source of the hydrogen (Eggeman 2010). The feeds and the products from a process flow model of a conventional natural gas to ammonia plant with ammonia derivative products are shown in Figure L-1. Assuming 80\% plant capacity, the plant produces 891,000 tonnes/year of ammonia, (Wood 2010). Heat is produced in a furnace for the primary steam reformer using $23 \%$ of the natural gas, the remainder is used for feedstock within the reformer to produce the hydrogen needed for the ammonia production and the carbon dioxide for urea production. The heat duty is based on the higher heating value of the natural gas combusted.

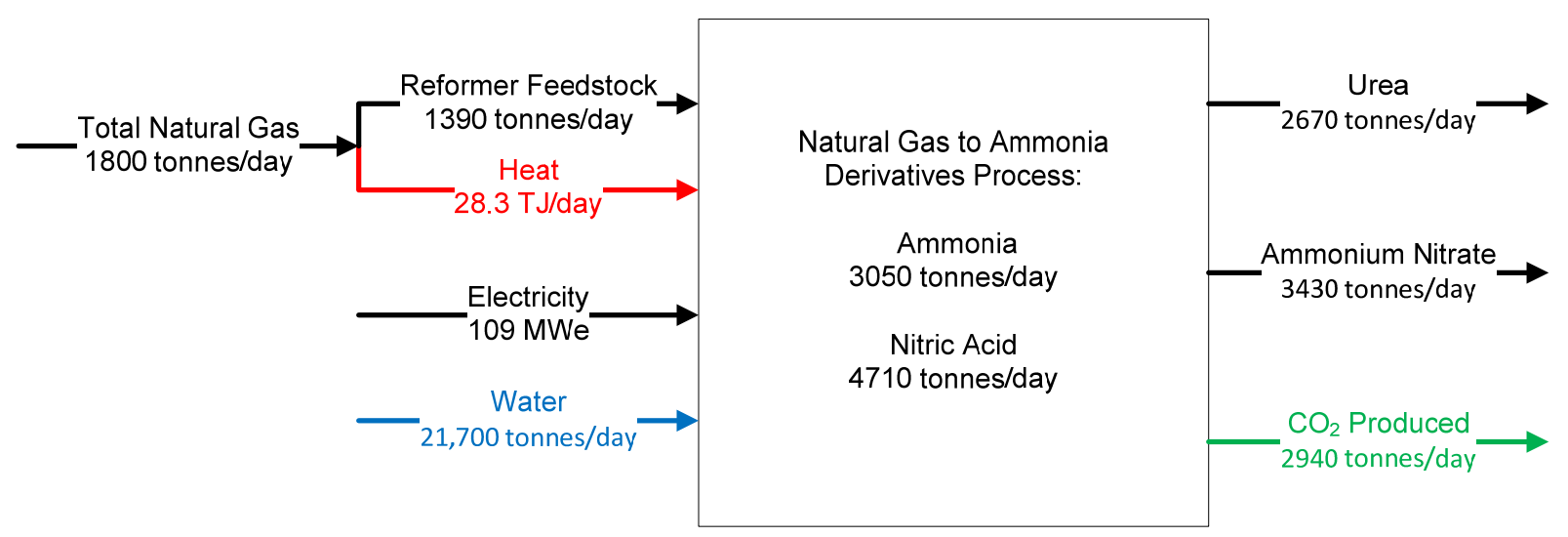

Figure L-1. Summary of material and energy flows for a nominal ammonia plant producing urea and ammonium nitrate

\section{L.1 Description}

A schematic of the ammonia process is shown in Figure L-2.

Natural Gas Purification and Reforming: Synthetic gas (or syngas) for the ammonia process is produced using a two-step reforming process consisting of primary steam reforming followed by secondary auto-thermal reforming. Air is used to burn the natural gas within the auto-thermal reforming process which leaves nitrogen as a by-product for ammonia production. By controlling the process parameters such as steam to carbon molar ratios, primary reformer temperature, and the amount of preheat to the secondary reformer as well as its temperature, the desired 
stoichiometry ratio of $\mathrm{H}_{2} / \mathrm{N}_{2}$ can be achieved for ammonia production. The primary reformer temperature is on the order of $800^{\circ} \mathrm{C}$, whereas the auto-thermal reformer has an outlet temperature near $950^{\circ} \mathrm{C}$. Combusted natural gas exhaust at $850^{\circ} \mathrm{C}$ is used to heat air to $550^{\circ} \mathrm{C}$ that is used in the auto-thermal reforming process. The natural gas exhaust at $725^{\circ} \mathrm{C}$ is used to heat water and natural gas to $550^{\circ} \mathrm{C}$ for the primary reformer. About $23 \%$ of the natural gas is burned to create heat, the remainder is a carbon source for the primary reformer. The syngas exiting the reforming process is $36 \%$ hydrogen, $8 \% \mathrm{CO}, 5 \% \mathrm{CO}_{2}, 15 \% \mathrm{~N}_{2}$, and $35 \%$ water by molar content.

- Syngas Conditioning: The syngas is passed through a sour shift reactor to maximize hydrogen production through the water shift reaction. Excess water is condensed and sent to water treatment. An absorber with a solvent is used to remove the $\mathrm{CO}_{2}$ and trace amounts of sulfur compounds.

- Ammonia Production: The conditioned syngas has a molar composition of $75 \%$ hydrogen and $25 \%$ nitrogen. Incoming feed gas is compressed to $13.8 \mathrm{MPa}$. Preheating of the gas is accomplished by mixing fresh syngas with hot recycle gas exiting the second ammonia synthesis reactor. Equilibrium conversion is assumed in the ammonia converters for the following reaction:

$$
\mathrm{N}_{2}+3 \mathrm{H}_{2} \rightarrow 2 \mathrm{NH}_{3}
$$

Effluent from the first ammonia converter is cooled by cross exchange with the reactor influent, followed by cooling in a steam generator. Additional steam is generated from the hot syngas downstream of the second and third ammonia conversion stages. Final cooling of the third stage effluent gas is accomplished using cooling water and recuperation with the cool recycle gas stream. Ammonia product is recovered in an ammonia separator. Effluent gas from this separator is further cooled using refrigeration. Additional ammonia is recovered in a second separator downstream of the refrigeration unit. Effluent gas from the second separator is recycled to the ammonia converters. Before entering the ammonia converters, the recycle gas is recompressed using a boost compressor and mixed with fresh syngas. Due to the very low concentrations of methane and argon entering the synthesis loop, inert gases pass out of the system absorbed with the ammonia product. Recovered ammonia is flashed to atmospheric pressure for storage. Ammonia in the flash gas is recovered in a wash column and subsequently distilled to remove water from the recovered product.

- Nitric Acid Synthesis: Ammonia is mixed with compressed air and reacted within an ammonia converter to produce nitrogen, NO, and water. The reaction is exothermic, producing temperatures approaching $925^{\circ} \mathrm{C}$. Heat is removed through recuperation and steam generation and the cooled gas reacts with oxygen to produce $\mathrm{NO}_{2}, \mathrm{~N}_{2} \mathrm{O}_{2}$, and $\mathrm{HNO}_{3}$. The aqueous nitric acid is separated from the product stream and the remaining gases are sent to an absorber to increase the production of the acid. Unreacted gas is sent to a selective catalyst reduction unit to remove $\mathrm{NO}_{\mathrm{x}}$ before atmospheric release.

- Ammonium Nitrate Synthesis: Ammonia and nitric acid are preheated and reacted in a neutralizer to form ammonium nitrate. Excess water is removed and $95 \%$ of the remaining solution is recycled back to the neutralizer. The remaining solution is concentrated in a twostage evaporator. The concentrated solution is solidified using a prill tower. 
- Urea Synthesis: Ammonia and $\mathrm{CO}_{2}$ are reacted at 2000 psi to form ammonium carbamate which dehydrates to form urea. The liquid product is fed to a $\mathrm{CO}_{2}$ stripper and downstream decomposer where unreacted ammonium carbamate is decomposed to ammonia and $\mathrm{CO}_{2}$ to allow easy separation of the urea. The recovered ammonia and $\mathrm{CO}_{2}$ are cooled and condensed to reform ammonium carbamate, which is mixed with fresh feed gases and sent back to the reactor. The urea is concentrated through evaporation and then solidified using a fluidized bed granulator.

- Power Generation: Some power is produced from within the plant from high pressure (2.87 $\mathrm{MPa})$ and low pressure $(0.515 \mathrm{MPa})$ steam generated throughout the plant. The power generation is not sufficient to meet the power needs of the process; therefore, power is purchased from the grid.

Table L-1 and Table L-2 list relevant information about the ammonia and ammonia based feedstocks, products, emissions and heat and power usage. To explain the external heat usage, a schematic of the reforming process is shown in Figure L-3. The exhaust gas from the burner supplies heat to each of the locations listed in Table L-2 and is represented by the grey shape in Figure L-3. The exhaust gas provides heat first to the primary reformer and then exchanges heat to preheat the water and natural gas feed streams as well as producing some process steam. Except for the primary reformer, the outlet temperature of the heat exchanger is the inlet temperature of the heat exchanger below as listed in Table L-2. 


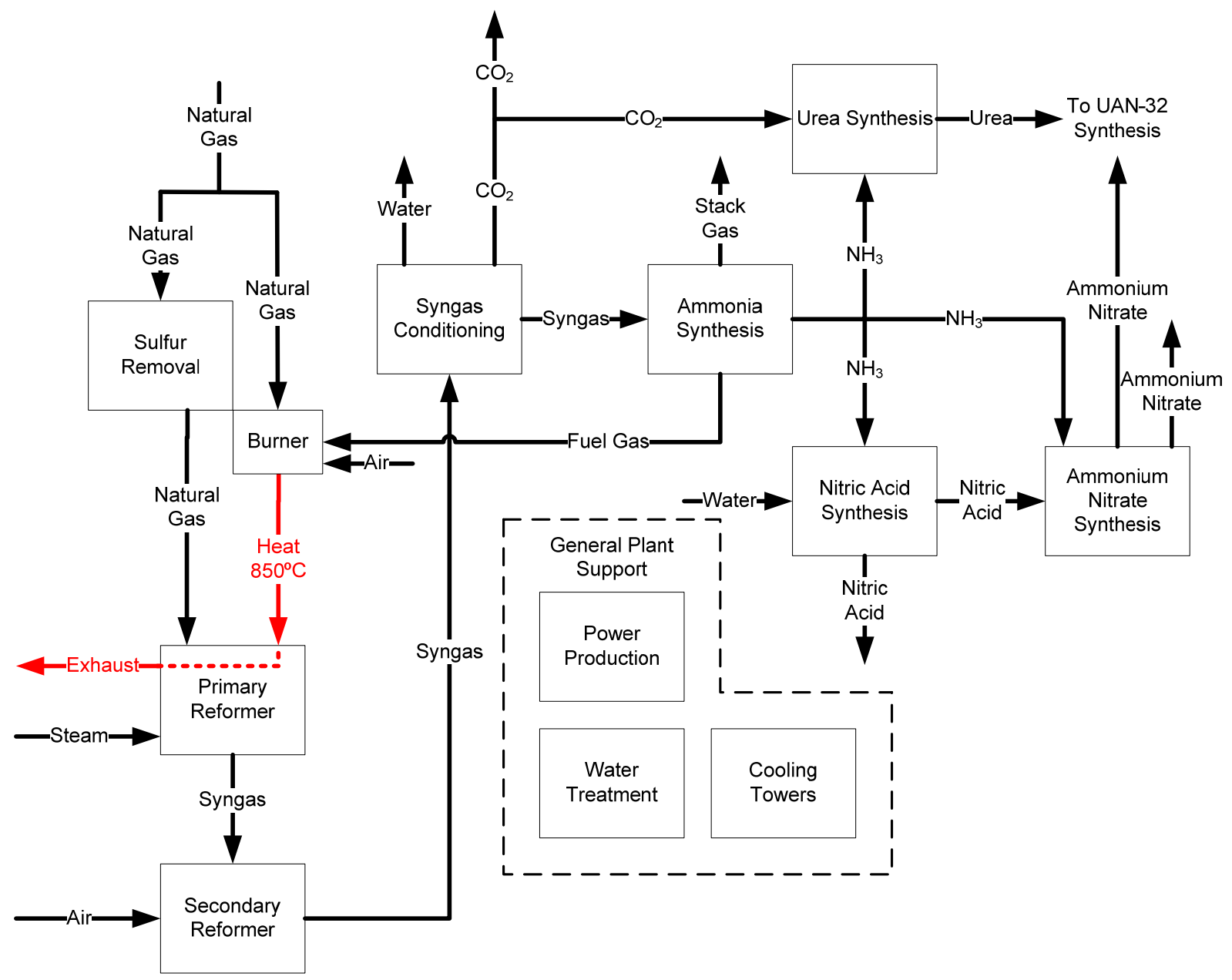

Figure L-2. Schematic of process for making ammonia and its derivatives 
Table L-1. Inputs, Products, Utility, and Emissions of Natural Gas to Ammonia Derivatives Processes

Natural Gas to Ammonia Derivatives Process

\begin{tabular}{|c|c|}
\hline \multicolumn{2}{|l|}{ Inputs } \\
\hline Natural Gas Feed Rate (tonnes/day) & 1804 \\
\hline \multicolumn{2}{|l|}{ Intermediate Outputs } \\
\hline Ammonia (tonnes/day) & 3050 \\
\hline Nitric Acid (tonnes/day) & 4710 \\
\hline \multicolumn{2}{|l|}{ Output } \\
\hline Urea (tonnes/day) & 2670 \\
\hline Ammonium Nitrate (tonnes/day) & 3430 \\
\hline \multicolumn{2}{|l|}{ Utility Summary } \\
\hline Power Produced From Steam & 28.9 \\
\hline \multicolumn{2}{|l|}{ Electrical Consumers } \\
\hline Natural Gas Reforming & -21.6 \\
\hline Syngas Purification & -4.4 \\
\hline Power Block & -2.2 \\
\hline $\mathrm{CO}_{2}$ & -13.0 \\
\hline Ammonia Synthesis & -45.2 \\
\hline Nitric Acid Synthesis & -15.1 \\
\hline Ammonium Nitrate Synthesis & -24.9 \\
\hline Urea Synthesis & -4.4 \\
\hline Cooling Towers & -1.5 \\
\hline Water Treatment & -5.4 \\
\hline Sum of Power Consumption & -137.7 \\
\hline Net Plant Power & -108.8 \\
\hline Total Water Balance (tonnes/day) & $-21,700$ \\
\hline Evaporation Rate (tonnes/day) & $-20,200$ \\
\hline \multicolumn{2}{|l|}{$\mathrm{CO}_{2}$ Emissions } \\
\hline Captured (tonnes/day $\mathrm{CO}_{2}$ ) & 1772 \\
\hline Emitted (tonnes/day $\mathrm{CO}_{2}$ ) & 1164 \\
\hline
\end{tabular}




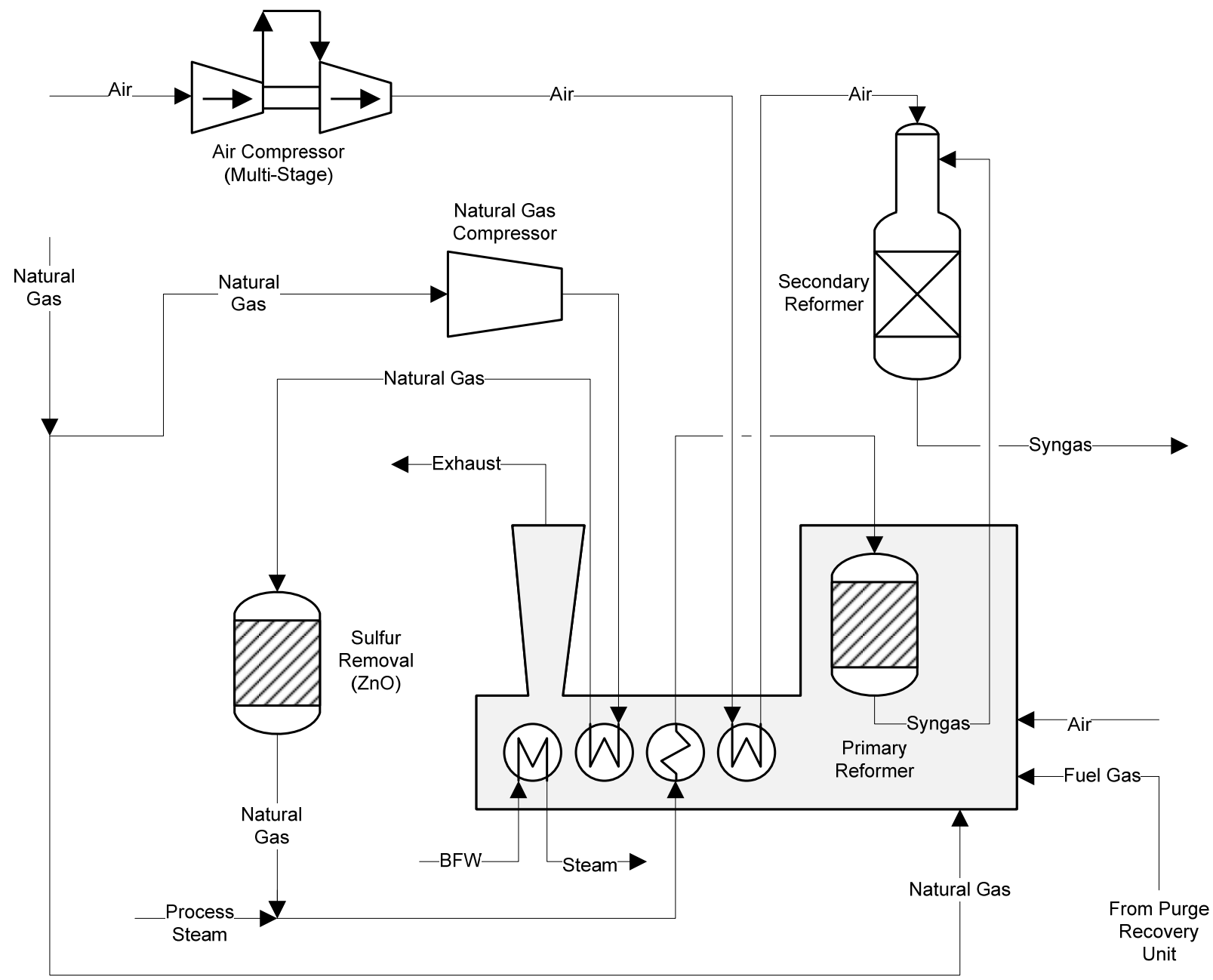

Figure L-3. Schematic of the reforming process, (BFW is boiler feed water)

Table L-2. Heat Addition from Natural Gas

\begin{tabular}{llll}
\hline Location & $\begin{array}{l}\text { Heat Duty } \\
(\mathrm{TJ} / \text { day })\end{array}$ & $\begin{array}{l}\text { Inlet } \\
\text { Temperature }\left({ }^{\circ} \mathrm{C}\right)\end{array}$ & $\begin{array}{l}\text { Outlet } \\
\text { Temperature }\left({ }^{\circ} \mathrm{C}\right)\end{array}$ \\
\hline $\begin{array}{l}\text { Primary reformer } \\
\begin{array}{l}\text { Preheat steam/air into secondary } \\
\text { reformer }\end{array}\end{array}$ & 14.484 & 538 & 790 \\
$\begin{array}{l}\text { Preheat steam/NG into primary } \\
\text { reformer }\end{array}$ & 1.405 & 842 & 728 \\
Preheat steam before mix with NG & 2.568 & 728 & 512 \\
Preheat NG before mix with steam & 1.699 & 512 & 362 \\
NG preheat & 1.013 & 362 & 271 \\
Steam preheat & 0.309 & 271 & 242 \\
Process preheat & 0.056 & 242 & 237 \\
Process preheat & 0.446 & 237 & 195 \\
& 0.608 & 195 & 138
\end{tabular}




\section{L.2 References}

Apodaca, Lori E. 2016. U.S. Geological Survey, Mineral Commodity Summaries: Nitrogen (Fixed)-Ammonia. January. Accessed July 11, 2016.

http://minerals.usgs.gov/minerals/pubs/commodity/nitrogen/mcs-2016-nitro.pdf.

Eggeman, Tim. 2010. "Ammonia." In Kirk-Othmer Encyclopedia of Chemical Technology, 133. John Wiley \& Sons, Inc.

Wood, Rick A. 2010. Nuclear-Integrated Ammonia Production Analysis, TEV-666 Rev. 2. Idaho Falls: Idaho National Laboratory. 


\section{Appendix M Wet Corn Milling}

Wet corn milling (WCM) is also known as corn refining. Corn is a primary source of starch used in food, paper, and ethanol industries. The objective of WCM is to separate the corn kernel into its main components (starch, germ, fiber, steep liquor, and protein [gluten]) and to recover the maximum amount of starch as possible from the process. WCM plants in the United States process 100,000 bushels per day or 2,540 tonnes/day and operate continuously for nearly 365 days per year (Galtsky et al. 2003). Major WCM outputs are corn sweeteners (corn or glucose syrup, dextrose, and high fructose corn syrup) and ethanol from further processing of starch. Figure M-1 shows the yield of corn components from the process (Blanchard 1992, Matz 1991). The heat required in the WCM process of $8 \mathrm{TJ} /$ day is met by natural gas.

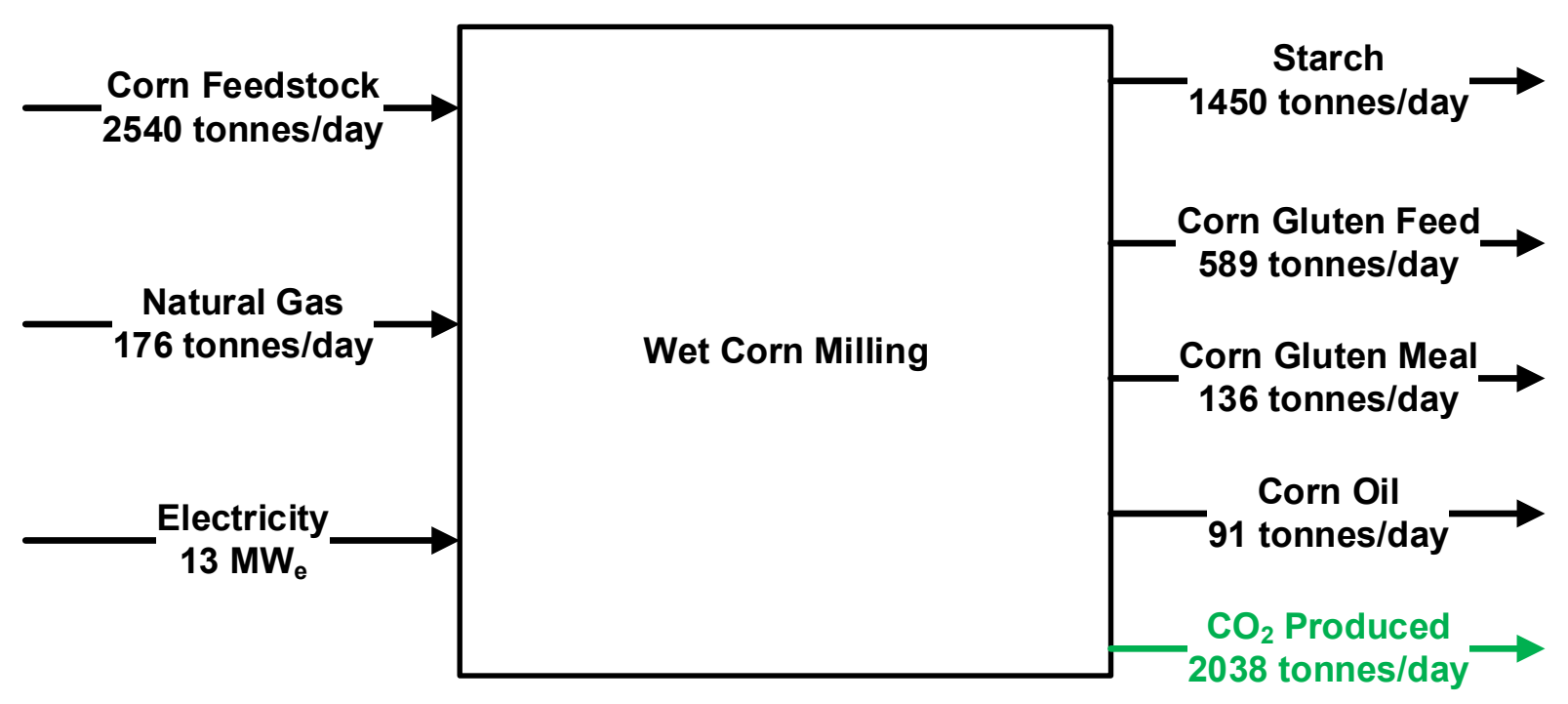

Figure M-1. Material and energy flows for a nominal WCM plant

(Based on 100,000 bushels per day; 1 bushel $=56$ pounds or $25.4 \mathrm{~kg}$ ).

\section{M.1 Process Description}

As the name suggests, WCM is a wet process; it uses water as a medium for separating the main components, but the output produced is a dry product. The corn kernels are cleaned of all debris and foreign material to prevent (1) clogging of screens, (2) quality effects to the finished product, and (3) increasing viscosity for the main process stream. The WCM process flow diagram is shown in Figure M-2.

Steeping Stage: In the steeping stage, corn kernels are soaked in a solution containing sulfur dioxide $\left(\mathrm{SO}_{2}\right)$ and mildly acidic water (lactic acid; $\left.\mathrm{C}_{3} \mathrm{H}_{6} \mathrm{O}_{3}\right)$ with approximately a $\mathrm{pH}$ of 4 at about $50^{\circ} \mathrm{C}$ for $20-36$ hours. Steeping occurs in series of tanks referred as steeps, which are operated in continuous batch process. The presence of $\mathrm{SO}_{2}$ avoids the growth of micro-organisms and reacts with proteins to release starch granules. The presence of acidic water contributes to softening the kernel and increasing the $\mathrm{SO}_{2}$ diffusion speed. Overall efficiency of the WCM process is dependent on the proper steeping of the corn. The water from the corn soak, is referred to as steepwater. Steepwater contains soluble material from the corn along with a significant percentage of proteins and sugars. The moisture content in the corn kernel increases from 15- 
$45 \%$ during steeping. The corn does not move but the steepwater is transferred through different tanks from the oldest steeped corn to the freshest.

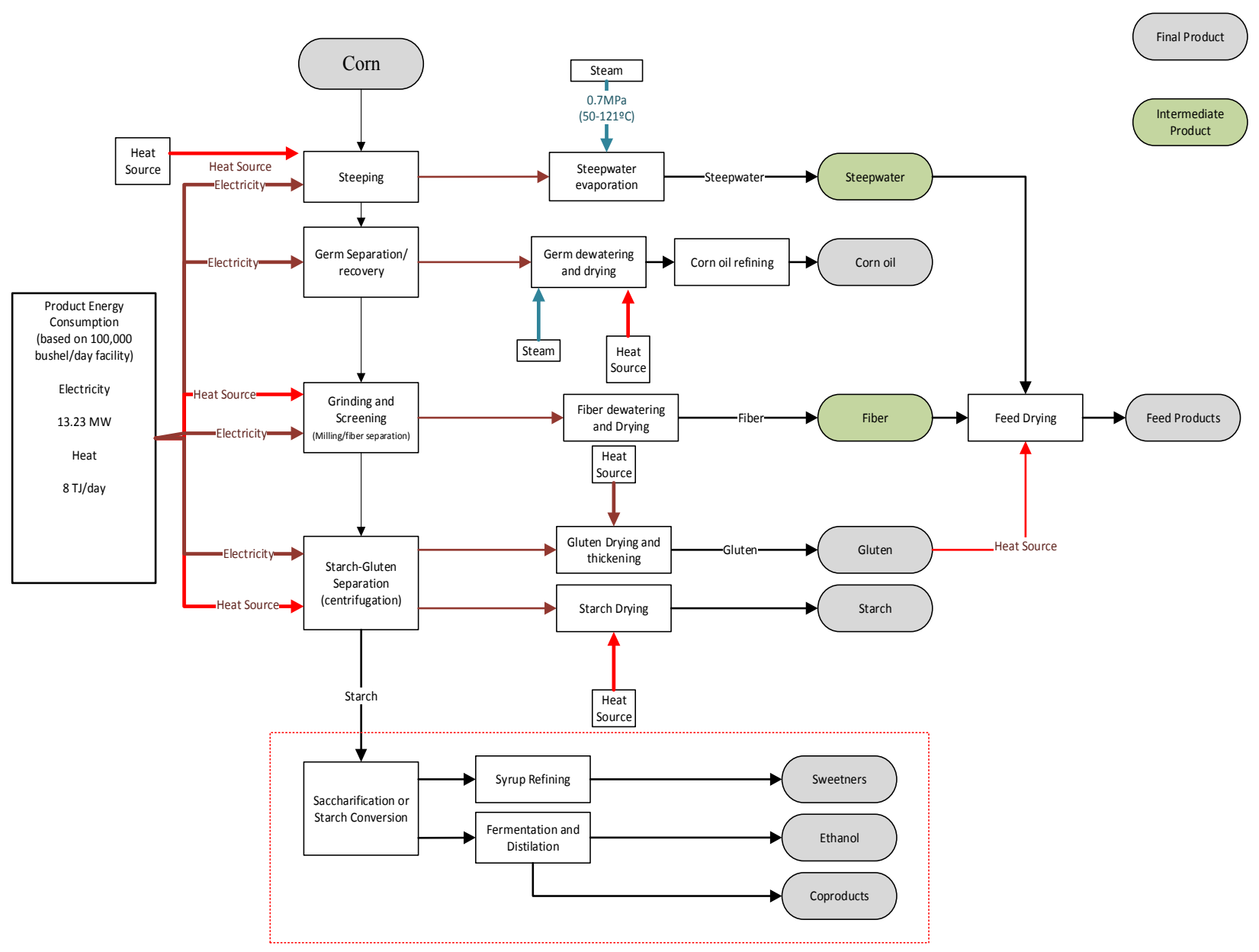

Figure M-2. WCM process diagram

Degermination: The slurry generated by the coarse grinding that follows steeping undergoes a degermination (separation) process to separate the germ from the other components. Corn germ contains most of the oil, which is less dense than water and separated using hydrocyclone separators. The germ is pumped into a series of screens to remove the loose gluten and starch, then washed repeatedly to recover and return all starch to the main stream. To achieve a moisture content of $2-4 \%$, the germ is dried using a rotary steam tube dryer. The germ could also be dried using a fluidized bed dryer. After the germ is dried, corn oil is extracted through a combination of chemical and mechanical processes.

Grinding and Screening: The slurry from hydrocylones undergoes fine grinding and screening to liberate all the starch and gluten from the fiber. This is followed by fiber water wash to recover as much starch and gluten from the main stream as possible. Fiber is then dewatered in two steps: (1) using a screen centrifuge (using a perforated plate screen) followed by (2) a screw press to reduce the moisture content to $10 \%$. Corn steep liquor is added to the moist fiber and the mixture is dried using a rotary dryer with a co-current hot air stream. 
Starch-Gluten Separation: The solution remaining after fiber is extracted is a mixture of starch-gluten that undergoes separation using centrifuges because of the density difference between gluten and starch. Gluten is dewatered by using a filter from a belt vacuum filter or rotary drum filter. Starch that will be sold directly, instead of being converted into ethanol or syrups, needs to be completely dried to a powder. A series of hydrocyclones or the filtering system is the final step used to separate the starch from gluten. Starch slurry then goes through a washing stage and is dried to attain a moisture content of $33-42 \%$ with the help of a spray or film dryer or fluid bed dryers, depending on the batch size.

Saccharification (Starch Conversion): Starch can be modified to produce a broad range of products for various applications. Starch that is not dried goes through the saccharification process to obtain sugar syrups. In this process, starch slurries cannot be held for too long, otherwise microorganisms begin to develop, affecting color, odor, and physical properties of starch.

\section{M.2 Energy Usage}

WCM is a very energy intensive industry. Figure M-3 provides the process steps and their respective percentage of energy usage. Figure M-3 also shows that processes for dewatering, drying, and evaporating are major sources of energy consumption in the process.

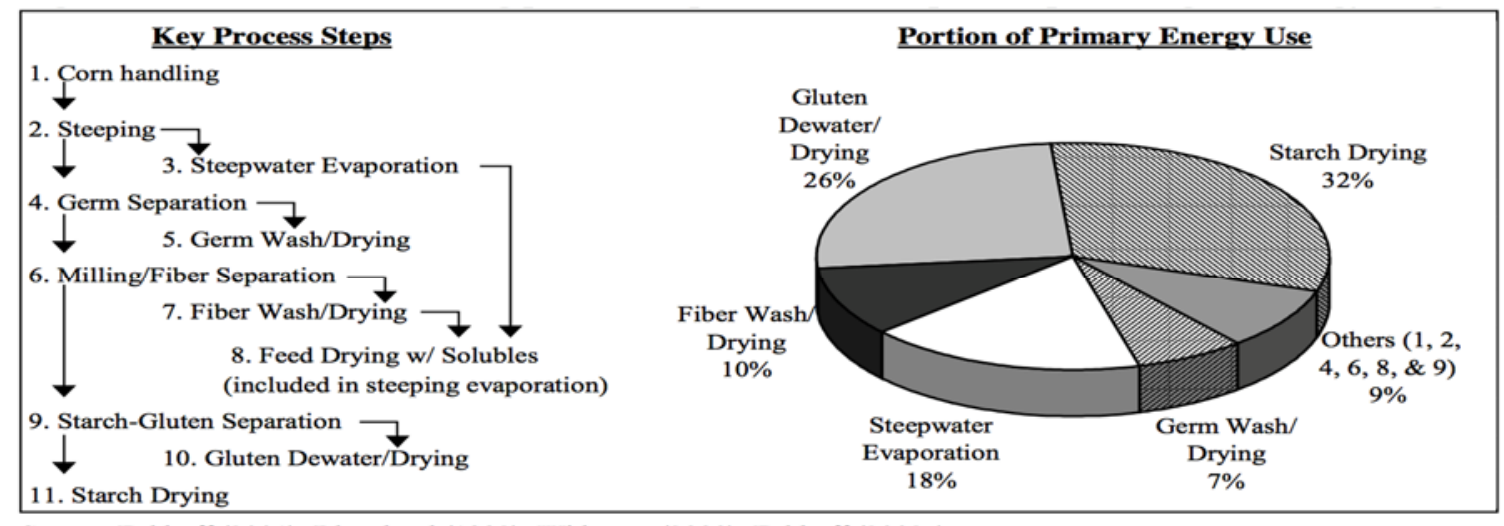

Source: Eckhoff (2001); Blanchard (1992); Wideman (2000); Eckhoff (2002c)

Figure M-3. WCM process steps along with energy usage

WCM requires electricity and the possible use of steam for steam tube dryers; thus, a combined heat and power plant for cogeneration may be applicable. Table M-1 summarizes the energy usage for WCM. Currently, most of the WCM plants generate both electricity and thermal energy heat by burning coal or natural gas to generate steam. Table M-2 provides the estimated energy consumption for processes in WCM operations. 
Table M-1. Energy usage in WCM process

\begin{tabular}{|l|l|}
\hline Utilities & Usage \\
\hline Electricity & $\begin{array}{l}\text { Mostly used for pumping, grinding, separating, and drying the } \\
\text { corn product. }\end{array}$ \\
\hline Fuel (NG or Coal) & Used to make steam and direct drying purposes. \\
\hline Steam & $\begin{array}{l}\text { Used for evaporation, drying, maintaining process } \\
\text { temperature, fermentation, extraction, ethanol recovery, and } \\
\text { conversion of starch in refineries. }\end{array}$ \\
\hline
\end{tabular}

Table M-2. Energy usage in WCM process

\begin{tabular}{|c|c|c|}
\hline \multicolumn{3}{|c|}{ Corn Wet Milling (based on 2010 EIA MECS) } \\
\hline Facilities & & 67 \\
\hline \multicolumn{3}{|l|}{ Average Annual Energy Use } \\
\hline Natural Gas (TJ/day) & 2.271 & \\
\hline Coal (TJ/day) & 4.816 & \\
\hline Heat (TJ/day) & 8 & \\
\hline Electricity (MW) & 13 & \\
\hline \multicolumn{3}{|c|}{ Corn Wet Milling (based on 100,000 bushel/day Facility) } \\
\hline Corn Feedstock (tonnes/day) & 2540 & \\
\hline Process & Electricity Consumed (MW $\mathrm{MW}_{\mathrm{e}}$ day) & Heat Required (TJ/day) \\
\hline Corn Receiving & 0.0014 & \\
\hline Steeping & 0.0007 & 0.0025 \\
\hline Steepwater Evaporation & 0.0018 & 2.058 \\
\hline Germ Recovery(Grinding and Washing) & 0.0035 & \\
\hline Germ Dewatering and Drying & 0.0015 & 0.715 \\
\hline Fiber Recovery & 0.0072 & \\
\hline Fiber Dewatering & 0.0013 & \\
\hline Protein (Gluten) Recovery & 0.0033 & \\
\hline Gluten Thickening and Drying & 0.0017 & 0.375 \\
\hline Starch Washing & 0.0016 & \\
\hline Starch Dewatering and Drying & 0.0089 & 2.848 \\
\hline Gluten Feed Dryer & 0.0033 & 2.365 \\
\hline Total Power $\left(\mathrm{MW}_{\mathrm{e}}\right)$ & 13.23 & \\
\hline Total Heat Required (TJ/day) & & 8.36 \\
\hline \multicolumn{3}{|l|}{ Emissions } \\
\hline Avg. $\mathrm{CO}_{2}$ Emissions (tonnes/day)* & 2,038 & \\
\hline \multicolumn{3}{|c|}{ Steam Temperature and Quality ( $0.7 \mathrm{MPa})$} \\
\hline \multicolumn{3}{|c|}{ Steam Temperature $\left({ }^{\circ} \mathrm{C}\right)$} \\
\hline Steeping & $50-121$ & \\
\hline Steepwater Evaporation & $50-121$ & \\
\hline Germ Dewatering and Drying & $130-168$ & \\
\hline
\end{tabular}




\section{Appendix $\mathbf{N}$ Lime and Cement Manufacturing}

Limestone (calcium carbonate or $\mathrm{CaCO}_{3}$ ) is an essential raw material for production of lime/quicklime $(\mathrm{CaO})^{\mathrm{z}}$. It is often associated with some amount of magnesium carbonate $\left(\mathrm{MgCO}_{3}\right)$, which is then referred to as dolomite when they occur in approximately equal proportions. Limestone and dolomite are widely used to produce cement block, cinder block, socalled cultured stone, mortar, and other related construction materials. It is blended with shale and clay minerals (and coal flyash) containing $\mathrm{SiO}_{2}, \mathrm{Al}_{2} \mathrm{O}_{3}$, and $\mathrm{Fe}_{2} \mathrm{O}_{3}$, to produce calcium alumno-silicates - known as Portland cement - in very high-temperature gas/solid-fired cement kilns approaching temperatures of up to $1,500^{\circ} \mathrm{C}$ (Othmer 2016). In 2015, U.S. production of lime and cement is $5.4 \%$ and $2 \%$ of the world production, respectively.

\section{Lime Production}

Lime manufacturing kilns are operated at temperatures of $900-1200^{\circ} \mathrm{C}$ to dissociate calcium and magnesium carbonates into their respective oxides and carbon dioxide, according to the following reactions:

$$
\begin{aligned}
& \mathrm{CaCO}_{3}+\text { heat }-->\mathrm{CO}_{2}+\mathrm{CaO}(\text { Calcium Lime) } \\
& \mathrm{CaCO}_{3} \cdot \mathrm{MgCO}_{3}+\text { heat }-->2 \mathrm{CO}_{2}+\mathrm{CaO} \cdot \mathrm{MgO} \text { (Dolomitic Lime) }
\end{aligned}
$$

Commercial lime products fall into three main categories: calcium limes, hydraulic limes, and dolomitic limes. Over $95 \%$ of limestone is produced by open-cast quarrying, with less than 5\% being extracted by underground mining.

Lime grade varies based on chemical and physical properties of limestone, type of lime kiln, fuel used, kiln settings, and control parameters and how the lime is processed. Figure N-1summarizes the material and energy flow for a nominal size lime production plant with required heat input of $10.1 \mathrm{TJ} /$ day which is met by natural gas.

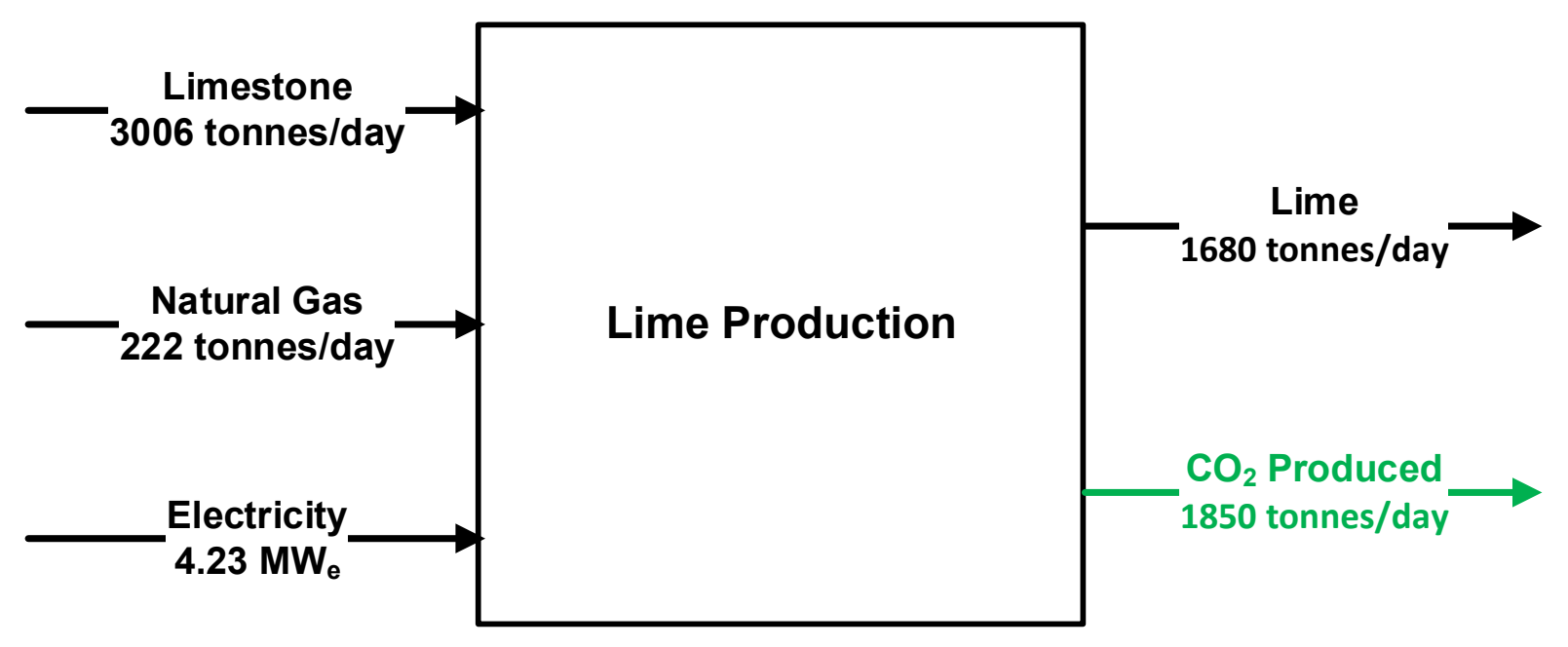

Figure N-1. Material and energy flow summary for a nominal lime production plant

\footnotetext{
${ }^{\mathrm{z}}$ Lime and Quicklime are interchangeably used in the industry.
} 
Proper lime kiln design is important to achieve specific characteristics and quality. Lime kilns can be subdivided into three main groups: countercurrent shaft kilns, shaft kilns with concurrent flow, and rotary kilns. Table N-1 provides net heat and electricity usage for the different types of kilns commonly used. The rotary kiln is the most prevalent type used in the United States, accounting for about $90 \%$ of all lime production.

Table N-1. Energy usages of different types of lime kiln (Othmer 2016)

\begin{tabular}{|l|l|l|}
\hline Kiln Type & Net Heat Usage (KJ/kg) & Electricity Usage (kWh/t) \\
Parallel-Flow Regenerative & $3,600-4,200$ & $18-25$ \\
Annular Shaft & $3,950-4,600$ & $18-35$ \\
Countercurrent Shaft & $4,200-5,000$ & $20-40$ \\
Preheater Rotary & $5,000-6,000$ & $20-45$ \\
Long Rotary & $6,500-7,500$ & $10-15$ \\
\hline
\end{tabular}

Lime kilns are usually fired with a carbon fuel. Electrical power is mostly used for limestone screening, grinding, and hydrating of lime (post calcining). A process flow diagram for the production of lime is shown in Figure N-2.

Feedstock: The feedstock for lime production is calcium carbonate and/or calcium magnesium carbonate mineral that is extracted from quarries to produce lime or dolomitic lime.

Quarry and Crushing: The limestone is quarried and crushed to a particle size, varying between 15 and $40 \mathrm{~mm}$, before being fed into the kiln (Hokfors et al. 2012).

Drying, Heating, and Calcination: The limestone feed enters the kiln at the upper end of the kiln (viz., Figure N-3) and the rotation of the kiln forces the material downwards. As the limestone comes in direct contact with the hot gases the limestone is dried, heated, and then calcined. As shown for the steps in Portland cement manufacturing, limestone itself is converted to calcium oxide at temperatures ranging between $900-1200^{\circ} \mathrm{C}$. The product of calcining is often referred to as quicklime (or just lime), dolomite lime when it contains a high amount of magnesium oxide. The clinker product is crushed or pulverized, depending on its intended use.

Either quicklime or dolomitic lime may be hydrated or combined with water by using a slaker to produce slaked lime and slaked dolomitic lime. This is an exothermic reaction that generates 1.14 MJ per $\mathrm{kg}$ of $\mathrm{CaO}$ (Stork et al. 2016).

The theoretical minimum energy consumption in a lime kiln is $3.18 \mathrm{GJ}$ per tonne of $\mathrm{CaO}$ produced (Stork et al. 2016), assuming complete conversion of limestone into lime. The majority of the energy consumption occurs in the lime production process where the heat is required in the kiln for calcination. The electricity consumption in the lime production process is small (on the order of $60 \mathrm{kWh} /$ tonne of lime product). Table N-2 and Table N-3 provide the average $\mathrm{CO}_{2}$ emissions and net energy requirement for production of lime, respectively. 
Table N-2. Average $\mathrm{CO}_{2}$ intensities for various lime products

\begin{tabular}{|l|c|c|c|c|}
\hline \multicolumn{1}{|c|}{ Lime Product } & $\begin{array}{c}\text { Process } \\
\text { Emissions* }\end{array}$ & $\begin{array}{c}\text { Combustion } \\
\text { Emissions* }\end{array}$ & $\begin{array}{c}\text { Electricity } \\
\text { Emissions* }\end{array}$ & $\begin{array}{c}\text { Total } \\
\text { Emissions* }\end{array}$ \\
\hline Quicklime & 0.751 & 0.322 & 0.019 & 1.092 \\
Dolomitic Lime & 0.807 & 0.475 & 1.301 \\
\hline
\end{tabular}

${ }^{*}$ Emissions in tonnes of $\mathrm{CO}_{2}$ per tonne lime product.

(Stork et al. 2016).

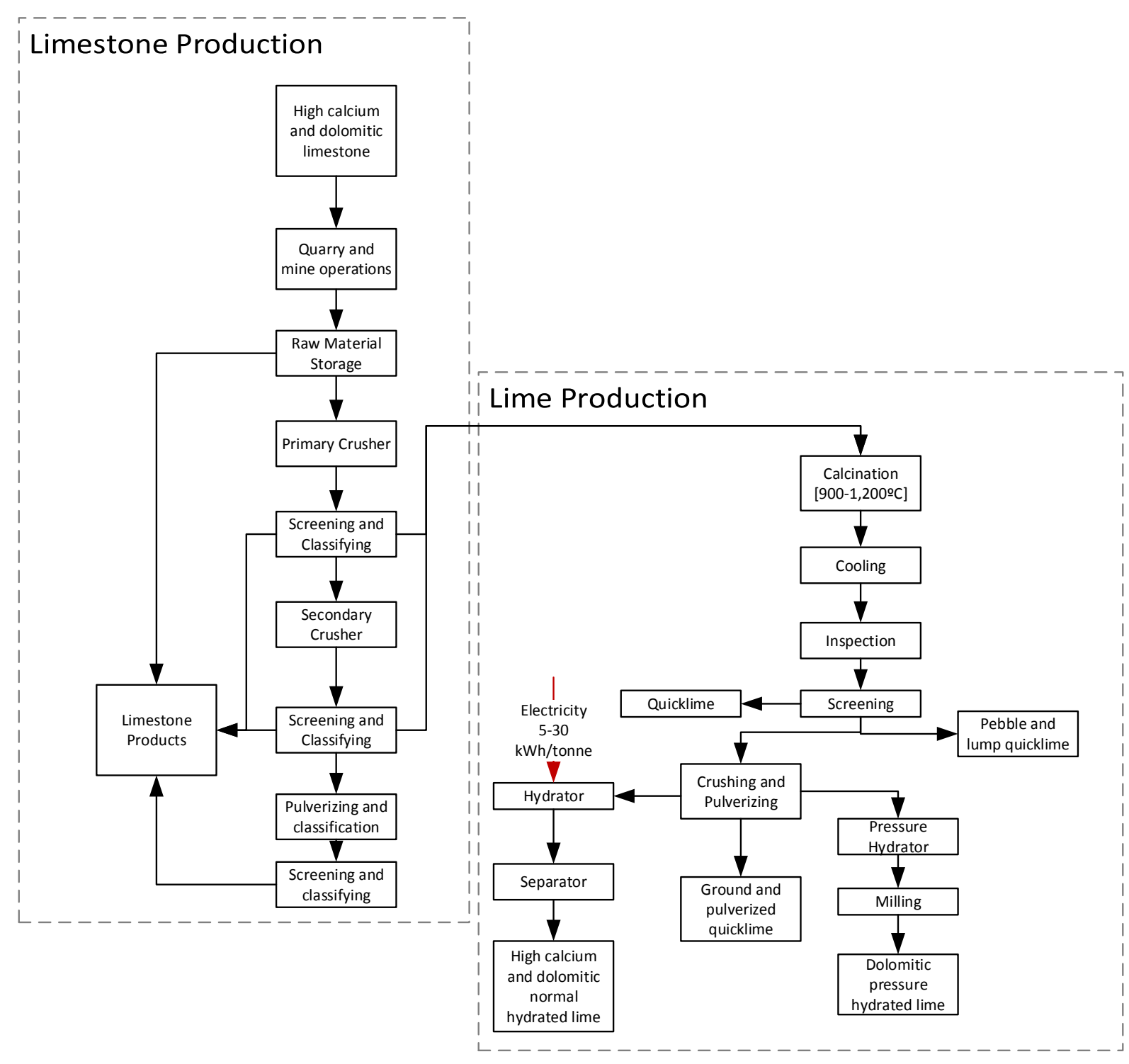

Figure N-2. Lime production process flow diagram

(EPA 1998, DOE 2013, Bleiwas 2011) 
Conversion of calcium carbonate to calcium oxide is achieved by heating the limestone to drive off carbon dioxide. The associated equation, with approximate molecular weight is (Hill and Mason 1997):

$$
100 \mathrm{CaCO}_{3}+\text { heat }-->44 \mathrm{CO}_{2}+56 \mathrm{CaO}
$$

Thus, 1 tonne of limestone produces $560 \mathrm{~kg}$ of lime. Table L-3 provides the net energy requirement and $\mathrm{CO}_{2}$ emissions for production of Lime, respectively.

Table N-3. Lime production energy usage* (Production and Facilities based on 2015)

\begin{tabular}{|c|c|}
\hline $\begin{array}{l}\text { Lime Industry } \\
\text { Facilities in United States }\end{array}$ & 31 \\
\hline \multicolumn{2}{|l|}{$\begin{array}{l}\text { Produced (tonnes/yr) } \\
\text { Lime }\end{array}$} \\
\hline United States & $1.90 \mathrm{E}+07$ \\
\hline World & $3.50 \mathrm{E}+07$ \\
\hline \multicolumn{2}{|l|}{ INPUTS (tonnes/day) } \\
\hline Limestone (United States) & $9.32 \mathrm{E}+04$ \\
\hline \multicolumn{2}{|l|}{ OUTPUTS (tonnes/day) } \\
\hline Lime (United States) & $5.21 \mathrm{E}+04$ \\
\hline \multicolumn{2}{|l|}{ UTILITIES } \\
\hline \multicolumn{2}{|l|}{ Rotary Kiln } \\
\hline \multicolumn{2}{|l|}{ Total Heat Usage (TJ/day) } \\
\hline Fuel (Natural Gas/Coal/Oil) (TJ/day) & $3.12 \mathrm{E}+02$ \\
\hline Avg. Heat Usage (TJ/day) & $1.01 \mathrm{E}+01$ \\
\hline Total Electricity Usage $\left(\mathrm{MW}_{\mathrm{e}}\right)$ & $1.31 \mathrm{E}+02$ \\
\hline Avg. Electricity Usage $\left(\mathrm{MW}_{\mathrm{e}}\right)$ & $4.23 \mathrm{E}+00$ \\
\hline \multicolumn{2}{|l|}{ EMISSIONS (tonnes/day) } \\
\hline $\mathrm{CO}_{2}$ Emissions & $5.73 \mathrm{E}+04$ \\
\hline
\end{tabular}

*Based on U.S. Census production in 2015 (http://minerals.usgs.gov/minerals/pubs/commodity/lime/mcs2016-lime.pdf) 
Cement Production

Cement making consists of three stages:

4. Grinding a mixture of limestone and clay or shale to make a fine "rawmix" (see Rawmill)

5. Heating the rawmix to sintering temperature (up to $1,500^{\circ} \mathrm{C}$ ) in a cement kiln (Figure $\mathrm{N}-3)$

6. Grinding the resulting clinker (Figure N-4) to make cement.

In the second stage, the rawmix is fed into the kiln and gradually heated by contact with the hot gases from combustion of the kiln fuel. Successive chemical reactions take place as the temperature of the rawmix rises:

- 70 to $110^{\circ} \mathrm{C}$ - Free water is evaporated.

- 400 to $600^{\circ} \mathrm{C}$ - Clay-like minerals are decomposed into their constituent oxides; principally $\mathrm{SiO}_{2}$ and $\mathrm{Al}_{2} \mathrm{O}_{3}$.

- 500 to $900^{\circ} \mathrm{C}$ - Limestone and dolomite commence decomposition to form $\mathrm{CaO}, \mathrm{MgO}$, and $\underline{\mathrm{CO}_{2}}$.

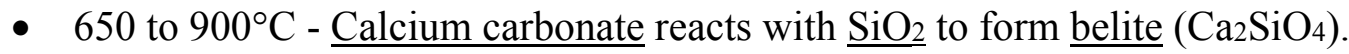

- 900 to $1050^{\circ} \mathrm{C}$ - All remaining limestone and dolomite decompose.

- 1300 to $1450^{\circ} \mathrm{C}$ - Partial (20-30\%) melting takes place, and belite reacts with calcium oxide to form tri-calcium, alumno-silicate (alite or $\left.\mathrm{Ca}_{3} \mathrm{O} \cdot \mathrm{SiO}_{4}\right)$, which is the characteristic constituent of Portland cement. In the presence of $\mathrm{Al}_{2} \mathrm{O}_{3}$, tricalcium aluminate $(\mathrm{CaO})_{3} \mathrm{Al}_{2} \mathrm{O}_{3}$, or in the presence of $\mathrm{Fe}_{2} \mathrm{O}_{3}$, tetracalcium alumino-ferrite $(\mathrm{CaO})_{4} \mathrm{Al}_{2} \mathrm{O}_{3} \mathrm{Fe}_{2} \mathrm{O}_{3}$ is formed. Each of these can help accelerate the rate of hydration or setting of cement. 


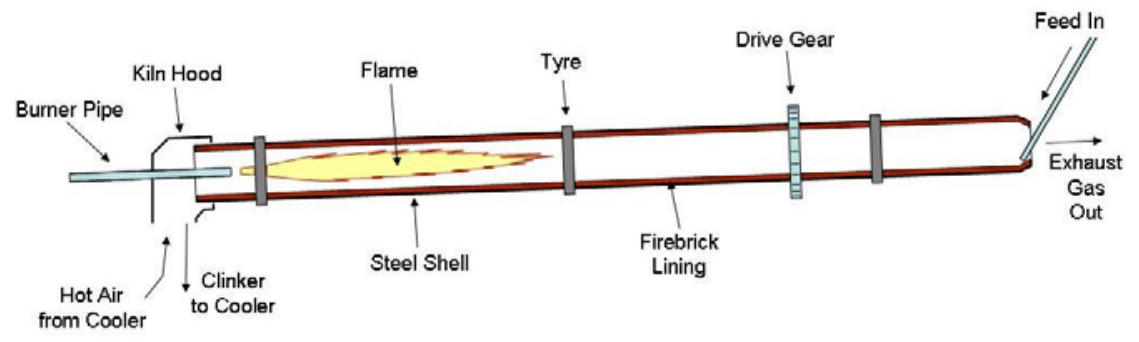

Figure N-3. Typical Gas-Fired Portland cement kiln

(Flame temperatures reach $1,900-2,000^{\circ} \mathrm{C}$ ).

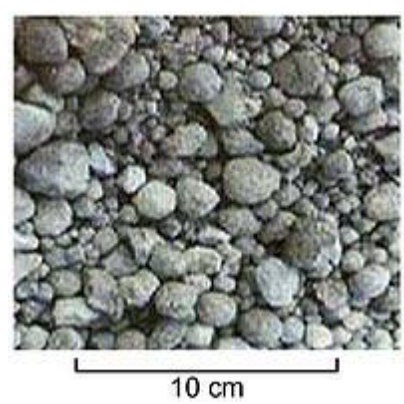

Figure N-4. Typical Portland cement clinker nodules

Cement kilns are primarily firing with coal, petroleum coke, heavy fuel oil, natural gas, landfill off-gas, and oil refinery flare gas. The clinker is brought to its peak temperature mainly by radiant heat transfer, and a bright (i.e., high emissivity) and a hot flame is essential for this.

In addition to these primary fuels, various combustible waste materials have been fed to kilns, notably used tires, which are very difficult to dispose of by other means. In theory, cement kilns are an attractive way of disposing of hazardous materials. Figure L-4 summarizes the material and energy flow for a nominal size cement production plant with the heat requirement of $9.37 \mathrm{TJ} /$ day, being met by natural gas.

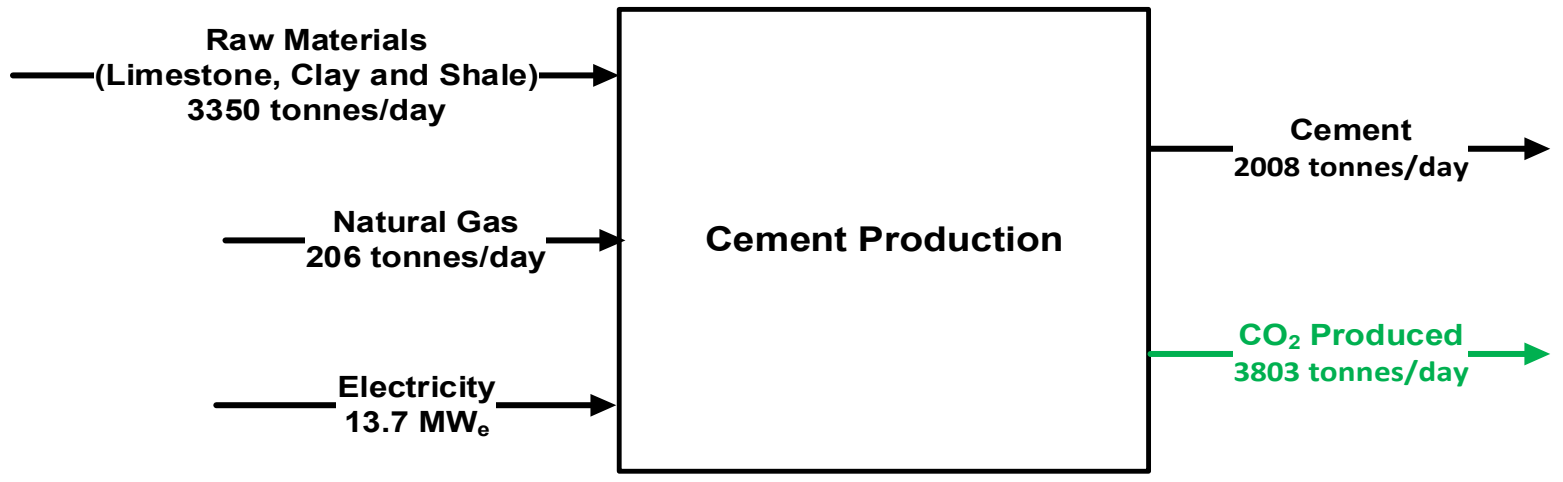

Figure N-5. Material and energy flow summary for a nominal cement production plant 
The production process for cement can be divided into the following steps:

Mining, Quarrying, and Screening: Raw materials used for cement production are limestone, shale, and clay. Limestone provides the required calcium oxide, while shale, clay, and other materials provide most of the silicon, aluminum, and iron oxides required to produce portland cement. Limestone is mostly extracted from open-face quarries. The size reduction takes place by processing the raw material through a series of crushers.

Feed Preparation for Kiln: After size reduction, the raw materials are further reduced in size by grinding. There are two processing methods to produce cement, mainly dry processing and wet processing. In dry processing, the raw materials are ground into a flowable powder in horizontal ball mills or vertical roller mills. The moisture content in the kiln feed of the dry kiln is typically around $0.5 \%$. In the wet process, the raw materials are ground with water to produce slurry (containing $24-48 \%$ water).

Clinker Production (Pyro-Processing): Clinker production is the most energy-intensive stage in cement production. Clinker is produced by pyroprocessing in large kilns. The main type of kiln used in the industry is the rotary kiln. The kiln evaporates the inherent water in the feed, calcines the carbonate constituents (calcination), and helps form cement minerals. The capacity of larger units is up to 3600 tonnes of clinker per day. Dry rotary kiln feed material has much lower moisture content $(0.5 \%)$, thereby reducing the need for evaporation and reduction of kiln length. After the clinker is formed in the rotary kiln, it is cooled rapidly to minimize the formation of a glass phase and to ensure the maximum yield of alite (tricalcium silicate) formation, a required component for the hardening properties of cement.

Grinding Mill Finish: To produce powdered cement, the nodules of cement clinker are ground to the consistency of very fine powder. In the process other additives are added to the process, such as gypsum, to control the setting properties of the cement. 


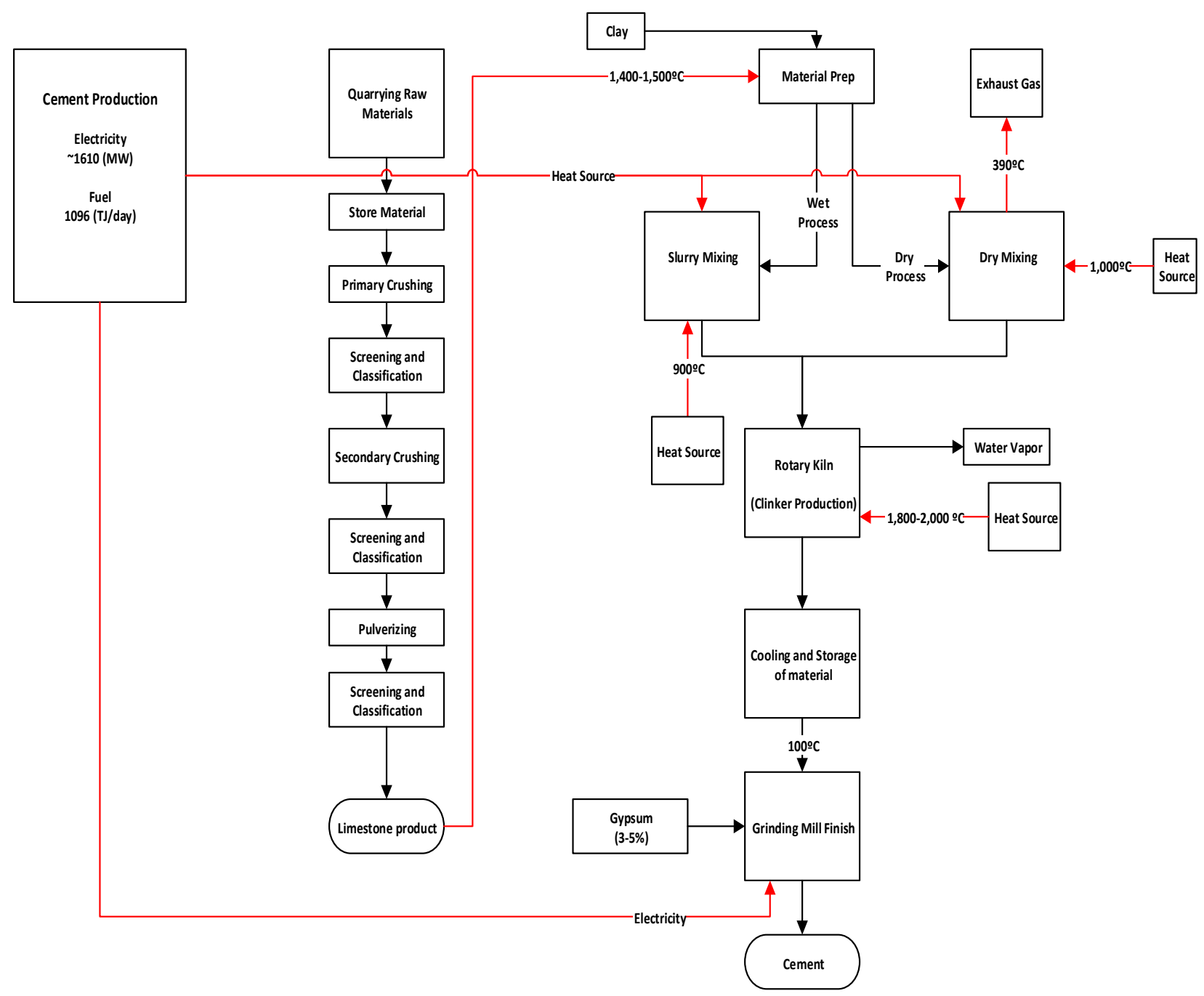

Figure N-6. Cement Production Process

Table N-4 provides the net energy requirement and $\mathrm{CO}_{2}$ emissions for production of cement, respectively. 
Table N-4. Cement production energy usage* (Production and Facilities based on 1999)

\section{Cement Industry}

Facilities

\section{Produced (tonnes/yr)}

Cement

United States

$8.60 \mathrm{E}+07$

World

$1.60 \mathrm{E}+09$

INPUTS (tonnes/day)

Raw Materials (Limestone, Clay, and Shale)

$3.92 \mathrm{E}+05$

(26\% used for wet process kilns; $74 \%$ used for dry process kilns)

OUTPUTS (tonnes/day)

Cement (United States)

$2.35 \mathrm{E}+05$

\section{UTILITIES}

Fuel (TJ/day)

$1.10 \mathrm{E}+03$

Avg. Fuel Consumption (TJ/day)

$9.37 \mathrm{E}+00$

Electricity (MW)

$1.61 \mathrm{E}+03$

Avg. Electricity Consumption (MW)

$1.37 \mathrm{E}+01$

\section{EMISSIONS (tonnes/day)}

$\mathrm{CO}_{2}$ Emissions

$4.45 \mathrm{E}+05$

*Worrell, E., Galitsky, C., "Energy Efficiency Improvement and Cost Saving Opportunities for Cement Making," LBNL-54036-Rev, 2008 


\section{Appendix $O$ Potash, Soda, and Borate Mining}

Potash, borates and soda ash are industrial minerals, primarily used as feedstocks for other industries.

\subsection{Potash}

Potash refers to a variety of mined and manufactured salts, containing the elemental potassium in water-soluble form. Potash historically refers to potassium carbonate (recovered in iron pots from leaching wood "ashes" with water [DOE-EERE 2012]). In 1997 the United States produced 2.9 million tonnes ( $\sim 1.4$ million tonnes in $\mathrm{K}_{2} \mathrm{O}$ Eq.) at six facilities with average $\mathrm{CO}_{2}$ emission of 467 tonnes a year per facility (based on $\mathrm{CO}_{2}$ emission at rates of $0.002 \mathrm{~kg} / \mathrm{kg} \mathrm{K} 2 \mathrm{O}$ ). The electricity and heat requirement for this industry is very low compared to other industries that have been studied. Thus, this industry will not be discussed further.

\subsection{Borates}

Boron containing minerals are referred to as borates. The three most common minerals that serve as a source of borates are: borax (tincal) and kernite, which are sodium borates; ulexite, a sodium-calcium borate; and colemanite, a calcium borate. Borates are essential for imparting strength, durability, heat, and impact resistance to glass and glass fibers. In 2000 the U.S. produced 1.1 million tonnes of borates (DOE-EERE 2012), which was reduced to 536,000 tonnes in 2003. The energy consumption and emission rates are hard to decipher from the literature because of the minimal production of borates and thus will not be discussed further

\subsection{Soda Ash}

The term soda ash is used for sodium carbonate $\left(\mathrm{Na}_{2} \mathrm{CO}_{3}\right)$, a chemical refined from trona or sodium sesquicarbonate $\left(\mathrm{Na}_{2} \mathrm{CO}_{3} . \mathrm{NaHCO}_{3} .2 \mathrm{H}_{2} \mathrm{O}\right)$ and from sodium carbonate bearing brines (using the Solvay process). In 2011, the United States produced 10.7 million tonnes of soda ash, increasing to 11.7 million tonnes in 2015. Most of the soda ash is produced using trona; thus, more details are provided on this process. The following energy summary (Figure M-1) and energy breakdown with emissions (Table M-1), are based on a facility producing 4 million tons per year. This scale corresponds to each of the four plants near Green River, Wyoming. Each plant uses an estimated total of $625 \mathrm{MW}_{\text {th }}(54 \mathrm{TJ} /$ day $)$ of heat. Using this case study, energy requirements for each individual process can be broken down with the net water requirement and $\mathrm{CO}_{2}$ emissions. Figure $\mathrm{M}-1$ and $\mathrm{M}-2$ provides a summary of the material and energy flow for a nominal size soda ash plant and process flow diagram for the production of soda ash from trona, respectively. Table M-1, provides the net energy consumption for each individual process for production of soda ash. 


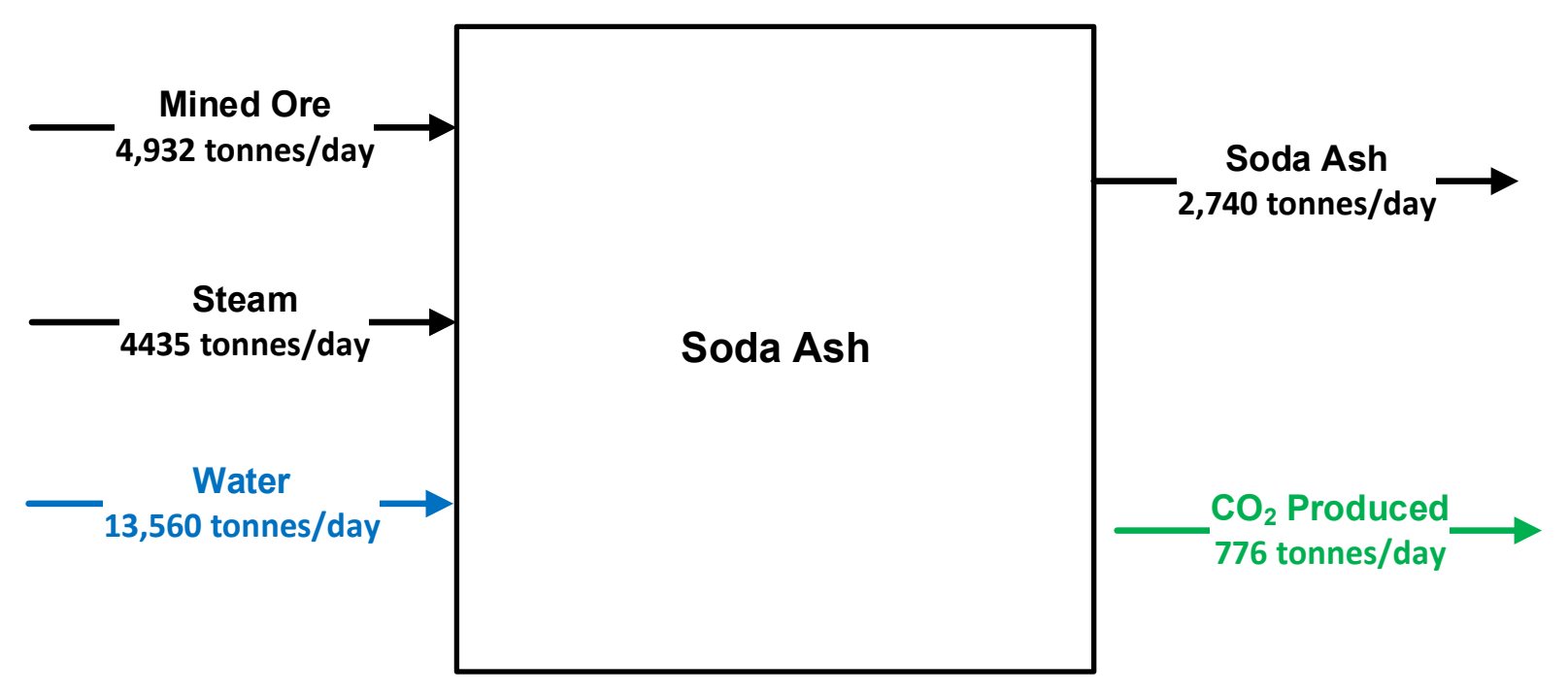

Figure 0-1. Material and energy flows for a nominal Soda Ash (processing from Trona) production plant.

\subsection{Process and Description}

Soda Ash Mining: Variety of mining methods are used in soda mining, such as room-and-pillar mining, conventional mining, continuous mining, and solution mining.

Crushing and Calcination: After mining and crushing, the trona ore is calcined in rotary gasfired calciners operating at $150-300^{\circ} \mathrm{C}$. Calcination process removes water and carbon dioxide from the ore, leaving behind mainly sodium carbonate (soda ash) and insoluble compounds.

Dissolving, Settling, Filtration, and Crystallization: Sodium carbonate is dissolved in water, such that insoluble clays and iron compounds could be physically separated from the sodium carbonate solution. Further, organic contaminants in trona are adsorbed onto activated carbon beds prior to the crystallization process, such that organics do not interfere with the crystal growth rate.

Drying: The crystals are further sent to hydrocylones and are dewatered in centrifuges, after which they are fed to steam tube dryers. Crystals are dehydrated into dense soda ash and are then sent to storage or shipment. 


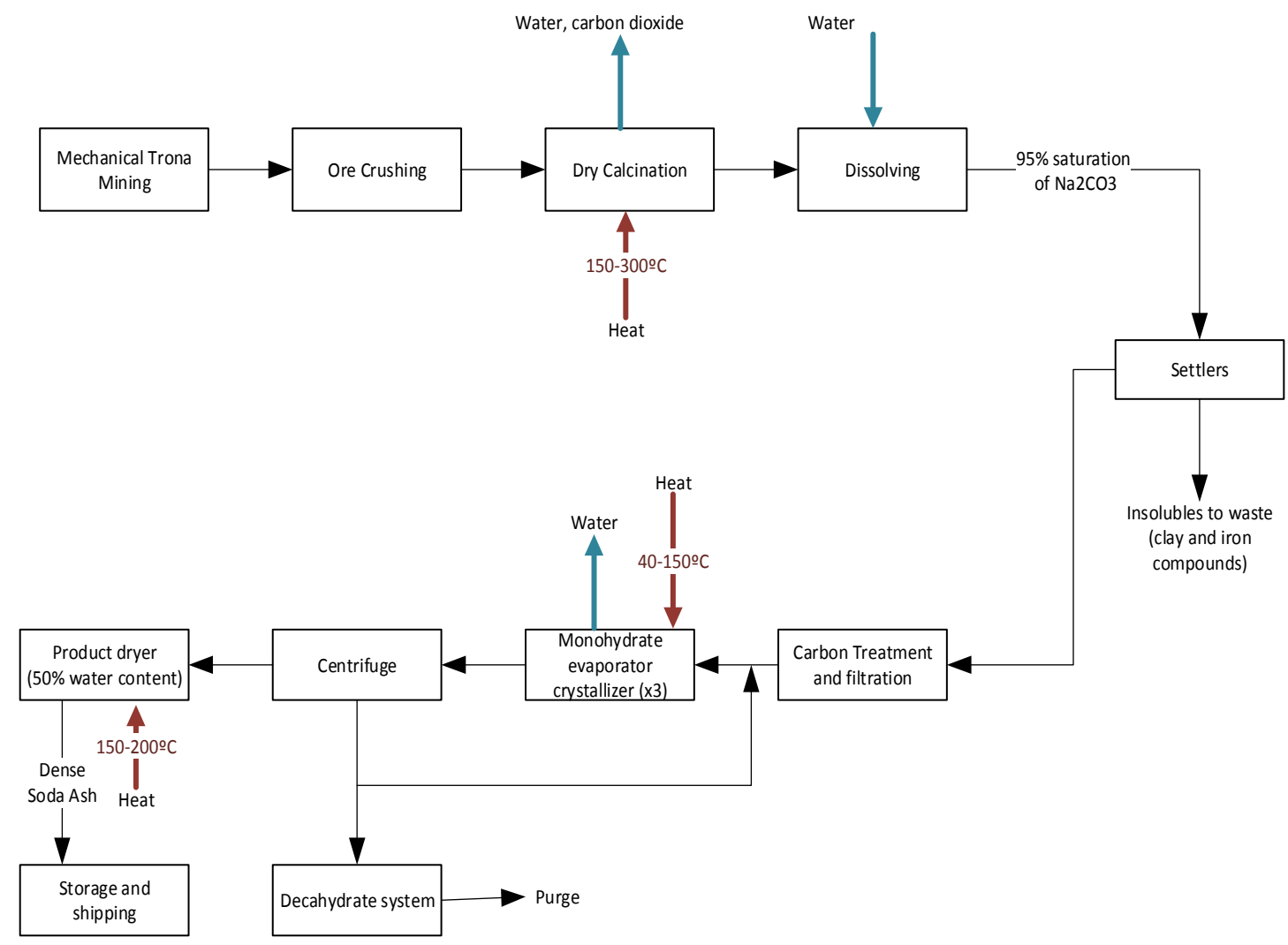

Figure 0-2. Process flow for trona $\left(\mathrm{Na}_{2} \mathrm{CO}_{3} \cdot \mathrm{NaHCO}_{3} .2 \mathrm{H}_{2} \mathrm{O}\right)$ processing to produce soda ash $\left(\mathrm{Na}_{2} \mathrm{CO}_{3}\right)$. 
Table 0-1. Energy consumption breakdown for soda ash production process from trona.

\begin{tabular}{|lcc|}
\hline & Soda Ash (Trona) Process Results & \\
Facilities (Green River, WY) & & 4 \\
Heat Requirement (TJ/day) & & 54 \\
Inputs & Mined Ore (tonnes/day) & 19,726 \\
Outputs & Soda Ash (tonnes/day) & 10,959 \\
& & \\
Utility Summary & Dry Calcination (TJ/day) & 14.5 \\
& Crystallizer (TJ/day) & 12 \\
& Product Dryer (TJ/day) & 27.6 \\
Water (tonnes/day) & Dry Calcination Process & 4,088 \\
& Dissolving & 25,078 \\
& Crystallizer & 14,119 \\
& Product dryer & 10,959 \\
& Total Water Consumption (tonnes/day) & 54,243 \\
& & \\
$\mathrm{CO}_{2}$ Emissions & Emitted (tonnes/day) & 3,105 \\
\hline
\end{tabular}

